\title{
Dybdeboringen
}

\section{Nøvling nr. 1 i Midtjylland}

The deep test well Nøvling No. 1 in Central Jutland, Denmark

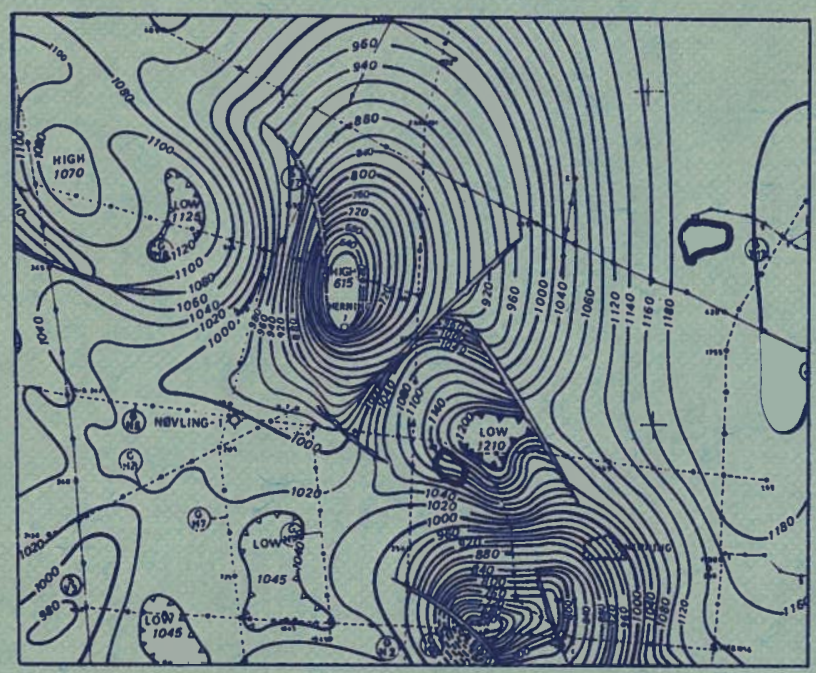

I kommission hos C. A. Reitzels Forlag . København 1973 
DANMARKS GEOLOGISKE UNDERSØGELSE

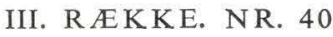

Geological Survey of Denmark. III. Series. No. 40

\section{Dybdeboringen}

Nøvling nr. 1 i Midtjylland

Resultaterne af de geologiske undersøgelser

$$
\text { Af }
$$

Leif Banke Rasmussen, J. C. Baartman,

Svend E. Henriksen, Finn Nyhuus Kristoffersen, Arne Dinesen, Inger Bang, Erik Stenestad, Arne Buch, Ole Bruun Christensen, Olaf Michelsen, Torben Juul Hansen og Fritz Lyngsie Jacobsen

Red. af Leif Banke Rasmussen

English summaries

The deep test well Nøvling No. 1 in Central Jutland, Denmark

The results of the geological investigations

I kommission hos

C. A. REITZELS FORLAG

KØBENHAVN 1973 
D. G. U. III. rk. nr. 40

»Dybdeboringen Nøvling nr. 1 i Midtjylland «

er sat med Monotype Times og trykt i 2000 eksemplarer hos Andelsbogtrykkeriet i Odense.

Klicheerne er udført af Tutein \& Koch.

Papiret er ekstraglittet 262, $125 \mathrm{~g}$ fra a/s De forenede Papirfabrikker.

ISBN 8742106257

Med 8 tavler samt 1 bilag i lomme

With 8 plates and 1 separate well-log 


\section{INDHOLD}

\section{CONTENTS}

Side

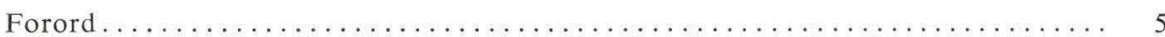

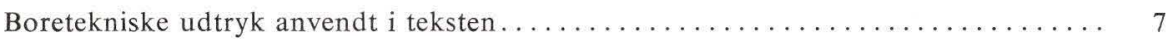

Leif Banke Rasmussen: Nøvling nr. 1. Oversigt over boringens historie og geologiske

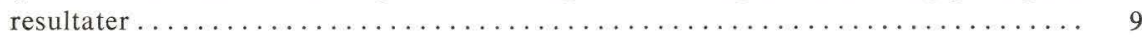

Novling No. 1. Summary of the history of the boring and the geological results.... 23

J. C. Baartman: Interpretation of reflection seismic work in the area around Novling No. 134 Fortolkning af reflektionsseismiske arbejder i området omkring Nøvling nr. 1 . . 49

Svend E. Henriksen: Bestemmelse af borehulsafvigelser, laghældninger og temperatur-

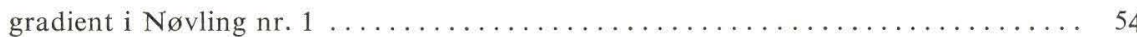
Determination of deviations, dips, and temperature gradient of Novling No. $1 \ldots \ldots 60$

Finn Nyhuus Kristoffersen: Oligocæn og miocæn i Nøvling nr. $1(0-312 \mathrm{~m})$. Biostratigrafisk undersøgelse på grundlag af foraminiferer . . . . . . . . . . . 63 Oligocene and Miocene in Novling No. 1. A biostratigraphical study on the basis of

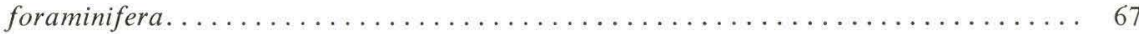

Arne Dinesen: Eocæn i Nøvling nr. $1(312-427$ m) . . . . . . . . . . . . 71

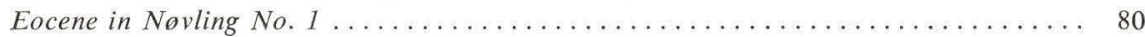

Inger Bang: Paleocæn i Nøvling nr. $1(427-640 \mathrm{~m}) \ldots \ldots \ldots \ldots \ldots \ldots \ldots \ldots \ldots$

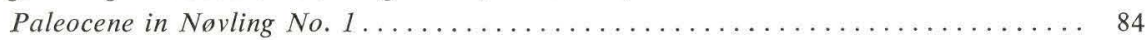

Erik Stenestad: Øvre kridt i Nøvling nr. $1(640-1329 \mathrm{~m}) \ldots \ldots \ldots \ldots \ldots \ldots \ldots \ldots . \ldots 6$

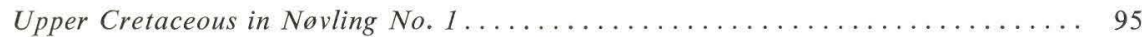

Arne Buch: Marint nedre kridt i Nøvling nr. $1(1329-(1483 \mathrm{~m})) \ldots \ldots \ldots \ldots \ldots \ldots \ldots$ Lower Cretaceous in Novling No. 1. Biostratigraphy based upon foraminifera..... 110

Ole Bruun Christensen: De nedre kretaciske og øvre jurassiske formationer og ostracodfaunaer i Nøvling nr. $1(1329-1509 \mathrm{~m}) \ldots \ldots \ldots \ldots \ldots \ldots \ldots \ldots \ldots \ldots \ldots \ldots \ldots$ The Lower Cretaceous and Upper Jurassic formations and ostracod faunas in Novling

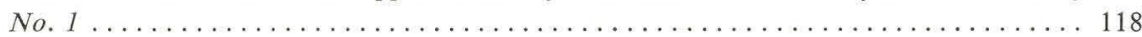

Inger Bang: Jura-biostratigrafi i Nøvling nr. 1 på grundlag af foraminiferer. . . . . . 119 Biostratigraphy of the Jurassic deposits in Novling No. 1 based on foraminifera... 122 Olaf Michelsen: Nedre jura i Nøvling nr. 1 (1509-1847 m). Biostratigrafi baseret

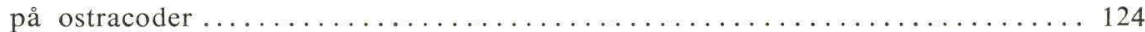
Lower Jurassic in Novling No. 1. Biostratigraphy on the basis of ostracods...... 130

Ole Bruun Christensen: Vinding formationen (øvre trias) i Nøvling nr. $1 \ldots \ldots \ldots 132$ The Vinding Formation (Upper Triassic) in Novling No. 1.............. 135

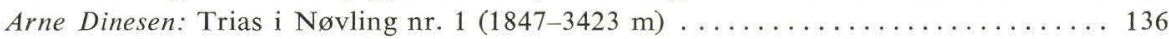
Lithology of the Triassic section in Novling No. $1 \ldots \ldots \ldots \ldots \ldots \ldots \ldots \ldots \ldots \ldots$

Fritz Lyngsie Jacobsen: Zechstein i Nøvling nr. 1 (3423-3534 m). Lithologisk be-

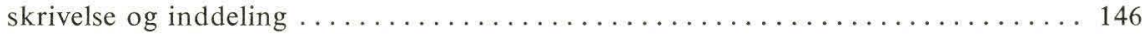

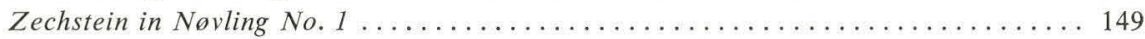

Ole Bruun Christensen: Rønde og Nøvling formationerne (silur) i Nøvling nr. 1

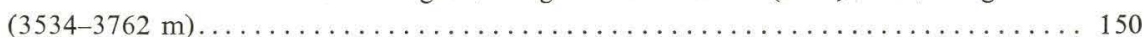
The Ronde and Novling Formations (Silurian) in Novling No. 1............ 156

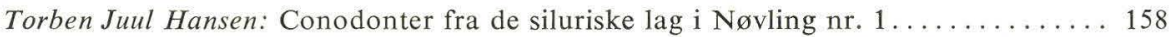
Conodonts from the Silurian of Novling No. $1 \ldots \ldots \ldots \ldots \ldots \ldots \ldots \ldots \ldots \ldots \ldots \ldots$

Fritz Lyngsie Jacobsen: Vulkaniterne i de præ-permiske lag i Nøvling nr. $1 \ldots \ldots \ldots 162$ The volcanites in the Pre-Permian beds of Novling No. $1 \ldots \ldots \ldots \ldots \ldots \ldots \ldots \ldots 163$

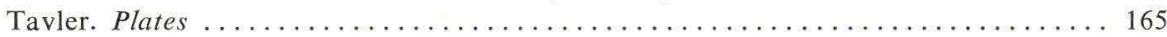




\begin{abstract}
The book contains geological and geophysical reports on the deep test well Nøvling No. 1. This boring was made by "Dansk Undergrunds Consortium" in Central Jutland 1966.

Beds of Pleistocene, Tertiary, Upper Cretaceous, Lower Cretaceous, Jurassic, Triassic, Upper Permian and Upper Silurian age were penetrated. The final depth of the boring was 12342' or 3762 m below the Kelly Bushing.

The book includes 17 articles written by 12 authors, all of whom are (or were) from the staff of the Pre-Quaternary Department (= Dep. of Subsurface Geology) of the Geological Survey of Denmark.

In an introductory article a review is given of the geological and structural aspects of the boring together with an outline of the technical and administrative data.
\end{abstract}




\section{F,O'RORD}

Den bog, som hermed foreligger om Dansk Undergrunds Consortiums dybdeboring Nøvling nr. 1, er den anden i rækken af geologiske rapporter om de nyere dybdeboringer. Den følger stort set samme plan som bogen om Rønde nr. 1, der kom i 1971, men betegner i forhold til denne en udvidelse af emnekredsen, idet omtalen af de geofysiske og strukturelle forhold i boringens omegn har fået plads i en speciel artikel.

Efter ansættelsen af den hollandske geofysiker J. C. BAARTMAN her i afdelingen pr. 1. april 1972 er det blevet muligt at tage fortolkningen af de mange foreliggende seismiske data op til behandling. Hr. BAARTMAN har til nærværende bog bearbejdet disse data fra området omkring Nøvling, hvilket har sat de geologiske resultater i relief i mere end én henseende.

En anden nydannelse i forhold til Rønde bogen er udvidelsen af billedmaterialet $\mathrm{i}$ form af fossiltavler. Flere af de biostratigrafiske resultater, som omtales i artiklerne, beror på upublicerede iagttagelser, der ofte er gjort i anden forbindelse. Fossiltavlerne er da tænkt som en foreløbig illustration af forhold, der ellers ville kræve lange beskrivelser, eller endog specialafhandlinger, som forudsætning for forståelsen.

Forberedelsen af denne bog har taget længere tid end forudset. De 12 forfattere, der alle er (eller har været) ansat i DGU's prækvartærafdeling, har haft ulige vilkår at arbejde under. Fra visse afsnit af boringen har fossilmaterialet været af væsentlig ringere beskaffenhed end i andre intervaller. De fleste geologer har tillige haft andre opgaver at varetage sideløbende med bearbejdelsen af Nøvling boringen, ligesom personlige forhold også har spillet ind.

Det kan ikke nægtes, at artiklerne fremtræder noget heterogene, men vi har foretrukket at lade de enkelte bidragydere forelægge deres resultater individuelt. Det af TORBen JuUl Hansen forfattede afsnit er en gengivelse af en intern rapport fra tiden kort efter boringens fuldførelse. Rapporten har kun været underkastet redaktionelle korrektioner og medtages i bogen med tilladelse af forfatteren, der overtog en stilling udenfor instituttet i 1967.

Ved afslutningen af arbejdet med Nøvling bogen ønsker jeg ikke alene at takke de 11 medforfattere, men også den øvrige stab i prækvartærafdelingen, der har bidraget med deres arbejde til bogens udarbejdelse.

Maskinskrivningen af manuskripterne er foretaget af KIRSTEN SPERLING og Vibeke Hermansen. Tegningerne er udført af Jette ØrnbJerg Jensen, Helle Christensen, Kirsten Andersen og Inge Martin-Legène. Fotoarbejdet skyl- 
des O. NeERgaArd Rasmussen, og oversættelsesarbejdet er foretaget af Svend E. Henriksen. God hjælp med redaktionsarbejdet er ydet mig af OlaF MiChELSEN. Alle disse medarbejdere skylder vi en særlig tak for det omhyggelige arbejde, de har udført.

København, d. 20. februar 1973. 


\title{
BORETEKNISKE UDTRYK ANVENDT I TEKSTEN
}

\author{
boremudder - en opslæmning, der gør det muligt at bore uden fore- \\ rør og at bringe det løsborede materiale op til jord- \\ overfladen. \\ caving - nedfald af materiale fra borehullets væg. \\ circulation - opretholdelse af mudderstrømmen under midlertidig \\ afbrydelse af rotationen for at opretholde viskositeten \\ af boremudderet, så borehullet ikke skrider sammen. \\ continuous dipmeter - hældningsindikator. \\ core - borekærne. \\ cuttings - friborede spåner eller partikler af bjergarten. \\ drift indicator - instrument til måling af afvigelser i borehullets retning. \\ gamma ray log \\ (= gammastråle log) - registrering af bjergartens naturlige radioaktivitet \\ (gammastråling). \\ junk basket $\quad-$ redskab til opsamling af tabt materiale fra borehullets \\ bund. \\ kelly - øverste del af borestammen, der forbinder mudder- \\ slangen med borerørene. \\ kelly bushing \\ (fork. KB) \\ - bøsning omkring kelly'en. Overfører drivkraften fra \\ drejeskiven til borestammen. \\ lag distance $\quad-$ afstanden mellem sand dybde og tilsyneladende dybde. \\ lag time - - den tidsfaktor, som indgår i beregning af prøvedybden, \\ dvs. tiden fra borets nedbrydning af bjergarten til \\ materialets tilsynekomst ved jordoverfladen. \\ laterolog - registrering af den sande modstand i bjergarten, særligt \\ i tynde lag og med samtidig anvendelse af boremudder \\ med stor ledningsevne. \\ $\log \quad$ - registrering af måleresultater. \\ microlaterolog - registrering af den effektive porøsitet i bjergarten. \\ mudderkage - koaguleret boremudder på borehullets væg. \\ neutron log - registrering af bjergartens totale porøsitet. \\ rotary table $\quad-$ drejeskive (i plan med boreplatformen). \\ sidewall sample $\quad$ - kærneprøve udtaget af borehullets væg ved hjælp af \\ et specielt instrument.
}


sonic log

(= lydhastigheds $\log )$ - registrering til bestemmelse af porøsitet $\mathrm{i}$ reservoirbjergarter.

whipstock - afbøjningsredskab.

For en almindelig orientering om tekniken ved olieboring henvises til de relevante læreeller håndbøger $\mathrm{i}$ oliegeologi og olieeftersøgningsmetodik, bl.a. kan anbefales

Sylvain J. Prrson: Handbook of well log analysis. Prentice-Hall, Inc. Englewood Cliffs, N.-J. 1963.

Leroy: Subsurface Geologic Methods. Colorado School of Mines. Sidste udgave. 


\section{NØVLING NR. 1 \\ OVERSIGT OVER BORINGENS HISTORIE OG GEOLOGISKE RESULTATER}

af

Leif Banke Rasmussen

\section{Boringens udforelsestid}

Dybdeboringen »Nøvling nr. 1 « blev påbegyndt d. 13. september 1966 og afsluttedes d. 15. november samme år. Borehullet blev lukket d. 25. november 1966, efter at der var blevet foretaget forskellige petrofysiske undersøgelser (Schlumberger målinger), hvorefter boreudstyret blev flyttet til Mors.

Boringens nr. i DGU's borearkiv er 84.1777.

\section{Boringens beliggenhed}

Borestedet lå på en mark tæt sydvest for gården Egbæk og ca. 1,7 km sydvest for Nøvling Kirke på Geodætisk Instituts målebordsblad M 2405 eller 1114 I NØ (se kortudsnittet fig. 1, side 10). Nøvling Kirke ligger ca. 8 km NV for Herning. De geografiske koordinater på borestedet er $8^{\circ} 48^{\prime} 36^{\prime \prime} \varnothing$ og $56^{\circ} 10^{\prime}$ $09^{\prime \prime} \mathrm{N}$, målt i forhold til Greenwich.

\section{Boringens administration}

Boringen blev udført af DANSK UNDERGRUNDS CONSORTIUM (forkortet DUC), som bl.a. omfatter firmaet A. P. MøLLER, der er indehaver af eneretsbevillingen til efterforskning og indvinding af kulbrinter, og som stod for afleveringen af det materiale, der ifølge eneretsbevillingen tilkom staten.

Eksplorationsarbejderne blev varetaget af Gulf Oil Company of DenMark, der havde en geolog udstationeret ved boringen: Mr. Robert K. Kirkbride, som også under denne boring var til god hjælp for DGU's geolog på borestedet.

Indsamlingen af tekniske data og udtagelsen af boreprøver blev foretaget af personale fra firmaet Formation Logging Service Co. (Peters Logging S.A.), med hvilket DGU's udstationerede geolog ligeledes var i daglig kontakt, og fra hvem der blev modtaget kopier af diagrammerne, hvorpå de tekniske data var anført.

Petrofysiske målinger i borehullet blev udført af firmaet SCHLUMBERGER ved 


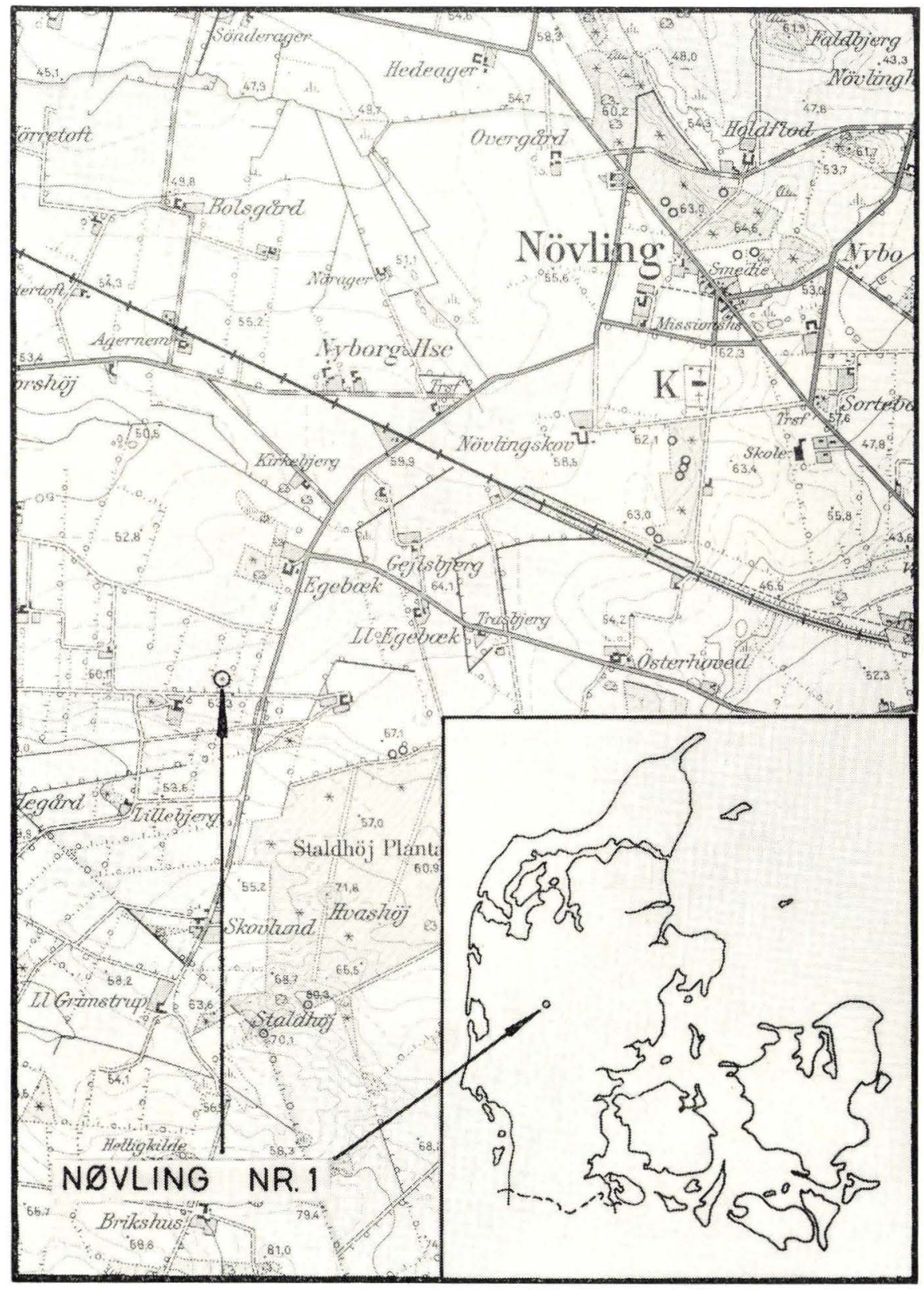

Fig. 1. Beliggenhed af boringen Nøvling nr. 1, vist på udsnit af Geodætisk Instituts $4 \mathrm{~cm}$ kort 1114 I NØ og på miniaturkort over Danmark.

(Autoriseret reproduktion)

Situation of the boring Novling No. 1 . 
visse lejligheder. Disse borehuls-undersøgelser (Schlumberger logs) omfatter en række målinger af betydning for bedømmelsen af borehullets diameter på ethvert givet sted, hullets hældning etc., foruden de vigtige undersøgelser af de gennemborede lags fysiske forhold og deres nøjagtige beliggenhed. Oplysninger om målingernes art, intervaller etc., fremgår af det af ARNE DINESEN udarbejdede tekniske oversigtsdiagram fig. 2, side 12 .

Borearbejdet udførtes af firmaet Reading \& Bates Offshore Drilling Co. med et boretårn af typen »Oilwell $940 \mathrm{E} \ll$.

\section{Boremetode}

Boringen udførtes som rotationsboring, og der blev kun kærneboret i 4 intervaller, nemlig 11555'-11612' (kærne nr. 1), 11614'-11676' (kærne nr. 2), 11896'$11932^{\prime}$ (kærne nr. 3) og 12311'-12342' (kærne nr. 4). Prøverne fra de øvrige boreafsnit foreligger i form af ialt 780 skylleprøver, som udgør grundlaget for de lithologiske og biostratigrafiske undersøgelser.

\section{Rordiametre}

Efter at et såkaldt styrerør (conductor pipe) var ført ned til 15' (4,6 m) dybde, boredes med 26" borekrone ned til 518' (158 m). Hullet udforedes dernæst

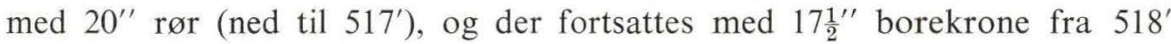
$(158 \mathrm{~m})$ til $3510^{\prime}(1070 \mathrm{~m})$. Efter en ny udforing med $13 \frac{33^{\prime \prime}}{8}$ rø (ned til 3509') boredes videre fra $3510^{\prime}(1070 \mathrm{~m})$ til $11555^{\prime}(3522 \mathrm{~m})$ med $12 \frac{1^{\prime \prime}}{4}$ borekrone. Fra sidstnævnte dybde til slutdybden $12342^{\prime}$ (3762 m) anvendtes $8 \frac{7}{16}{ }^{\prime \prime}$ kærneborekrone vekslende med $8 \frac{1}{2}^{\prime \prime}$ almindelig borekrone. Umiddelbart efter at kærne nr. $1\left(11555^{\prime}-11612^{\prime}\right)$ var taget op, nedførtes et $9 \frac{5}{8}{ }^{\prime \prime}$ foringsrør til $11582^{\prime}(3530 \mathrm{~m})$. Det bemærkes, at $9 \frac{5^{\prime \prime}}{8}$ foringen ikke er vist på det skematiske snit gennem boringen i det tekniske oversigtsdiagram fig. 2, side 12 .

Ikke blot med hensyn til boringens diametre, men også hvad angår alle andre tekniske forhold henvises iøvrigt til det nævnte oversigtsdiagram, som er udarbejdet af ARne DiNESEN.

\section{Prøveudtagning}

Under borearbejdet blev der i begyndelsen udtaget skylleprøver for hver 30', senere for hver $10^{\prime}$, idet der dog i visse intervaller blev taget prøver enten for hver $15^{\prime}$ eller for hver 20', se nærmere på fig. 2.

\section{Dybdeangivelser}

Dybdetallene kræver særlig opmærksomhed, da alle dybder, som blev målt af boreentreprenøren, var angivet $\mathrm{i}$ engelske fod under »Kelly Bushing « (forkortet KB), medens dybderne på Schlumberger diagrammerne var angivet i meter 


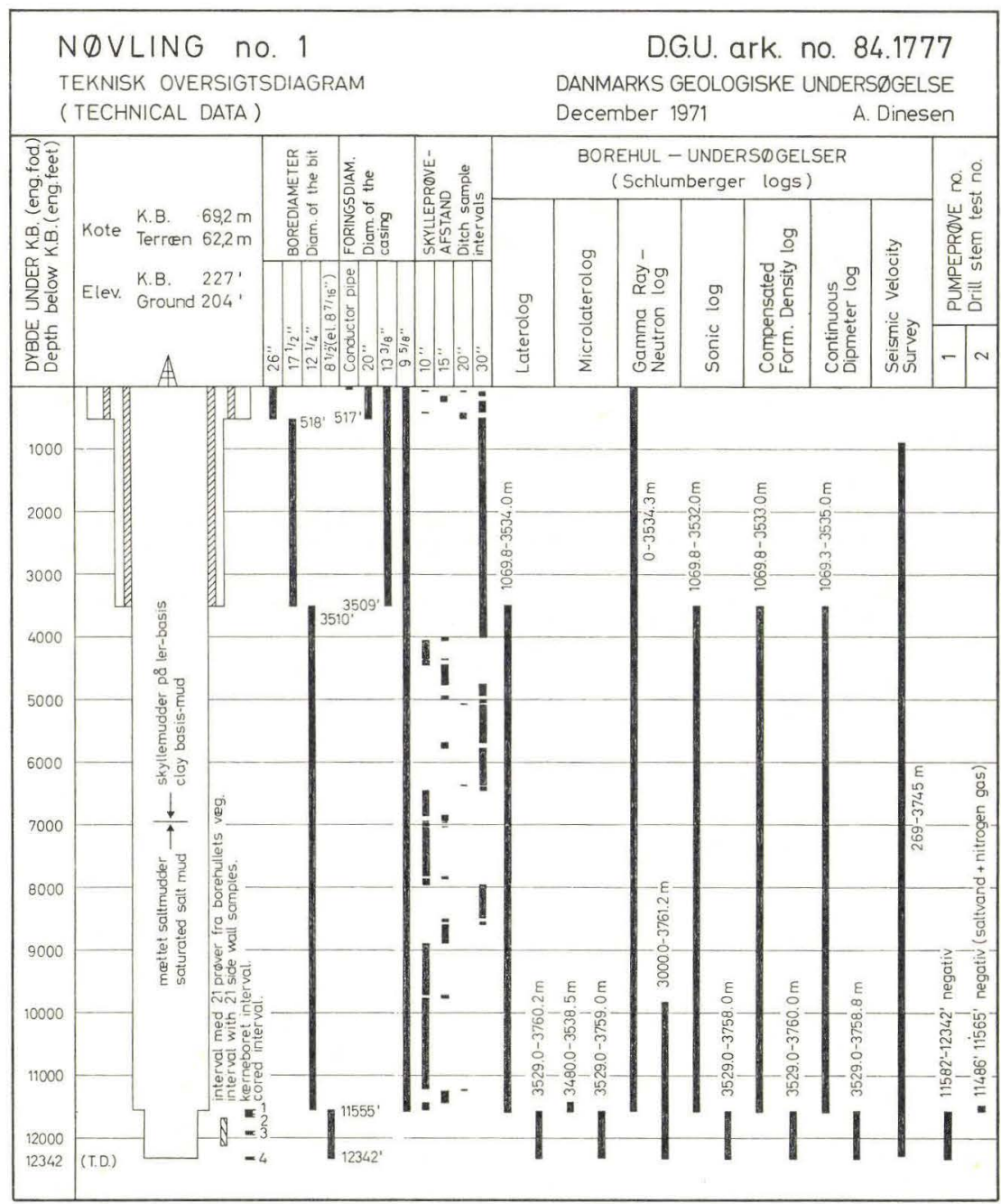

Fig. 2

under KB. Ydermere er det ofte nødvendigt at korrigere dybdetallene for forsinkelse og at tage hensyn til afbøjning af borehullet som skildret nedenfor.

Da problematikken omkring dybdetallene er fuldstændig den samme som for dybdeboringen ved Rønde, aftrykkes her in toto, hvad der anførtes side 13 i beretningen om denne boring:

I de forskellige biostratigrafiske og lithologiske afsnit i nærværende bog, er alle dybdeangivelser $\mathrm{i}$ engelske fod $\mathrm{i}$ overensstemmelse med boreentreprenørens angivelser, men i visse tilfælde, hvor det har været nødvendigt at støtte den lithologiske beskrivelse af lagene væsentligt på grundlag af Schlumberger målingerne, er der primært regnet med dybder i meter under KB. Det har i denne 
forbindelse været hensigtsmæssigt at omregne disse dybdeangivelser til engelske fod. Sådanne omregnede dybdeangivelser er anført i teksten med kursiv.

De oprindelige angivelser i engelske fod under KB udgør altså det originale sæt dybdeangivelser, som alle prøverne er forsynet med. Skal man tilbage i DGU's prøvemagasiner eller i samlingerne af mikrofossil-slides finder man således den ønskede prøve eller slide under sin oprindelige dybdeangivelse i engelske fod under KB.

Denne dybde er imidlertid ikke nøjagtig, da der er to forhold, som prøveudtageren og etiketteskriveren ikke har kunnet tage hensyn til, og som kort skal omtales her, nemlig skylleprøvernes forsinkelse og borehullets afbøjning:

1) Forsinkelse af skylleprøverne. Inden de løstborede jordlag når op til jordoverfladen har de måttet tilbagelægge en lang strækning, der selvfølgelig afhænger af boringens dybde. Ad denne transportvej forsinkes materialet i færre eller flere minutter, således at den dybde, hvor prøvematerialet er boret løs, forlængst er passeret, når det når op til jordoverfladen. Prøvetageren har imidlertid kun mulighed for at forsyne prøveposen med de tal, der viser dybden, som den nederste ende af borestammen med skærehovedet befinder sig i. Denne forsinkelse i tid (den såkaldte »lag time«) bliver dog målt med visse mellemrum, således at det er muligt at beregne en mere rigtig dybde i forhold til KB. Det vil dog ikke være muligt at bestemme en prøves dybde helt nøjagtigt.

ARNE DINESEN har på fig. 3 fremstillet et diagram, hvor man kan danne sig et skøn over forsinkelsernes størrelsesorden, både hvad angår tid (lag time) og afstand (lag distance).

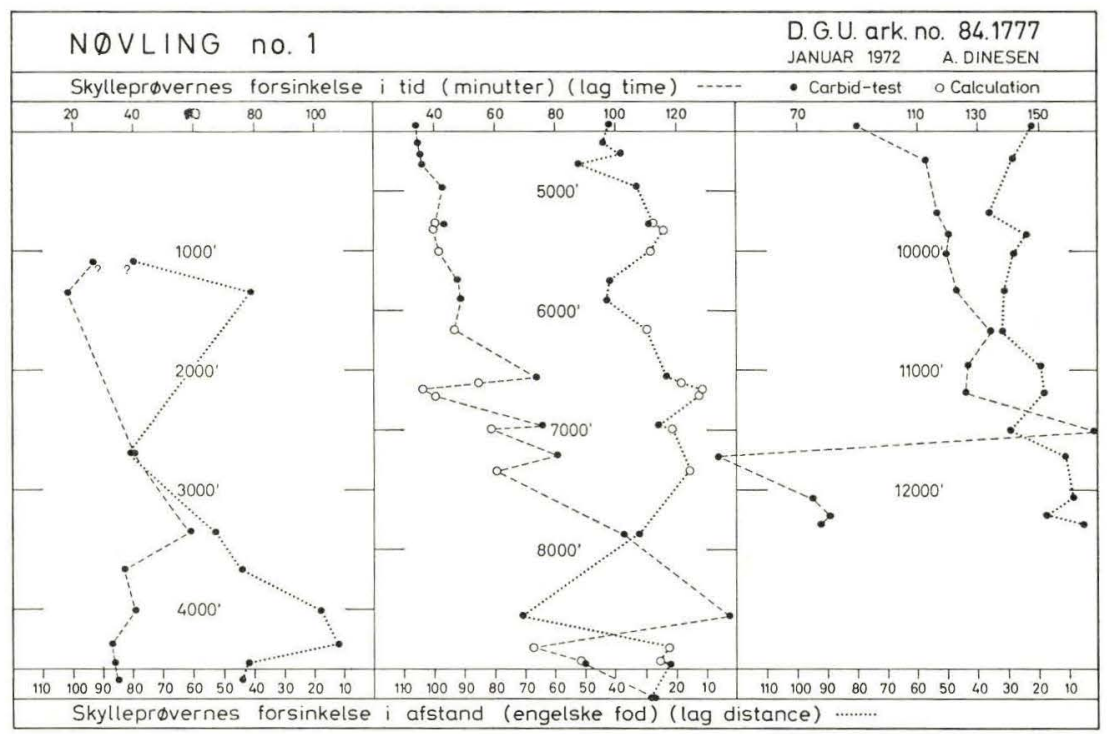

Fig. 3 
2) Afbøjning af borehullet. Retningen af borehullet i en dyb boring er næsten aldrig helt lodret. Der kan være betydelige afvigelser, hvilket selvfølgelig influerer på målingerne af lagenes nøjagtige placering i rummet og $\mathrm{i}$ forhold til havoverfladen. De metoder, som kan anvendes, for at mindske fejlen på dybdemålingerne som følge af borehullets afbøjning er skildret i S. E. HENRIKSEN's artikel side 54 .

\section{DGU's geologer på borestedet og deres arbejdsopgaver}

Der var udstationeret en geolog fra DGU ved boringen i hele perioden fra dens påbegyndelse til dens afslutning. Man havde, som ved Rønde-boringen, etableret sig $\mathrm{i}$ et feltlaboratorium på borestedet. Koordinationen af feltarbejdet blev også ved Nøvling-boringen varetaget af ARNE DINESEN.

Følgende af DGU's geologer har været udstationeret ved boringen.

\begin{tabular}{c|l|c}
$\begin{array}{c}\text { Udstationerings- } \\
\text { interval }\end{array}$ & $\begin{array}{c}\text { Geologernes } \\
\text { navne }\end{array}$ & $\begin{array}{c}\text { Beskrevet litho- } \\
\text { logien i dybde- } \\
\text { interval }\end{array}$ \\
\hline $\begin{array}{c}\text { 13. sept.-14. okt. } \\
\text { 14. okt. -18. nov. }\end{array}$ & $\begin{array}{l}\text { Olaf Michelsen } \\
\text { Torben Juul Hansen } \\
\text { 18. nov. -22. nov. }\end{array}$ & $\begin{array}{c}0^{\prime}-9680^{\prime} \\
9680^{\prime}-12.342^{\prime}\end{array}$ \\
\hline
\end{tabular}

De udstationerede geologers arbejde omfattede to hovedopgaver: 1) Man skulle nøje følge den tekniske del af borearbejdet, især med hensyn til det, der foregik i og med borehullet og 2) der skulle foretages en omhyggelig undersøgelse af boreprøverne, ligesom disse skulle nedpakkes og indsendes til DGU. Desuden var det geologernes opgave at holde sig i stadig kontakt med Undergrundskonsortiets geologer og entreprenører på borestedet og søge oplysninger om de nærmest forestående operationer samt indhente forklaringer på de tekniske spørgsmål, der ofte dukkede op under borearbejdets fremadskriden.

Det påhvilede de udstationerede geologer at indsende følgende materiale til DGU:

1. Beskrivelse af alle optagne prøver: skylle- og mejselprøver, samt kærneprøver.

2. En geologisk vurdering af den gennemborede lagserie, således som den tog sig ud på borestedet i den aktuelle situation (en såkaldt geologjournal).

3. Alle tekniske data, herunder boretidsmålinger, dybde for udskiftning af borekærner, disses type, målinger af borehullets hældning i forhold til lodlinien, anbringelse af forerør, rørdiameter etc.

4. Alle modtagne boreprøver og andet materiale vedr. boringen.

Derudover var der meget ofte telefonisk kontakt med prækvartærafdelingen, for at man på DGU daglig kunne være nogenlunde à jour med boringen. 


\section{Arbejdet i DGU's laboratorier}

Som det var tilfældet under Rønde-boringen blev de udtagne prøver også for denne borings vedkommende undersøgt for mikrofauna sideløbende med undersøgelserne på borestedet. Disse undersøgelser foretoges i DGU's prækvartærafdeling og udgjorde grundlaget for en foreløbig biostratigrafisk og chronostratigrafisk inddeling af den gennemborede lagserie. De fleste af disse tidlige undersøgelser foretoges af ARNE BUCH og ERIK STENESTAD.

En række af prækvartærafdelingens geologer har senere haft prøverne fra hver deres tidsenhed til bearbejdelse, idet man har benyttet sig af de pågældendes specialviden for at nå et hurtigt overblik. Fordelingen har været den, som fremgår af de enkelte bidrag til nærværende bog.

Biostratigrafiske oversigter baseret på foraminiferundersøgelser blev under borearbejdet udarbejdet af ARNE BUCH.

Foreløbige undersøgelser af sedimenter og fossilindhold i borekærne 1-4 blev foretaget af OLE BRUUn CHRISTENSEN straks efter kærnernes ankomst til København. De af ham udarbejdede rapporter er senere udgivet i svagt ændret form (se CHRISTENSEN 1971).

\section{Geologiske hovedtrak $i$ Nøvling-profilet}

Det betydeligste geologiske resultat af denne boring var påvisningen af øvre siluriske aflejringer direkte under lag fra zechstein. Allerede under boringen blev det af Ole BruUn Christensen konstateret, at lagene under zechstein-evaporitterne indeholder fossiler af øvre silurisk alder. I den dybest liggende skifrede lersten lykkedes det ham at finde Colonograptus colonus, og i den overliggende finsandsten fandtes rester af brachiopoder, ostracoder, pelecypoder, gastropoder, ortoceratiter, tentaculiter, conodonter, conularider, crinoider, koraller og trilobiter.

De rødlige affejringer mindede på forhånd om de lag, der forekommer i den skånske Öved-Ramsåsa serie. Under et besøg på de skånske lokaliteter sammen med Bruun Christensen og T. Juul Hansen i marts 1967 havde jeg lejlighed til at få dette bekræftet. Her fandt vi en stor lighed mellem sedimenterne ved Nøvling og lagene på typelokaliteten ved Ramsåsa. Selvom denne lokalitet er et forlængst opgivet og nu delvis med affald fyldt brud, hvis skrænter desuden er noget bevokset med træer og buskads, lykkedes det dog at finde ret gode blotninger og ved gravning at finde fossilførende siluriske lag. Ligheden med Nøvling lagene er slående.

Et ret overraskende fund var de basaltlag, som blev påvist i silurserien ved Nøvling. Man har ikke tidligere påvist sikker vulkansk aktivitet i øvre silur i Nordeuropa, men i den caledoniske bjergkædefoldnings slutfase vil det ikke være usandsynligt med vulkanisme, og Nøvling ligger ikke urimelig langt fra det caledoniske strøg. 
Vulkaniterne fra Nøvling har været aldersbestemt efter kalium/argon metoden af OLE LARSEN (1972), der fandt, at de var 276 millioner år gamle ( \pm 12 mill. år), hvilket svarer til permisk alder. Dette forklarer han ved, at vulkaniterne muligvis har mistet radiogent argon engang i perm. Den siluriske alder af de sedimenter, der omgiver vulkaniterne, kan ikke anfægtes.

Mellem silurlagene og permlagene i Nøvling er der en betydelig diskordans og hiatus. Der savnes ethvert spor af lag fra devon, karbon og nedre perm. Formodentlig har området ligget over havets overflade i størstedelen af dette tidsrum. Det har utvivlsomt spillet en stor rolle, at stedet ligger på nordflanken af den store Ringkøbing-Fyn højdestruktur.

Det er også denne placering, der forklarer, at zechstein lagserien i Nøvlingboringen er reduceret til kun at omfatte en ca. $100 \mathrm{~m}$ tyk serie evaporiter. Hvilken af de kendte cykler, denne serie tilhører, er det næppe muligt at fastslå. Foreløbig er der her tale om det eneste kendte zechstein profil på nordflanken af Ringkøbing-Fyn Højderyggen. En tilsvarende reduceret serie er kendt fra Arnum-boringen på strukturens sydflanke.

Overgangen til de overliggende triaslag synes at være ganske jævn og tilsyneladende uden langvarig afbrydelse af sedimentationen. Triasserien ved Nøvling har det samme ensformige præg, som karakteriserer de nordjyske triasprofiler, hvor den fra det syddanske bassin kendte "germanske« tredeling i buntsandstein, muschelkalk og keuper ikke er påviselig, medmindre man tør korrelere det stensaltlag, som ligger omtrent midt i triasserien med visse muschelkalk evaporiter i Syddanmark og Nordtyskland.

Rhæt er her indordnet under triasperioden. Tidsafsnittet er ved Nøvling repræsenteret af såvel marine som limniske aflejringer, og alderen er verificeret ved hjælp af ostracoder (O. BRUUN CHRISTENSEN).

De overliggende jurassiske lag er for nedre juras vedkommende ganske velinddelt takket være velbevarede ostracodfaunaer (OLAF MichelSEN). I modsætning hertil har foraminiferindholdet ikke været velegnet til en biostratigrafisk inddeling af nedre jura serien i Nøvling. Der forekommer mange foraminiferer, og desuden er de velbevarede, men faunaselskaberne er meget sammenblandede i boreprøverne, således at INGER BANG, der har undersøgt dem, ikke har haft mulighed for at fastlægge etage-grænserne nøjagtigt. I skemaet over boringens lagserie side 17-19 er der derfor regnet med den inddeling af nedre jura som undersøgelsen af ostracodfaunaerne har resulteret $i$.

I de øvre jurassiske lag er indholdet af både ostracoder og foraminiferer meget sparsomt. Her er det derfor ret usikkert, hvorledes serien skal inddeles $\mathrm{i}$ etager. Kun synes det sikkert, at kimmeridgien aflejringer er tilstede. Muligvis er også lag fra portlandien repræsenteret.

Overgangen mellem aflejringerne fra jura og nedre kridt er ganske jævn, og det er også biostratigrafisk vanskeligt at afgrænse de to perioder nøjagtigt i Nøvling-boringen. Den nedre kretaciske lagserie iøvrigt består af ret ensformige lag af lersten. De indeholder imidlertid en rig foraminiferfauna, på hvilket 
Oversigt over det gennemborede geologiske profil

\begin{tabular}{|c|c|c|c|c|c|}
\hline \multirow{2}{*}{$\begin{array}{c}\text { Kote } \\
\text { (korrig.) }\end{array}$} & \multirow{2}{*}{$\begin{array}{c}\text { Dybde i } \\
\text { m under } \\
\text { KB }\end{array}$} & \multirow{2}{*}{ Lithologi } & \multicolumn{2}{|c|}{ Chronostratigrafi } & \multirow{2}{*}{$\begin{array}{l}\text { Henvisning til speciel omtale } \\
\text { (forfatter, sidetal) }\end{array}$} \\
\hline & & & Etage & System & \\
\hline \multirow[t]{3}{*}{+69} & 0 & \multirow[t]{2}{*}{ (Kelly Bushing (forkortet K.B)) } & & \multirow[b]{2}{*}{$\begin{array}{l}\text { Kvartær og } \\
\text { tertiær }\end{array}$} & \\
\hline & 7 & & & & \\
\hline & 18 & $\begin{array}{l}\text { Sand vekslende med ler, glimmerholdigt. } \\
\text { Horisonter af brunkul }\end{array}$ & Miocan & \multirow{10}{*}{ Tertiær } & \multirow{2}{*}{ F. Nyhuus Kristoffersen, s. 63} \\
\hline-132 & 201 & \multirow{3}{*}{$\begin{array}{l}\text { Ler, mørkebrunt, glimmerholdigt } \\
\text { Ler, fedt, lyst (Søvind mergel) } \\
\text { Overgangslag mellem fedt, lyst ler og fedt, } \\
\quad \text { grønligt ler (Lillebælt ler) }\end{array}$} & Oligocæn & & \\
\hline-243 & 312 & & \multirow{5}{*}{ Eocæn } & & \multirow{5}{*}{ A. Dinesen, s. 71} \\
\hline-248 & 317 & & & & \\
\hline-283 & 352 & Ler, fedt, grønligt (Lillebælt ler) & & & \\
\hline-296 & 365 & $\begin{array}{l}\text { Overgangslag mellem fedt grønligt ler og } \\
\text { fedt rødbrunt ler (Røsnæs ler) }\end{array}$ & & & \\
\hline-339 & 408 & $\begin{array}{l}\text { Ler, fedt, rødbrunt (Røsnæs ler) og ler, } \\
\text { mørkt, med lag af vulkansk aske }\end{array}$ & & & \\
\hline-358 & 427 & Ler, fedt, gråt, kalkholdigt (Kerteminde ler) & \multirow{2}{*}{ Selandien } & & \multirow{3}{*}{ I. Bang, s. 82} \\
\hline-456 & 525 & Kalk-siltsten, øverst leret & & & \\
\hline-481 & 550 & Kalksten, hvid & Danien & & \\
\hline-571 & 640 & Kalk, hvid (Skrivekridt) m. flint & Maastrichtien & & \\
\hline $\begin{array}{l}-814 \\
-991\end{array}$ & $\begin{array}{r}884 \\
1061\end{array}$ & $\begin{array}{l}\text { Kalksten, hvid til gråhvid, m. lag af } \\
\text { lysegrå mergel } \\
\text { Kalksten, hvid til gråhvid, m. grønliggrå, } \\
\text { glimmerholdig mergel }\end{array}$ & Campanien & & - \\
\hline-1032 & 1102 & & & & \\
\hline-1146 & 1216 & Kalksten m. grå mergel og lagdelt mergelsten & Santonien & Evre & E. Stenestad, s. 86 \\
\hline-1158 & 1228 & do. & & kridt & \\
\hline-1187 & 1257 & $\begin{array}{l}\text { Kalksten, lys, hård, m. lag af sortgrå } \\
\text { mergelsten }\end{array}$ & Coniacien & & \\
\hline-1221 & 1291 & $\begin{array}{l}\text { Kalksten, gulliggrå, hård; nederst: } \\
\text { Lersten, sort til gråsort }\end{array}$ & Turonien & & \\
\hline-1246 & 1316 & $\begin{array}{l}\text { Mergelsten, grå, m. glaukonit og glimmer. } \\
\text { Lag af grå kalksten }\end{array}$ & ?Cenomanien & & \\
\hline
\end{tabular}




\begin{tabular}{|c|c|c|c|c|c|}
\hline \multirow{2}{*}{$\begin{array}{c}\text { Kote } \\
\text { (korrig.) }\end{array}$} & \multirow{2}{*}{$\begin{array}{c}\text { Dybde i } \\
\text { m under } \\
\text { KB }\end{array}$} & \multirow{2}{*}{ Lithologi } & \multicolumn{2}{|c|}{ Chronostratigrafi } & \multirow{2}{*}{$\begin{array}{l}\text { Henvisning til speciel omtale } \\
\text { (forfatter, sidetal) }\end{array}$} \\
\hline & & & Etage & System & \\
\hline-1259 & 1329 & Lersten, brunlig, delvis rødbrun & Albien & \multirow{5}{*}{$\begin{array}{l}\text { Nedre } \\
\text { kridt }\end{array}$} & \multirow{5}{*}{$\begin{array}{l}\text { A. Buch, s. } 100 \text { og } \\
\text { O. Bruun Christensen s. } 113\end{array}$} \\
\hline-1267 & 1337 & Lersten, gråbrun & Aptien & & \\
\hline-1272 & 1342 & \multirow{3}{*}{$\begin{array}{l}\text { Lersten, overvejende grå-gråsort } \\
\text { do. } \\
\text { Lersten, grå, m. brune lerjernstenskon- } \\
\quad \text { konkretioner }\end{array}$} & Barrémien & & \\
\hline-1278 & 1348 & & Hauterivien & & \\
\hline-1290 & 1360 & & Valanginien & & \\
\hline-1324 & 1394 & & & \multirow{8}{*}{ Jura } & \multirow{4}{*}{ O. Bruun Christensen, s. 113} \\
\hline-1338 & 1408 & $\begin{array}{l}\text { Lersten, mørk gråbrun, m. gråt } \\
\text { glaukonitholdigt finsand }\end{array}$ & & & \\
\hline-1398 & 1468 & Finsandsten, grå, glaukonitholdig & ?Portlandien & & \\
\hline-1423 & 1493 & Lersten, gråsort & Kimmeridgien & & \\
\hline-1439 & 1509 & Lersten, mørkegrå, m. finsandsten & Domérien & & \multirow{4}{*}{$\begin{array}{l}\text { O. Michelsen, s. } 124 \text { og } \\
\text { I. Bang, s. } 119\end{array}$} \\
\hline-1478 & 1548 & do. & Pliensbachien & & \\
\hline-1518 & 1588 & do. & Sinemurien & & \\
\hline-1664 & 1734 & do. & $\begin{array}{l}\text { Sinemurien og } \\
\text { Hettangien }\end{array}$ & & \\
\hline-1777 & 1847 & $\begin{array}{l}\text { Lersten, brunlig og grøngrå, vekslenđe m. } \\
\text { finsandsten }\end{array}$ & \multirow{4}{*}{ Rhæt } & \multirow{10}{*}{ Trias } & \\
\hline-1786 & 1856 & $\begin{array}{l}\text { Lersten, grønlig og brunlig, m. lag af lys } \\
\text { finsandsten }\end{array}$ & & & O. Bruun Christensen, s. 132 \\
\hline-1834 & 1904 & Finsandsten, delvis finkornet, hvidlig & & & \\
\hline-1883 & 1953 & Kalksten, grå, oolitisk & & & \\
\hline-1929 & 1999 & $\begin{array}{l}\text { Lersten, brunlig, vekslende m. grå kalksten } \\
\text { og finsandsten. Anhydrit. }\end{array}$ & & & \multirow{6}{*}{ A. Dinesen, S. 136} \\
\hline-2004 & 2074 & Stensalt $\mathrm{m}$. brun lersten og finsandsten & & & \\
\hline-2150 & 2220 & $\begin{array}{l}\text { Lersten, brun og grå, m. finsandsten og } \\
\text { kalksten }\end{array}$ & & & \\
\hline-2273 & 2343 & Siltsten, gråbrun, vekslende m. lersten & & & \\
\hline-2359 & 2429 & Stensalt $\mathrm{m}$. lersten og siltsten & & & \\
\hline-2548 & 2618 & Lersten, grønlig, vekslende m. siltsten & & & \\
\hline
\end{tabular}




\begin{tabular}{|c|c|c|c|c|c|}
\hline \multirow{2}{*}{$\begin{array}{l}\text { Kote } \\
\text { (korrig.) }\end{array}$} & \multirow{2}{*}{$\begin{array}{c}\text { Dybde i } \\
\text { m under } \\
\text { KB }\end{array}$} & \multirow{2}{*}{ Lithologi } & \multicolumn{2}{|c|}{ Chronostratigrafi } & \multirow{2}{*}{$\begin{array}{l}\text { Henvisning til speciel omtale } \\
\quad \text { (forfatter, sidetal) }\end{array}$} \\
\hline & & & Etage & System & \\
\hline-2727 & 2798 & $\begin{array}{l}\text { Finsandsten, overvejende grå, vekslende } \mathrm{m} \text {. } \\
\text { lersten }\end{array}$ & & \multirow{4}{*}{ Trias } & \multirow{4}{*}{ A. Dinesen, s. 136} \\
\hline-2967 & 3038 & $\begin{array}{l}\text { Lersten, grågrøn og kalksten, grå; nedefter } \\
\text { siltsten og lersten }\end{array}$ & & & \\
\hline-3165 & 3238 & $\begin{array}{l}\text { Lersten, kalksten, siltsten og finsandsten } \\
\text { vekslende }\end{array}$ & & & \\
\hline-3238 & 3313 & $\begin{array}{l}\text { Lersten, gråbrun, vekslende m. siltsten og } \\
\text { finsandsten }\end{array}$ & & & \\
\hline-3345 & 3423 & Stensalt & \multirow{4}{*}{ Zechstein } & \multirow{4}{*}{ Perm } & \multirow{4}{*}{ F. Lyngsie Jacobsen, s. 162} \\
\hline-3406 & 3485 & Anhydrit & & & \\
\hline-3421 & 3501 & Dolomit & & & \\
\hline-3444 & 3524 & Anhydrit - dolomit & & & \\
\hline-3455 & 3535 & Lersten, grâ, delvis i forstyrret lejring & \multirow{8}{*}{$\begin{array}{l}\text { Øve } \\
\text { ludlowien }\end{array}$} & \multirow{10}{*}{ Silur } & \multirow{10}{*}{$\begin{array}{l}\text { O. Bruun Christensen, s. } 150 \\
\text { og } \\
\text { F. Lyngsie Jacobsen, s. } 162\end{array}$} \\
\hline-3457 & 3537 & $\begin{array}{l}\text { Lersten, grå og rød, skifret, m. lag af } \\
\text { finsandsten og dolomit }\end{array}$ & & & \\
\hline-3460 & 3540 & $\begin{array}{l}\text { Finsandsten, dolomitisk, rødbrun, delvis } \\
\text { glimmerholdig, m. lag af lersten, dolomit } \\
\text { og kalksten }\end{array}$ & & & \\
\hline-3499 & 3580 & Basalt, mørk rødbrun, extrusiv & & & \\
\hline-3532 & 3613 & $\begin{array}{l}\text { Lersten, rødbrun, vekslende m. rødbrun } \\
\text { finsandsten }\end{array}$ & & & \\
\hline-3570 & 3652 & $\begin{array}{l}\text { Basalt, rødbrun, extrusiv; m. spredte lag } \\
\text { af lersten }\end{array}$ & & & \\
\hline-3606 & 3688 & Sandsten og finsandsten, rødbrun & & & \\
\hline-3618 & 3700 & Basalt, lersten, sandsten og/el. tuf, vekslende & & & \\
\hline-3641 & 3724 & $\begin{array}{l}\text { Lersten, skifret, brunligrød, m. forekomster } \\
\text { af finsandsten }\end{array}$ & Nedre & & \\
\hline-3679 & 3762 & Slutdybde & ludlowien & & \\
\hline
\end{tabular}


grundlag ARNE BUCH har kunnet give en klar chronostratigrafisk inddeling.

Den temmelig ensformige øvre kretaciske lagserie af lys, oftest hvid, kalksten omfatter aflejringer fra næsten alle kendte etager fra cenoman til maastrichtien. Der er ikke konstateret nogen større afbrydelse af sedimentationen ind i tertiærtiden, hvis aflejringer ved Nøvling omfatter det meste af den kendte jyske lagserie. De mellem-oligocæne lag synes dog at mangle.

Øverst i Nøvling-profilet ligger omtrent $200 \mathrm{~m}$ miocæne aflejringer. Det drejer sig hovedsageligt om limniske lag med horisonter af brunkul. Enkelte marine lag vidner dog om havets indtrængen i perioder.

Allerede i 18 m's dybde, da man begyndte prøvetagningen, var man i miocæne lag. Sandsynligvis er disse overlejret af et tyndt dække af få meter kvartære aflejringer, hvis beskaffenhed der ikke foreligger oplysninger om.

\section{Boringens strukturelle beliggenhed}

Nøvling-boringen ligger strukturelt set på nordflanken af den store regionale Ringkøbing-Fyn Højderyg, hvor prækambriske lag når relativt højt op (se Sorgenfrei \& Buch 1964 og Sorgenfrei 1966, samt fig. 4). Endvidere befinder boringen sig i det sydlige grænseområde af Det Danske Sænkningsområde. Disse forhold belyses i store træk allerede af selve boreprofilet og lagtykkelserne. Gamle palæozoiske (siluriske) lag er nået allerede i 3535 m's dybde, hvilket sammen med det reducerede øvre perms (zechsteins) mægtighed på kun $112 \mathrm{~m}$ understreger den relativt høje strukturelle beliggenhed. Samtidig peger den $2783 \mathrm{~m}$ tykke mesozoiske serie sammen med det faktum, at de fleste underafdelinger af nedre kridt og jura er tilstede, ofte i marin udformning, på bassinmæssige forhold. Det må nemlig erindres, at boringerne oppe på selve Ringkøbing-Fyn Højderyggen alle har vist et meget reduceret nedre kridt profil og som regel fuldstændig mangel på juraaflejringer (SORGENFREI \& BuCH 1964).

De mere detaljerede strukturelle forhold i Midtjylland kan kun illustreres gennem en bearbejdelse af de reflektionsseismiske undersøgelser, som oliefirmaerne Gulf, Esso og Shell har ladet foretage gennem årene fra 1951 til 1967. De mange seismogrammer, kort og andre data er blevet gennemgået og bearbejdet af J. C. BAARTMAN, der har redegjort for resultaterne i sin artikel p. 34. Her skal især henvises til 3 kort, som findes i BAARTMAN's artikel. Det må i denne forbindelse understreges, at kurverne på fig. 7 og 8 forestiller reflektionstiderne og ikke dybderne til de pågældende horisonter. En omregning til dybder ville have været uoverkommeligt inden for den korte frist til arbejdets aflevering. Strukturbilledet er dog ikke anfægtet af dette forhold.

Det fremgår tydeligt af disse kort, at Nøvling-boringen ligger indenfor et bælte med talrige forkastninger parallelle med bassinranden. Disse forkastninger opdeler bæltet i en række blokke, der ligger noget højdeforskudt i forhold til hinanden. Boringen ligger på en af disse blokke. Som det fremgår af kortene ligger den imidlertid hverken på toppen af en detailstruktur på »nedre kridt-fladen« eller på en top af »mellem-keuper fladen«. Der synes slet ikke at 


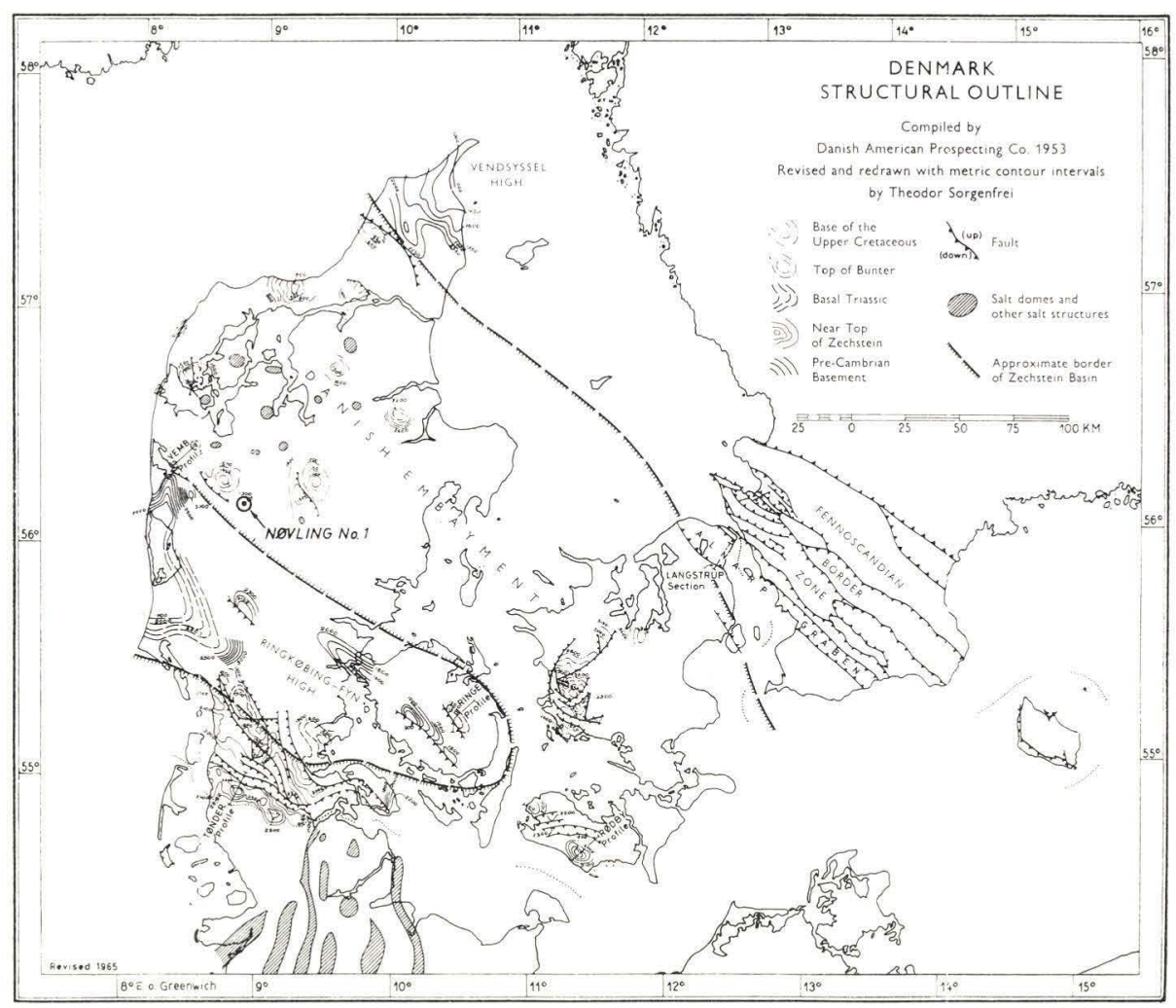

Fig. 4. Nøvling boringens placering i forhold til Det Danske Sænkningsområde (Danish Embayment) og Ringkøbing-Fyn Højdestrukturen. Strukturkortet er fra SoRGENFREI 1966, fig. 6 .

Situation of the Novling boring in relation to the Danish Embayment and the Ringkobing-Fyn High.

være fremtrædende påviselige lokale strukturer i Nøvling-boringens allernærmeste omegn. Begrundelsen for boringens placering må formodentlig søges i de regionalt strukturelle forhold på flanken af Ringkøbing-Fyn Højderyggen, hvor der er relativ kort distance til de palæozoiske lag.

I forbindelse med de mere lokale strukturelle forhold kan nævnes, at Nøvling-boringen ligger kun 3-4 km sydvest for en salthorst (se bl.a. fig. 8 i BAARTMAN's artikel og fig. 5), som almindeligvis kaldes Herning saltdomen. Der kan dog ikke i boringens zechstein serie påvises nogen indflydelse fra saltbevægelserne i salthorsten.

Nøvling-boringens placering i forhold til det nordvestjyske salthorstområde fremgår af kortudsnittet fig. 5, hvor såvel salthorste som andre gravimetriske anomalier er afmærkede. Der er tidligere (i 1947) udført en dybdeboring på den store, flade, antiklinalagtige struktur, $» \mathrm{~W} \ll$, Vinding. Denne boring, Vinding nr. 1, ligger kun $15 \mathrm{~km}$ nordvest for Nøvling-boringen og nåede en slut- 


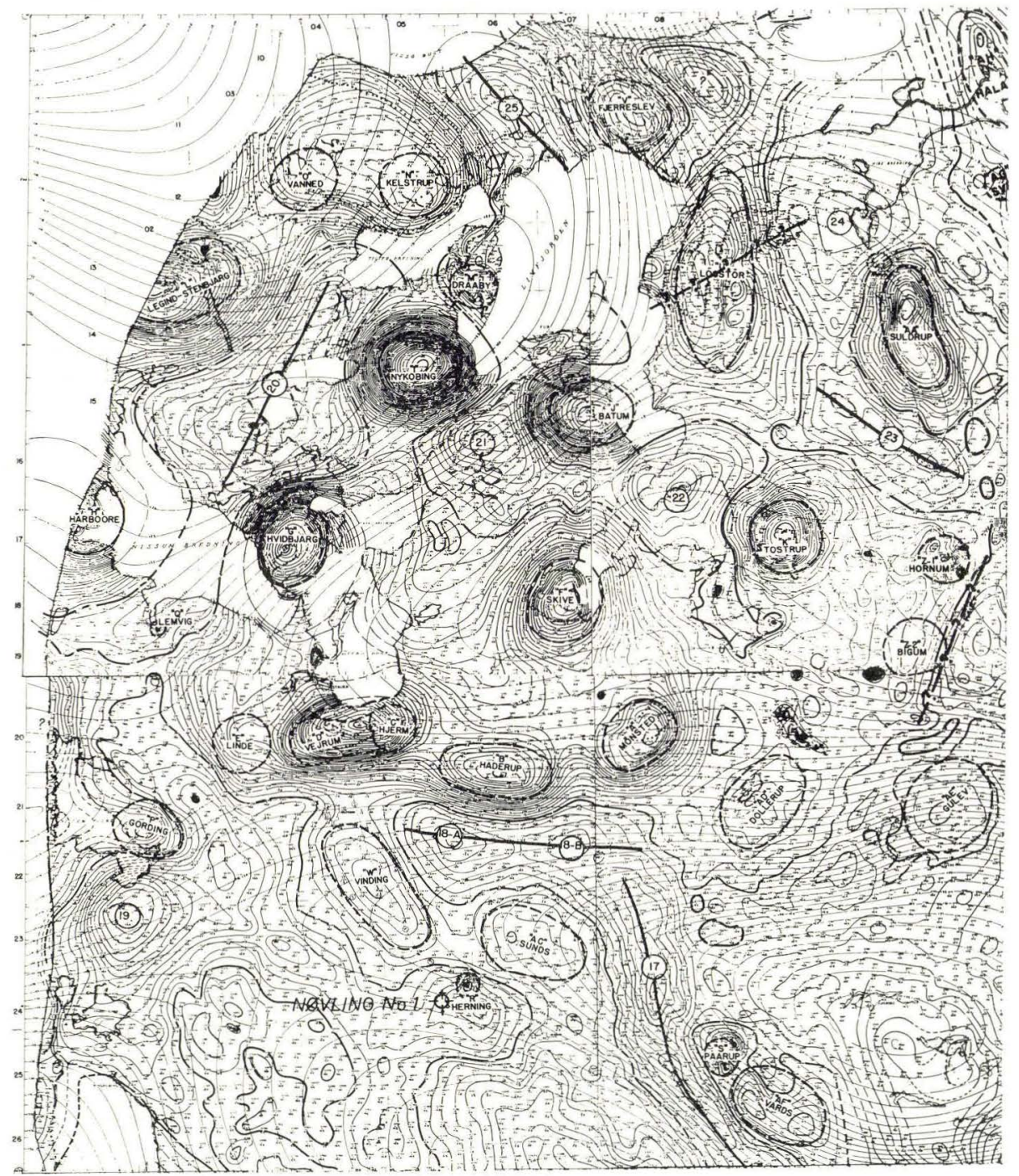

Fig. 5. Nøvling boringens beliggenhed i forhold til tyngdeanomalierne i det nordvestlige Jylland. Kortgrundlaget er et udsnit af en upubliceret foreløbig udgave af et residualtyngdekort over Jylland, udarbejdet i 1947 af Gulf Research \& Development Co., Pittsburgh, USA. Kurveinterval $=0,5$ mgal. Massefylde $=2,0$. Minima er afmærkede med stort bogstav og stednavn, medens maxima er betegnede med tal i cirkel. De runde minima tolkes som salthorste og de aflange minima som saltantiklinaler.

Situation of the Novling boring in relation to the gravity anomalies in the northwestern part of Jutland. The base map is a section of an unpublished preliminary edition of an assembly map of residual gravity made by Gulf Research \& Development Co., Pittsburgh, 1947. Contour interval $=0.5 \mathrm{mgal}$. Density $=2.0$. 
dybde på 2429 m i aflejringer fra trias (se SORGENFREI \& BUCH 1964, pp. 89-90). Som det fremgår af fig. 7-9 hos BAARTMAN ligger Vinding boringen også tæt op ad forkastningszonen på flanken af Ringkøbing-Fyn Højderyggen. I modsætning til Nøvling-boringen er den placeret på nordsiden af zonen og på toppen af en struktur, der gør sig gældende på såvel »nedre kridt fladen« som »mellem keuper fladen « og måske også i zechsteinlagene.

Vinding-boringen var den første egentlige dybdeboring, som DANISH AMERican Prospecting Co. udførte her i landet, og man ønskede dengang at undersøge først og fremmest zechstein evaporiterne tillige med beskaffenheden af de mesozoiske aflejringer. Der blev ikke udført reflektionsseismiske undersøgelser forud for planlægningen af boringen, hvis placering hovedsageligt er sket på grundlag af lokaliseringen af et tyngdeminimum. Både de gravimetriske interpretationer og fortolkningen af en mindre refraktionsseismisk undersøgelse peger på, at der forelå en dybtliggende saltstruktur: en salthorst eller en saltantiklinal, i alle tilfælde en struktur forårsaget af saltkoncentration på grund af halokinese.

Nøvling-boringen og Vinding-boringen ligger således på to væsensforskellige lokalstrukturer, men på grund af den ret korte afstand mellem dem er det naturligt at sammenligne de gennemborede post-triassiske lag i de to boringer. Dette er da også sket flere gange i de følgende artikler, selvom prøverne fra Vinding-boringen stort set kun er mindre grundigt undersøgt.

\title{
Gas- og olieforekomster i boringen
}

Hensigten med boringen har hovedsageligt været at undersøge lagene fra øvre perm (zechstein), eventuelt forekommende sandsten fra nedre perm (rotliegendes) samt de mesozoiske aflejringer for forekomster af kulbrinter.

Som anført på det af ARne Dinesen udførte diagram fig. 2, p. 12, blev der foretaget 2 undersøgelser, hvor man sugede vædske ud af formationen (»drill stem tests «). Det skete i intervallerne $11486^{\prime}-11565^{\prime}$ og $11582^{\prime}-12342^{\prime}$. Begge undersøgelser viste, at der ikke fandtes kulbrinter. I sidstnævnte interval påvistes nitrogen gas (kvælstof) i ganske små mængder.

Boringen må således $\mathrm{i}$ henseender til sit egentlige formål betegnes som negativ.

\author{
ENGLISH TRANSLATION \\ (by SVEnd E. HENRIKSEN) \\ NØVLING NO. 1 \\ SUMMARY OF THE HISTORY OF THE BORING AND \\ THE GEOLOGICAL RESULTS
}

The time of drilling

The deep test Nøvling No. 1 was started the 13 th September, 1966 and was finished the 15th November of the same year. Various petrophysical tests (Schlumberger loggings) 
were made, after which the borehole was closed the 25th November, 1966 and the equipment was moved to the next drilling site on the island of Mors.

The boring has file number 84.1777 in the Well Record Department of the Geological Survey of Denmark.

\section{The location of the boring}

The boring site was situated in a field a short distance southwest of the farm "Egbæk"; it was about $1.7 \mathrm{~km}$ southwest of Nøvling Church on the Geodetic Institute plane table sheet M 2405 or $4 \mathrm{~cm}$ map 1114 I NØ (see the map section fig. 1, p. 10). Nøvling Church is about $8 \mathrm{~km}$ northwest of Herning. The geographical coordinates of the boring are $8^{\circ} 48^{\prime}$ $36^{\prime \prime} \mathrm{E}$ and $56^{\circ} 10^{\prime} 09^{\prime \prime} \mathrm{N}$ in the Greenwich system.

\section{The administration of the boring}

The boring was made by DANSK UNDERGRUNDS CONSORTIUM (abbreviated DUC), which comprises among others the company A. P. MøLLER, which holds the monopoly of prospecting and production of hydrocarbons. All transfer of material under obligation to be delivered to the State was made through the company of A. P. Møller.

The daily work of the exploration activity was made by the Gulf Oil Company of DenMARK, which had the geologist Mr. RoBERT K. KIRKBRIDE stationed at the boring. He was like at the Rønde boring - also at this boring of great help for the D.G.U. geologist stationed there.

The collecting of the technical data and the taking of the drilling samples were performed by the personnel of the Formation Logging Service Co. (Peters Logging S.A.), with whom the D.G.U. geologist was in daily contact and from whom were received copies of the diagrams outlining the technical data.

At certain occasions petrophysical measurements were made in the borehole by the SCHLUmberger company. These borehole loggings (Schlumberger logs) include a number of measurements of significance for the evaluation of the diameter of the boring at any depth, its inclination and direction, etc., besides the important measurements of the physical properties of the beds encountered and their exact position. Information on the types of measurements, intervals, etc. is shown in ARNE Dinesens diagram of the technical data, fig. 2, p. 12.

The actual drilling work was made by the ReAding \& Bates Offshore Drilling Co. by means of a rig of the type "Oilwell $940 \mathrm{E}$ ".

\section{Drilling method}

The boring was made by rotary drilling, and coring was done in only four intervals, namely $11555^{\prime}-11612^{\prime}$ (core No. 1), 11614'-11676' (core No. 2), 11896'-11932' (core No. 3) and $12311^{\prime}-12342^{\prime}$ ( core No. 4). The samples from the other parts of the boring consist of 780 ditch samples; these form the basic material for the lithologic and biostratigraphical studies.

\section{Boring and casing diameters}

After a so-called conductor pipe was placed at a depth of $15^{\prime}(4.6 \mathrm{~m})$, the boring continued with a drill bit diameter of $26^{\prime \prime}$ down to $518^{\prime}(158 \mathrm{~m})$. Then a $20^{\prime \prime}$ casing was placed at $517^{\prime}$, and drilling continued with a $17 \frac{1}{2}^{\prime \prime}$ bit from $518^{\prime}(158 \mathrm{~m})$ to $3510^{\prime}(1070 \mathrm{~m})$. After a new casing of $13 \frac{3{ }^{\prime \prime}}{8}$ was placed at $3509^{\prime}$, boring continued with a $12 \frac{1}{4}^{\prime \prime}$ bit from $3510^{\prime}$ (1070 $\mathrm{m})$ to $11555^{\prime}(3522 \mathrm{~m})$. From this depth to the final depth $12342^{\prime}(3762 \mathrm{~m})$ an $8 \frac{7}{16}^{\prime \prime}$ core 
bit was used alternatingly with an $8 \frac{1}{2}$ " ordinary bit. Immediately after the taking of core No. $1\left(11555^{\prime}-11612^{\prime}\right)$ a $95^{\prime \prime}$ casing was placed at $11582^{\prime}(3530 \mathrm{~m})$. This casing is not shown in the schematic view of the boring in the diagram of the technical data fig. 2, p. 12.

Concerning the diameters of the drill bits and casings as well as all other technical data, the reader is referred to this diagram, which has been made by ARNE Dinesen.

\section{Sample intervals}

In the beginning of the boring, ditch samples were taken every $30^{\prime}$; later they were taken every $10^{\prime}$ except for certain intervals, in which samples were taken every $15^{\prime}$ or $20^{\prime}$. For details, see fig. 2.

\section{Depth figures}

The designation of the depth is a difficult matter. All depths measured by the drilling contractor were given in terms of English feet below the Kelly Bushing (abbreviated KB), while the depths given in the Schlumberger logs were given in terms of metres below KB. Furthermore, it is often necessary to correct the depth figures for the delay of the ditch samples and the deviation of the borehole, as described below.

Since the problems concerning the depth figures are exactly the same as for the Rønde boring, the discussion of them, given on p. 13 of the report on that boring, is here repeated in full.

In the biostratigraphic and lithologic intervals described in this work, the depths are all given in English feet and correspond to the values given by the drilling contractor, but in certain cases in which it has been necessary to support the lithologic description of the beds by the indications of the Schlumberger logs the derterminations of depth are given primarily in terms of metres below KB. It has then been most expedient to convert the depth designations to English feet. Such converted depths are in the text given in italics.

The original designations of depth, given in English feet below KB, thus make up the fundamental set of depth indications, given to all samples. Thus, if one wants to refer back to samples in the storage rooms of the DGU or to the collections of microfossil slides, one will find the desired sample or slide under its original depth indication in terms of English feet below KB.

This depth is, however, not exact, as there exist two circumstances which the sampler and the label writer have not been able to take into consideration, and which will be briefly described here. They are: 1) the delay of the ditch samples and 2) the deviation of the borehole.

1. The delay (lag) of the ditch samples. Before the cuttings reach the surface they have had to travel a long distance, the longer the deeper the boring is. By this travel the cuttings are delayed some minutes, so that the depth at which they were drilled is passed and is no longer the actual depth of drilling at the moment when they reach the surface. The sampler, however, can only write on the sample bag the depth at which the drill crown is then drilling. This delay in time (the so-called lag time) is, however, measured at certain intervals, so that it is possible to calculate a more correct depth (relative to the KB). These corrected depths are, however, not yet the exact depths. Arne Dinesen has made a diagram (fig. 3), by means of which it is possible to estimate the magnitude of the delay, both in terms of lag time and lag distance.

2. The deviation of the borehole. The direction of the borehole in a deep boring is hardly ever exactly vertical. It may in some cases show quite large deviations, which of course affect the determination of the exact position of the beds in the three dimensions and relative to the sea level. The methods with which these errors of position are corrected are described in the article by Svend E. Henriksen, p. 54. 
The well-site geologist from the D.G.U. and his duties

During the entire period of drilling, a geologist from the D.G.U. was stationed at the wellsite, where a field laboratory was established by the D.G.U., like at the Rønde boring. The coordinator of this field work was also at this boring ARNE DINESEN

The following D.G.U. geologists were stationed at Nøvling No. 1:

\begin{tabular}{l|l|l} 
Period of duty & Name of geologist & $\begin{array}{c}\text { Interval } \\
\text { lithologically } \\
\text { described }\end{array}$ \\
\hline $\begin{array}{l}\text { 13. Sept. }-14 \text {. Oct. } \\
\text { 14. Oct. }- \text { 18. Nov. }\end{array}$ & $\begin{array}{l}\text { Olaf Michelsen } \\
\text { Torben Juul Hansen } \\
\text { Olaf Michelsen }\end{array}$ & $\begin{array}{r}0^{\prime}-9680^{\prime} \\
9680^{\prime}-12342^{\prime}\end{array}$ \\
\hline
\end{tabular}

The work of the well-site geologist comprised two main tasks, namely 1) to follow closely the technical part of the drilling activities, especially those having to do with the borehole itself, and 2) to make a careful study of the drilling samples and to pack and forward them to the D.G.U. Besides these two tasks, the geologist as required to keep constantly in touch with the DUC's geologists and contractors at the well-site and seek information about the forthcoming operations and obtain explanations of the technical questions which often came up during the progress of the drilling operations.

The D.G.U. well-site geologist was to send in the following material to the D.G.U.:

1. Description of all samples taken, namely ditch and bit samples, and core samples.

2. A geologic evaluation of the series penetrated as it appeared at the well site at the time of sampling (the so-called geologist's log).

3. All technical data, including measurements of the drilling rate, depth of change of drill crown, type of bit used, measurements of the deviation of the borehole relative to the vertical, setting of casing, diameter of casing and borehole, etc.

4. All drilling samples and other material concerning the boring received.

In addition, frequent telephone contacts were made with the Pre-Quaternary Department in order to keep the D.G.U. in daily contact with events and progress of the boring.

The work done in the laboratories of the D.G.U.

As was the case for the Rønde boring, the samples taken were examined for their microfauna concurrently with the work of the well-site geologist. These examinations were made in the Pre-Quaternary Department of the D.G.U. and formed the basis for a preliminary biostratigraphic and chronostratigraphic division of the series of beds penetrated. The major part of these preliminary examinations were made by ARNE BUCH and ERIK STENESTAD.

Several of the geologists of the Pre-Quaternary Department have later given the samples from their respective units of geologic time a closer study, their special knowledge of particular geologic periods making it possible for them to reach a quick overview. This work was distributed as shown by the individual contributions to this book.

During the boring, biostratigraphical summaries based on studies of the foraminifera were made by ARNE Buch.

Preliminary studies of sediments and fossil contents in the cores No. 1-4 were made by Ole BruUn Christensen immediately after the arrival of the cores at Copenhagen. His reports on these studies have later been published in slightly changed form (see CHRISTENSEN 1971). 


\section{Outline of the geology of the Novling profile}

The most important geological result of this boring was the demonstration of Upper Silurian deposits directly under beds of Zechstein age. Already during the boring, OLE BRUUN Christensen showed that the beds below the Zechstein evaporites contained fossils of Upper Silurian age. In the deepest-lying shaly claystone he succeeded in finding Colonograptus colonus, and in the overlying siltstone were found remains of brachiopods, ostracods, pelecypods, gastropods, orthoceras, tentaculites, conodonts, conularids, crinoids, corals and trilobites.

The reddish deposits resemble at first sight the beds found in the Övad-Ramsåsa Series of Scania. During a visit to the localities in Scania together with BRUUN CHRISTENSEN and T. JUUL HANSEN in March 1967, I had the opportunity of having this resemblance confirmed. Here we found a great resemblance between the sediments at Nøvling and the beds at the type locality at Ramsåsa. Even if this locality is a quarry which was given up a long time ago and now is partly filled with refuse, and whose sides also are to some extent covered with a vegetation of trees and bushes, it was yet possible to find some fairly good exposures, and by digging to find fossiliferous Silurian beds. The similarity to the Nøvling beds was striking.

A fairly surprising find was the basalt layers in the Silurian series at Nøvling. Volcanic activity in the Upper Silurian has not hitherto been demonstrated with certainty for Northern Europe, but in the final phase of the Caledonian Orogeny it would not be unlikely to have volcanic activity, and Nøvling is situated not unreasonably far from the Caledonian region.

The volcanites of Nøvling have been age-determined by means of the potassium/argon method by OLE LARSEN (1972), who found them to be 276 million years old $( \pm 12$ million years), which corresponds to a Permian age. This fact he explains by supposing that the volcanites may have lost radiogene argon some time in the Permian. The Silurian age of the sediments enclosing the volcanites cannot be doubted.

Between the Silurian and the Permian beds of Nøvling there is a considerable unconformity and hiatus. There is no evidence of beds of the Devonian, Carboniferous and Lower Permian. Presumably the area has been situated above sea level during the larger part of this interval. Without doubt a contributing fact has been the situation of this place on the north flank of the large Ringkøbing-Fyn High.

This situation also explains why the Zechstein series in the Nøvling boring is reduced to include only an about $100 \mathrm{~m}$ thick series of evaporites. It is hardly possible to determine to which of the known cycles this series belongs. For the time being, this is the only known Zechstein profile on the north flank of the Ringkøbing-Fyn High. A correspondingly reduced series is known from the Arnum boring on the south flank of the structure.

The transition to the overlying Triassic beds seems to be very even and apparently without any long-continued interruption of the sedimentation. The Triassic series of Nøvling shows the same monotonous nature which characterizes the Triassic profiles of northern Jutland, in which it is not possible to demonstrate the "Germanic" division into the three subdivisions Buntsandstein, Muschelkalk and Keuper, known from the south-Danish basin, unless it may be permitted to correlate the rock salt layer found about in the middle of the Triassic series with certain of the Muschelkalk evaporites in southern Denmark and northern Germany.

The Rhaetic is here included in the Triassic period. The interval is at Nøvling represented by both marine and limnic deposits, and the age is verified by means of ostracods (O. BRUUN Christensen).

The overlying Lower Jurassic beds are well subdivided, thanks to well-preserved ostracod faunas (Olaf Michelsen). The foraminiferal content, on the other hand, was not found suitable for a biostratigraphic subdivision of the Lower Jurassic series in Nøvling. There 
Summary of the drilled geological sequence

\begin{tabular}{|c|c|c|c|c|c|}
\hline \multirow{2}{*}{$\begin{array}{c}\text { Level } \\
\text { (corrected) }\end{array}$} & \multirow{2}{*}{$\begin{array}{l}\text { Depth } \\
\text { (in m } \\
\text { below } \\
\text { KB) }\end{array}$} & \multirow{2}{*}{ Lithology } & \multicolumn{2}{|c|}{ Chronostratigraphy } & \multirow{2}{*}{$\begin{array}{l}\text { Reference to detailed description } \\
\text { (author, page) }\end{array}$} \\
\hline & & & Stage & System & \\
\hline+69 & 0 & (Kelly Bushing (abbreviated KB)) & & & \\
\hline+62 & 7 & (No informations) & & $\begin{array}{l}\text { Quaternary } \\
\text { and Tertiary }\end{array}$ & \\
\hline+51 & 18 & $\begin{array}{l}\text { Sand alternating with micaceous clay. } \\
\text { Beds of brown coal }\end{array}$ & Miocene & & F. Nyhuus Kristoffersen, p. 67 \\
\hline-132 & 201 & Clay, dark brownish, micaceous & Oligocene & & \\
\hline-243 & 312 & $\begin{array}{l}\text { Clay, sticky, calcareous, light grey } \\
\text { (Søvind Marl) }\end{array}$ & & & \\
\hline-248 & 317 & $\begin{array}{l}\text { Transition between light grey clay and } \\
\text { sticky, greenish clay (Lillebælt Clay) }\end{array}$ & & & \\
\hline-283 & 352 & Clay, sticky, greenish (Lillebælt Clay) & Eocene & & A Dinesen n 80 \\
\hline-296 & 365 & $\begin{array}{l}\text { Transition between sticky, greenish clay and } \\
\text { sticky reddish brown clay (Røsnæs Clay) }\end{array}$ & & Tertiary & A. Dinesen, p. 80 \\
\hline-339 & 408 & $\begin{array}{l}\text { Clay, sticky, reddish brown (Røsnæs Clay) } \\
\text { and dark clay w/ beds of volcanic tuf }\end{array}$ & & & \\
\hline-358 & 427 & $\begin{array}{l}\text { Clay, sticky, grey, calcareous } \\
\text { (Kerteminde Clay) }\end{array}$ & Selandian & & \\
\hline-456 & 525 & Lime siltstone, clayey in upper part & seranuian & & I. Bang, p. 84 \\
\hline-481 & 550 & Limestone, white & Danian & & \\
\hline-571 & 640 & Chalk, white, w/ beds of chert & Maastrichtian & & \\
\hline-814 & 884 & $\begin{array}{l}\text { Limestone, white or greyish white, w/ beds } \\
\text { of light grey marl }\end{array}$ & & & \\
\hline-991 & 1061 & $\begin{array}{l}\text { Limestone, white or greyish white, w/ } \\
\text { greenish grey, micaceous marl }\end{array}$ & Campanian & Upper & \\
\hline-1032 & 1102 & as above & & Cretaceous & E. Stenestad, p. 95 \\
\hline-1146 & 1216 & $\begin{array}{l}\text { Limestone w/ grey marl and bedded } \\
\text { marlstone }\end{array}$ & Santonian & Cretaceous & \\
\hline-1158 & 1228 & as above & & & \\
\hline-1187 & 1257 & $\begin{array}{l}\text { Limestone, light, hard, w/ beds of dark } \\
\text { grey marlstone }\end{array}$ & Coniacian & & \\
\hline-1221 & 1291 & $\begin{array}{l}\text { Limestone, yellowish grey; hard; in lower } \\
\text { part: Claystone, dark grey }\end{array}$ & Turonian & & \\
\hline-1246 & 1316 & $\begin{array}{l}\text { Marlstone, grey w/ glauconite and mica. } \\
\text { Beds of grey limestone }\end{array}$ & ?Cenomanian & & \\
\hline
\end{tabular}




\begin{tabular}{|c|c|c|c|c|c|}
\hline \multirow{2}{*}{$\begin{array}{c}\text { Level } \\
\text { (corrected) }\end{array}$} & \multirow{2}{*}{$\begin{array}{l}\text { Depth } \\
\text { (in m } \\
\text { below } \\
\text { KB) }\end{array}$} & \multirow{2}{*}{ Lithology } & \multicolumn{2}{|c|}{ Chronostratigraphy } & \multirow{2}{*}{$\begin{array}{l}\text { Reference to detailed description } \\
\text { (author, page) }\end{array}$} \\
\hline & & & Stage & System & \\
\hline-1259 & 1329 & \multirow{5}{*}{$\begin{array}{l}\text { Claystone, brownish, in part reddish brown } \\
\text { Claystone, greyish brown } \\
\text { Claystone, mostly grey or greyish black } \\
\text { as above } \\
\text { Claystone, grey, w/ brown clay ironstone } \\
\text { concretions }\end{array}$} & Albian & \multirow{5}{*}{$\begin{array}{l}\text { Lower } \\
\text { Cretaceous }\end{array}$} & \multirow{5}{*}{$\begin{array}{l}\text { A. Buch, p. } 110 \text { and } \\
\text { O. Bruun Christensen, p. } 118\end{array}$} \\
\hline-1267 & 1337 & & Aptian & & \\
\hline-1272 & 1342 & & Barremian & & \\
\hline-1278 & 1348 & & Hauterivian & & \\
\hline-1290 & 1360 & & Valanginian & & \\
\hline-1324 & 1394 & as above & & \multirow{8}{*}{ Jurassic } & \multirow{4}{*}{ O. Bruun Christensen, p. 118} \\
\hline-1338 & 1408 & $\begin{array}{l}\text { Claystone, dark greyish brown, w/ grey } \\
\text { glauconitic finesand }\end{array}$ & & & \\
\hline-1398 & 1468 & Siltstone, grey, glauconitic & ?Portlandian & & \\
\hline-1423 & 1493 & Claystone, greyish black & Kimmeridgian & & \\
\hline-1439 & 1509 & Claystone, dark grey, w/ siltstone & Domerian & & \multirow{4}{*}{$\begin{array}{l}\text { O. Michelsen, p. } 130 \text { and } \\
\text { I. Bang, p. } 122\end{array}$} \\
\hline-1478 & 1548 & as above & Pliensbachian & & \\
\hline-1518 & 1588 & as above & Sinemurian & & \\
\hline-1664 & 1734 & as above & $\begin{array}{l}\text { Sinemurian and } \\
\text { Hettangian }\end{array}$ & & \\
\hline-1777 & 1847 & $\begin{array}{l}\text { Claystone, brownish and greenish grey, } \\
\text { alternating w/ siltstone }\end{array}$ & & \multirow{11}{*}{ Triassic } & \\
\hline-1786 & 1856 & $\begin{array}{l}\text { Claystone, greenish and brownish, w/ beds } \\
\text { of light siltstone }\end{array}$ & Rhaetic & & O. Bruun Christensen, p. 135 \\
\hline-1834 & 1904 & Siltstone, in part finegrained, whitish & & & \\
\hline-1883 & 1953 & Limestone, grey, oolitic & & & \\
\hline-1929 & 1999 & $\begin{array}{l}\text { Claystone, brownish, alternating w/ grey } \\
\text { limestone and siltstone. Anhydrite }\end{array}$ & & & \multirow{7}{*}{ A. Dinesen, p. 143} \\
\hline-2004 & 2074 & Rock salt w/ brown claystone and siltstone & & & \\
\hline-2150 & 2220 & $\begin{array}{l}\text { Claystone, brown and grey, w/ siltstone and } \\
\text { limestone }\end{array}$ & & & \\
\hline-2273 & 2343 & $\begin{array}{l}\text { Siltstone, greyish brown, alternating } \\
\text { w/ claystone }\end{array}$ & & & \\
\hline-2359 & 2429 & Rock salt w/ claystone and siltstone & & & \\
\hline-2548 & 2618 & Claystone, greenish, alternating w/ siltstone & & & \\
\hline-2727 & 2798 & $\begin{array}{l}\text { Siltstone, mainly grey, alternating } \\
\text { w/ claystone }\end{array}$ & & & \\
\hline
\end{tabular}




\begin{tabular}{|c|c|c|c|c|c|}
\hline \multirow{2}{*}{$\begin{array}{c}\text { Level } \\
\text { (corrected) }\end{array}$} & \multirow{2}{*}{$\begin{array}{l}\text { Depth } \\
\text { (in m } \\
\text { below } \\
\text { KB) }\end{array}$} & \multirow{2}{*}{ Lithology } & \multicolumn{2}{|c|}{ Chronostratigraphy } & \multirow{2}{*}{$\begin{array}{l}\text { Reference to detailed description } \\
\text { (author, page) }\end{array}$} \\
\hline & & & Stage & System & \\
\hline-2967 & 3038 & $\begin{array}{l}\text { Claystone, greyish green and grey limestone; } \\
\text { downwards siltstone and claystone }\end{array}$ & & & \\
\hline-3165 & 3238 & $\begin{array}{l}\text { Claystone, limestone, and siltstone } \\
\text { alternating }\end{array}$ & & & \\
\hline-3238 & 3313 & $\begin{array}{l}\text { Claystone, greyish brown, alternating } \\
\text { w/ siltstone }\end{array}$ & & Triassic & A. Dinesen, p. 143 \\
\hline-3345 & 3423 & Rock salt & \multirow{4}{*}{ Zechstein } & \multirow{4}{*}{ Permian } & \multirow{4}{*}{ F. Lyngsie Jacobsen, p. 149} \\
\hline-3406 & 3485 & Anhydrite & & & \\
\hline-3421 & 3501 & Dolomite & & & \\
\hline-3444 & 3524 & Anhydrite - dolomite & & & \\
\hline-3455 & 3535 & Claystone, grey, partly disturbed & \multirow{8}{*}{$\begin{array}{l}\text { Upper } \\
\text { Ludlovian }\end{array}$} & \multirow{10}{*}{ Silurian } & \multirow{10}{*}{$\begin{array}{l}\text { O. Bruun Christensen, p. } 156 \\
\text { and } \\
\text { F. Lyngsie Jacobsen, p. } 163\end{array}$} \\
\hline-3457 & 3537 & $\begin{array}{l}\text { Claystone, grey and red, shaly, w/ beds of } \\
\text { siltstone and dolomite }\end{array}$ & & & \\
\hline-3460 & 3540 & $\begin{array}{l}\text { Siltstone, dolomitic, reddish brown, partly } \\
\text { micaceous, w/ beds of claystone, dolomite } \\
\text { and limestone }\end{array}$ & & & \\
\hline-3499 & 3580 & Basalt, dark reddish brown & & & \\
\hline-3532 & 3613 & $\begin{array}{l}\text { Claystone, reddish brown, alternating } \\
\text { w/ reddish brown siltstone }\end{array}$ & & & \\
\hline-3570 & 3652 & Basalt, reddish brown; w/ beds of claystone & & & \\
\hline-3606 & 3688 & Sandstone and siltstone, reddish brown & & & \\
\hline-3618 & 3700 & $\begin{array}{l}\text { Basalt, claystone, sandstone and/or volcanic } \\
\text { tuf alternating }\end{array}$ & & & \\
\hline-3641 & 3724 & $\begin{array}{l}\text { Claystone, shaly, brownish red, w/ occur- } \\
\text { ences of siltstone }\end{array}$ & \multirow{2}{*}{$\begin{array}{l}\text { Lower } \\
\text { Ludlovian }\end{array}$} & & \\
\hline-3679 & 3762 & Final depth & & & \\
\hline
\end{tabular}


are many foraminifera, and they are also well preserved, but the faunas have been very much mixed in the boring samples, so that INGER BANG, who has studied them, has not had any possibility of determining the exact position of the boundaries of the different stages. In the diagram showing the formations penetrated in the boring (p. 28) the subdivision given is the one resulting from the study of the ostracods.

The Upper Jurassic beds, on the contrary, contain very sparing amounts of both ostracods and foraminifera. Here it is therefore fairly uncertain how the series is to be subdivided into stages. However, it is certain that Kimmeridgian deposits are present. Possibly also beds of the Portlandian are represented.

The transition from Jurassic to Lower Cretaceous is very even, and it is also biostratigraphically difficult to delimit these two periods exactly in the Nøvling boring. The Lower Cretaceous series consists of fairly uniform beds of claystone. They contain, however, a rich foraminiferal fauna, on the basis of which ARNE BUCH has been able to make a clear chronostratigraphical subdivision.

The rather monotonous Upper Cretaceous series, consisting of light-coloured, usually white limestones, comprises deposits from almost all known stages from the Cenomanian to the Maastrichtian. There has not been found any larger interruption of the sedimentation at the transition to the Tertiary, the sediments of which at Nøvling comprises the major part of the series known in Jutland. However, the Middle Oligocene beds seem to be missing.

Uppermost in the Nøvling profile are found almost $200 \mathrm{~m}$ of Miocene deposits. They are mainly limnic beds with horizons of lignite. A few marine beds show, however, that the sea has transgressed at certain times.

At a depth of $18 \mathrm{~m}$, when sampling was begun, the boring was already in Miocene beds. These are probably overlain by a thin cover consisting of a few metres of Quaternary deposits. Concerning the nature of these, no data are available.

\section{The structural placement of the boring}

The Nøvling boring is placed structurally on the north flank of the great, regional Ringkøbing-Fyn High, in which the Pre-Cambrian rocks reach a relatively large elevation (see Sorgenfrei \& BUCh 1964 and Sorgenfrei 1966 and fig. 4). Furthermore the boring is situated in the southern border area of the Danish Embayment. Even the boring profile itself and the thickness of the layers illustrate these facts in the main. Early Paleozoic (Silurian) beds are reached already at a depth of $3535 \mathrm{~m}$, which together with the thickness of only $112 \mathrm{~m}$ of the reduced Upper Permian (Zechstein) emphasizes the relatively high structural position. At the same time the great thickness of the Mesozoic series (2783 m) and the presence, often in the form of marine deposits, of most of the subdivisions of the Jurassic and Lower Cretaceous point to basin-like conditions of deposition. In contrast to this stands the fact that every one of the borings in the Ringkøbing-Fyn High itself have shown a very reduced Lower Cretaceous profile and usually a complete lack of Jurassic deposits (Sorgenfrei \& Buch 1964).

The more detailed structural relations in Central Jutland can only be illustrated through an interpretation of the reflection-seismic data produced by the oil companies Gulf, Esso and Shell during the years 1951-1967. The numerous seismograms, maps and other data have been studied and worked on by J. C. BAARTMAN, who has explained the results of this in his article on p. 34. The reader is especially referred to three maps in BAARTMAN's article. In this connection it must be emphasized that the contour lines in figs. 7 and 8 represent reflection times and not depths to the respective horizons. Recalculation into depths was found to be too time-consuming to be able to become ready for publication of this work. The structural picture is, however, not affected by this.

These maps show clearly that the Nøvling boring is situated within a zone with many 
faults running parallel to the edge of the basin. These faults subdivide the zone into a number of blocks which are vertically displaced relative to one another. The boring is located in one of these blocks. As shown by the maps, it is, however, placed neither at the top of a structural detail of the "Top Lower Cretaceous" surface nor at a top of the "Middle Keuper" surface. There do not seem to be any significant, recognizable local structures in the immediate vicinity of the Nøvling boring. The reason for the placement of the boring at this position must presumably be sought in the regionally structural relations on the flank of the Ringkøbing-Fyn High, where the distance to the Paleozoic beds is relatively short.

In connection with the discussion of the more local structural relations it may be mentioned that the Nøvling boring is situated only $3-4 \mathrm{~km}$ southwest of a salt horst (see among other places fig. 8 in BAARTMAN's article and fig. 5) which is generally called the Herning salt dome. The Zechstein series of the boring does, however, not show any influence from the salt movements in the salt horst.

The location of the Nøvling boring relative to the salt horst region of northwestern Jutland is shown in the map section fig. 5, in which both the salt horsts and the other gravimetric anomalies are shown. Earlier (in 1947) a deep boring (Vinding) was made in the large, flattened, anticlinal-like structure "W". This boring, Vinding No. 1, is situated only $15 \mathrm{~km}$ northwest of the Nøvling boring; it reached a final depth of $2429 \mathrm{~m}$ in deposits of Triassic age (see SORGENFreI \& BuCH 1964, pp. 89-90).

As shown in figs. 7-9 in BAARTMAN's article, also the Vinding boring is located close to the faulting zone on the flank of the Ringkøbing-Fyn High. Contrary to the Nøvling boring, it is placed on the north side of the zone and also at the top of a structure which is marked both in the "Top Lower Cretaceous" surface and the "Middle Keuper" surface and possibly also in the Zechstein beds.

The Vinding boring was the first really deep boring which Danish American Prospecting Co. made in Denmark, and it was at that time desired to investigate first and foremost the Zechstein evaporites and the nature of the Mesozoic deposits. There were made no reflection-seismic investigations before the planning of the boring, the placement of which was made mainly on the basis of the localization of a gravity low. Both the gravimetric interpretations and the interpretation of a smaller refraction-seismic investigation indicated the presence of a deep lying salt structure: a salt horst or a salt anticline, at any rate a structure caused by a concentration of salt due to halokinese.

The Nøvling and the Vinding borings are thus located on two basically different local structures, but because of the relatively short distance between them it seems natural to compare the post-Triassic deposits penetrated in the two borings. Such comparison has been made at several places in the following articles, even if the samples from the Vinding boring have been only cursorily studied.

\section{Gas and oil occurrences in the boring}

The purpose of the boring was to study the deposits from Upper Permian (Zechstein), possibly occurring sandstone from Lower Permian (Rotliegendes) and the Mesozoic deposits for occurrences of hydrocarbons.

As shown in the diagram by ARNE DINESEN, fig. 2, p. 12, two tests were made, in which liquid was pumped out of the formation (drill stem tests). These were made in the intervals $11486^{\prime}-11565^{\prime}$ and $11582^{\prime}-12342^{\prime}$. Both of these tests showed absence of hydrocarbons. In the latter interval nitrogen gas was found in very small quantity.

Thus the boring must be described as negative with respect to its main purpose. 


\section{LITTERATUR}

Christensen, Ole Bruun, 1971: Øvre silur i dybdeboringen Nøvling nr. 1 i Midtjylland. Danm. geol. Unders. Rapp. nr. 7, 24 pp.

LARSEN, Ole, 1971: Kalium/argon datering af prøver fra danske dybdeboringer. - Dansk geol. Foren. Årsskrift for 1971, pp. 91-94.

RASMussen, L. BANke, 1971: Rønde nr. 1. Oversigt over boringens historie og geologiske resultater. In: Rasmussen, L. B. et al: Dybdeboringen Rønde nr. 1 på Djursland. Danm. geol. Unders. III. Række, Nr. 39, pp. 9-32.

RASMUSSEN, L. BANKE, 1972: Oversigt over dybdeboringerne på dansk landområde 1965-68. - Dansk geol. Foren. Årsskrift for 1971, pp. 41-48.

Sorgenfrei, Th. \& A. Buch, 1964: Deep tests in Denmark 1935-1959. - Danm. geol. Unders. III Række, Nr. 36, 146 pp. 22 plates.

Sorgenfrei, Th., 1966: Strukturgeologischer Bau von Dänemark. - Geologie. Jhrg. 15, H. 6, pp. 641-660. Berlin. 


\title{
INTERPRETATION OF REFLECTION SEISMIC WORK IN THE AREA AROUND NØVLING NO. 1
}

\author{
by
}

\section{J. C. Baartman}

\section{INTRODUCTION}

For the interpretation of the reflection seismic work in the area around the deep test of Nøvling No. 1 all seismic profiles in this area were available.

The maps shown in figs. 7, 8, and 9 represent parts of a larger interpreted area, in which the best quality of data and the densest network of seismic lines were situated.

Some particulars of the reflection seismic work shown on the maps are the following:

a. Reflection data of lines marked "V" were analog recorded by Seismic Party No. 13 of the Danish American Prospecting Company in 1951-1953. In the period of 1952-1954 the D.A.P. Co. interpreted most of the cross sections of these lines and converted to depth.

b. Reflection data of lines marked "SV" were analog recorded by Shell Denmark Ltd. in 1963 and the seismograms were transcribed to a continuous variable density film.

c. Reflection shooting of lines marked "GH", "GS" and "GV" was also analog recorded, mainly by Seismograph Service Ltd., in the period of 1963-1967 for Gulf Oil Company of Denmark. S.S.L. also transcribed the seismic records to a variable density film.

The quality of the reflection data varied much in the area, but was generally good, especially in the area of the Danish Embayment. The most persistent reflected horizons were correlated along with more inconsistent ones. These horizons are:

1. "Base Tertiary": It was possible to carry the base of the Tertiary horizon, because it had a characteristic reflection, especially in deep zones. The velocity contrast is generally caused by the basal Tertiary shales and clays and the underlying Danian limestone (SorgenfreI, TH. \& Buch, A. 1964, pp. 13) (in the deep test of Nøvling respectively $2000 \mathrm{~m} / \mathrm{sec}$. and $3400 \mathrm{~m} / \mathrm{sec}$.). Correlations of the Base Tertiary horizon are considered to be reliable.

2. "Top Lower Cretaceous": The top of the Lower Cretaceous horizon reflection was of exceptionally good quality and was carried through the whole area. 




Fig. 7 


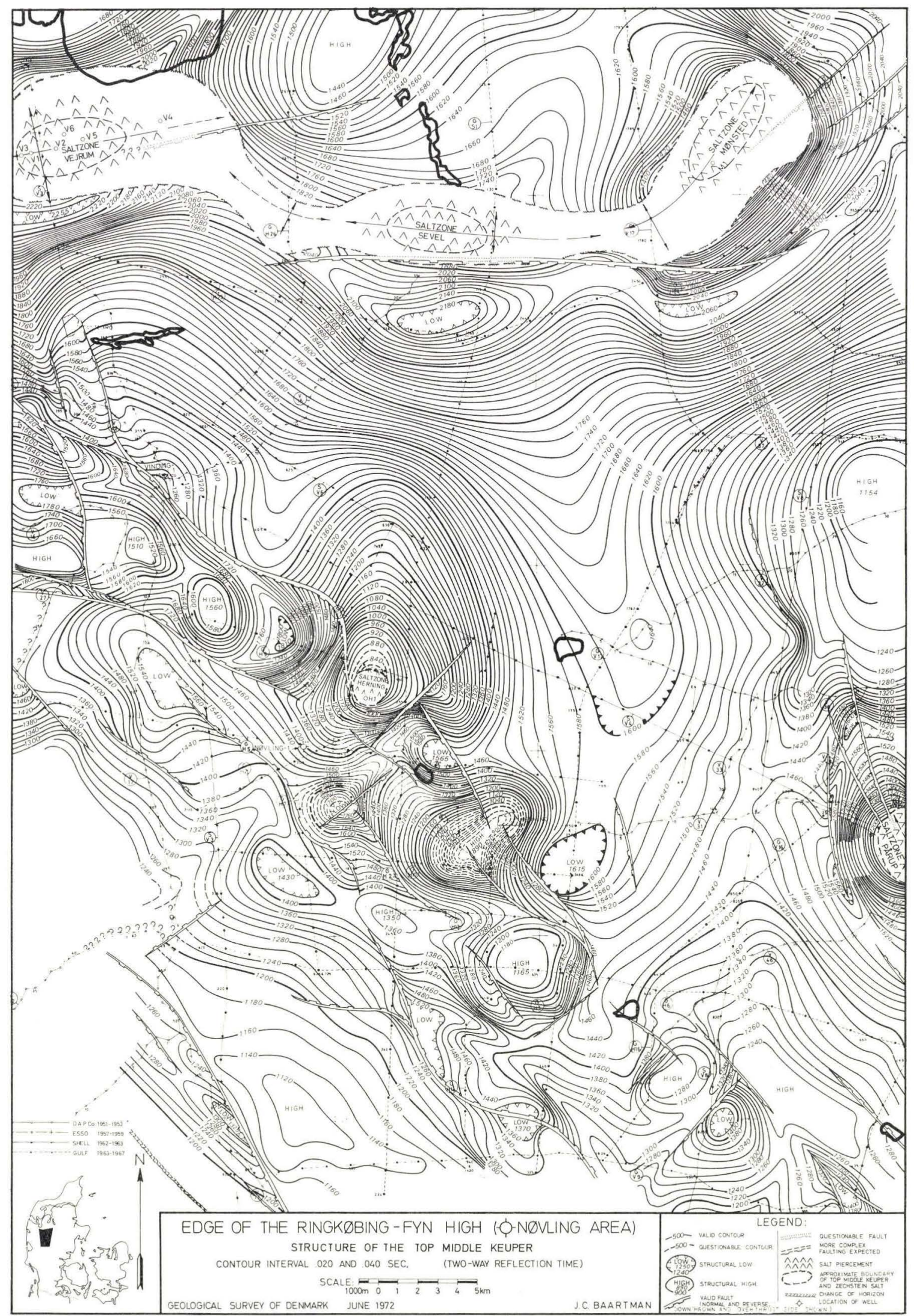

Fig. 8 


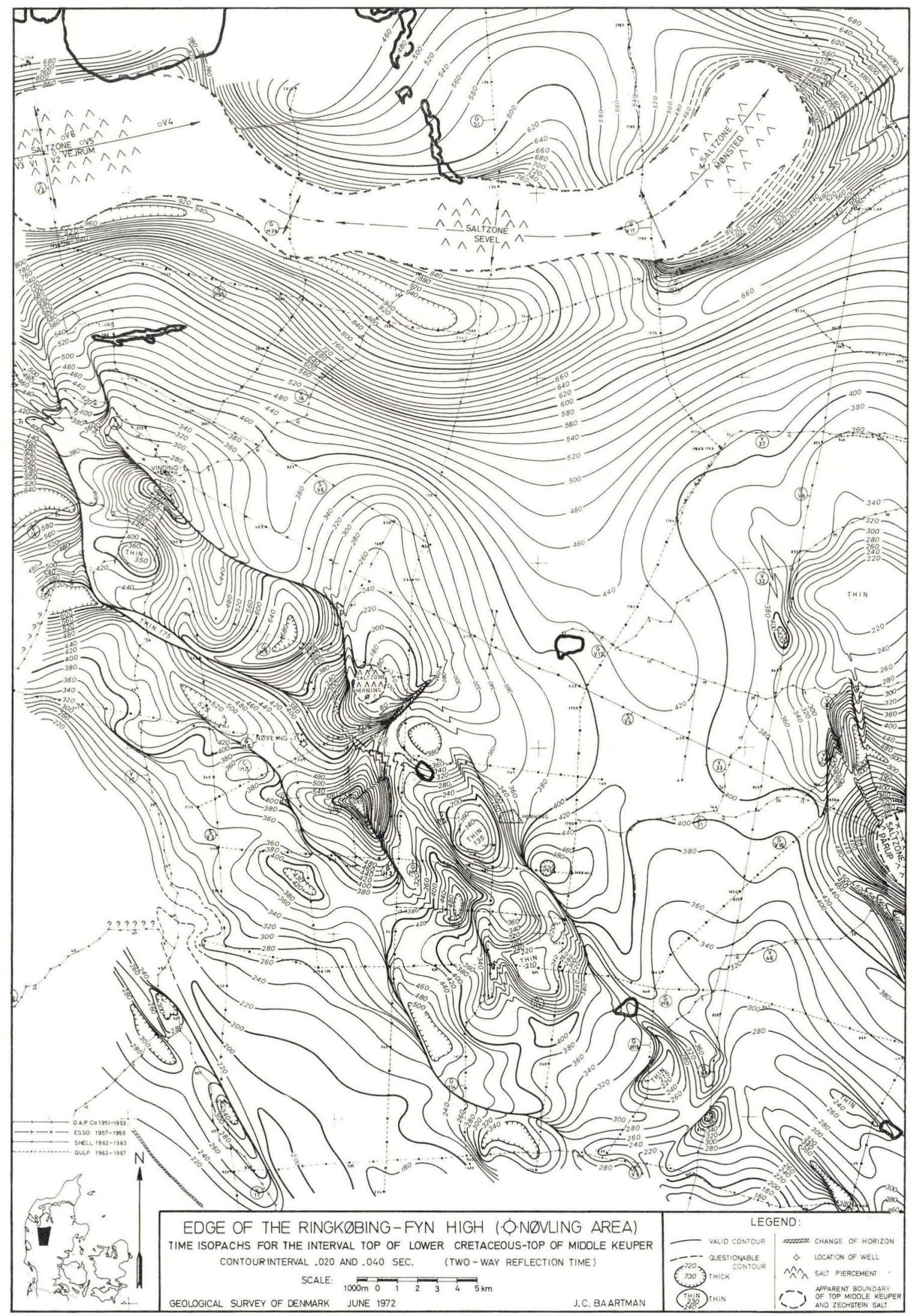

Fig. 9 
"Base Lower Cretaceous": An occasionally fair reflection near the base of the Lower Cretaceous, which has the character of a profound unconformity when it is recognized. This horizon is carried through the area wherever possible.

"Top Zechstein Dolomite": This horizon within the Zechstein section is recognized occasionally. It is presumed to be identical with the boundary between the Zechstein rock salt and the underlying dolomite of the oldest evaporite cycle.

The interpretation was controlled by the four deep tests of Vemb No. 1, Vinding No. 1, Nøvling No. 1 and Grindsted No. 1.

The Top Lower Cretaceous and Top Middle Keuper horizons were chosen for structure and isochrone mapping for the following reasons:

a. The quality of the reflections of these horizons was the best available, and their correlations should be considered reliable.

b. The major tectonic features outlined on the maps appeared to have been shaped by an orogeny, the main action of which came to an end at about late Jurassic time.

c. To illustrate the generalized configuration of the graben-type structures and the influence of pressure and shearing forces.

The contouring of the maps (figs. 7, 8, and 9) was guided by the shape of local gravity features, information of deep and shallow wells and local geological maps of the Danian (depth) and Tertiary (isopach). The structure maps were checked with existing similar maps of the same horizons.

In general, the correlation between the seismic and residual gravity anomalies was excellent throughout the area of interpretation.

The seismic time sections (figs. $6 \mathrm{a}$ and $6 \mathrm{~b}$ ) should not be interpreted like geological cross sections. Large changes in thickness of the Zechstein section with high interval velocities $(4400-7000 \mathrm{~m} / \mathrm{sec}$.) are the reasons why a depth section of the Base Zechstein may be different from a time section of the same horizon, especially in areas of salt doming.

The Top of Lower Cretaceous horizon could have been converted to depth, but the problem remained to assign accurate depth values to the Top Middle Keuper horizon from velocity information of deep tests. The velocity in the Jurassic section is considered to have changed considerably in regions of high basement uplift and the Danish Embayment. The velocity surveys between the wells were not available for interpretation.

\section{REGIONAL STRUCTURAL FRAMEWORK}

The area covered by the interpretation can be divided into the edge of the Ringkøbing-Fyn High in the SW, the Danish Embayment in the NE, the salt dome zones of Vejrum, Sevel and Mønsted in the $\mathrm{N}$ and the Herning and 
Pårup salt domes near the edge of the Danish Embayment (figs. 7 and 8). The attitude of the horizons in each of these regions is different.

The "Base Tertiary" horizon is relatively undisturbed in regions of high basement uplift (Ringkøbing-Fyn High). In this area the horizon is gently folded, it is generally unaffected by faulting and has a degree of concordance with the Top Lower Cretaceous. Towards the centre of the Embayment it gently follows the general fold directions where the folding of the Lower Cretaceous becomes stronger and the thickness of the underlying Upper Cretaceous chalk section increases (from about $780 \mathrm{~m}$ in the Nøvling well to about $1350 \mathrm{~m}$ in the Embayment). In the salt dome region the Upper Cretaceous section thins considerably towards the crest of the domes, thus showing active salt movement during Upper Cretaceous time. In a cross section of line SV-3 (over the Vejrum salt dome) the thickness of the Upper Cretaceous section reaches about $150 \mathrm{~m}$. Minor faulting of the Base Tertiary horizon occurs occasionally towards the crest of the major salt structures in the area.

Towards the centre of the Vejrum, Sevel and Mønsted salt domes the Base Tertiary horizon is too shallow to be carried, and it is supposed to crop out above the Vejrum dome.

The "Top Lower Cretaceous" horizon is rather undisturbed in the Ringkøbing-Fyn High area. In areas severely disturbed by tectonic movement the Lower Cretaceous section gently fills grabens and folds over horsts without being affected by minor faulting. Towards the centre of the Ringkøbing-Fyn High folding decreases even more. Towards the centre of the Embayment this horizon seems to be contorted in regions of severe salt movement. This deformation is supposed to have been caused primarily by salt tectonics. In areas of the Embayment, the Top Lower Cretaceous horizon is strongly folded compared with its undisturbed character in the Ringkøbing-Fyn High.

Where it was possible to carry the Top Zechstein horizon near the edge and towards the centre of the Danish Embayment there seemed to be a degree of concordance between the Top Lower Cretaceous and the Top Zechstein horizons in areas where the Upper Zechstein had a salt facies. This feature together with the strong folding in the Embayment area and the gentle folding in the area of high basement uplift of the Top Lower Cretaceous horizon and to a minor degree of the Base Tertiary horizon suggest that the basement has been more stable since Cretaceous time and that salt movement from the edge of the Embayment towards its centre has been active at least as late as Upper Cretaceous time. However, a good comparison between the Top Zechstein and the Top Lower Cretaceous horizons was not possible since the Near Top Zechstein horizon has not been mapped up to now.

The Top Lower Cretaceous horizon is present in cross sections of lines, mainly over the $\mathrm{N}$ flanks of the salt structures, but the Lower Cretaceous section is absent near the crest of the major salt domes of Vejrum, Mønsted and Pårup. 
A remarkable feature shows in profiles over the salt structures of Mønsted, Sevel and the E part of the Vejrum salt dome, where the Top Lower Cretaceous horizon is considerably shallower $\mathrm{N}$ of these domes. Coming from the $\mathrm{N}$, this horizon gently rises towards the centre of the domes and dips steeply (or is down-faulted) over the domes to the $\mathrm{S}$, reaching closures of about $1210 \mathrm{~m}$ and $1150 \mathrm{~m}$ over the Vejrum and the Sevel salt structures, respectively. In cross sections of lines situated between the gravity features of Mønsted, Sevel and Vejrum the closures of the Top Lower Cretaceous still reach about $830 \mathrm{~m}$ and $370 \mathrm{~m}$, respectively, which indicates a relatively high degree of salt movement between the Mønsted and Sevel domes.

In cross sections of lines bordering these salt zones parallel to their S flanks, the Zechstein interval remains fairly constant and thin over these sections. It appears that the salt flow into the domes is extended over the length of these sections.

The features of relatively high interdomal structures and a long thin Zechstein interval $\mathrm{S}$ of the flanks of the main salt structures indicate that a relation may exist between the Sevel and Mønsted salt domes and to a minor degree between the Vejrum and Sevel salt structures.

Where the Top Lower Cretaceous horizon reflection could be carried over the salt domes, the Lower Cretaceous section was thinning slightly towards the crest of the domes.

In some cross sections of lines intersecting the areas of subsidence near the flanks of salt structures, the Top Lower Cretaceous horizon was recognized together with an unconformity of Base Lower Cretaceous. The Lower Cretaceous sediments in these examples seemed only to be disturbed to a minor degree by salt tectonic movement.

\section{The "Base Lower Cretaceous" unconformity}

A profound unconformity near the base of the Lower Cretaceous is best recognized in areas of subsidence caused by salt tectonic movement in the Danish Embayment, but is also present elsewhere near the edge of the Embayment. While the Jurassic sediments follow the main trend of subsidence and are truncated by the unconformity, the Lower Cretaceous sediments are only affected to a minor extent by salt tectonic movement. The unconformity reflection was of less quality in examples of subsided areas around other salt structures than the Sevel salt dome.

\section{The "Top Middle Keuper"}

The reflection of this horizon was of good quality in undisturbed areas of the Danish Embayment. Near the edge of the Ringkøbing-Fyn High it was sometimes impossible to carry the Top Middle Keuper reflection for short intervals, which in my opinion was mainly due to faulting. 
In the Ringkøbing-Fyn High area the Top Middle Keuper horizon is already folded and is affected by most of the faulting. There were also observed some faults elsewhere in the Triassic of less than $40 \mathrm{~m}$ throw, only some of which may have been recognized. The steep dip of the Top Middle Keuper horizon and the much less disturbed Lower Cretaceous sediments indicate many pinchout and truncation possibilities of the Jurassic beds in the area near the edge of the Danish Embayment. Towards the centre of the Danish Embayment the Middle Keuper is even more folded than in the area of high Pre-Cambrian uplift.

During the interpretation it appeared that the effect of salt movement in areas of salt tectonics is best gathered from the attitude of the strong Top Middle Keuper reflection near salt structures.

On the S flanks of the Vejrum-Sevel-Mønsted salt domes and on the SW and NE flanks of the Pårup salt structure the Middle Keuper section has subsided, and it forms regional structural basins where the Zechstein salt reaches a minimum thickness. In one of these basins one cross section also shows truncated Jurassic beds where the Middle Keuper section reaches a maximum dip.

According to Trusheim (1960, pp. 1524 and 1528), structural basins in the NW German Salt Basin can be divided into "peripheral sinks" of different stages. "Primary peripheral sinks" are rim synclines caused by the displacement of salt into a salt pillow stage. When the accumulation of salt continues, breaking of the sedimentary overburden and rising of a diapir cause subsidence of surrounding sediments and a "secondary peripheral sink" is formed.

The first type of sinks is recognizable in the stratigraphic thickening away from the salt structures, while in secondary peripheral sinks the sedimentation is thickest closest to the diapir.

A primary peripheral sink $\mathrm{S}$ of the Vejrum salt dome is developed in strata of Keuper and a part of Lower Jurassic.

Conditions for peripheral sinking are very similar in cross sections of lines $\mathrm{S}$ of the Sevel and Mønsted domes, thus indicating that a relationship may exist between the magnitudes of salt movement into these domes.

At the Pårup salt structure the Keuper sediments slightly thicken away from both sides of the dome, while the Herning salt structure shows a primary peripheral sink (Keuper) on its NW flank.

Secondary peripheral sinks were less pronounced. $\mathrm{S}$ of the Vejrum salt dome a secondary peripheral sink of Middle and Upper Jurassic age may be present.

A point of interest is that $\mathrm{N}$ of the flanks of salt structures in the area of interpretation, where the Zechstein section reaches a greater thickness than on the S sides, the Top Middle Keuper horizon is generally shallower, and subsidence together with sedimentation has not resulted in the forming of deep structural basins. 
This feature is considered to be related to the main salt flowage from the edge of the Danish Embayment towards its centre. However, an exception must be made for the Parrup salt dome, where the Top Middle Keuper horizon seems to be equally affected by salt tectonic movement in profiles NE and SW of this structure. The effect of a salt flow to the NNE is different in this case, according with the NNW-SSE trend of this salt dome.

Interesting is the fact that the Middle Keuper is absent for a major part in the Vejrum, Sevel and Mønsted salt domes. In three sections of lines crossing these domes in a $\mathrm{N}-\mathrm{S}$ direction, the total length of the folded Top Middle Keuper horizon on both sides of the doming was compared with the length of a continuous flat model of the same reflection over the same distance, in an attempt to compare the effect of salt tectonic movement and minor faulting within the Triassic, near these domes. It appeared that especially in the Vejrum salt dome the zone of absence, as it could be correlated from seismic data, was too long. However, this leaves the question if in this region the Middle Keuper and the Rhaetic sediments were originally present, later being removed by erosion caused by the upward rise of the salt dome. It is also possible that these beds were not deposited because the domes already existed at these times (LARSEN, G. 1966, pp. 101).

In one cross section of a N-S line, showing the area of subsidence $\mathrm{S}$ of the Sevel salt dome, the Lower Jurassic sediments and possibly a part of the Rhaetic (?) beds are truncated by the unconformity near the base of the Lower Cretaceous. Other examples of Rhaetic, capped by Lower Jurassic beds, which are truncated by the Lower Cretaceous unconformity are known elsewhere in Denmark. This feature and the long distance of absence of the Middle Keuper near the salt domes of Vejrum, Sevel and Mønsted indicate that both non-deposition and erosion may have been partly responsible. However, upward rise of the salt dome and non-deposition may well have been the most important factors.

\section{The "Near Top Zechstein"}

The reflection caused by this horizon was of fair quality in cross sections of most of the dip-lines in the Danish Embayment and could be carried through in sections of E-W lines. In the Ringkøbing-Fyn High area this horizon was difficult to correlate in zones of severe faulting. In areas of salt doming it was possible to carry the Near Top Zechstein reflection to near the base of the doming, so that exact closures could not be measured, but were estimated from the closures of the Top Lower Cretaceous horizon, the attitudes of the Top Middle Keuper horizon and an occasionally recognized reflection of the unconformity at the base of the Lower Cretaceous. Considering these factors, the Vejrum and Pårup salt structures seem to reach considerable closures.

A point of interest is that the Zechstein interval thins near the edge of the 
Danish Embayment, where it has predominantly a salt facies, and shows a certain degree of thickening towards the centre of the Ringkøbing-Fyn High, where it has mainly a dolomite and anhydrite facies. Further SSW the Zechstein section thins considerably.

In the Danish Embayment the Zechstein thickness reaches about $1250 \mathrm{~m}$ and is expected to be even thicker between line GS-1 and line GV-17. Towards the base of the S flanks of the salt domes Vejrum, Sevel and Mønsted the Zechstein interval decreases over the length of cross sections of the E-W lines GH-25 and the $\mathrm{W}$ half of GH-24, where the thickness of a more or less constant, thin Zechstein interval varies around $340 \mathrm{~m}$.

The Zechstein section $\mathrm{N}$ of the flanks of the salt structures, situated near the edge of and in the Danish Embayment, has a tendency to be thicker than S of the flanks, but an exception must be made for the Pårup salt structure, where the Zechstein salt is more equally spread around the dome.

This increase of the Zechstein interval $\mathrm{N}$ of the salt structures is partly due to a down-faulting of the Base Zechstein to the $\mathrm{N}$, which is recognized in some seismic profiles crossing the Vejrum and Sevel salt domes and interdomal highs between the Vejrum-Sevel and Mønsted-Sevel salt domes.

These features of considerable thickening of the Zechstein towards the centre of the Embayment before reaching the structures of Vejrum-Sevel-Mønsted, the relatively thin Zechstein section at the edge of the Danish Embayment, and the general thickening of the Zechstein on the $\mathrm{N}$ flanks of these salt structures indicate a salt flowage from the edge of the Danish Embayment towards its centre. The same salt flowage direction also prevailed during the salt piercement movements. It is known, however, that during the sedimentation of the Permian salt, the Base Zechstein moved downwards in the central area of the Danish Embayment, thus causing favourable conditions for a thick salt sequence in this area. At the same time an uplift of the Base Zechstein may be expected in the Ringkøbing-Fyn High. The salt flowage from the edge of the Ringkøbing-Fyn High towards the central area of the Embayment was therefore restricted to the edge of the Danish Embayment. This $\mathrm{N}$ direction of salt flowage is reasonable in view of the fact that except for the existing piercement domes in the North Jutland Salt Basin also two deep-seated small salt structures could be observed.

The long, thin Zechstein interval at the base of the S flanks of the Sevel and Mønsted salt structures and the still considerable closures of interdomal highs between these domes may indicate a relationship between the mechanisms of salt piercement of the Sevel and Mønsted salt structures.

Some cross sections over salt domes outlining the general shape of the doming were available. It appears that the salt structures are more or less asymmetric, except for the Pårup salt dome. The Vejrum salt dome shows a small overhang near its crest to the S, and both this dome and the Sevel and Mønsted domes seem to dip steeper on the S flanks. 
In two cross sections over the flanks of the Herning structure two faults were recognized. The lengthy shape of this dome seems to be slightly tilted parallel with one of these faults. This fault must have affected the Zechstein section. Geological information at hand suggests the presence of a salt dyke, but it was impossible to outline the exact shape of this salt structure. However, the structural pattern of doming and faulting resembles an example of an early stage of a diapir in the North West German Salt Basin (Trusherm, F. 1960, pp. 1527).

Well logs of the Herning No. 1 well report large quantities of gypsum found at $60 \mathrm{~m}$ depth, descended from caprock. However, in two cross sections of lines intersecting the structure close to its crest the Top Lower Cretaceous and a large part of the Top Middle Keuper horizons are present over the salt structure, but are affected by one of the two faults mentioned, which also seems to have affected the Base Tertiary horizon.

Considering the elongated shape of the diapir, which is extruded from a salt pillow, and the faulting extending into the NW flank of the diapir, salt escape via this fault seems plausible.

In general it is assumed that salt movement in the basin area has been an active tectonic force at least since the Keuper period through early Tertiary time.

\section{The "Base Zechstein"}

The Base Zechstein is in general the deepest reflected horizon which is of good quality in areas with a thick salt sequence. Faults have affected the Base Zechstein primarily in the areas of high basement uplift and occur in the Danish Embayment mainly in areas of salt tectonic movement.

In some sections of lines intersecting the Vejrum, Sevel and Mønsted domes and interdomal highs, Base Zechstein faults are recognized which may be related to each other. These faults are dipping $\mathrm{N}$ and have a similar character. Faulting of the Base Zechstein may also occur in the Herning structure.

Whether faulting or folding which affected this horizon may have had a triggering effect upon the initial movement of the salt into the structures is difficult to judge. Other examples of salt structures are known elsewhere in the Danish Embayment where no faulting of the Base Zechstein horizon has been recognized. The feature of anticlinal folding of the Base Zechstein horizon in time cross sections may be misleading. Lateral changes in average velocities to the Base Zechstein horizon in areas with high velocity salt domes may cause an anticline of the Base Zechstein in time sections to be synclinal in depth sections. However, also in two other deep-seated, small salt structures in the area of interpretation, faulting of the Base Zechstein has occurred. 


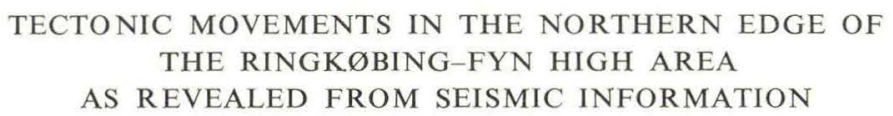

The faults in the area around the Nøvling well are correlated in respect to throw (the amount of displacement), steepness of dip, and character (the number of affected horizons and their interval relation on both sides of the fault).

In areas of strong faulting the Top Middle Keuper reflection is poor, so that the throw had to be estimated in some instances.

On the basis of this correlation three different types of faulting are recognized:

1. The NW-SE to NNW-SSE striking fault system (the correlation of this type of faulting should be considered to be reliable).

2. The NE-SW striking faulting.

3. The fault system related to salt tectonic movements in and near the edge of the Danish Embayment, whose direction is depending on the character of salt flowage and piercement.

It is plausible to compare the directions of the main fault systems with old tectonic trends in N Europe (e.g. in the Fennoscandian Border Zone).

The SW-NE direction is parallel with old trends of the Caledonian movements in NW-Europe.

A SW-NE direction is also found together with SE-NW tectonic trends in the Variscan orogeny of Central Europe. In the Fennoscandian Border Zone, extending from the Vendsyssel High (North Jutland) via Scania (South Sweden) to the island of Bornholm (Baltic Sea), the main direction of fractured zones is NW-SE. Structural movements must have had a considerable influence in this area. Horizontal forces produced stresses and tensions as well as vertical adjustments.

Finally a NNW-SSE to N-S direction has been developed since Jurassic time in Central Europe, mainly in the Tertiary period.

The regional strike direction in the Ringkøbing-Fyn High is supposed to be NW-SE. Basement uplift was initiated before Permian time, and it is suggested that the upward movement coincides with the Variscan (or possibly already the Caledonian) orogeny (Sorgenfrei, TH. \& Buch, A. 1964, pp. 24).

In order to determine the main period of fault activity in the Ringkøbing-Fyn High area with the help of the interval relation of reflected horizons on both sides of the faulting, three horizons carried through the faulted zones could be used together with an occasionally strong reflection of Lower Triassic age.

1. The NW-SE to NNW-SSE striking faults which intersect the edge of the Ringkøbing-Fyn High form the borders of an "en échelon"-type of structures (figs. 7 and 8). Some grabens have arisen from higher horsts and are sometimes 
strongly tilted (figs. 6a and 6b). Most of the faulting of this type is normal, but there are two examples of overthrusts in the area. The faults are in many cases more or less curved, rather than straight dipping. This feature, together with the deviation in the direction of the structures from the regional NW-SE trend of the Ringkøbing-Fyn High, is explained as an "en échelon" arrangement of the blocks, due to horizontal movements along NW-SE trending wrench faults.

A point of interest is that the graben-type faulting tends to occur near the edge of the Danish Embayment. Geological information and seismic evidence on cross sections of three $\mathrm{N}-\mathrm{S}$ lines suggest that the Zechstein section has slumped into the graben structures (where it has a salt facies) as a result of salt flowage from the edge of the Ringkøbing-Fyn High towards the centre of the North Jutland Salt Basin. It is assumed that salt flowage may have played only a small part in the movement which resulted in the forming of grabens near the edge of the High, since in this area the Zechstein section has mainly a dolomite and anhydrite facies.

The tectonic development in the Ringkøbing-Fyn High can be explained by two of these NW-SE striking faults. Also in two other examples of similar faulting of inferior quality, a relationship seems to exist between the Base Tertiary, the Top Lower Cretaceous and the Top Middle Keuper time intervals on the upthrown and downthrown sides of these faults. Two examples of faults intersecting a reflected horizon of Lower Triassic age were present, showing the same feature. Since the interval velocities on both sides of the faults are expected to be related to each other, both the deep character recognized in some of the faults and the relationship between time intervals indicate a continuity of tectonic movement during long periods and at least during a major part of the Triassic.

The Lower Cretaceous sediments are affected by only some of these faults. In other areas of the Ringkøbing-Fyn High there is evidence that this section has been influenced by structural movements.

The Upper Cretaceous sediments, predominantly limestone and chalk, seem to follow the same structural pattern as the Top Lower Cretaceous. It is not evident to what extent the Upper Cretaceous section has been affected by structural movement, because of its thickness and the lack of a reflecting horizon within this section. In a cross section of line GH-9, fault movement has reached at least as far as Paleocene time. Apparently, vertical movements of the blocks continued during most of the Triassic through early Tertiary times.

In summary, it appears that the major tectonic features which are outlined in the regional maps (figs. 7, 8 and 9) have been formed by an orogeny, the main action of which ended at about late Jurassic time, since geologic and seismic information indicate a major reduction of Pre-Cretaceous rocks in the area of high basement uplift. Jurassic deposits are expected to be absent near 
the centre of the High, while the Lower Cretaceous section is also thinning towards the SW in the area of interpretation.

2. The NE-SW faulting system differs from the NW-SE type of faulting in relation to the facts that in general these faults dip steeper, cause less displacement of the Top Middle Keuper horizon and affect the Top Lower Cretaceous horizon only in two instances in this area.

In cross sections of two $\mathrm{N}-\mathrm{S}$ lines this type of faulting has been recognized together with a good reflected horizon of Lower Triassic age (this horizon has been carried through the edge of the Ringkøbing-Fyn High area where possible). In both of these cross sections it appears that the Lower Triassic horizon is displaced by faulting to a larger extent than the younger Top Middle Keuper horizon.

On the basis of this feature and the relatively undisturbed Top Lower Cretaceous horizon it is concluded that this type of faulting may be extended into older formations within the Triassic or even Zechstein. On two occasions where the Near Top Zechstein reflection was of fair quality it is assumed that this type of faulting has affected the Zechstein salt.

A comparison of intervals of horizons on both sides of this faulting including the Top Lower Cretaceous-Top Middle Keuper interval was not possible as only two faults of this type have affected the Top Lower Cretaceous horizon. In one occasion this resulted in a displacement of the Lower Cretaceous to a minor extent. In the other case the faulting has been affected by salt movement which resulted in the Herning structure.

In comparing this type of faulting and the NW-SE striking fault system it can be said that the main period of action of the NE-SW faulting is considered to be older. Most of the NE-SW striking faults are related to minor structures (figs. 3 and 4).

\section{The fault systems near the flanks of and over the salt structures.}

These fault systems can be divided into two groups:

a. Faulting caused by salt movement, subsidence of areas surrounding the salt structures and a steady supply of sediments into the subsided regions.

b. Faulting which is mainly caused by vertical forces which were necessary for salt uplift.

Both types of faulting are related to salt tectonics.

The first type of faulting is recognized in the area by the displacement of the strongly reflecting Top Middle Keuper horizon.

These faults have a tendency to be downthrown towards the flanks of the salt structures and are gently dipping.

On the S flanks of the Sevel and Mønsted salt domes, where subsidence 
resulted in the forming of basins, the Lower Cretaceous and Jurassic sections reach a thicknesses of respectively about $880 \mathrm{~m}$ and $670 \mathrm{~m}$, whereas the same section is only $450 \mathrm{~m}$ thick in the faulted area SW of the Pårup dome. Conditions for the formation of a thick sedimentary sequence were apparently not present at Pårup, while longlasting and strong subsidence of the basin area and a supply of sedimentary materials have prevailed $\mathrm{S}$ of the Sevel and Mønsted salt domes and SE of the Herning dome. However, the faulting in the subsided areas around Pårup is of a different character than the similar type of faulting at the Herning and Sevel-Mønsted domes, because here the basin is shallow and strongly tilted upward towards the salt structure. In this example the effect of vertical forces which were necessary for salt uplift has been more important than the effect of sedimentation.

Faults of the second type, situated near the flanks or over the salt structures, could not be correlated. Therefore these faults were merely mapped with the help of information of similar faulting related to salt structures in the North West German Salt Basin and by the attitude of the Zechstein salt interval on the flanks of the structures.

DANSK SAMMENDRAG

\section{FORTOLKNING AF REFLEKTIONSSEISMISKE ARBEJDER I OMRÅDET OMKRING NØVLING NR. 1}

De reflektionsseismiske arbejder i området omkring dybdeboringen Nøvling nr. 1 er udført af Danish American Prospecting Co. (1951-1953), Dansk Esso A/S (1957-1959), Shell Denmark Ltd. (1962-1963) og Gulf Oil Co. of Denmark (1963-1967). Seismogrammerne foreligger i almindelighed i analog form og blev i 1958 transskriberet til VDF-type (Variable Density Film).

De mest gennemgående horisonter indenfor det fortolkede område var følgende :

$»$ Basistertiar «. Reflektionen fra denne horisont skyldes i almindelighed en hastighedsforskel mellem sedimenterne, som bestod af skiferler og ler ved basis af de paleocæne lag og en underliggende kalksten af danien alder. Reflektionen var af god kvalitet i de dybere zoner.

»Top nedre kridt «. Denne reflektion var af usædvanlig god kvalitet. Horisonten ligger i almindelighed lidt over grænsen mellem kalksten af øvre kretacisk alder og nedre kretacisk lersten.

»Top mellem keuper «. Denne horisont forårsagede en mindre konstant, men kraftig reflektion og anses for praktisk taget identisk med grænsefladen mellem rhaetisk skiferler og sand og de underliggende lag fra mellem keuper, bestående af lersten og mergelsten. 
$»$ Nar top zechstein «. Reflektionen fra denne horisont skyldes i almindelighed en hastighedsforskel mellem buntsandstein (sandsten og siltsten) og det underliggende zechstein stensalt. Horisonten kaldes »nær top zechstein «, fordi der i Nøvling boringen kun forekommer et ganske tyndt interval af lag fra zechstein med store lydhastigheder og fordi reflektionen er af dårlig kvalitet $\mathrm{i}$ det forkastningsprægede område omkring denne boring.

»Basis zechstein«. I Nøvling boringen skyldes denne reflektion en hastighedsforskel mellem det nederste zechsteins dolomit/anhydrit og silurets hårde lag af lerskifer, sandsten (og kalksten). Horisonten regnes for at ligge nær zechsteins basis, men kan ikke lokaliseres nærmere, da resultaterne af boringens seismiske lydhastighedsundersøgelse muligvis ikke er fuldt sikre for denne dybde.

Mindre sikre horisonter er følgende:

$»$ Basis nedre kridt «. Denne reflektionshorisont er observeret hist og her og har karakter af en diskordans.

$» T o p$ zechstein dolomit «. Denne horisont anses for at være identisk med grænsen mellem zechstein stensaltet og den underliggende dolomit fra den ældste evaporit-cyklus indenfor zechsteinserien.

Strukturerne og isopakerne for »top nedre kridt« og »top mellem keuper « horisonterne (se fig. 7 og 8) er først og fremmest kortlagt for at skaffe et overblik over virkningen af de vigtigste tektoniske bevægelser, der synes at være tilknyttet en orogenese hvis væsentligste aktivitet sluttede i sen-jurassisk tid.

Det fortolkede område (vist på fig. 7, 8 og 9) kan deles i randområdet af Ringkøbing-Fyn Højderyggen mod sydvest, det Danske Sænkningsområde mod nordøst, saltdome-områderne ved Vejrum, Sevel og Mønsted mod nord, samt Herning og Pårup saltdomerne nær randen af det Danske Sænkningsområde.

De strukturelle forhold for de forskellige reflektionshorisonter er forskellige for hvert af disse områder.

»Basis tertiar « og i mindre grad »top nedre kridt « horisonterne er forholdsvis uforstyrrede i området med hævet grundfjeld (Ringkøbing-Fyn Højderyggen), men foldningen bliver stærkere i det Danske Sænkningsområde. Det faktum, at top nedre kridt horisonten er svagt foldet i områder med højtliggende grundfjeld og stærkere foldet i saltbassinet (det Danske Sænkningsområde), antyder at grundfjeldet har været relativt stabilt lige siden kridttiden. Nedre- og især øvre kridt afsnittene bliver tykkere i retning mod saltdomernes midtlinier, hvilket viser, at saltet har været $\mathrm{i}$ aktiv bevægelse $\mathrm{i}$ det mindste så sent som $\mathrm{i}$ øre kretacisk tid.

»Basis nedre kridt « diskordansen kunne nu og da observeres i indsynknings- 
områderne omkring saltstrukturerne i det Danske Sænkningsområde. Rhaet(?) og jura lagene følger sænkningsområdets hovedkonturer og afskæres af diskordansen ved basis af nedre kridt, hvorimod nedre kridt afsnittet kun i ringe grad er forstyrret af sænkningen.

»Top mellem keuper « horisonten er stærkere foldet i området med højtliggende prækambrium end top nedre kridt horisonten er, og den er blevet påvirket af de fleste af forkastningsbegivenhederne. Foldningsintensiteten øger ud mod sænkningsområdet. Den stærkere foldning af mellem keuper sedimenterne og de meget mindre forstyrrede nedre kridt lag tyder på, at der foreligger mange muligheder for udkilning og afskæring af de jurassiske lag i området nær kanten af det Danske Sænkningsområde. Juraintervallet bliver betydeligt tyndere mod sydvest i dette område.

Mellem keuper og jura lagene er nedsunket i områderne grænsende op til saltstrukturerne, og nedsynkningen har resulteret i udformningen af strukturelle bassiner syd for Vejrum, Sevel og Mønsted strukturerne og sydøst for Herning strukturen.

Syd for Vejrum saltdomen er sedimenterne fra nedre jura og muligvis også rhaet(?) afskåret af diskordansen ved basis af nedre kridt. Dette peger hen på, at den ret lange strækning, hvor »top mellem keuper « horisonten mangler over Vejrum, Sevel og Mønsted domerne, både kan skyldes manglende sedimentation og erosion. Aflejring af mellem keuper lag har muligvis ikke fundet sted på toppen af domerne, og afsatte lag på domernes flanker kan være borteroderet.

»Zechstein « intervallet tynder ud nær randen af det Danske Sænkningsområde og bliver noget tykkere ind mod de centrale dele af Ringkøbing-Fyn Højdeområdet, medens udtyndingen yderligere mod SSV er betydelig. Ud mod sænkningsområdet når dette interval en betydelig tykkelse $(1250 \mathrm{~m}) \mathrm{og}$ tynder ud ved basis af Vejrum, Sevel og Mønsted saltdomernes sydflanker, hvor et tyndt zechstein interval varierer omkring $340 \mathrm{~m}$.

Der er en tendens til, at zechstein intervallet bliver tykkere nord for saltstrukturerne, undtagen for Pårup domens vedkommende.

Disse træk indicerer en saltbevægelse fra randen af det Danske Sænkningsområde ind mod dets centrale dele. Denne saltbevægelse indskrænker sig imidlertid til sænkningens randområde.

Ligheden mellem betingelserne for »perifer indsynkning « (TRUSHeIM, F. 1960, pp. 1524 og 1528) for de nedsænkede områder syd for Sevel og Mønsted saltdomerne peger hen på, at der muligvis kan være et bestemt forhold mellem størrelsen af saltbevægelsen i disse domer.

Det synes sandsynligt, at der en saltvæg ved Herning saltdomen.

Saltbevægelsen i sænkningsområdet har været aktiv muligvis siden trias og i det mindste så sent som i øvre kretacisk tid.

4 * 
»Basis zechstein « horisonten er forkastet først og fremmest i området med højtliggende grundfjeld, medens forkastninger i det Danske Sænkningsområde hovedsagelig forekommer i de salttektoniske bevægelsesområder.

Det er muligt, at forkastninger eller foldning af denne horisont har påvirket den indledende bevægelse af saltet ved dannelsen af saltdomerne.

De tektoniske bevægelser i området er undersøgt med hensyn til de gamle forkastningssystemer i Nordeuropa. Tre forskellige forkastningssystemer kan observeres (se fig. 8 og 9): De NV-S $\varnothing$ til NNV-SS $\varnothing$ strygende forkastninger, de NØ-SV strygende forkastninger og et forkastningssystem der er forbundet med de salttektoniske bevægelser.

De NV-SØ til NNV-SS $\varnothing$ strygende forkastninger udgør det vigtigste forkastningssystem. Disse forkastninger afgrænser en række »en échelon « blokke.

Forholdet mellem lagseriernes tykkelser på de to sider af en forkastning af denne type peger på en kontinuerlig tektonisk bevægelse over længere tidsrum. Det antages, at de vigtigste tektoniske træk der følger af disse forkastninger, er virkninger af en orogen aktivitet der hovedsagelig har fundet sted i et tidsrum sluttende sent $\mathrm{i}$ juraperioden.

Forkastningerne med strygning NØ-SV danner et system, der adskiller sig fra de NV-SØ-gående forkastninger ved at disse sidstnæunte må have forskudt de ældre formationer. På grund af mangelen på dybtliggende horisonter påvirket af disse $\mathrm{N} \varnothing-\mathrm{SV}$ forkastninger har det ikke været muligt at foretage en nøjagtig sammenligning mellem lagserier på de to sider af forkastningerne i dette system.

Imidlertid anses NØ-SV forkastningernes hovedsagelige aktivitetsperiode at have været af ældre dato end jura.

Forkastningssystemet med tilknytning til saltstrukturerne kan deles i to typer, nemlig forkastninger forårsaget af indsynkning af områderne omkring saltstrukturerne og tilførslen af sedimenter til disse områder, og forkastninger forårsaget af de vertikale kræfter som var nødvendige for oppresningen af saltet.

\section{LITERATURE}

Brockhaus, F. A., 1961. Die Entwicklungsgeschichte der Erde. - F. A. Brockhaus Verlag, pp. 173-184. - Leipzig.

Casten, U. \& Hirschleber, H., 1971. Seismic Measurements in Jutland 1969. - Zeitschrift für Geophysik, Bd. 37, pp. 47-69. - Würzburg.

Larsen, G., 1966. Rhaetic-Jurassic-Lower Cretaceous Sediments in the Danish Embayment. - Danm. geol. Unders., II række, nr. 91. - København.

Madirazza, I., 1968. Mønsted and Sevel salt domes, North Jutland, and their influence on the Quaternary morphology. - Geol. Rdsch., Bd. 57, pp. 1034-1065. - Stuttgart.

- 1968. An Interpretation of the Quaternary morphology in the Pårup salt dome area. Meddr dansk geol. Foren., Bd. 18, Hæfte 2, pp. 241-243. - København.

Noe-Nygaard, A., 1963. The Precambrian. - The Geologic Systems, Vol. 1. - København. 
Ødum, H., 1960. Saltefterforskningen i Danmark. - Danm. geol. Unders., III række, nr. 34, 43 p. - Kobenhavn.

Ramberg, Ivar B. and Lind, G., 1968. Gravity measurements on the Pårup saltdome. Meddr dansk geol. Foren., Bd. 18, Hæfte 2, pp. 221-239. - København.

Sannemann, D., 1968. "Salt Stock Families in Northwestern Germany", in Diapirism and Diapirs, A Symposium. - Amer. Ass. Petrol. Geol., Mem. 8, pp. 261-270. - Tulsa, Okla.

Sorgenfrei, Th., 1966. Strukturgeologischer Bau von Dänemark. - Zeitschrift »Geologie«, Jahrgang 15, Heft 6, pp. 641-660. - Berlin.

- 1968. Jura und Unterkreide in Dänemark. - Z.dt. geol. Ges., Bd. 114, 2. Teil, pp. 446451. - Hannover.

- 1969. Geological Perspectives in the North Sea Area. - Meddr dansk geol. Foren., Bd. 19, Hæfte 2, pp. 160-189. - København.

- \& BuCH, A., 1964. Deep Tests in Denmark 1935-1959. - Danm. geol. Unders., III række, nr. 36, pp. 9-146. - København.

Trusheim, F., 1960. Mechanism of salt migration in Northern Germany. - Amer. Ass. Petrol. Geol., Vol. 44, nr. 9, pp. 1519-1539. - Hannover. 


\section{BESTEMMELSE AF BOREHULSAFVIGELSER, LAGHÆLDNINGER OG TEMPERATURGRADIENT I NØVLING NR. 1}

af

Svend E. Henriksen

\section{NØVLING BORINGENS AFVIGELSE FRA LODLINIEN}

Grundlaget for beregningen af boringens retning er - ligesom for boringen Rønde nr. 1 - kontinuerlige målinger med »continuous dipmeter« og enkeltmålinger med »drift indicator«.

Beregningerne af retningens deviation og azimuth er udført på nøjagtig samme måde som for Rønde nr. 1 (se DGU, III. rk., nr. 39, p. 35). For afsnittet 0-1070 m, fra hvilket der ikke foreligger »continuous-dipmeter« målinger, er de sandsynlige værdier af deviation og azimuth fundet ved en matematisk korrektions- og interpolationsproces ud fra »drift-indicator « værdierne. Disse var også i denne boring for små i forhold til de tilsvarende dipmetermålinger.

Boringens retning er vist grafisk i fig. 10 for afsnittet 1070-3759 m (under KB), medens fig. 11 viser dybdekorrektionen, som anvendes til omregning fra boredybde (i m under KB) til kote.

Endvidere viser fig. 12 boringens horisontalprojektion. Den magnetiske deklination er $3^{\circ} \mathrm{W}$. Afsnittet $0-1070 \mathrm{~m}$ er angivet med stiplet linie.

Desuden ser man på fig. 13 en vertikalprojektion på et plan i retningen N-S. Den er konstrueret ud fra fig. 11 og 12.

\section{BESTEMMELSE AF LAGHÆLDNINGER}

Også beregningen af laghældningerne følger samme princip som for Rønde nr. 1. I Nøvling nr. 1 er de udført for ialt 437 punkter (lag) i afsnittene 1070 1159 m, 1250-1551 m, 1691-1692 m, 1837-2101 m, 2186-2222 m, 2250-2425 m, 2485-2486 m, 2635-2741 m, 2818-3266 m, 3291-3292 m, 3300-3351 m, 3390$3431 \mathrm{~m}$ og 3454-3759 m.

Resultaterne af beregningen er vist i tabel 1. Her er lagenes stilling angivet dels ved laghældningen og dennes retning (azimuth fra magnetisk nord) og dels ved strygning (i forhold til geografisk nord) og hældning. Azimuth og strygning er hver for sig afrundet til nærmeste $10^{\circ}$, medens hældningen er angivet til nærmeste hele grad.

Resultaterne i tabel 1 kan sammenfattes til følgende hovedresultater: 


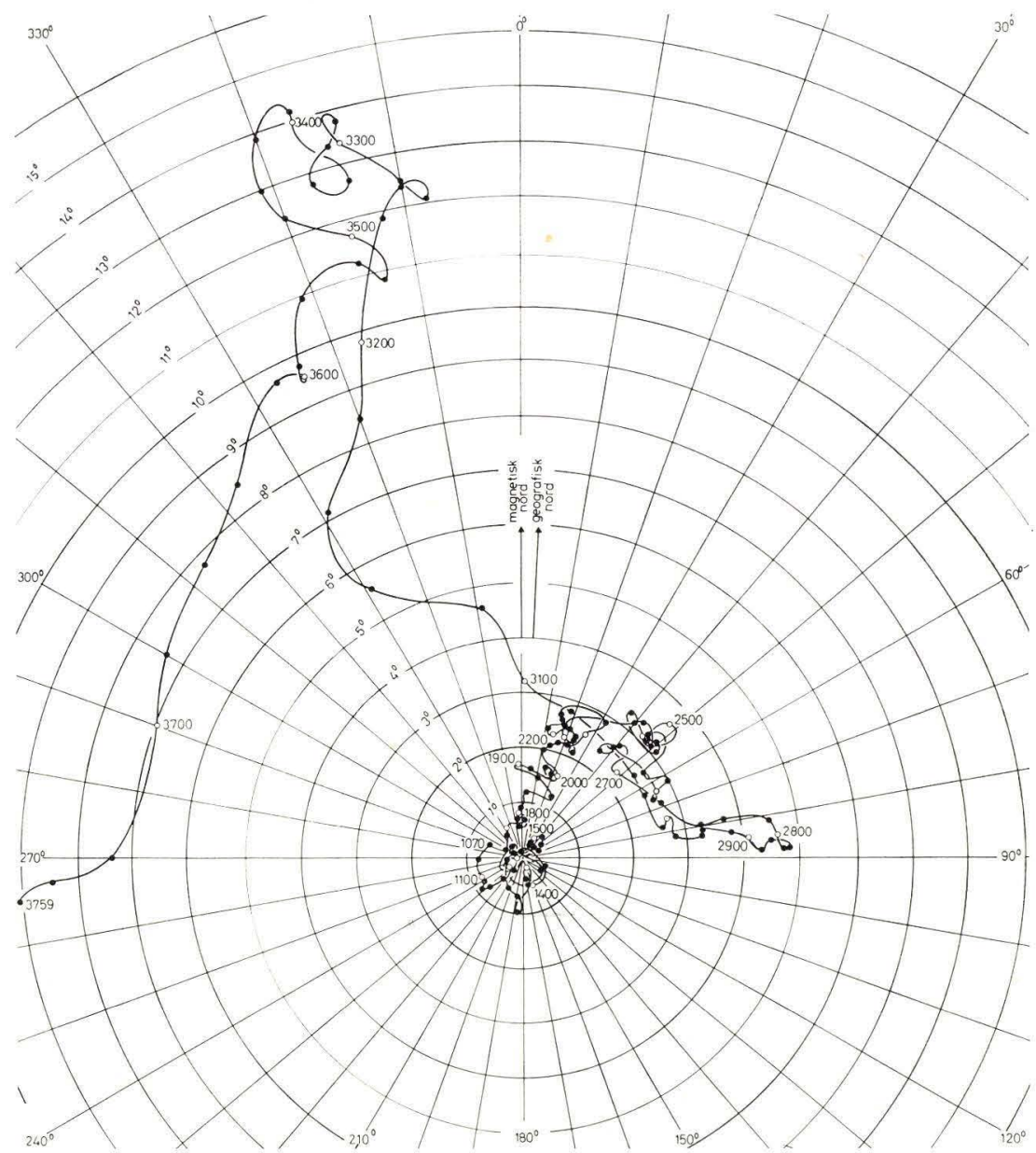

Fig. 10. Boringens retning, indtegnet på polærpapir.

The direction of the drilling at any point, plotted on polar paper.

1259-1492 m (nederste del af øvre kridt og det meste af nedre kridt) omkring $2^{\circ} \bmod \varnothing$, med ringe variation

1847-2060 m (rhæt og øverste keuper) omkring $4^{\circ}$ mod SW, med ringe variation

2359-2411 $\mathrm{m}$ (en del af keuper) $8^{\circ} \bmod \mathrm{WSW}$, med ringe variation

2832-2976 m (en del af muschelkalk) $4^{\circ} \bmod \mathrm{WNW}$, med ringe variation

2999-3259 m (en del af muschelkalk) gradvis ændring nedefter fra $11^{\circ} \bmod \mathrm{S}$ til $40^{\circ} \bmod \mathrm{S}$

3315-3338 m (en del af buntsandstein) ca. 13 mod N; denne måling repræsenterer formodentlig ikke en laghældning

3537-3688 m (øverste del af øvre silur) gradvis ændring nedefter fra $35^{\circ} \mathrm{mod}$ $\varnothing \mathrm{N} \varnothing$ til $32^{\circ} \bmod \mathrm{N} \varnothing$ 


\section{Korrektion}

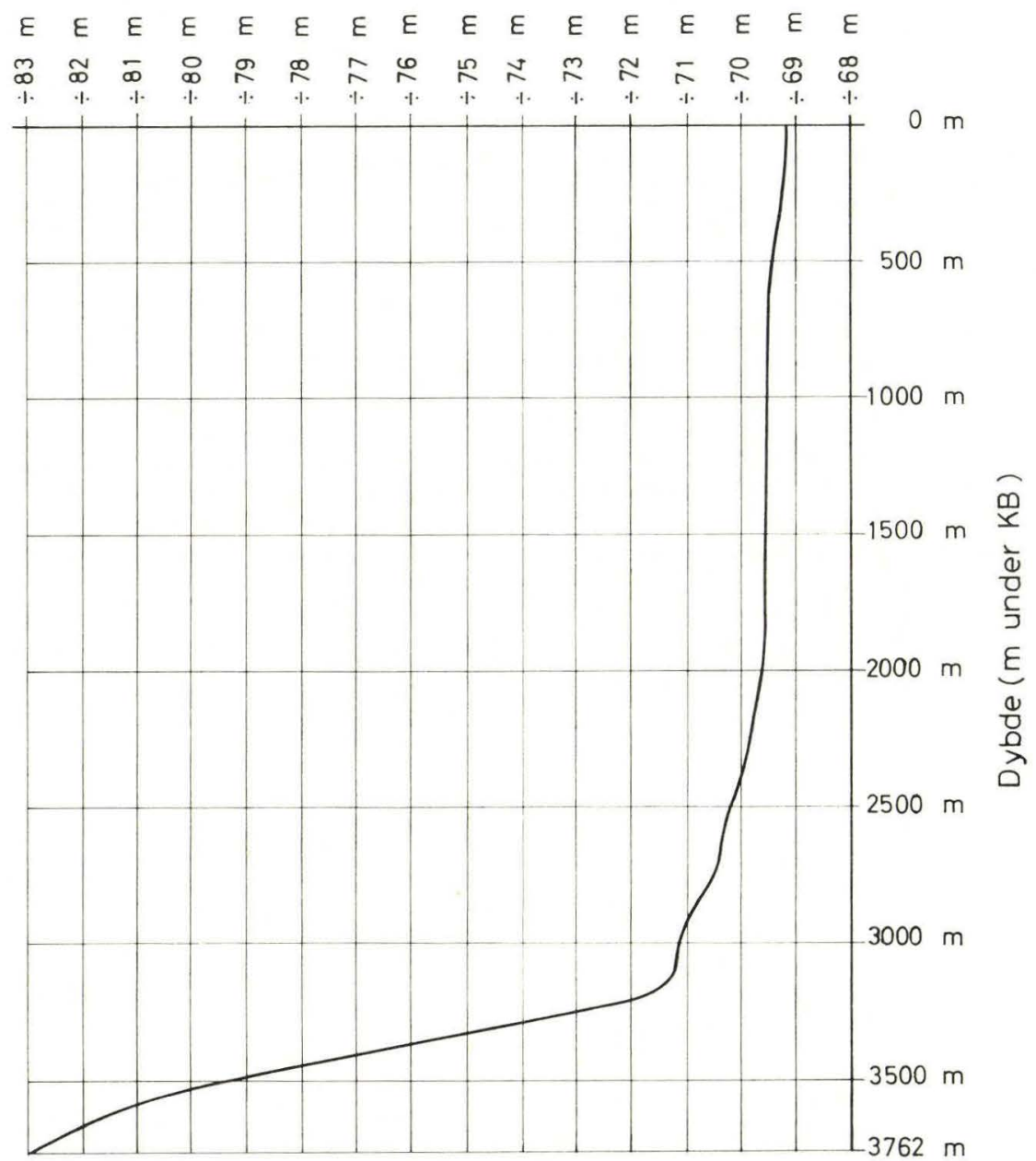

Fig. 11. Korrektionskurve for beregning af koter. For at finde koten for en given boredybde, adder korrektionen og multiplicer med -1 .

Correction curve for determination of level (depth above/below sea level). To find the level at any point of the drilling, add the correction and multiply by -1 .

I tabel 2 gives en oversigt over de punkter, hvor hastigheden af boringens retningsændring (i grader pr. 20 m, se fig. 10) er særlig stor, samt deres fortolkning ud fra lithologien og Schlumbergerprofilerne. 


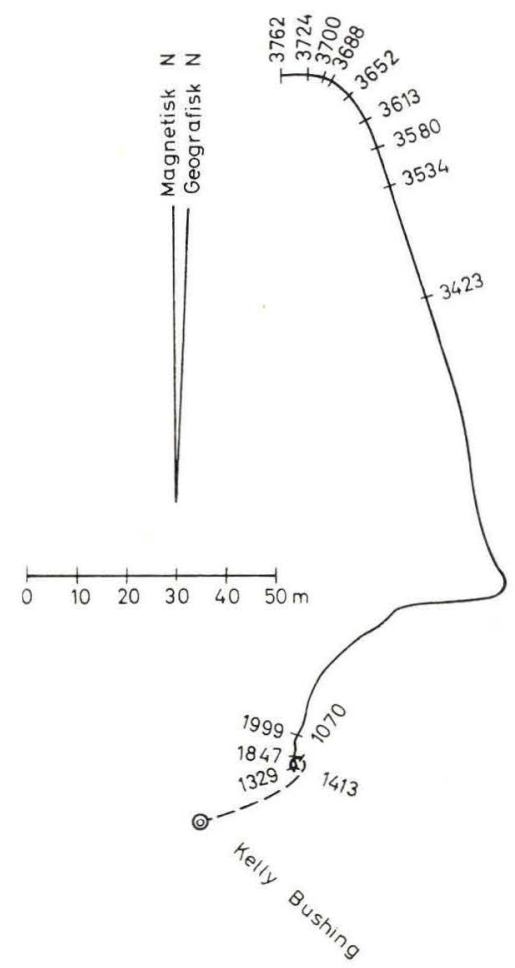

Fig. 12. Boringens horisontalprojektion.

The horizontal projection of the drilling.

Fig. 13. Vertikalprojektion af boringen på et plan i retningen $\mathrm{N}-\mathrm{S}$.

Vertical projection of the boring on a plane running due $N$-due $S$.

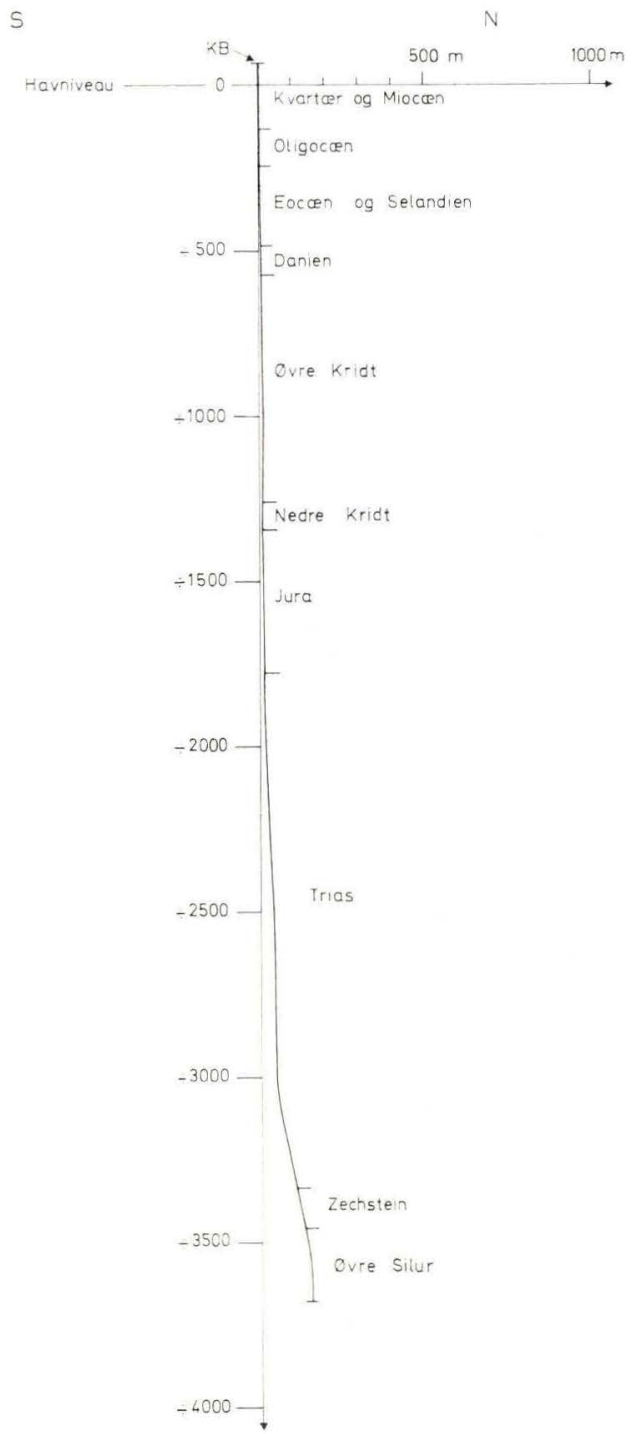

S 
Tabel 1. Tabel over laghældninger. Table of dip and strike.

\begin{tabular}{|c|c|c|c|c|c|c|c|c|c|}
\hline $\begin{array}{c}\text { Dybde (Depth) } \\
\text { (m u. KB) }\end{array}$ & $\begin{array}{l}\text { Antal } \\
\text { (No.) }\end{array}$ & $\begin{array}{l}\text { Hæld } \\
\text { (Devia }\end{array}$ & $\begin{array}{l}\operatorname{lning} \\
\text { ation) }\end{array}$ & $\begin{array}{c}\text { Retning } \\
\text { (Direction) }\end{array}$ & $\begin{array}{l}\text { Standard } \\
\text { afvigelse } \\
\text { (Standard } \\
\text { deviation) }\end{array}$ & $\begin{array}{l}\text { Vurdering af } \\
\text { resultaterne } \\
\text { (Quality of } \\
\text { results) }\end{array}$ & $\begin{array}{l}\text { Bemærkninger } \\
\text { (Remarks) }\end{array}$ & $\begin{array}{l}\text { Strygning } \\
\text { (Strike) }\end{array}$ & $\begin{array}{l}\text { Hældning } \\
\text { (Dip) }\end{array}$ \\
\hline $1259-1280$ & 7 & & $3^{\circ}$ & $40^{\circ}$ & $4.8^{\circ}$ & god (good) & & $\mathrm{N} 60^{\circ} \mathrm{W}-\mathrm{S} 60^{\circ} \varnothing$ & $3^{\circ} \mathrm{NN} \varnothing$ \\
\hline $1280-1285$ & 8 & & $1^{\circ}$ & $10^{\circ}$ & $2.2^{\circ}$ & - & & retØ-retW & $1^{\circ} \mathrm{N}$ \\
\hline $1295-1302$ & 11 & & $4^{\circ}$ & $130^{\circ}$ & $4.3^{\circ}$ & - & & $\mathrm{N} 40^{\circ} \varnothing-\mathrm{S} 40^{\circ} \mathrm{W}$ & $4 \mathrm{~S} \varnothing$ \\
\hline $1302-1315$ & 20 & & $1^{\circ}$ & $160^{\circ}$ & $3.4^{\circ}$ & - & & $\mathrm{N} 60^{\circ} \varnothing-\mathrm{S} 60^{\circ} \mathrm{W}$ & $1^{\circ} \mathrm{SS} \varnothing$ \\
\hline $1315-1329$ & 7 & ca. & $5^{\circ}$ & ca. $50^{\circ}$ & ca. $4.3^{\circ}$ & usikker (poor) & & ca. $\mathrm{N} 40^{\circ} \mathrm{W}-\mathrm{S} 40^{\circ} \varnothing$ & ca. $5^{\circ} \mathrm{N} \varnothing$ \\
\hline $1329-1343$ & 9 & & $2^{\circ}$ & $110^{\circ}$ & $4.6^{\circ}$ & $\operatorname{god}(\operatorname{good})$ & & $\mathrm{N} 20^{\circ} \varnothing-\mathrm{S} 20^{\circ} \mathrm{W}$ & $2^{\circ} \varnothing \mathrm{S} \varnothing$ \\
\hline $1457-1492$ & 13 & ca. & $1^{\circ}$ & ca. $100^{\circ}$ & ca. $7.7^{\circ}$ & - & $\begin{array}{l}\text { krydslejring } \\
\text { (cross-bedding) }\end{array}$ & ca. $\mathrm{N} 10^{\circ} \varnothing-\mathrm{S} 10^{\circ} \mathrm{W}$ & ca. $1^{\circ} \varnothing$ \\
\hline $1847-1854$ & 5 & & $5^{\circ}$ & $250^{\circ}$ & $3.1^{\circ}$ & - & & $\mathrm{N} 20^{\circ} \mathrm{W}-\mathrm{S} 20^{\circ} \varnothing$ & $5^{\circ} \mathrm{WSW}$ \\
\hline $1854-1868$ & 10 & ca. & $4^{\circ}$ & ca. $300^{\circ}$ & ca. $11.0^{\circ}$ & - & $\begin{array}{l}\text { krydslejring } \\
\text { (cross-bedding) }\end{array}$ & ca. $\mathrm{N} 30^{\circ} \varnothing-\mathrm{S} 30^{\circ} \mathrm{W}$ & ca. $4^{\circ} \mathrm{WNW}$ \\
\hline $1868-1885$ & 8 & & $4^{\circ}$ & $210^{\circ}$ & $4.0^{\circ}$ & - & & $\mathrm{N} 60^{\circ} \mathrm{W}-\mathrm{S} 60^{\circ} \varnothing$ & $4^{\circ} \mathrm{SSW}$ \\
\hline $1885-1903$ & 7 & ca. & $2^{\circ}$ & ca. $200^{\circ}$ & ca. $6.9^{\circ}$ & - & $\begin{array}{l}\text { krydslejring? } \\
\text { (cross-bedding?) }\end{array}$ & ca. $\mathrm{N} 70^{\circ} \mathrm{W}-\mathrm{S} 70^{\circ} \varnothing$ & ca. $2^{\circ} \mathrm{SSW}$ \\
\hline 1903-1932 & 13 & & $5^{\circ}$ & $230^{\circ}$ & $4.6^{\circ}$ & - & & $\mathrm{N} 50^{\circ} \mathrm{W}-\mathrm{S} 50^{\circ} \varnothing$ & $5^{\circ} \mathrm{SW}$ \\
\hline $1932-1939$ & 9 & & $2^{\circ}$ & $190^{\circ}$ & $5.3^{\circ}$ & - & & $\mathrm{N} 80^{\circ} \mathrm{W}-\mathrm{S} 80^{\circ} \varnothing$ & $2^{\circ} \mathrm{S}$ \\
\hline $1939-1952$ & 11 & & $4^{\circ}$ & $280^{\circ}$ & $4.5^{\circ}$ & - & & ret $\mathrm{N}$-ret $\mathrm{S}$ & $4^{\circ} \mathrm{W}$ \\
\hline $1952-1965$ & 5 & ca. & $5^{\circ}$ & ca. $240^{\circ}$ & ca. $4.6^{\circ}$ & usikker (poor) & & ca. $\mathrm{N} 30^{\circ} \mathrm{W}-\mathrm{S} 30^{\circ} \varnothing$ & ca. $5^{\circ} \mathrm{WSW}$ \\
\hline $1965-1981$ & 19 & & $5^{\circ}$ & $210^{\circ}$ & $4.3^{\circ}$ & god (good) & & $\mathrm{N} 60^{\circ} \mathrm{W}-\mathrm{S} 60^{\circ} \varnothing$ & $5^{\circ} \mathrm{SSW}$ \\
\hline $1981-1993$ & 14 & & $5^{\circ}$ & $230^{\circ}$ & $3.7^{\circ}$ & - & & $\mathrm{N} 50^{\circ} \mathrm{W}-\mathrm{S} 50^{\circ} \varnothing$ & $5^{\circ} \mathrm{SW}$ \\
\hline 1993-2000 & 6 & ca. & $3^{\circ}$ & ca. $240^{\circ}$ & ca. $10.6^{\circ}$ & usikker (poor) & $\begin{array}{l}\text { krydslejring(?) } \\
\text { (cross-bedding(?)) }\end{array}$ & ca. $\mathrm{N} 30^{\circ} \mathrm{W}-\mathrm{S} 30^{\circ} \varnothing$ & ca. $3^{\circ} \mathrm{WSW}$ \\
\hline 2000-2010 & 15 & & $7^{\circ}$ & $210^{\circ}$ & $4.6^{\circ}$ & $\operatorname{god}($ good) & & $\mathrm{N} 60^{\circ} \mathrm{W}-\mathrm{S} 60^{\circ} \varnothing$ & $7^{\circ} \mathrm{SSW}$ \\
\hline 2010-2025 & 18 & & $7^{\circ}$ & $230^{\circ}$ & $5.7^{\circ}$ & - & & $\mathrm{N} 40^{\circ} \mathrm{W}-\mathrm{S} 40^{\circ} \varnothing$ & $7^{\circ} \mathrm{SW}$ \\
\hline $2025-2038$ & 18 & & $4^{\circ}$ & $220^{\circ}$ & $4.2^{\circ}$ & - & & $\mathrm{N} 60^{\circ} \mathrm{W}-\mathrm{S} 60^{\circ} \varnothing$ & $4^{\circ} \mathrm{SSW}$ \\
\hline 2038-2060 & 27 & & $6^{\circ}$ & $240^{\circ}$ & $4.8^{\circ}$ & - & & $\mathrm{N} 30^{\circ} \mathrm{W}-\mathrm{S} 30^{\circ} \varnothing$ & $6^{\circ} \mathrm{WSW}$ \\
\hline $2359-2411$ & 14 & & $8^{\circ}$ & $260^{\circ}$ & $5.8^{\circ}$ & - & & $\mathrm{N} 20^{\circ} \mathrm{W}-\mathrm{S} 20^{\circ} \varnothing$ & $8^{\circ} \mathrm{WSW}$ \\
\hline
\end{tabular}




\begin{tabular}{|c|c|c|c|c|c|c|c|c|}
\hline $\begin{array}{l}\text { Dybde (Depth) } \\
(\mathrm{m} \text { u. KB) }\end{array}$ & $\begin{array}{l}\text { Antal } \\
\text { (No.) }\end{array}$ & $\begin{array}{l}\text { Hældning } \\
\text { (Deviation) }\end{array}$ & $\begin{array}{c}\text { Retning } \\
\text { (Direction) }\end{array}$ & $\begin{array}{l}\text { Standard } \\
\text { afvigelse } \\
\text { (Standard } \\
\text { deviation) }\end{array}$ & $\begin{array}{l}\text { Vurdering af } \\
\text { resultaterne } \\
\text { (Quality of } \\
\text { results) }\end{array}$ & $\begin{array}{l}\text { Bemærkninger } \\
\text { (Remarks) }\end{array}$ & $\begin{array}{l}\text { Strygning } \\
\text { (Strike) }\end{array}$ & $\begin{array}{l}\text { Hældning } \\
\text { (Dip) }\end{array}$ \\
\hline $2832-2863$ & 14 & $6^{\circ}$ & $290^{\circ}$ & $7.8^{\circ}$ & - & $\begin{array}{c}\text { krydslejring(?) } \\
\text { (cross-bedding(?)) }\end{array}$ & $\mathrm{N} 20^{\circ} \varnothing-\mathrm{S} 20^{\circ} \mathrm{W}$ & $6^{\circ} \mathrm{WNW}$ \\
\hline $2863-2886$ & 15 & $6^{\circ}$ & $310^{\circ}$ & $6.9^{\circ}$ & - & & $\mathrm{N} 30^{\circ} \varnothing-\mathrm{S} 30^{\circ} \mathrm{W}$ & $6^{\circ} \mathrm{WNW}$ \\
\hline $2900-2939$ & 17 & $2^{\circ}$ & $350^{\circ}$ & $10.3^{\circ}$ & - & $\begin{array}{l}\text { krydslejring(?) } \\
\text { (cross-bedding(?)) }\end{array}$ & $\mathrm{N} 80^{\circ} \varnothing-\mathrm{S} 80^{\circ} \mathrm{W}$ & $2^{\circ} \mathrm{N}$ \\
\hline 2939-2976 & 14 & $2^{\circ}$ & $320^{\circ}$ & $6.3^{\circ}$ & - & & $\mathrm{N} 40^{\circ} \varnothing-\mathrm{S} 40^{\circ} \mathrm{W}$ & $2^{\circ} \mathrm{NW}$ \\
\hline 2999-3051 & 17 & $11^{\circ}$ & $190^{\circ}$ & $6.2^{\circ}$ & - & & ret $\varnothing$-ret W & $11^{\circ} \mathrm{S}$ \\
\hline $3071-3084$ & 4 & ca. $27^{\circ}$ & ca. $180^{\circ}$ & ca. $12.0^{\circ}$ & - & $\begin{array}{l}\text { krydslejring(?) } \\
\text { (cross-bedding(?)) }\end{array}$ & ca. ret Ø-ret W & ca. $27^{\circ} \mathrm{S}$ \\
\hline $3084-3180$ & 13 & $34^{\circ}$ & $170^{\circ}$ & $6.5^{\circ}$ & - & & $\mathrm{N} 80^{\circ} \varnothing-\mathrm{S} 80^{\circ} \mathrm{W}$ & $34^{\circ} \mathrm{S}$ \\
\hline $3180-3225$ & 13 & $40^{\circ}$ & $190^{\circ}$ & $8.2^{\circ}$ & - & $\begin{array}{l}\text { krydslejring(?) } \\
\text { (cross-bedding(?)) }\end{array}$ & ret $\varnothing$-ret W & $40^{\circ} \mathrm{S}$ \\
\hline $3225-3259$ & 6 & $?$ & $?$ & $?$ & & & & \\
\hline $3315-3338$ & 7 & ca. $13^{\circ}$ & ca. $10^{\circ}$ & ca. $5.9^{\circ}$ & usikker (poor) & $\begin{array}{l}\text { lagdeling?? } \\
\text { (bedding??) }\end{array}$ & ca. $\mathrm{N} 80^{\circ} \mathrm{W}-\mathrm{S} 80^{\circ} \varnothing$ & ca. $13^{\circ} \mathrm{N}$ \\
\hline $3537-3541$ & 5 & $34^{\circ}$ & $70^{\circ}$ & $5.1^{\circ}$ & god (good) & & $\mathrm{N} 30^{\circ} \mathrm{W}-\mathrm{S} 30^{\circ} \varnothing$ & $34^{\circ} \varnothing \mathrm{N} \varnothing$ \\
\hline $3551-3559$ & 5 & $31^{\circ}$ & $50^{\circ}$ & $4.5^{\circ}$ & - & & $\mathrm{N} 40^{\circ} \mathrm{W}-\mathrm{S} 40^{\circ} \varnothing$ & $31^{\circ} \mathrm{N} \varnothing$ \\
\hline $3559-3578$ & 2 & ca. $31^{\circ}$ & ca. $70^{\circ}$ & ca. $10.0^{\circ}$ & usikker (poor) & $\begin{array}{l}\text { krydslejring? } \\
\text { (cross-bedding?) }\end{array}$ & ca. $\mathrm{N} 20^{\circ} \mathrm{W}-\mathrm{S} 20^{\circ} \varnothing$ & ca. $31^{\circ} \varnothing \mathrm{N} \varnothing$ \\
\hline $3578-3611$ & 7 & ca. $30^{\circ}$ & ca. $270^{\circ}$ & ca. $11.8^{\circ}$ & $\operatorname{god}(\operatorname{good})$ & $\begin{array}{l}\text { forkløftning(?) } \\
\text { (jointing(?)) }\end{array}$ & ca. $\mathrm{N} 10^{\circ} \mathrm{W}-\mathrm{S} 10^{\circ} \varnothing$ & ca. $30^{\circ} \mathrm{W}$ \\
\hline $3611-3641$ & 6 & ca. $35^{\circ}$ & ca. $40^{\circ}$ & ca. $9.0^{\circ}$ & - & $\begin{array}{l}\text { krydslejring? } \\
\text { (cross-bedding?) }\end{array}$ & ca. $\mathrm{N} 60^{\circ} \mathrm{W}-\mathrm{S} 60^{\circ} \varnothing$ & ca. $35^{\circ} \mathrm{NN} \varnothing$ \\
\hline $3641-3688$ & 2 & ca. $31^{\circ}$ & ca. $50^{\circ}$ & ca. $12.7^{\circ}$ & usikker (poor) & $\begin{array}{l}\text { lavabænke? } \\
\text { (lava beds?) }\end{array}$ & ca. $\mathrm{N} 50^{\circ} \mathrm{W}-\mathrm{S} 50^{\circ} \varnothing$ & ca. $31^{\circ} \mathrm{N} \varnothing$ \\
\hline $3726-3759$ & 2 & ca. $11^{\circ}$ & ca. $80^{\circ}$ & ca. $2.4^{\circ}$ & usikker (poor) & $\begin{array}{l}\text { lagdeling?? } \\
\text { (bedding??) }\end{array}$ & ca. $\mathrm{N} 10^{\circ} \mathrm{W}-\mathrm{S} 10^{\circ} \varnothing$ & ca. $11^{\circ} \emptyset$ \\
\hline
\end{tabular}


Tabel 2. Bestemmelse af dybder for laghældningsændringer.

Determination of depths of change in dip.

\begin{tabular}{|c|c|c|}
\hline \multicolumn{2}{|c|}{$\begin{array}{l}\text { Dybde af laghældningsændring } \\
\text { (m under KB) } \\
\text { Depth of change in dip } \\
\text { ( } \mathrm{m} \text { below KB) }\end{array}$} & \multirow[b]{2}{*}{$\begin{array}{l}\text { Formodet ændringsårsag } \\
\text { Supposed cause of change }\end{array}$} \\
\hline $\begin{array}{l}\text { Aflæst fra } \\
\text { fig. } 10 \\
\text { Read from } \\
\text { fig. } 10\end{array}$ & $\begin{array}{l}\text { Andring iflg. } \\
\text { Schlumberger } \\
\text { målinger eller } \\
\text { lithologi } \\
\text { Change accord. } \\
\text { to Schlumberger } \\
\text { measurements or } \\
\text { lithology }\end{array}$ & \\
\hline 1350 & 1355 & top af hauterivien \\
\hline 1400 & 1413 & top af jura \\
\hline 2110 & 2074 & top af ? »Rote Wand « \\
\hline 2330 & 2323 & $\begin{array}{l}\text { lithologisk ændring; svag diskordans? } \\
\text { (lithologic change; small unconformity?) }\end{array}$ \\
\hline 2420 & 2429 & $\begin{array}{l}\text { top af stensalt-førende afsnit } \\
\text { (top of rock salt section) }\end{array}$ \\
\hline 2630 & 2618 & $\begin{array}{l}\text { bund af stensalt-førende afsnit } \\
\text { (base of rock salt section) }\end{array}$ \\
\hline 2700 & 2692 (?) & $\begin{array}{l}\text { svag lithologisk ændring } \\
\text { (slight lithologic change) }\end{array}$ \\
\hline 3060 & 3045 & $\begin{array}{l}\text { lithologisk ændring } \\
\text { (lithologic change) }\end{array}$ \\
\hline 3130 & ca. 3118 & $\begin{array}{l}\text { lithologisk ændring } \\
\text { (lithologic change) }\end{array}$ \\
\hline 3420 & 3423 & top af zechstein \\
\hline 3540 & 3534 & $\begin{array}{l}\text { top af } ø v r e \text { silur } \\
\text { (top of Upper Silurian) }\end{array}$ \\
\hline 3630 & 3613 & $\begin{array}{l}\text { bund af øverste basalt } \\
\text { (base of uppermost basalt section) }\end{array}$ \\
\hline 3700 & 3700 & $\begin{array}{l}\text { lithologisk ændring; vinkeldiskordans (?) } \\
\text { (lithologic change; angular unconformity (?)) }\end{array}$ \\
\hline
\end{tabular}

ENGLISH SUMMARY

\section{DETERMINATION OF DEVIATIONS, DIPS AND TEMPERATURE GRADIENT OF NØVLING NO. 1}

\section{DEVIATION OF THE BORING}

Continuous dipmeter logs are available for the interval 1070-3759 m (below KB); above this interval only drift indicator measurements have been made.

Fig. 10 shows graphically the direction of the drilling at any point in the interval $1070-3759 \mathrm{~m}$ (below KB).

For the interval not measured with the continuous dipmeter, the deviation and azimuth 
Tabel 3. Temperaturmålinger.

Temperature measurements.

\begin{tabular}{|c|c|c|c|c|c|c|}
\hline $\begin{array}{l}\text { Dato } \\
(1966)\end{array}$ & K1. & $\begin{array}{c}\text { Type af } \\
\text { Schlum- } \\
\text { bergermåling }\end{array}$ & $\begin{array}{c}\text { Dybde } \\
(\mathrm{m} \mathrm{u.KB})\end{array}$ & $\begin{array}{c}\text { Tempe- } \\
\text { ratur }\end{array}$ & $\begin{array}{c}\text { Dia- } \\
\text { meter* }\end{array}$ & Bjergart \\
\hline 29. okt. & $01: 00$ & sonic & 3533 & $83^{\circ} \mathrm{C}$ & $13^{\prime \prime}$ & $\begin{array}{l}\text { dolomitisk } \\
\text { lerskifer }\end{array}$ \\
\hline 29. okt. & $13: 00$ & $\begin{array}{l}\text { gammaray- } \\
\text { neutron }\end{array}$ & 3534 & $88^{\circ} \mathrm{C}$ & $13^{\prime \prime}$ & $\begin{array}{l}\text { dolomitisk } \\
\text { lerskifer }\end{array}$ \\
\hline 30. okt. & $01: 00$ & sonic & 3532 & $91^{\circ} \mathrm{C}$ & $13^{\prime \prime}$ & $\begin{array}{l}\text { dolomitisk } \\
\text { lerskifer }\end{array}$ \\
\hline 30. okt. & $06: 00$ & $\begin{array}{l}\text { comp.form. } \\
\text { density }\end{array}$ & 3533 & $93^{\circ} \mathrm{C}$ & $13^{\prime \prime}$ & $\begin{array}{l}\text { dolomitisk } \\
\text { lerskifer }\end{array}$ \\
\hline 15. nov. & & $\begin{array}{l}\text { contin. } \\
\text { dipmeter }\end{array}$ & 3759 & $95^{\circ} \mathrm{C}$ & $8^{\prime \prime}$ & lerskifer \\
\hline
\end{tabular}

* borehullets diameter med mudderkage.

have been estimated for points at $50 \mathrm{~m}$ intervals by extrapolation and comparison with the drift indicator results.

The boring has been subdivided into a number of short $(50 \mathrm{~m}, 20 \mathrm{~m}$ or less) intervals, for each of which the vertical correction and the horizontal component have been calculated (by means of the sinus versus and the sinus functions, respectively). The cumulative vertical correction, combined with the elevation of the KB above sea level, is shown graphically in fig. 11. Fig. 12 shows the horizontal projection of the boring, and fig. 13 shows a vertical projection on a plane running due $\mathrm{N}$ - due $\mathrm{S}$.

\section{CALCULATION OF DIPS}

In Nøvling No. 1, dips have been determined by the continuous dipmeter for 437 points distributed in the intervals 1070-1159 m, 1250-1551 m, 1691-1692 m, 1837-2101 m, 2186$2222 \mathrm{~m}, 2250-2425 \mathrm{~m}, 2485-2486 \mathrm{~m}, 2635-2741 \mathrm{~m}, 2818-3266 \mathrm{~m}, 3291-3292 \mathrm{~m}, 3300-$ $3351 \mathrm{~m}, 3390-3431 \mathrm{~m}$, and $3454-3759 \mathrm{~m}$.

Table 1 shows the results of calculations of average values of the dip for a number of sections with uniform lithology. The modal average and its standard deviation are given for each section, the directions and strikes being rounded off to the nearest $10^{\circ}$ and the deviations and dips to the nearest degree. Directions refer to magnetic north, strikes to geographic north.

The results of table 1 can be summarized as follows:

$1259-1492 \mathrm{~m}$ about $2^{\circ}$ toward $\mathrm{E}$, only slightly varying

$1847-2060 \mathrm{~m}$ about $4^{\circ}$ toward SW, only slightly varying

$2359-2411 \mathrm{~m} \quad 8^{\circ}$ toward WSW, only slightly varying

2832-2976 m $\quad 4^{\circ}$ toward WNW, only slightly varying

2999-3259 $\mathrm{m}$ gradually changing downward from $11^{\circ}$ toward $\mathrm{S}$ to $40^{\circ}$ toward $\mathrm{S}$

$3315-3338 \mathrm{~m}$ about $13^{\circ}$ toward $\mathrm{N}$ (this value probably does not represent bedding)

$3537-3688 \mathrm{~m}$ gradually changing downward from $35^{\circ}$ toward ENE to $32^{\circ}$ toward NE 
A comparison of the direction of the boring at any point with the dip of the bedding at that point reveals the well-known tendency of the boring to take a direction perpendicular to the bedding; this direction usually is only somewhat approximated, since the direction of the bedding may change before the adjustment has become complete.

In fig. 10 the linear distance scaled graphically between two consecutive $20 \mathrm{~m}$ marks shows the rate of change of direction of the boring in units of degrees per $20 \mathrm{~m}$. This rate of change is in certain places particularly large. The depth at which such an increase in the rate of change of direction begins may in most cases be supposed to correspond to a major or at least more significant change in the direction of dip. Table 2 lists these depths and gives their probable or possible interpretation on the basis of lithology and Schlumberger logs.

\section{DETERMINATION OF THE TEMPERATURE GRADIENT}

In connection with the Schlumberger measurements the following temperature measurements have been made (see table 3 p. 61).

These measurements fit well together, and taking the yearly mean temperature at Nøvling No. 1 to be $+7^{\circ} \mathrm{C}$, the average temperature gradient is found to be $41 \mathrm{~m} /{ }^{\circ} \mathrm{C}$ between the Earth's surface and $3759 \mathrm{~m}$ depth. 


\title{
OLIGOCÆN OG MIOCÆN I NØVLING NR. 1 $(0-312 \mathrm{M})$
}

\author{
BIOSTRATIGRAFISK UNDERSøGELSE PA GRUNDLAG \\ AF FORAMINIFERER
}

af

Finn Nyhuus Kristoffersen

Den foreliggende undersøgelse af intervallet $60^{\prime}-1050^{\prime}(18-312 \mathrm{~m})$ er baseret på foraminiferer. Ialt 39 skylleprøver udtaget med intervaller på 10, 15, $20 \mathrm{og}$ 30 fod er undersøgt, idet 30 fods intervaller er det almindeligste.

\section{LITHOLOGI}

Den lithologiske oversigt er sammenstillet på grundlag af beskrivelser foretaget af Olaf Michelsen og Finn Nyhuus Kristoffersen. Den lithologiske beskrivelse er forsøgt korrigeret i forhold til Schlumbergermålinger, men med ringe resultat, idet skylleprøverne er af en dårlig kvalitet bl.a. som følge af den store borehastighed i denne den øverste del af boringen. Endvidere vil afsnittets ukonsoliderede og oftest sandede bjergarter opslæmmes i boremudderet, således at egentlige cuttings sjældent lader sig identificere. Kun afsnittets nedre grænse (312 m) har kunnet korrigeres i forhold til Schlumbergermålinger, og denne dybde er angivet $\mathrm{i}$ meter under kelly bushing. Dybder for udtagne skylleprøver er angivet i engelske fod under kelly bushing, medens tilsvarende dybder omregnet til meter er anført i parentes.

$60^{\prime}-90^{\prime}$ Sand, mellemk.-groft. Brunkul optræder i den øvre del af intervallet.

$90^{\prime}-225^{\prime}$ Ler, mørkebrunt, glimmerholdigt, kalkfrit.

$225^{\prime}-240^{\prime}$ Brunkul. Mellemk.-groft sand optræder i små mængder.

$240^{\prime}-360^{\prime}$ Sand, mellemk.-groft. Brunkul forekommer formentlig underordnet. Især i den nedre del af afsnittet optræder en del glimmerholdigt ler.

$360^{\prime}-450^{\prime}$ Ler, mørkebrunt, glimmerholdigt, kalkfrit. Sand tiltager nedefter. $450^{\prime}-660^{\prime}$ Sand, mellemk.-groft, afvekslende med mørkebrunt, glimmerholdigt ler. Fra 470' optræder en finkornet, grå, stærkt kalkholdig sandstenskonkretion, som ofte indeholder mollusk-fragmenter og polerede kvartskorn i grusfraktion.

$660^{\prime}-1050^{\prime}$ Ler, mørkebrunt, glimmerholdigt, svagt kalkholdigt. Fra 750' indeholder prøverne en stigende mængde glaukonit. 
NØVLING NR.1

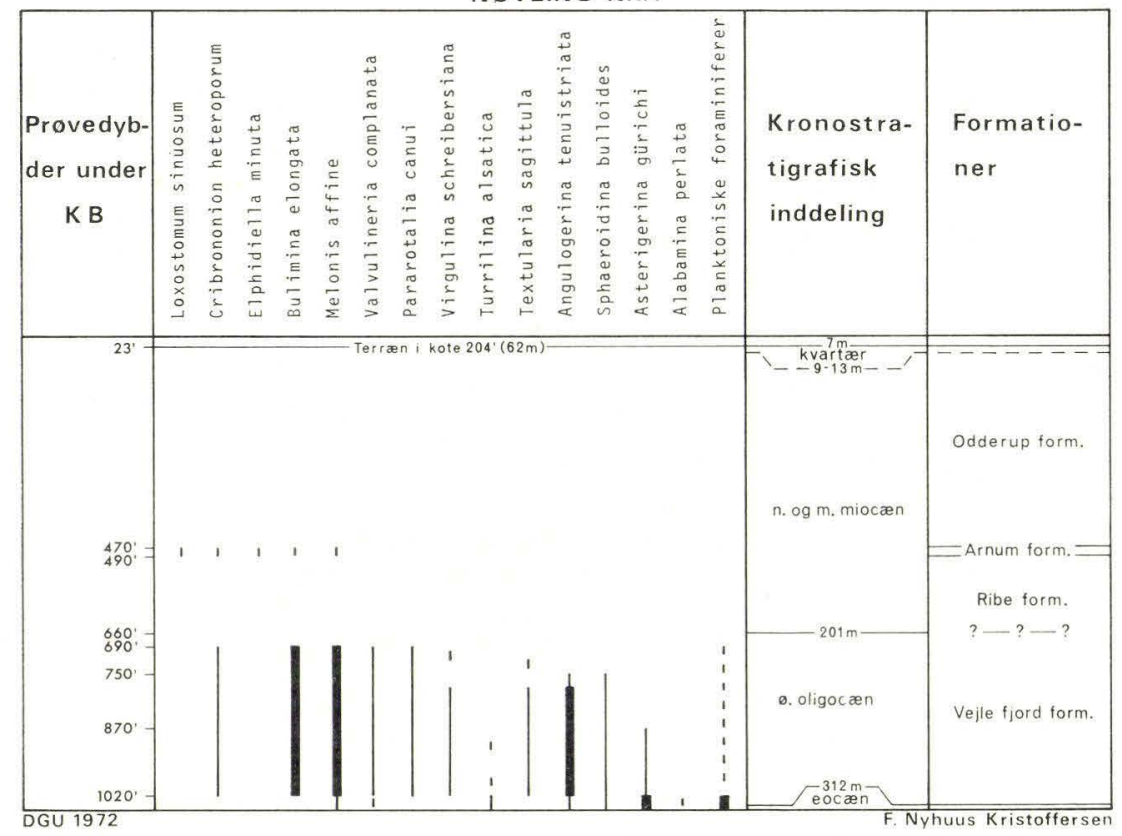

Fig. 14

Prøven fra $1020^{\prime}-1050^{\prime}$ er præget af den karakteristiske lyse eocæne mergel, som vil blive behandlet af ARNE DINESEN (se side 71). Udover talrige eocæne foraminiferer indeholder prøven imidlertid en oligocæn foraminiferfauna, som afviger en del i forhold til den, der findes i de overliggende prøver. Grænsen mellem den lyse mergel og det mørkebrune, glimmerholdige ler svarende til grænsen mellem lag af henholdsvis eocæn og oligocæn alder, må derfor søges indenfor prøveintervallet $1020^{\prime}-1050^{\prime}$. Som allerede omtalt giver denne grænse sig tydeligt til kende på Schlumberger logs ved $312 \mathrm{~m}$.

\section{BIOSTRATIGRAFI}

Som det allerede vil fremgå af den lithologiske oversigt, falder afsnittet naturligt i to enheder. Øverst fra $60^{\prime}-660^{\prime}$ en serie hovedsagelig bestående af sandede aflejringer med indslag af ler og brunkul. Herunder fra $660^{\prime}-1050^{\prime}$ en overvejende glaukonitholdig ler serie.

Afsnittet $60^{\prime}-660^{\prime}(18-201 \mathrm{~m})$

Foraminiferer optræder kun i prøven $470^{\prime}-490^{\prime}$. Der er tale om en både individog artsfattig fauna, og tilmed er skallerne i en dårlig bevaringstilstand. Nogle få karakteristiske foraminiferer skal nævnes: 


\section{Loxostomum sinuosum CUSHMAN 1936 \\ Cribrononion heteroporum (EGGER 1857) \\ Elphidiella minuta (REuss 1865)}

Loxostomum sinuosum kendes fra en række boringer i Jylland i lag tilhørende Klintinghoved formationen, i hvilken den dog er sjælden og morfologisk ukarakteristisk, og i den nedre del af Arnum formationen, medens Elphidiella minuta kun er fundet i Arnum formationen (KRISTOFFERSEN 1972). En placering i den nedre del af Arnum formationen må derfor være naturlig og støttes da også af faunabilledet iøvrigt. Arnum formationen er på basis af mollusker blevet korreleret med den tyske Hemmoorer Stufe (SORGENFrei 1958).

Udover de dårligt bevarede foraminiferer i prøven $470^{\prime}-490^{\prime}$ er der iagttaget vidnesbyrd om marine lag i intervallet $450^{\prime}-690^{\prime}$, idet der optræder marine mollusker i en del af prøverne. Da prøverne imidlertid er af en dårlig kvalitet, kan tilstedeværelsen af marine mollusker i de fleste af prøverne ikke tages som udtryk for, at hele det nedre afsnit er af marin oprindelse. Tværtimod må det formodes, at hovedparten af fossilerne repræsenterer nedfald hidrørende fra nogle få marine indslag i en iøvrigt non-marin serie. L. BANKE RASMUSSEN har undersøgt de fundne mollusker og knytter følgende bemærkninger hertil:

»Fra intervallet 490'-690' i Nøvling nr. 1 foreligger en del rester af marine mollusker, som delvis har kunnet bestemmes. I prøven 490'-510' fandtes bl. a. Nucula sp., Leda westendorpii (Nyst \& Westendorp), Hinia schlotheimi (Beyrich) og Aquilofusus cf. grippi (KaUtSky). Prøven 540'-570' indeholder overvejende pelecypod-fragmenter, især af Nucula cf. nucleus (LINNÉ), samt enkelte skaller af Leda pygmaea (MÜNSTER) og fragmenter af Spisula subtruncata (DA CosTA) var. Prøven 570'-600' er præget af talrige fragmenter af en Nucula (formodentlig $N$. nucleus). Det samme gælder prøverne $600^{\prime}-630^{\prime}$ og 630'-660'. I prøven $600^{\prime}-630^{\prime}$ fandtes tillige et fragment af en Ringicula. Et større artsindhold er tilstede i prøven 660'-690', hvor der bl.a. forekommer Nucula sp., Leda westendorpii, Yoldia cf. glaberrima (Münster), Laevicardium sp., Spisula subtruncata, Dentalium sp., Natica sp., Hinia schlotheimi, Admete fusiformis (CANTrAIne), Turricula steinvorthi (v. Koenen), Acteon sp. og Ringicula buccinea (BRocCHI). Foruden disse mollusker findes i flere prøver otolither og hajtænder.

Samtlige nævnte arter er kendt fra Arnum formationen (se Sorgenfrei 1958), og de fundne skalrester må anses for rester af molluskselskaber fra marine lag i denne formation. En stor dominans af Nucula synes imidlertid ikke at karakterisere noget tidligere publiceret artsselskab fra Danmarks miocæn. På den anden side er der næppe tvivl om, at skalresterne i prøverne fra Nøvling hidrører fra Arnum lag og således er miocæne. Det er derimod usikkert, om mere end én skalførende horisont er repræsenteret«.

Hele afsnittet fra $60^{\prime}-660^{\prime}$ må opfattes som en i hovedsagen non-marin lagserie med enkelte marine indslag. De marine indslag kan som allerede nævnt henføres til den nedre del af Arnum formationen på grundlag af deres indhold af foraminiferer og mollusker, medens de non-marine lag må henføres til Ribe formationen og Odderup formationen (fig. 14).

Grænsen mellem de allerede omtalte lag af miocæn alder og kvartære lag må søges i den allerøverste del af boringen fra $0-60^{\prime}$, hvorfra ingen prøver er 
udtaget. D.G.U.'s borearkiv indeholder ingen oplysninger om boringer i umiddelbar nærhed af Nøvling boringen, men $i$ en afstand af 4-6 kilometer herfra findes en del boringer, i hvilke grænsen tertiær-kvartær er beliggende 2-6 meter under terræn.

\section{Afsnittet $660^{\prime}-1050^{\prime}(201-312 \mathrm{~m})$}

Foraminiferer er bortset fra den øverste prøve $660^{\prime}-690^{\prime}$ tilstede i samtlige prøver i intervallet. I den øvre del fra $690^{\prime}-780^{\prime}$ er der tale om en både individog artsfattig fauna udelukkende bestående af former, som også optræder i den nedre del. Følgende foraminiferer skal nævnes:

Pararotalia canui (Cushman 1928)

Valvulineria complanata (D’ORBIGNY 1846)

Melonis affine (Reuss 1851)

Bulimina elongata D'ORBIGNY 1846

Cribrononion heteroporum (EGGER 1857)

Afsnittets nedre del fra $780^{\prime}-1050^{\prime}$ er ret individ- og artsrig. Fra $780^{\prime}-1020^{\prime}$ indeholder prøverne en meget ensartet fauna. Udover de allerede nævnte karakteristiske former, som også optrådte i afsnittets øvre del, skal nævnes:

Angulogerina tenuistriata (REUSS 1870)

Sphaeroidina bulloides D'ORBIGNY 1826

Virgulina schreibersiana CzJzEK 1847

Textularia sagittula Defrance 1824

Asterigerina gürichi (FRANKE 1912)

Angulogerina tenuistriata, Melonis affine og Bulimina elongata dominerer intervallet, medens Asterigerina gürichi, der først optræder fra 870', kun indgår med forholdsvis små værdier.

Den nederste prøve i afsnittet repræsenterende intervallet $1020^{\prime}-1050^{\prime}$ indeholder en række helt nye foraminiferer, hvoraf hovedparten stammer fra den lyse eocæne mergel, som vil blive behandlet af ARNE DINESEN (se side 71).

To former, som kunne antyde tilstedeværelsen af lag af mellem oligocæn alder, skal nævnes:

\section{Alabamina perlata (ANDREAE 1884)}

Turrilina alsatica (ANDREAE 1884)

Ifølge en mundtlig meddelelse fra ARNE DinESEN kan Alabamina perlata imidlertid optræde allerede i den øvre eocæne Søvind mergel. Da de foreliggende Turrilina former heller ikke med tilstrækkelig sikkerhed kan erkendes som mellem oligocæne, fordi en tilsvarende variationsbredde ikke er ualmindelig i øvre eocæne lag, må det anses for yderst tvivlsomt, om mellem oligocæne lag er tilstede i boringen. En mellem oligocæn foraminiferfauna har da heller ikke kunnet udskilles. 
Det er betydningsfuldt, at Asterigerina gürichi i denne prøve optræder med en hyppighed svarende til omkring $25 \%$ af de frasorterede foraminiferer. Prøveintervallet $1020^{\prime}-1050^{\prime}$ må derfor omfatte lag af såvel eocæn som øvre oligocæn alder, idet det må anses for overvejende sandsynligt, at den foreliggende Asterigerina fauna repræsenterer basis af øvre oligocæn, hvilket er i overensstemmelse med opfattelsen af den oligocæne Asterigerina horisont i Niederrhein området i Tyskland (Ellermann 1960 og Indans 1965). Det herover følgende afsnit fra 690'-1020' viser da også god faunistisk lighed med øvre oligocæne faunaer fra Brejning (DINESEN 1959) og Niederrhein området, blandt andet ved tilstedeværelsen af de karakteristiske former Virgulina schreibersiana og Pararotalia canui.

Endelig skal nævnes, at der i prøven $690^{\prime}-720^{\prime}$ optræder kvartære foraminiferer. Deres tilstedeværelse i prøven må forklares ved forurening under borearbejdet.

\section{KONKLUSION}

Som det fremgår af det foregående, kan lagserien opdeles i en nedre marin del fra $660^{\prime}-1050^{\prime}$ (201-312 m) indeholdende en oligocæn foraminiferfauna og en øvre overvejende non-marin del fra 60'-660' (18-201 m) med enkelte marine indslag indeholdende miocæne foraminiferer og mollusker.

Det oligocæne afsnit omfatter formentlig kun lag af øvre oligocæn alder, idet tilstedeværelsen af mellem oligocæne lag er meget tvivlsom.

Herover følger miocæne lag fra $60^{\prime}-660^{\prime}$ indeholdende enkelte marine lag i den nedre del fra 450'. Disse lag kan på grundlag af foraminiferer og mollusker henføres til den nedre del af Arnum formationen. Den ikke marine del af afsnittet er derfor henført til Ribe formationen og Odderup formationen.

Marine lag tilhørende den nedre miocæne Klintinghoved formation er ikke registreret. Den yngre del af miocænet svarende til Hodde og Gram formationerne mangler fuldstændig.

Da skylleprøver først er udtaget fra en dybde af 60', har det ikke været muligt at fastlægge grænsen imellem tertiær og kvartær på basis af udtagne prøver. Da denne grænse i en række boringer i det pågældende område er fundet i en dybde på mellem 2 og 6 meter, må det formodes, at noget tilsvarende gør sig gældende i den aktuelle boring.

ENGLISH SUMMARY

OLIGOCENE AND MIOCENE IN NØVLING NO. 1

A biostratigraphical study on the basis of foraminifera

\section{LITHOLOGY}

The description of the interval $60^{\prime}-1050^{\prime}(18-312 \mathrm{~m})$ is based on 39 ditch samples.

$60^{\prime}-90^{\prime}$ Sand, medium- to coarse-grained. Lignite occurs in the upper part of the interval. 
90'-225' Clay, dark brown, micaceous, non-calcareous.

$225^{\prime}-240^{\prime}$ Lignite. Medium- to coarse-grained sand is present in small amounts.

$240^{\prime}-360^{\prime}$ Sand, medium- to coarse-grained. Lignite is present in minor quantities. Micaceous clay is found in the lower part of the interval.

$360^{\prime}-450^{\prime}$ Clay, dark brown, micaceous, non-calcareous.

$450^{\prime}-660^{\prime}$ Sand, medium- to coarse-grained, alternating with dark brown, micaceous clay. From $470^{\prime}-660^{\prime}$ are found fine-grained, grey, highly calcareous sandstone concretions, often with fragments of molluscs.

$660^{\prime}-1050^{\prime}$ Clay, dark brown, micaceous, slightly calcareous. From 750'-1050' with an increasing content of glauconite.

\section{BIOSTRATIGRAPHY}

The described interval is subdivided into an upper section from $60^{\prime}-660^{\prime}$ consisting mainly of sandy deposits with scattered layers of lignite and clay, and a lower section from $660^{\prime}-1050^{\prime}$ with glauconitic clay.

The section $60^{\prime}-660^{\prime}(18-201 \mathrm{~m})$.

Foraminifera have only been found in the sample $470^{\prime}-490^{\prime}$. The fauna is poor in number of individuals as well as in number of species. The following species are characteristic:

Loxostomum sinuosum CUSHMAN 1936

Cribrononion heteroporum (EGGER 1857)

Elphidiella minuta (REUss 1865)

Loxostomum sinuosum has been recorded from a number of borings in Jylland in layers belonging to the Klintinghoved Formation, in which it is rare and rather uncharacteristic, and in the lower part of the Arnum Formation, while Elphidiella minuta has been recorded from the Arnum Formation only (KRISTOFFERSEN 1972). Therefore the present fauna is referred to the lower part of the Arnum Formation.

Besides the poor foraminiferal fauna, marine indicators were found in a number of samples within the interval $450^{\prime}-690^{\prime}$ in the form of marine molluscs. The samples are of a rather bad quality, however, and therefore the majority of the molluscs are assumed to be cavings from one or a few marine layers situated in the upper part of the interval with marine molluscs $\left(450^{\prime}-690^{\prime}\right)$, thus including the section $470^{\prime}-490^{\prime}$ with the described foraminiferal fauna. L. BANKE RASMUSSEN has examined the molluscs, and he has made the following remarks:

"From the interval $490^{\prime}-690^{\prime}$ in Nøvling No. 1 a number of fragments of marine molluscs have been collected, some of which it has been possible to identify. In the sample $490^{\prime}-510^{\prime}$ was found a.o. Nucula sp., Leda westendorpii (NYsT \& WeSTENDORP), Hinia schlotheimi (BeYRICH) and Aquilofusus cf. grippi (KAUTSKY). The sample 540'-570' contained mainly fragments of pelecypods, especially of Nucula cf. nucleus (LINNÉ), and a few shells of Leda pygmaea (MÜNSTER) and fragments of Spisula subtruncata (DA CosTA) var. The sample $570^{\prime}-600^{\prime}$ was characterized by numerous fragments of a Nucula (presumably $N$. nucleus). The same holds true for the samples $600^{\prime}-630^{\prime}$ and $630^{\prime}-660^{\prime}$. In the sample $600^{\prime}-630^{\prime}$ also a fragment of a Ringicula was found. A larger number of species were present in the sample $660^{\prime}-690^{\prime}$, in which occurred a.o. Nucula sp., Leda westendorpii, Yoldia cf. glaberrima (Münster), Laevicardium sp., Spisula subtruncata, Dentalium sp., Natica sp., Hinia schlotheimi, Admete fusiformis (CANTraINE), Turricula steinvorthi (v. KOENEN), Acteon sp., and Ringicula buccinea (BROCCHI). Besides these molluscs, also otoliths and shark's teeth were found in some of the samples.

All the species named are known from the Arnum Formation (see SORGENFREI 1958), and the shell remains found must be considered to originate from molluscan faunas in marine beds of this formation. A large dominance of Nucula does not, however, seem to be characteristic of any of the earlier published faunas from the Danish Miocene. On the other hand, there is hardly any doubt that the shell remains in the samples of Nøvling originate in the Arnum beds and thus are Miocene. But it is uncertain whether more than one shell-bearing horizon is represented."

The section $60^{\prime}-660^{\prime}$ must be interpreted as a mainly non-marine series with one or a few marine layers. The marine beds are referred to the Arnum Formation, while the nonmarine beds are referred to the Ribe Formation and the Odderup Formation (fig. 14). 
The boundary between the Tertiary and the Quaternary is located somewhere in the uppermost part of the boring $\left(0^{\prime}-60^{\prime}\right)$, from which interval no samples are available. In a number of water supply and lignite borings situated 4-6 kilometers from the Nøvling boring the Tertiary-Quaternary boundary was found 2-6 meters below ground, and consequently it is reasonable to suppose this boundary to be at a corresponding depth in the Nøvling boring.

The section 660'-1050' (201-312 m).

Foraminifera are present in all samples within the section except in the uppermost one from $660^{\prime}-690^{\prime}$. The fauna in the upper part $\left(690^{\prime}-780^{\prime}\right)$ is poor in individuals and species and consists of species that also occur in the lower part. The following species are characteristic:

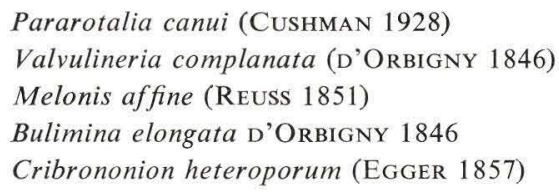

The lower part of the section $\left(780^{\prime}-1050^{\prime}\right)$ is rather rich in individuals and species. In addition to the already mentioned species from the upper part the following species are characteristic:

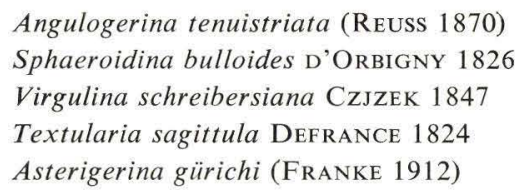

Angulogerina tenuistriata, Melonis affine and Bulimina elongata dominate the fauna, while Asterigerina gürichi, which occurs in the interval $870^{\prime}-1050^{\prime}$, shows relatively low frequencies except in the lowermost sample $\left(1020^{\prime}-1050^{\prime}\right)$, in which it constitutes about $25 \%$ of the fauna. This Asterigerina fauna is referred to the basal part of the Upper Oligocene, which is in accordance with the interpretation of the Oligocene Asterigerina Horizon in the Niederrhein area in Germany (ELLERMANN 1960 and INDANS 1965). The entire fossiliferous interval $690^{\prime}-1050^{\prime}$ shows a rather good faunistic resemblance with Upper Oligocene faunas from Brejning (DINESEN 1959) and the Niederrhein area, especially by the occurrence of the characteristic species Virgulina schreibersiana and Pararotalia canui.

The lowermost sample $\left(1020^{\prime}-1050^{\prime}\right)$ contains a large number of Eocene foraminifera coming from the light grey Eocene marl which is represented in the lower part of this interval (see DINESEN p. 80). The boundary between the Eocene and Oligocene is situated within this sample interval, and from the gamma ray log it is easily recognized at a depth of $312 \mathrm{~m}$ below the Kelly Bushing.

Beds of Middle Oligocene age have not been identified, but recordings of the following species might possibly suggest the presence of Middle Oligocene:

Alabamina perlata (ANDREAE 1884)

Turrilina alsatica (ANDREAE 1884)

In an oral communication, however, ARNE DINESEN has informed me that Alabamina perlata may occur already in the Upper Eocene Søvind Marl. Furthermore, the Turrilina forms present show a variation quite normal for the Upper Eocene, and consequently the presence of Middle Oligocene beds is considered doubtful. 


\section{CONCLUSION}

The Oligocene-Miocene series described has been subdivided into a lower marine part $\left(660^{\prime}-1050^{\prime}\right)$ containing an Upper Oligocene foraminiferal fauna, and an upper, mainly non-marine part $\left(60^{\prime}-660^{\prime}\right)$ with one or a few marine layers with Miocene foraminifera and molluscs. The marine Miocene layers are referred to the Arnum Formation while the non-marine parts are referred to the Ribe Formation and the Odderup Formation (see fig. 14).

Beds of Middle Oligocene age have not been recognized. Marine layers belonging to the Lower Miocene Klintinghoved Formation have not been found either. The younger part of the Miocene corresponding to the Hodde and Gram Formations is missing.

The Tertiary-Quaternary boundary is supposed to be located between 2 and 6 meters below ground.

\section{LITTERATUR}

Dinesen, A., se Larsen, G. og Dinesen, A.

EllermanN, C., 1960. Foraminiferen aus dem Oligozän des Schachtes Kapellen (Niederrhein) mit Variationsstatistik von Elphidium subnodosum (RoEmer). - Geol. Jb., Bd. 77, pp. 645-710. - Hannover.

INDANS, J., 1965. Mikrofaunistisches Normalprofil durch das marine Tertiär des Niederrheinischen Bucht. - Forsch. ber. Land Nordrhein-Westfalen, nr. 1484. - Köln.

K.ristoffersen, F. NyhuUs, 1972. Foraminiferzonering i det jyske miocæn. - Dansk geol. Foren., Årsskrift for 1971, side 79-85. - København.

Larsen, G. \& Dinesen, A., 1959. Vejle Fjord Formationen ved Brejning. Sedimenterne og foraminiferfaunaen. (oligocæn-miocæn). - Danmarks geol. Unders. II. række, nr. 82. København.

Sorgenfrei, T., 1958. Molluscan Assemblages from the Marine Middle Miocene of South Jutland and their Environments. - Danmarks geol. Unders. II. række, nr. 79. - København. 


\title{
EOCÆN I NØVLING NR. 1
}

\author{
(312-427 M)
}

af

\section{Arne Dinesen}

INDLEDNING

Under de oligocæne lag, som er behandlet i det foregående afsnit af F. NyHUUs KRISTOFFERSEN, gennemboredes en serie af fede mergel- og lerbjergarter med indslag af vulkansk aske. Serien må på grund af den stratigrafiske placering, de lithologiske træk og foraminiferindholdet henføres til eocæn.

Prøvematerialet består af 14 skylleprøver, der er udtaget med et interval på $30^{\prime}$ mellem 1020' og 1440'. Med støtte i den optagne gamma ray log lader en stratigrafisk inddeling sig gennemføre i et vist omfang. Seriens top og basis findes ved henholdsvis $312 \mathrm{~m}$ og $427 \mathrm{~m}$. Mægtigheden andrager således $115 \mathrm{~m}$, idet der dog hersker tvivl, om de nederste $10 \mathrm{~m}(417-427 \mathrm{~m})$ bør henføres til paleocæn istedet for til eocæn.

\section{LITHOLOGI}

Prøverne blev beskrevet på borestedet af O. MiChELSEN, hvis iagttagelser senere er suppleret af F. NyHUUS KRISTOFFERSEN og undertegnede. Beskrivelsen lyder således:

( $-1020^{\prime}$ : Glimmerler, mørk brungrå, finsandet, med enkelte skalfragmenter).

$1020^{\prime}-1050^{\prime}$ : Ler, grå, let finsandet, med enkelte glaukonitkorn og med en del skalfragmenter, samt Mergel, hvidlig, der er indarbejdet som små stumper og slirer i den grå lerbjergart.

$1050^{\prime}-1080^{\prime}$ : Mergel, hvidlig til lys brunlig grå, sjældent lys rødlig brun.

$1080^{\prime}-1170^{\prime}$ : Mergel, dels lys brunlig grå, dels lys rødlig brun.

$1170^{\prime}-1350^{\prime}$ : Ler, grå til grønlig grå, stedvis mørk (især i prøven $1290^{\prime}-1320^{\prime}$ ). (Mergel af lysere farve som ovenfor er antagelig »nedfald $«$ ).

$1350^{\prime}-1440^{\prime}$ : Ler, dels som ovenfor, dels teglstensrød, samt (fra 1380' og nedefter) Ler, mørk grå, pyritrig, og vulkansk aske.

$\left(1440^{\prime}-\quad\right.$ : Ler, grå, let finsandet, skifret).

\section{FORAMINIFERINDHOLD}

I tabellen er anført foraminiferanalyser af de 14 skylleprøver mellem 1020' og $1440^{\prime}$. Analyserne er foretaget på 3 slæmmerest-fraktioner fra hver prøve, 


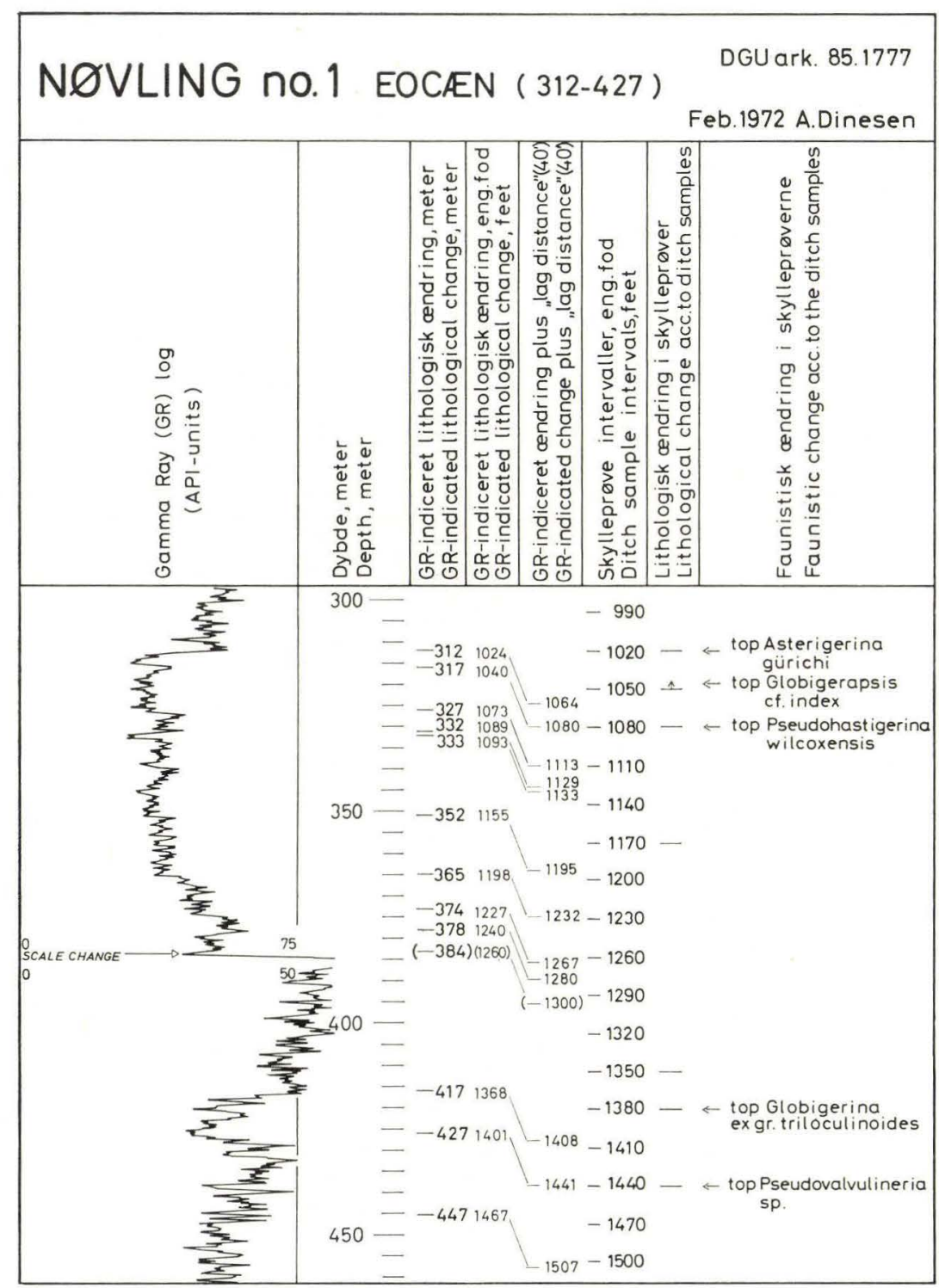

Fig. 15

nemlig fraktion $1(0.10-0.25 \mathrm{~mm})$, fraktion $2(0.25-0.50 \mathrm{~mm})$ og fraktion 3 $(0.50-1.00 \mathrm{~mm})$. Navnlig i fraktion 3 optræder eksemplarer, der er mindre end angivet af den nedre fraktionsgrænse.

Som følge af den anvendte boreteknik vil foraminifersammensætningen i de enkelte prøver være præget af »nedfald « (caving) fra de overliggende lag. Det er i tabellen søgt at skelne mellem eocæne og yngre former, idet talangivelserne for de sidstnævnte er sat i parentes. Former som Textularia $c f$. sagittula, 


\begin{tabular}{|c|c|c|c|c|c|c|c|c|c|c|c|c|c|c|c|}
\hline & 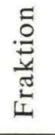 & ஜn & $\begin{array}{l}\dot{0} \\
\stackrel{\infty}{0} \\
\grave{1}\end{array}$ & $\stackrel{0}{\vdots}$ & $\stackrel{\text { ò }}{\stackrel{1}{1}}$ & $\stackrel{20}{\stackrel{2}{1}}$ & ¿े̀ & 仓े & $\stackrel{1}{i}$ & ڤे & के & ì & $\begin{array}{l}\dot{\infty} \\
\stackrel{\infty}{7} \\
\stackrel{1}{1}\end{array}$ & $\frac{\grave{9}}{\frac{1}{1}}$ & 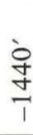 \\
\hline 1. Textularia cf. sagittula & 1 & $\ldots$ & (3) & (1) & . & . & . & (1) & (1) & . & . & . & . & . & . \\
\hline \multirow[t]{2}{*}{ Defrance } & 2 & (1) & (1) & . & $\cdots$ & . & (7) & (2) & . & . & . & . & . & . & . \\
\hline & 3 & . & $\cdots$ & . & $\cdots$ & . & . & $\cdots$ & . & . & . & $\cdots$ & $\cdots$ & $\cdots$ & . \\
\hline \multirow{3}{*}{$\begin{array}{l}\text { 2. Spiroplectammina carinata } \\
\text { (D'ORBIGNY) }\end{array}$} & 1 & . & $\ldots$ & $\ldots$ & $\ldots$ & . & . & $\ldots$ & . & . & . & . & . & . & . \\
\hline & 2 & 2 & 1 & 3 & 4 & 1 & . & 1 & $\ldots$ & 1 & . & 1 & 1 & 1 & . \\
\hline & 3 & . & . & . & $\cdots$ & . & . & . & $\cdots$ & . & . & 1 & $\cdots$ & . & . \\
\hline \multirow[t]{3}{*}{ 3. Plectina sp. (AD-B173) } & 1 & . & . & 3 & . & . & 1 & . & $\cdots$ & . & . & . & . & . & . \\
\hline & 2 & 1 & 4 & 3 & 4 & 2 & $\cdots$ & 2 & $\cdots$ & 1 & . & . & . & . & . \\
\hline & 3 & . & . & $\cdots$ & . & . & . & $\cdots$ & $\cdots$ & . & . & . & . & . & . \\
\hline \multirow[t]{3}{*}{ 4. Pseudoclavulina sp. (AD-B159) } & 1 & . & $\cdots$ & . & . & $\cdots$ & . & $\cdots$ & $\cdots$ & . & . & . & . & 4 & . \\
\hline & 2 & . & . & . & . & . & . & . & . & . & . & $\cdots$ & . & . & . \\
\hline & 3 & . & . & . & . & . & . & . & . & . & . & . & . & . & . \\
\hline \multirow[t]{3}{*}{ 5. Arenobulimina sp. (AD-B163) } & 1 & $\ldots$ & 1 & 2 & $\ldots$ & 2 & 2 & 1 & $\ldots$ & . & . & . & $\ldots$ & . & . \\
\hline & 2 & . & $\cdots$ & 1 & 3 & 2 & 2 & 1 & . & 1 & 1 & . & 1 & . & . \\
\hline & 3 & $\ldots$ & $\ldots$ & . & $\ldots$ & . & . & . & $\ldots$ & . & . & . & . & . & . \\
\hline \multirow{3}{*}{$\begin{array}{l}\text { 6. Andre aggl. foram. - Other } \\
\text { arenaceous forams. }\end{array}$} & 1 & (3) & $\ldots$ & 1 & 1 & 4 & $\ldots$ & 2 & . & 1 & . & 1 & 2 & 2 & 11 \\
\hline & 2 & (3) & $\ldots$ & $\ldots$ & 5 & 1 & 1 & $\ldots$ & 1 & . & . & 1 & 4 & . & . \\
\hline & 3 & . & $\cdots$ & . & . & . & $\ldots$ & . & $\ldots$ & . & . & . & . & . & . \\
\hline \multirow[t]{3}{*}{ 7. Miliolidae } & 1 & $\ldots$ & 8 & 4 & 7 & 3 & 2 & 1 & 5 & 1 & 8 & . & 4 & $\ldots$ & 1 \\
\hline & 2 & 5 & 2 & . & 2 & 3 & 3 & . & 1 & . & . & . & . & . & . \\
\hline & 3 & 3 & 1 & $\ldots$ & $\ldots$ & $\ldots$ & 1 & $\ldots$ & $\ldots$ & . & . & . & . & . & . \\
\hline \multirow[t]{3}{*}{ 8. Stilostomella sp. sp. } & 1 & $\ldots$ & $\ldots$ & . & 3 & . & 2 & $\ldots$ & 6 & 1 & 8 & . & 2 & . & 1 \\
\hline & 2 & $\cdots$ & . & . & 1 & 1 & . & . & $\cdots$ & . & . & . & 1 & . & . \\
\hline & 3 & . & $\cdots$ & . & $\cdots$ & . & $\cdots$ & $\cdots$ & . & $\cdots$ & . & $\cdots$ & $\cdots$ & $\cdots$ & . \\
\hline \multirow{3}{*}{$\begin{array}{l}\text { 9. Vaginulinopsis decoratus } \\
\text { (REUSs) }\end{array}$} & 1 & $\ldots$ & . & . & . & . & . & $\ldots$ & $\ldots$ & . & . & . & . & . & . \\
\hline & 2 & 1 & 1 & $\ldots$ & . & 8 & 2 & 2 & $\ldots$ & . & . & . & 1 & 1 & . \\
\hline & 3 & 1 & $\ldots$ & $\ldots$ & $\ldots$ & 1 & 6 & 3 & $\ldots$ & $\ldots$ & $\ldots$ & $\ldots$ & $\ldots$ & $\ldots$ & . \\
\hline \multirow{3}{*}{$\begin{array}{l}\text { 10. Andre Lagenidae - Other } \\
\text { Lagenidae }\end{array}$} & 1 & 7 & 10 & 9 & 16 & 15 & 5 & 7 & 10 & 12 & 11 & 1 & 8 & 7 & 5 \\
\hline & 2 & 34 & 72 & 72 & 88 & 62 & 64 & 72 & 15 & 19 & 15 & 9 & 15 & 4 & 3 \\
\hline & 3 & 8 & 34 & 13 & 20 & 11 & 6 & 12 & 1 & 1 & $\ldots$ & 1 & 2 & $\ldots$ & . \\
\hline \multirow[t]{3}{*}{ 11. Polymorphinidae } & 1 & $\ldots$ & 1 & 5 & 4 & 3 & 3 & 2 & 2 & 7 & 3 & 1 & 2 & $\ldots$ & . \\
\hline & 2 & 8 & 7 & 4 & 12 & 2 & 5 & 5 & $\ldots$ & 3 & 1 & 1 & 1 & $\ldots$ & $\ldots$ \\
\hline & 3 & 3 & 1 & $\ldots$ & $\ldots$ & $\ldots$ & 1 & $\ldots$ & $\ldots$ & $\ldots$ & $\ldots$ & $\ldots$ & $\ldots$ & $\ldots$ & . \\
\hline
\end{tabular}




\begin{tabular}{|c|c|c|c|c|c|c|c|c|c|c|c|c|c|c|c|}
\hline & 点 & $\stackrel{\circ}{\varrho}$ & $\stackrel{\grave{\infty}}{\stackrel{0}{0}}$ & $\stackrel{0}{\exists}$ & $\stackrel{\grave{Q}}{\overline{1}}$ & $\stackrel{?}{\Xi}$ & 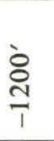 & $\stackrel{\text { Ò }}{i}$ & 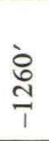 & ঙे & 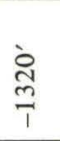 & $\begin{array}{l}\dot{0} \\
\stackrel{n}{n} \\
i\end{array}$ & 产 & $\frac{\grave{1}}{\frac{1}{1}}$ & 守 \\
\hline \multirow[t]{3}{*}{ 12. Turrilina sp. sp. } & 1 & 20 & 3 & 2 & 4 & 2 & 3 & 2 & 3 & 3 & 7 & 1 & 4 & 3 & 9 \\
\hline & 2 & . & . & . & . & . & . & . & . & 1 & . & . & $\ldots$ & . & . \\
\hline & 3 & . & . & $\ldots$ & . & . & . & $\ldots$ & .. & $\ldots$ & . & $\ldots$ & . & . & . \\
\hline \multirow[t]{3}{*}{ 13. Bulimina elongata D'ORBIGNY } & 1 & (1) & . & (1) & . & . & (2) & (3) & $\ldots$ & $\ldots$ & $\ldots$ & $\ldots$ & $\ldots$ & $\ldots$ & . \\
\hline & 2 & $\ldots$ & $\ldots$ & $\ldots$ & $\ldots$ & $\ldots$ & $\ldots$ & $\ldots$ & $\ldots$ & $\ldots$ & $\ldots$ & $\ldots$ & $\ldots$ & $\ldots$ & . \\
\hline & 3 & $\ldots$ & $\ldots$ & $\ldots$ & $\ldots$ & $\ldots$ & $\ldots$ & $\ldots$ & $\ldots$ & $\ldots$ & $\ldots$ & $\ldots$ & $\ldots$ & $\ldots$ & $\ldots$ \\
\hline \multirow{3}{*}{$\begin{array}{l}\text { 14. Bulimina alsatica CUSHM. \& } \\
\text { PARKER }\end{array}$} & 1 & $\ldots$ & 2 & 2 & $\ldots$ & 1 & 3 & 2 & 1 & 1 & $\ldots$ & $\ldots$ & 2 & 7 & 2 \\
\hline & 2 & $\ldots$ & $\ldots$ & $\ldots$ & $\ldots$ & $\ldots$ & $\ldots$ & $\ldots$ & $\ldots$ & $\ldots$ & $\ldots$ & $\ldots$ & $\ldots$ & $\ldots$ & . \\
\hline & 3 & $\ldots$ & $\ldots$ & $\ldots$ & $\ldots$ & $\ldots$ & $\ldots$ & $\ldots$ & $\ldots$ & $\ldots$ & $\ldots$ & $\ldots$ & $\ldots$ & $\ldots$ & $\ldots$ \\
\hline \multirow[t]{3}{*}{ 15. Bulimina aksuatica Morosova } & 1 & 1 & 8 & 9 & 13 & 13 & 8 & 19 & 7 & 10 & 17 & 1 & 27 & 4 & 4 \\
\hline & 2 & $\ldots$ & $\ldots$ & $\ldots$ & $\ldots$ & $\ldots$ & $\ldots$ & $\ldots$ & $\ldots$ & $\ldots$ & $\ldots$ & $\ldots$ & $\ldots$ & $\ldots$ & . \\
\hline & 3 & $\ldots$ & $\ldots$ & $\ldots$ & $\ldots$ & $\ldots$ & $\ldots$ & $\ldots$ & $\ldots$ & $\ldots$ & $\ldots$ & $\ldots$ & $\ldots$ & $\ldots$ & $\ldots$ \\
\hline \multirow[t]{3}{*}{ 16. Uvigerina farinosa HANTKEN } & 1 & . & . & 1 & 1 & 2 & . & 1 & . & 2 & 1 & . & 1 & . & . \\
\hline & 2 & . & . & $\cdots$ & . & . & . & $\cdots$ & . & . & . & . & 1 & . & . \\
\hline & 3 & . & . & . & . & . & . & $\ldots$ & . & $\ldots$ & . & $\ldots$ & $\ldots$ & .. & . \\
\hline \multirow[t]{3}{*}{ 17. Uvigerina costellata MoRosova } & 1 & . & . & . & . & . & . & $\ldots$ & $\ldots$ & $\ldots$ & 1 & $\ldots$ & $\ldots$ & $\ldots$ & . \\
\hline & 2 & $\ldots$ & $\ldots$ & $\ldots$ & $\ldots$ & $\ldots$ & $\ldots$ & 1 & $\ldots$ & 1 & $\ldots$ & $\ldots$ & $\ldots$ & $\ldots$ & . \\
\hline & 3 & . & $\ldots$ & $\ldots$ & .. & $\ldots$ & . & $\ldots$ & $\ldots$ & $\ldots$ & $\ldots$ & $\ldots$ & . & $\ldots$ & . \\
\hline \multirow{3}{*}{$\begin{array}{l}\text { 18. Angulogerina ex gr. gracilis } \\
\text { (REuss) }\end{array}$} & 1 & (10) & $\ldots$ & $\ldots$ & $\ldots$ & $\ldots$ & (2) & (5) & .. & (1) & (1) & $\ldots$ & $\ldots$ & $\ldots$ & . \\
\hline & 2 & (1) & $\ldots$ & $\ldots$ & $\ldots$ & $\ldots$ & $\ldots$ & $\ldots$ & $\ldots$ & $\ldots$ & $\ldots$ & $\ldots$ & $\ldots$ & $\ldots$ & . \\
\hline & 3 & $\ldots$ & $\ldots$ & $\ldots$ & $\ldots$ & $\ldots$ & . & $\ldots$ & . & $\ldots$ & $\ldots$ & . & $\ldots$ & $\ldots$ & . \\
\hline \multirow{3}{*}{$\begin{array}{l}\text { 19. Angulogerina abbreviata } \\
\text { (TERQUEM) }\end{array}$} & 1 & $\ldots$ & $\ldots$ & $\ldots$ & $\ldots$ & $\ldots$ & $\ldots$ & $\ldots$ & $\ldots$ & $\ldots$ & $\ldots$ & $\ldots$ & $\ldots$ & 1 & 5 \\
\hline & 2 & $\ldots$ & $\ldots$ & $\ldots$ & $\ldots$ & $\ldots$ & $\ldots$ & $\ldots$ & $\ldots$ & $\ldots$ & . & $\ldots$ & $\ldots$ & $\ldots$ & . \\
\hline & 3 & $\ldots$ & $\ldots$ & $\ldots$ & $\ldots$ & $\ldots$ & $\ldots$ & $\ldots$ & $\ldots$ & $\ldots$ & $\ldots$ & $\ldots$ & $\ldots$ & $\ldots$ & . \\
\hline \multirow[t]{3}{*}{ 20. Reusella limbata (TERQUEM) } & 1 & . & . & . & . & . & . & $\ldots$ & . & . & . & . & $\ldots$ & . & 2 \\
\hline & 2 & . & . & . & . & . & . & . & . & . & . & $\ldots$ & $\ldots$ & . & . \\
\hline & 3 & . & . & . & . & . & . & $\ldots$ & . & $\ldots$ & . & . & $\ldots$ & . & . \\
\hline \multirow[t]{3}{*}{ 21. Bolivina sp. sp. } & 1 & 1 & 2 & 3 & 5 & 2 & 2 & . & 2 & 2 & 2 & . & 4 & . & . \\
\hline & 2 & . & $\cdots$ & . & . & . & . & . & . & . & . & . & . & . & . \\
\hline & 3 & . & . & . & .. & . & . & . & . & . & . & . & . & . & . \\
\hline \multirow[t]{3}{*}{ 22. Aragonia compressa OLsson } & 1 & . & . & . & . & .. & . & . & . & . & $\ldots$ & .. & . & 1 & . \\
\hline & 2 & . & . & . & . & . & . & $\ldots$ & . & $\ldots$ & $\ldots$ & $\ldots$ & . & . & . \\
\hline & 3 & $\ldots$ & $\ldots$ & $\ldots$ & $\ldots$ & . & $\ldots$ & $\ldots$ & $\ldots$ & $\ldots$ & $\ldots$ & . & $\ldots$ & . & .. \\
\hline
\end{tabular}




\begin{tabular}{|c|c|c|c|c|c|c|c|c|c|c|c|c|c|c|c|}
\hline & 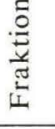 & $\stackrel{\circ}{1}$ & $\stackrel{\circ}{\stackrel{0}{1}}$ & $\stackrel{\varrho}{\ni}$ & $\stackrel{1}{1}$ & 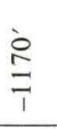 & 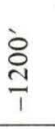 & 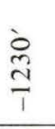 & 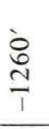 & ㅎำ & $\stackrel{\text { ֻे }}{\stackrel{1}{1}}$ & i⿱⺈ & $\underset{\substack{\infty \\
\hdashline}}{\rightarrow}$ & $\frac{\operatorname{s}}{\frac{1}{1}}$ & $\frac{\overbrace{}^{\prime}}{1}$ \\
\hline \multirow{3}{*}{$\begin{array}{l}\text { 23. Andre Buliminidae - Other } \\
\text { Buliminidae }\end{array}$} & 1 & . & 1 & 4 & 3 & . & . & . & .. & $\cdots$ & . & . & 2 & . & . \\
\hline & 2 & $\cdots$ & . & . & $\cdots$ & 1 & . & $\cdots$ & . & $\cdots$ & $\cdots$ & . & . & $\cdots$ & . \\
\hline & 3 & $\ldots$ & $\ldots$ & $\ldots$ & $\ldots$ & $\ldots$ & $\ldots$ & $\ldots$ & $\ldots$ & $\ldots$ & $\ldots$ & $\ldots$ & $\ldots$ & $\ldots$ & . \\
\hline \multirow[t]{3}{*}{ 24. Cassidulina sp. sp. } & 1 & 7 & 3 & 1 & 1 & 1 & 3 & 1 & 2 & 1 & 4 & 1 & 3 & 2 & . \\
\hline & 2 & 1 & . & . & $\cdots$ & . & . & $\cdots$ & . & $\cdots$ & $\cdots$ & . & $\cdots$ & $\cdots$ & . \\
\hline & 3 & $\cdots$ & . & $\cdots$ & $\cdots$ & $\cdots$ & $\cdots$ & $\cdots$ & . & $\cdots$ & $\cdots$ & . & . & $\cdots$ & . \\
\hline \multirow{3}{*}{$\begin{array}{l}\text { 25. Sphaeroidina bulloides } \\
\text { D'ORBIGNY }\end{array}$} & 1 & (5) & . & $\cdots$ & $\ldots$ & $\ldots$ & $\ldots$ & $\ldots$ & .. & $\ldots$ & $\ldots$ & $\ldots$ & $\ldots$ & $\ldots$ & .. \\
\hline & 2 & (9) & $\ldots$ & $\ldots$ & $\ldots$ & $\ldots$ & $\ldots$ & (1) & .. & $\ldots$ & $\ldots$ & $\ldots$ & $\ldots$ & $\ldots$ & .. \\
\hline & 3 & $\ldots$ & $\ldots$ & $\ldots$ & $\cdots$ & $\ldots$ & . & $\ldots$ & .. & $\ldots$ & $\cdots$ & . & . & $\ldots$ & . \\
\hline \multirow[t]{3}{*}{ 26. Nonion affine (REUSS) } & 1 & (4) & $\ldots$ & $\ldots$ & $\ldots$ & (2) & (2) & $\ldots$ & .. & (1) & (1) & $\ldots$ & $\ldots$ & $\ldots$ & .. \\
\hline & 2 & $\ldots$ & $\ldots$ & $\ldots$ & $\ldots$ & $\ldots$ & $\ldots$ & $\ldots$ & .. & $\ldots$ & $\ldots$ & $\ldots$ & $\ldots$ & $\ldots$ & . \\
\hline & 3 & $\ldots$ & $\ldots$ & $\ldots$ & $\ldots$ & $\ldots$ & $\ldots$ & $\ldots$ & . & $\ldots$ & $\ldots$ & $\ldots$ & .. & $\ldots$ & $\ldots$ \\
\hline \multirow{3}{*}{ 27. Pullenia sp. sp. } & 1 & 2 & 5 & 4 & 4 & 3 & 6 & 7 & 6 & 4 & 8 & $\ldots$ & 7 & 2 & 1 \\
\hline & 2 & 1 & 1 & $\ldots$ & 3 & 2 & $\ldots$ & 1 & 1 & 1 & $\ldots$ & 1 & 1 & 1 & . \\
\hline & 3 & $\ldots$ & $\ldots$ & $\ldots$ & $\ldots$ & $\ldots$ & $\ldots$ & $\ldots$ & .. & $\ldots$ & $\ldots$ & $\ldots$ & $\ldots$ & $\ldots$ & $\ldots$ \\
\hline \multirow[t]{3}{*}{ 28. Valvulineria sp. sp. } & 1 & (2) & $\cdots$ & $\cdots$ & (1) & $\cdots$ & . & $\cdots$ & . & $\cdots$ & $\cdots$ & $\cdots$ & . & . & . \\
\hline & 2 & (1) & . & $\cdots$ & $\cdots$ & . & (1) & $\ldots$ & .. & $\ldots$ & $\cdots$ & . & . & . & . \\
\hline & 3 & $\cdots$ & . & . & $\cdots$ & $\cdots$ & $\cdots$ & $\cdots$ & . & $\cdots$ & $\cdots$ & . & . & $\cdots$ & . \\
\hline \multirow{3}{*}{ 29. Gyroidina sp. sp. } & 1 & 4 & 3 & 12 & 11 & 10 & 17 & 9 & 4 & 7 & 7 & 3 & 17 & 3 & 2 \\
\hline & 2 & 3 & 18 & 13 & 12 & 5 & 7 & 2 & . & 2 & $\cdots$ & . & 4 & $\cdots$ & 1 \\
\hline & 3 & $\cdots$ & $\cdots$ & . & $\cdots$ & $\cdots$ & $\cdots$ & $\cdots$ & . & $\cdots$ & $\cdots$ & $\cdots$ & . & $\cdots$ & $\cdots$ \\
\hline \multirow[t]{3}{*}{ 30. Eponides umbonatus (REUss) } & 1 & $\cdots$ & 2 & 4 & 12 & 6 & 7 & 5 & 5 & 6 & 6 & 3 & 6 & 3 & 13 \\
\hline & 2 & . & 1 & 5 & 5 & 7 & 4 & 2 & . & 3 & $\cdots$ & . & . & $\cdots$ & . \\
\hline & 3 & . & .. & . & $\cdots$ & $\cdots$ & . & $\cdots$ & . & . & . & . & . & $\cdots$ & . \\
\hline \multirow{3}{*}{$\begin{array}{l}\text { 31. Cancris auriculus var. } \\
\text { primitivus CUSHMAN \& TODD }\end{array}$} & 1 & . & . & $\cdots$ & $\cdots$ & $\cdots$ & . & $\cdots$ & . & $\cdots$ & $\cdots$ & $\cdots$ & $\cdots$ & 1 & . \\
\hline & 2 & . & .. & .. & . & $\cdots$ & . & . & . & . & . & $\cdots$ & $\cdots$ & . & . \\
\hline & 3 & $\cdots$ & . & $\cdots$ & $\cdots$ & $\cdots$ & . & $\cdots$ & . & $\cdots$ & $\cdots$ & . & . & . & . \\
\hline \multirow[t]{3}{*}{ 32. Cibidides cf. tenellus (REuss) } & 1 & 19 & 26 & 33 & 45 & 36 & 34 & 29 & 20 & 25 & 32 & 10 & 29 & 7 & 15 \\
\hline & 2 & 20 & 54 & 51 & 84 & 56 & 34 & 38 & 7 & 19 & 12 & . & 9 & 1 & 5 \\
\hline & 3 & . & 2 & . & $\cdots$ & 1 & . & . & . & . & . & . & . & . & . \\
\hline \multirow[t]{3}{*}{ 33. Cibicides ungerianus D'ORBIGNY } & 1 & $\cdots$ & . & 2 & 1 & 1 & . & 2 & . & 1 & $\cdots$ & . & . & 9 & 4 \\
\hline & 2 & 3 & 9 & 6 & 13 & 1 & 3 & 2 & . & 1 & 1 & $\ldots$ & $\ldots$ & 2 & $\ldots$ \\
\hline & 3 & $\ldots$ & $\ldots$ & $\ldots$ & $\ldots$ & $\ldots$ & $\ldots$ & $\ldots$ & . & $\ldots$ & $\ldots$ & $\ldots$ &.. & $\ldots$ & $\ldots$ \\
\hline
\end{tabular}




\begin{tabular}{|c|c|c|c|c|c|c|c|c|c|c|c|c|c|c|c|}
\hline & 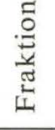 & $\stackrel{\circ}{1}$ & $\stackrel{\infty}{\infty}$ & $\stackrel{\circ}{\doteqdot}$ & $\stackrel{\text { ò }}{\text { T }}$ & $\stackrel{\circ}{\frac{1}{1}}$ & $\underset{1}{\stackrel{\text { }}{1}}$ & $\underset{\infty}{\stackrel{\infty}{1}}$ & 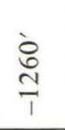 & $\stackrel{\stackrel{\circ}{7}}{7}$ & ì & $\stackrel{\substack{n \\
m}}{i}$ & $\underset{\infty}{\infty}$ & $\stackrel{\text { 웜 }}{\frac{1}{1}}$ & 守 \\
\hline \multirow[t]{3}{*}{ 34. Cibicides sulzensis (HerrmanN) } & 1 & 2 & 5 & 3 & . & 8 & 5 & 2 & 1 & 2 & .. & $\ldots$ & . & .. & 2 \\
\hline & 2 & . & 1 & 2 & 3 & 7 & 3 & 3 & . & 1 & . & $\cdots$ & . & . & $\ldots$ \\
\hline & 3 & $\cdots$ & . & . & . & . & $\ldots$ & $\cdots$ & . & . & . & $\ldots$ & . & . & . \\
\hline \multirow[t]{3}{*}{ 35. Cibicides (?) sp. } & 1 & . & 3 & 1 & . & 2 & 1 & . & . & 2 & . & $\ldots$ & 2 & . & 3 \\
\hline & 2 & 1 & . & 1 & 1 & 2 & 2 & 3 & . & . & 1 & $\ldots$ & . & . & . \\
\hline & 3 & . & . & . & . & . & . & . & . & . & . & $\ldots$ & . & . & . \\
\hline \multirow{3}{*}{$\begin{array}{l}\text { 36. Cibicides dutemplei } \\
\text { (D'OrBIGNY) }\end{array}$} & 1 & 1 & . & . & . & 1 & 3 & . & . & 1 & . & 1 & . & . & $\ldots$ \\
\hline & 2 & $\cdots$ & $\cdots$ & 1 & $\cdots$ & . & . & 1 & $\cdots$ & $\cdots$ & $\cdots$ & $\cdots$ & $\cdots$ & . & . \\
\hline & 3 & . & . & . & . & . & $\ldots$ & . & . & . & $\ldots$ & $\ldots$ & $\ldots$ & . & $\ldots$ \\
\hline \multirow[t]{3}{*}{ 37. Cibicides sp. sp. } & 1 & 21 & 4 & 15 & 10 & 4 & 8 & 4 & 14 & 7 & 7 & 5 & 1 & 19 & 19 \\
\hline & 2 & 8 & 4 & 8 & 10 & 6 & 5 & 11 & 6 & 4 & 4 & 3 & 1 & 1 & 7 \\
\hline & 3 & . & . & . & . & . & . & $\ldots$ & . & . & . & $\ldots$ & . & . & . \\
\hline \multirow[t]{3}{*}{ 38. Anomalina grosserugosa } & 1 & 3 & 4 & 6 & 2 & 2 & 2 & 1 & 4 & 1 & 3 & 2 & 1 & 8 & 2 \\
\hline & 2 & 7 & 13 & . & 7 & 3 & 10 & 3 & . & 1 & 1 & $\ldots$ & 1 & . & 2 \\
\hline & 3 & . & . & . & . & . & . & $\ldots$ & . & . & . & $\ldots$ & . & . & . \\
\hline \multirow{3}{*}{ 39. Anomalina sp. sp. } & 1 & . & 4 & 4 & 2 & 4 & 2 & 4 & 4 & 1 & 6 & 2 & 5 & 6 & 8 \\
\hline & 2 & . & 2 & 8 & 8 & 6 & 2 & 4 & . & 3 & 2 & 1 & 1 & . & . \\
\hline & 3 & . & . & . & . & . & . & . & . & . & . & . & . & . & . \\
\hline \multirow[t]{3}{*}{ 40. Epistomina elegans (D'ORBIGNY) } & 1 & . & . & . & . & (1) & $\ldots$ & . & . & . & . & . & (1) & . & . \\
\hline & 2 & (6) & (2) & . & (3) & (6) & . & (2) & . & . & .. & $\ldots$ & (1) & .. & $\ldots$ \\
\hline & 3 & (2) & (1) & . & . & . & . & . & . & . & . & $\ldots$ & 1 & . & $\ldots$ \\
\hline \multirow[t]{3}{*}{ 41. Alabamina sp. sp. } & 1 & 1 & 3 & 4 & 1 & 1 & 6 & 4 & 5 & 4 & 3 & 3 & 8 & 1 & 4 \\
\hline & 2 & .. & .. & 2 & . & . & 1 & 1 & . & 1 & 1 & . & 1 & . & . \\
\hline & 3 & . & . & . & . & . & $\ldots$ & $\ldots$ & . & . & .. & $\ldots$ & . & . & . \\
\hline \multirow[t]{3}{*}{ 42. Siphonina sp. sp. } & 1 & . & 1 & . & 1 & . & 1 & $\cdots$ & . & . & 2 & . & . & 11 & 2 \\
\hline & 2 & 1 & $\ldots$ & $\ldots$ & . & $\ldots$ & . & 1 & $\ldots$ & $\ldots$ & $\ldots$ & $\ldots$ & . & $\ldots$ & $\ldots$ \\
\hline & 3 & $\ldots$ & $\ldots$ & $\ldots$ & . & $\ldots$ & $\ldots$ & . & . & $\ldots$ & . & $\ldots$ & . & $\ldots$ & $\ldots$ \\
\hline \multirow{3}{*}{$\begin{array}{l}\text { 43. Ceratobulimina contraria } \\
\text { (REUss) }\end{array}$} & 1 & (2) & (2) & $\ldots$ & (1) & $\ldots$ & $\ldots$ & (1) & $\ldots$ & $\ldots$ & $\ldots$ & $\ldots$ & (1) & $\ldots$ & $\ldots$ \\
\hline & 2 & (1) & $\ldots$ & $\ldots$ & (1) & $\ldots$ & $\ldots$ & $\ldots$ & $\ldots$ & $\ldots$ & $\ldots$ & $\ldots$ & (1) & $\ldots$ & $\ldots$ \\
\hline & 3 & $\ldots$ & $\ldots$ & $\ldots$ & $\ldots$ & $\ldots$ & . & $\ldots$ & $\ldots$ & . & $\ldots$ & $\ldots$ & $\ldots$ & $\ldots$ & $\ldots$ \\
\hline \multirow[t]{3}{*}{ 44. Asterigerina gürichi (FRANKE) } & 1 & (76) & (7) & (8) & (6) & (6) & (17) & (8) & (5) & (18) & $(7)$ & (1) & (3) & (1) & (4) \\
\hline & 2 & (83) & (11) & (16) & (15) & (15) & $(15)$ & (13) & (5) & (8) & (3) & $\ldots$ & (4) & $\ldots$ & (1) \\
\hline & 3 & $\ldots$ & (1) & $\ldots$ & $\ldots$ & $\ldots$ & $\ldots$ & $\ldots$ & $\ldots$ & $\ldots$ & $\ldots$ & $\ldots$ & $\ldots$ & $\ldots$ & $\ldots$ \\
\hline
\end{tabular}




\begin{tabular}{|c|c|c|c|c|c|c|c|c|c|c|c|c|c|c|c|}
\hline & 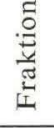 & $\begin{array}{l}\dot{8} \\
\text { oे } \\
\text { 1 }\end{array}$ & $\begin{array}{l}\grave{2} \\
\stackrel{\infty}{\circ} \\
\grave{1}\end{array}$ & $\underset{1}{\stackrel{0}{7}}$ & $\stackrel{\text { ò }}{\underset{1}{1}}$ & 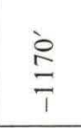 & 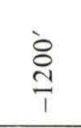 & $\begin{array}{l}\grave{\text { Iे }} \\
\text { Tे }\end{array}$ & 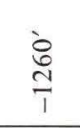 & ڤे & $\begin{array}{l}\text { ेे } \\
\text { ஸे }\end{array}$ & $\begin{array}{l}\dot{0} \\
\stackrel{m}{1}\end{array}$ & $\begin{array}{l}\grave{2} \\
\infty \\
\sim \\
T\end{array}$ & 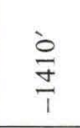 & 守 \\
\hline \multirow[t]{3}{*}{ 45. Asterigerina (?) sp. } & 1 & .. & .. & . & .. & .. & .. & .. & .. & .. & . & .. & . & 8 & 18 \\
\hline & 2 & $\ldots$ & .. & .. & .. & .. & .. & .. & .. & & . & & .. & .. & .. \\
\hline & 3 & .. & .. & .. & .. & .. & .. & .. & & $\ldots$ & .. & .. & .. & .. & .. \\
\hline \multirow{6}{*}{$\begin{array}{l}\text { 46. Andre kalkskallede benthoniske } \\
\text { foram. - Other calc. benth. } \\
\text { forams. } \\
\text { »Eocæne « benthoniske foram.- } \\
\text { »Eocene« benth. forams. }\end{array}$} & 1 & 9 & (1) & 2 & 3 & 5 & 2 & 7 & 3 & 2 & 3 & 1 & 4 & 9 & 10 \\
\hline & 2 & 1 & 5 & 3 & 5 & 7 & 3 & 3 & .. & 1 & 1 & .. & .. & .. & .. \\
\hline & 3 & .. & 2 & .. & .. & .. & .. & 1 & & .. & .. & .. & .. & .. & .. \\
\hline & 1 & 98 & 99 & 130 & 150 & 131 & 128 & 120 & 104 & 104 & 139 & 34 & 141 & 118 & 143 \\
\hline & 2 & 97 & 195 & 189 & 270 & 185 & 171 & 159 & 31 & 64 & 40 & 19 & 43 & 11 & 18 \\
\hline & 3 & 15 & 41 & 15 & 20 & 13 & 14 & 16 & 1 & 1 & .. & 2 & 3 & .. & . \\
\hline Benth. foram. fra yngre lag - & 1 & (103) & (13) & (10) & (8) & (9) & (23) & (9) & (6) & (20) & (9) & (1) & (5) & (1) & (4) \\
\hline Benth. forams. from younger & 2 & (105) & (14) & (16) & (19) & (21) & (23) & (19) & (5) & (8) & (3) & .. & (6) & & (1) \\
\hline beds & 3 & (2) & (2) & .. & . & .. & . & .. & .. & .. & .. & . & . & . & .. \\
\hline \multirow{3}{*}{$\begin{array}{l}\text { 47. Globigerina ex gr. bulloides } \\
\text { D'ORBIGNY }\end{array}$} & 1 & 45 & 127 & 154 & 108 & 200 & 199 & 210 & 138 & 198 & 98 & 200 & 117 & 86 & 108 \\
\hline & 2 & 4 & 10 & 17 & 17 & 6 & 3 & 7 & 9 & 19 & 18 & 7 & 2 & 1 & 4 \\
\hline & 3 & .. & .. & 3 & 2 & .. & & & .. & .. & .. & .. & .. & & .. \\
\hline \multirow{3}{*}{$\begin{array}{l}\text { 48. Globigerina ex gr. triloculinoides } \\
\text { PLUMMER }\end{array}$} & 1 & .. & .. & .. & .. & .. & .. & .. & .. & .. & . & .. & . & 89 & 11 \\
\hline & 2 & .. & .. & .. & .. & .. & .. & .. & .. & .. & .. & .. & .. & 5 & .. \\
\hline & 3 & .. & .. & .. & .. & .. & .. & .. & .. & .. & .. & .. & .. & .. & .. \\
\hline \multirow{3}{*}{ 49. Acarinina sp. sp. } & 1 & 89 & 30 & 19 & 34 & 42 & 45 & 80 & 57 & 25 & 50 & 54 & 41 & 43 & 32 \\
\hline & 2 & 1 & 1 & .. & 3 & .. & .. & 6 & 9 & .. & 1 & 1 & .. & 7 & 4 \\
\hline & 3 & $\ldots$ & $\ldots$ & $\ldots$ & .. & .. & .. & $\ldots$ & . & $\ldots$ & .. & .. & $\ldots$ & .. & \\
\hline \multirow[t]{3}{*}{ 50. Globorotalia sp. (AD-P33) } & 1 & .. & .. & . & .. & . & .. & .. & . & .. & . & .. & . & .. & 1 \\
\hline & 2 & .. & .. & $\ldots$ & .. & .. & .. & $\ldots$ & .. & .. & .. & .. & $\ldots$ & .. & .. \\
\hline & 3 & .. & .. & . & $\ldots$ & .. & $\ldots$ & $\ldots$ & . & & .. & .. & .. & .. & \\
\hline \multirow{3}{*}{$\begin{array}{l}\text { 51. Globigerapsis cf. index } \\
\text { (FINLAY) }\end{array}$} & 1 & $\ldots$ & 26 & 7 & 7 & .. & 3 & 3 & 5 & 3 & 13 & .. & 2 & .. & .. \\
\hline & 2 & 1 & 125 & 91 & 106 & 80 & 30 & 29 & 52 & 53 & 60 & 17 & 12 & 2 & 3 \\
\hline & 3 & .. & . & 1 & .. & .. & .. & .. & .. & 1 & .. & 1 & $\ldots$ & .. & .. \\
\hline \multirow{3}{*}{$\begin{array}{l}\text { 52. Pseudohastigerina wilcoxensis } \\
\text { (Cushm. \& Ponton) }\end{array}$} & 1 & .. & .. & 1 & 9 & 4 & 6 & 6 & 10 & 6 & 2 & 4 & 19 & 5 & 2 \\
\hline & 2 & .. & .. & .. & 1 & .. & .. & .. & .. & $\ldots$ & .. & .. & 1 & .. & .. \\
\hline & 3 & $\ldots$ & $\ldots$ & .. & .. & .. & .. & $\ldots$ & .. & $\ldots$ & .. & $\ldots$ & .. & .. & .. \\
\hline \multirow{3}{*}{$\begin{array}{l}\text { 53. Andre Globigerinaceae - } \\
\text { Other Globigerinaceae }\end{array}$} & 1 & 9 & .. & 7 & .. & 2 & & & 3 & .. & . & 3 & . & .. & .. \\
\hline & 2 & $\ldots$ & .. & .. & 4 & .. & .. & $\ldots$ & .. & .. & .. & .. &.. & .. & .. \\
\hline & 3 & .. & 5 & 1 & $\ldots$ & .. & .. & .. & .. & & .. & .. & . & .. & .. \\
\hline Planktoniske foraminiferer - & 1 & 143 & 183 & 188 & 158 & 248 & 253 & 299 & 213 & 232 & 163 & 261 & 179 & 223 & 154 \\
\hline \multirow[t]{2}{*}{ Planktonic forams. } & 2 & 6 & 136 & 108 & 131 & 86 & 33 & 42 & 70 & 72 & 79 & 25 & 15 & 15 & 11 \\
\hline & 3 & .. & 5 & 5 & 2 & . & .. & .. & . & 1 & . & 1 & $\ldots$ & $\ldots$ & $\ldots$ \\
\hline
\end{tabular}


Bulimina elongata, Angulogerina ex gr. gracilis (bl.a. A. tenuistriata), Nonion affine, Valvulineria sp. sp., Ceratobulimina contraria og Asterigerina gürichi synes utvivlsomt at stamme fra oligocænet (evt. fra den grå lerbjergart i prøve $1020^{\prime}-1050^{\prime}$ ), medens Epistomina elegans teoretisk kan være hjemmehørende i eocænet. Alle planktoniske former er opført som eocæne, skønt det ikke kan udelukkes, at Globigerina bulloides gruppen indeholder enkelte oligocæne elementer.

\section{STRATIGRAFISK VURDERING}

Lithologien i skylleprøve-afsnittet $1020^{\prime}-1440^{\prime}$ tyder på, at eocæne formationer som Søvind mergel, Lillebælt ler, Røsnæs ler og ler med vulkansk aske er repræsenteret i profilet.

Henføringen til eocæn støttes af talrige elementer i foraminiferindholdet. Ved sammenligning med andre foraminiferundersøgelser, bl.a. af kærnemateriale fra Viborg nr. 1 (se DINESEN 1972), kan tilstedeværelsen af følgende 3 zoner antages:

Zone med Globigerapsis cf. index, top i prøven 1020'-1050'

- $\quad$ - Pseudohastigerina wilcoxensis, top i prøven 1080'-1110'

- $\quad$ - Globigerina ex. gr. triloculinoides, top i prøven $1380^{\prime}-1410^{\prime}$

Det er sandsynligvis på grund af et kraftigt »nedfald « fra disse foraminiferrige zoner, at andre zoner, som f.eks. har kunnet udskilles i Viborg nr. 1, ikke kan erkendes i Nøvling boringen udfra det foreliggende materiale. Gamma ray (GR) kurven, der er sammenstillet med andre data i fig. 15, giver visse holdepunkter for en nøjere fastlæggelse af formationsgrænserne. I den følgende gennemgang af profilet er der regnet med en »lag distance« for prøvematerialet af størrelsesordenen $40^{\prime}$.

Som det ses af diagrammet, fig. 3, er »lag time« bestemt to gange under gennemboringen af det omhandlede afsnit, nemlig ved 1098' (svarende til »lag distance « $80^{\prime}$ ) og ved 1349' (svarende til »lag distance« 41'). Den øverste bestemmelse angives imidlertid at være usikker, og den er her ladt ude af betragtning.

GR-faldet ved $312 \mathrm{~m}$ må formodes at markere top af den lyse mergel, der spores - sparsomt lithologisk, men kraftigt i foraminiferindholdet - i prøven $1020^{\prime}-1050^{\prime}$. Med »lag distance« indregnet skulle merglen først vise sig på »shale shaker«, når boret er på 1064', d.v.s. i prøven $1050^{\prime}-1080^{\prime}$. Afvigelsen fra det forventede må forklares ved, at »lag distance« er mindre end antaget, eller at prøven er udtaget senere end dybdemærkningen angiver.

Den øverste foraminiferzone med Chiloguembelina sp. i Viborg nr. 1 (DINESEN, op. cit.) ser ikke ud til at være repræsenteret i Nøvling boringen, hvor prøverne $1020^{\prime}-1050^{\prime}$ (delvis) og 1050'-1080' må henføres til zonen med Globigerapsis cf. index, ligesom det er tilfældet med Søvind mergel fra typeområdet ved Horsens fjord.

Fra og med prøven $1080^{\prime}-1110^{\prime}$ optræder Pseudohastigerina wilcoxensis, som 
i Viborg nr. 1 og østjyske profiler er almindelig i Lillebælt ler og ikke mindst i lag af kalkrig ler eller mergel, der danner overgang mellem det typiske, kalkfattigere Lillebælt ler og Søvind merglen. Skønt det fundne individantal af $P$. wilcoxensis er ringe (måske på grund af store mængder »nedfald « fra Globigercpsis-zonen), er der en mulighed for, at Nøvling boringen allerede på ca. $317 \mathrm{~m}\left(1080^{\prime}\right.$ minus »lag distance « 40') passerer fra Søvind mergel ned i de nævnte overgangslag. På GR kurven ses et svagt maximum netop ved $317 \mathrm{~m}$, som kan tænkes at markere top af overgangslagene, hvis farve at dømme efter skylleprøverne dels er lidt mørkere, dels er stærkere præget af rødlige toner end Søvind merglen. Det kan dog ikke udelukkes, at top for overgangslagene med $P$. wilcoxensis først findes ved $327 \mathrm{~m}$, hvorfra GR kurven viser en stigende tendens nedefter.

Antydninger af ændringer på GR kurven ved bl.a. 332 m og 333 m står muligvis i forbindelse med vekslinger i kalkholdigheden, men først fra $352 \mathrm{~m}$ tyder de lidt højere GR-værdier på et konstant lavere kalkindhold. Antagelsen af, at top for det typiske Lillebælt ler befinder sig ved $352 \mathrm{~m}$, støttes af skylleprøverne, som indeholder flere »cuttings « med større lerindhold fra og med prøven $1170^{\prime}-1200^{\prime}$. » Lag distance « lagt til $352 \mathrm{~m}$ giver en prøvedybde $\left(1195^{\prime}\right)$, der falder inden for det nævnte prøveinterval.

Strækningen fra $365 \mathrm{~m}$ og ned til basis ved $427 \mathrm{~m}$ kan ifølge GR-kurven inddeles i 4, muligvis 5, enheder, der er karakteriseret ved følgende træk:

365-374 m: Øget GR-intensitet ved top, derunder fortsat stigende tendens.

374-378 m: GR udviser et maximum.

378-(384) m: GR minima ved top og basis (?)

(384) $-417 \mathrm{~m}$ : Ændring af skala tilslører billedet, dog tilsyneladende ret høje værdier ved top (af størrelsesorden som 374-378 m), med faldende tendens nedefter.

417-427 m: Ret lave GR-værdier.

På basis af skylleprøve-lithologien! er det meget vanskeligt at korrelere disse radioaktivitet-indicerede enheder med kendte formationer.

I Viborg nr. 1 og boringen LB 38 ved Lillebælt optræder »brogede« overgangslag i mægtigheder på henholdsvis $33 \mathrm{~m}$ og 20 m mellem typisk Røsnæs ler og typisk Lillebælt ler (se DINESEN, op. cit.). Det er sandsynligt, at tilsvarende overgangslag findes i Nøvling boringen, og at afsnittet fra $365 \mathrm{~m}$ og nedefter må henregnes hertil. Det skal dog bemærkes, at der ikke i foraminifermaterialet er fundet elementer, som kan støtte denne tolkning. Den mørke lerbjergart, som især præger prøven $1290^{\prime}-1320^{\prime}$, kan tænkes at stamme fra afsnittet 374-378 m eller fra et afsnit lige under 384 m, hvor GR-værdierne synes øgede. (»Lag distance « 40' lagt til sidstnævnte dybde svarer til en prøvedybde på $\left.1300^{\prime}\right)$.

Teglstensrød ler optræder i prøven $1350^{\prime}-1380^{\prime}$, men først i den følgende prøve findes top af zonen med Globigerina ex $g r$. triloculinoides (bl.a. G. patagonica TODD \& KNIKER), som er knyttet til det typiske Røsnæs ler. 
Grænsen mellem overgangslagene og Røsnæs leret må antagelig placeres ved ca. $408 \mathrm{~m}$ (1380' minus »lag distance « 40').

Røsnæs leret er formentlig kun nogle få meter mægtigt, idet top af ler med vulkansk aske også falder inden for prøveintervallet $1380^{\prime}-1410^{\prime}$. Mod forventning synes tilstedeværelsen af vulkanske askelag ikke at give sig udslag i særlig høje GR-værdier. Både Røsnæs ler og ler med vulkansk aske må antages at ligge i den nedre del af GR-afsnittet 384-417 m.

Under 417 m er GR-værdierne lave, og afsnittet $417-427 \mathrm{~m}$ må formodes at indeholde få (»negativ askeserie«?) eller ingen askelag. I prøven 1410'-1440', der med en indregnet »lag distance « på 40' skulle repræsentere det nævnte afsnit, spores ingen lithologisk ændring i forhold til den overliggende prøve, hvorfor tilstedeværelsen af fede lerbjergarter må antages på trods af de lave GR-værdier.

Der er en mulighed for, at afsnittet $417-427 \mathrm{~m}$ bør medregnes til paleocæn i stedet for som her til eocæn. Prøven $1440^{\prime}-1470^{\prime}$, der er behandlet i I. BANG's efterfølgende afsnit, må klart henføres til paleocæn på grundlag af lithologi og foraminiferer. Omslaget er modsvaret af en brat stigning på GR-kurven ved $427 \mathrm{~m}$, idet den tilsvarende prøvedybde med indregnet »lag distance« er 1441'.

Den foranstående gennemgang af eocæn afsnittet i Nøvling nr. 1 kan opsummeres med følgende inddelingsforslag:

312-317 (evt. 327) m: Søvind mergel.

317 (evt. 327)-352 m: Overgangslag mellem Lillebælt ler og Søvind mergel (i typisk udformning).

352-365 m: $\quad$ Lillebælt ler.

365-ca. $408 \mathrm{~m}$ : Overgangslag mellem Røsnæs ler og Lillebælt ler (i typisk udformning).

Ca. 408-417 m: $\quad$ Røsnæs ler (få meter) og ler med vulkansk aske.

417-427 m: $\quad$ Formation ant. bestående af fede lerbjergarter (paleocæn?).

ENGLISH SUMMARY

EOCENE IN NØVLING NO. 1

An Eocene series, extending from $312 \mathrm{~m}$ to $427 \mathrm{~m}$ (below Kelly Bushing), consists of stickly marls and clays, with beds of volcanic ash in the lower part. The series is represented by 14 ditch samples from the interval $1020^{\prime}-1440^{\prime}$.

The foraminiferal content was analysed in three separate fractions of the washed residuals: fraction $1(0.1 \mathrm{~mm}-0.25 \mathrm{~mm})$, fraction $2(0.25 \mathrm{~mm}-0.50 \mathrm{~mm})$, and fraction $3(0.50 \mathrm{~mm}-$ $1.00 \mathrm{~mm}$ ). The results of the countings are registered in the table. Some of the species are considered to be derived from beds younger than the Eocene. The numbers of these individuals are put down in brackets.

The sample $1020^{\prime}-1050^{\prime}$ consists of two components. A grey, slightly silty clay is probably the source of species like Textularia cf. sagittula, Bulimina elongata, Angulogerina ex gr. gracilis, Nonion affine, Valvulineria sp. sp., Ceratobulimina contraria, and Asterigerina gürichi. This clay belongs to the Upper Oligocene above $312 \mathrm{~m}$ (see the article by F. NY- 
HUUS KRISToffersen, p. 67). The other component of the sample $1020^{\prime}-1050^{\prime}$ is a whitish marl, incorporated as small patches and streaks in the clay. Undoubtedly, the Eocene foraminifera of the sample originate from this marl.

Observations from the Viborg No. 1 core hole and from East Jutland (DINESEN 1972) form a basis for a stratigraphic evaluation of the Eocene section in Nøvling No. 1. When the radioactivity logs and the lag distance $\left(40^{\prime}\right.$ estimated to be more reliable than the $80^{\prime}$ calculated at 1098', shown in figure 3) are compared with the data on lithology and foraminifera (see figure 15), a subdivision as follows may be suggested:

312-317 (or 327) m: Søvind Marl.

Lithology: Marl, whitish to light brownish grey (subordinately light reddish brown).

Characteristic foram.: Globigerapsis cf. index.

317 (or 327)-352 m: Transition beds from Lillebælt Clay to Søvind Marl.

Lithology: Marl, light brownish grey and light reddish brown.

Characteristic foram.: Pseudohastigerina wilcoxensis.

Remarks: The top of $P$. wilcoxensis is found in the sample 1080'1110'. 1080' minus lag distance $40^{\prime}$ corresponds to $317 \mathrm{~m}$. It is possibly a consequence of a large contamination from the $G$. cf. index zone above that only few specimens of $P$. wilcoxensis were recorded.

352-365 m: $\quad$ Lillebælt Clay,

Lithology: Clay, grey to greenish grey.

Characteristic foram.: Pseudohastigerina wilcoxensis (as above).

365-ca. $408 \mathrm{~m}$ : Transition beds from Røsnæs Clay to Lillebælt Clay.

Lithology: Clay, grey to greenish grey, subordinately dark, and downwards - reddish brown to brick red.

Characteristic foram.: ?

Remarks: The content of foraminifera may be very low in the transition beds. It is very likely that the specimens recorded in the samples $1170^{\prime}-1380^{\prime}$ to a great extent are derived from the zones above.

Ca. 408-417 m: Røsnæs Clay and Clay with Tuff.

Lithology: Clay, reddish brown to brick red; Clay, dark grey, pyritic, and volcanic ash.

Characteristic foram.: Globigerina ex gr. triloculinoides (in the Røsnæs Clay).

Remarks: No change is indicated on the gamma ray log at $408 \mathrm{~m}$, and the beds of tuff, occurring in the same sample $\left(1380^{\prime}-1410^{\prime}\right)$ as the Røsnæs Clay, do not imply higher values on the GR log. The estimated depth for the top of the Røsnæs Clay is $1380^{\prime}$ minus $40^{\prime}(=408 \mathrm{~m})$.

417-427 m: $\quad$ Formation of clay (?).

Remarks: The gamma ray values are much lower than they are just above $417 \mathrm{~m}$. It is possible that the interval should be referred to the Paleocene rather than to the Eocene.

\section{LITTERATUR}

Dinesen, A., 1972: Foraminiferselskaber fra de jyske eocæne formationer. - Dansk geol. Foren., Årsskrift for 1971, p. 70., København. 


\section{PALEOCÆN I NØVLING NR. 1 (427-640 M) \\ af}

\section{Inger Bang}

Hertil tavle $1-2$

Undersøgelsen omfatter intervallet mellem den vulkanske askeserie og maastrichtien 424-643 m. På grund af boremetoden er en nøjagtig afgrænsning opad umulig, og den er her foretaget på rent biostratigrafiske indicier, idet prøven $1440^{\prime}-1470$ ' (lag time kor.: 424-439 m) indeholder de første paleocæne foraminiferer. Et udsving på gammastrålekurven ved $418 \mathrm{~m}$ kan vise toppen af selandien men også en lithologisk grænse indenfor denne. Også grænsen danienmaastrichtien er biostratigrafisk bestemt, idet prøven 2160'-2190' (lag time korrigeret: $2080^{\prime}-2110^{\prime}(634-643 \mathrm{~m})$ ), indeholder de første senone foraminiferer (se yderligere artiklen af E. STENESTAD).

\section{LITHOLOGI}

Følgende lithologiske beskrivelse er foretaget på borestedet af OLAF MicheLSEN:

$1410^{\prime}-1500^{\prime}$ (430-457 m) Ler, fedt, grønt-gråsort, kalkfrit.

$1500^{\prime}-1560^{\prime}$ (457-465 m) Ler, ret fedt, mørkegråt, kalkfrit, samt siltsten, grå, hård, kalkholdig.

1560'-1680' (465-512 m) Ler, ret fedt, grønliggråt, kalkholdigt og siltsten, grå, hård, kalkholdig.

$1680^{\prime}-1740^{\prime}$ (512-530 m) Ler, stærkt finsandet, gråt, stærkt kalkholdigt, hård. 1740'-1800' (530-549 m) Kalksandsten, finkornet, lysegrå, hård.

1800'-1980' (549-604 m) Kalksten, ret hård, grålig-hvid samt mørk og lys gråbrun flint, enkelte bryozoer.

1980'-2250' (604-686 m) Kalksten, meget hård, tæt, grålighvid - hvid, ofte forkislet. Lys gråbrun flint findes, tiltager i mængde i den nederste del af serien.

På grundlag af tørrede prøver har F. NyHUUS KRISTOFFERSEN beskrevet den samme lagserie:

$1380^{\prime}-1440^{\prime}$ (421-439 m) Overvejende ler, rødbrunt, meget fedt, kalkholdigt, med lag af tuf, mørk grå, kalkfri. 
$1440^{\prime}-1770^{\prime}$ (439-539 m) Ler, grønliggråt, siltet, kalkholdigt, ofte som lersten, ret blødt. I den øvre del af intervallet $1440^{\prime}-1530^{\prime}$ (457-466 m) dominerer en lersten, grønliggrå, fed, temmelig let i tør tilstand, virker klæbrig, sandsynligvis på grund af stor porøsitet, kalkfri - meget svagt kalkholdig.

1770'-3600' (540-1097 m) Slamkalk, gullig hvid og grålighvid, let hærdnet. I intervallet $1770^{\prime}-1950^{\prime}$ (540-594 m) er den hyppigt kraftigere hærdnet uden dog at være særlig hård, siltet og mere gullig. I samme interval optræder en del bryozoer. I intervallet $1770^{\prime}-2520^{\prime}(540-668 \mathrm{~m})$ en del flint, tæt, gråbrun. I hele intervallet forekommer kraftigere hærdnede partier.

\section{MATERIALE}

Undersøgelsen omfatter 25 prøver (intervallet 1440'-2190') idet dog også prøverne derover er undersøgt for eventuelle paleocæne foraminiferer. Da samtlige prøver fra danien intervallet er domineret af lerarter fra tertiær, er der udpillet cuttings of danskekalken, som er slæmmet for sig og undersøgt. Den lithologiske beskrivelse er suppleret med undersøgelse af bjergarterne i de slæmmede prøver, især af hensyn til fastlæggelsen af den ikke særligt markerede grænse mellem selandien og danien. Den falder indenfor intervallet $1830^{\prime}-1860^{\prime}$, idet denne prøve indeholder en hvid kalksten med en typisk øvre danien fauna foruden en grå kalksten (»grønsandskalk«). Lag time korrigeret er dybden for prøven $1770^{\prime}-1810^{\prime}$ (540-552 m), og en ændring på gamma ray kurven omkring 545-550 m synes at betegne toppen af danskekalk formationen. Det kan bemærkes, at i den del af prøverne, som er slæmmet til biostratigrafisk undersøgelse, er ingen bryozoer konstateret.

\section{Selandien}

BIOSTRATIGRAFI

I prøven $1440^{\prime}-1470$ ' (439-448 m) optræder enkelte repræsentanter for en Kertemindemergel fauna, som bliver rigere nedefter: »Pseudovalvulineria« parvula (TEn DAm), Bulimina midwayensis Cushman \& PARKer, Ammodiscus sp., Spiroplectammina sp., Melonis nobilis (Brotzen), Pulsiphonina elegans Brotzen. Fra omkring 1650” (488 m) afløses den af »Gamborg-faunaen « (tavle 1-2), som er domineret af planktoniske foraminiferer, næsten udelukkende Globigerina danica, og ellers indeholder »Christellaria« sp., Bulimina thanethiensis HAYNES, B. midwayensis CUSHMAN \& PARKer, Quadrimorphina halli (JENnINGs), Allomorphina sp., Osangularia lens BROTZEN.

6* 


\section{Danien}

Toppen af danskekalk formationen indeholder relativt mange planktoniske foraminiferer, hvorfor det her er muligt at foretage en zonering.

Prøverne 1830'-1860' (558-567 m) og 1860'-1890' (567-576 m) kan henføres til den øverste zone i danien: Globigerina danica - Subbotina triloculinoides zonen (»Odense-faunaen «).

Dernæst følger med prøverne 1890'-1920' og 1920'-1950' Subbotina triloculinoides zonen (»Klintholm-faunaen«) og fra prøverne 1950'-1980' (594$603 \mathrm{~m}$ ) S. triloculinoides-Globoconusa daubergensis zonen (Rapport over boringerne på Storebælt, 1963 (upubl.) samt BANG 1969, henholdsvis zone IV, III og II).

Under 2010' (613 m) er kun fundet enkelte foraminiferer, sandsynligvis på grund af hærdningen af kalken. Det kan således ikke afgøres om hele danienserien er repræsenteret.

Sammenligner man med den nordfor liggende dybdeboring Vejrum nr. 4 (DGU arkiv nr. 64.236) hvor samtlige foraminiferzoner er til stede og hvis mægtighed udgør ca. $170 \mathrm{~m}$, kan man konstatere en reduktion, men det kan ikke afgøres, om man i Nøvling nr. 1 mangler en del af nedre danien, eller forklaringen er, at lagene kiler ud ind mod Ringkøbing-Fyn højderyggen.

\section{KONKLUSION}

- $418 \mathrm{~m}$ : kalkfrit ler, eocæn-paleocæn.

$418 \mathrm{~m}$-ca. $525 \mathrm{~m}$ : Kertemindeler, kalkfrit-kalkholdigt, selandien.

ca. $525 \mathrm{~m}$-ca. $550 \mathrm{~m}$ : kalksiltsten, foroven leret, selandien.

ca. $550 \mathrm{~m}-640 \mathrm{~m}$ : kalksten, danien.

$640 \mathrm{~m}-\quad$ kalksten, maastrichtien.

ENGLISH SUMMARY

PALEOCENE IN NØVLING NO. 1

The Selandian-Danian (Paleocene) interval is delimited, on the basis of foraminifera, from $1440^{\prime}(424 \mathrm{~m})$ to the sample $2160^{\prime}-2190^{\prime}(634-643 \mathrm{~m})$, which contains the first Maastrichtian foraminifera.

\section{LITHOLOGY}

The lithology has been described as follows (by O. Michelsen and F. Nyhuus KristofFERSEN):

1410'-1680' Clay, sticky, green to dark grey, upper part non-calcareous, below about 1560 ' calcareous, with alternating beds of siltstone, grey, calcareous.

$1680^{\prime}-1740^{\prime}$ Clay, silty, light grey, calcareous.

1740 '-1800' Siltstone, light grey, highly calcareous.

$1800^{\prime}-1980^{\prime}$ Limestone, grey to greyish white, with dark and light greyish-brown chert, a few bryozoans. 
$1980^{\prime}-2250^{\prime}$ Limestone, indurated, greyish white to white, often silicified, with light greyish-brown chert.

The boundary between the Selandian and Danian is not very well pronounced, but may be placed within $1830^{\prime}-1860^{\prime}$, as the sample from this interval contains cuttings of a white limestone with a typical upper Danian foraminiferal assemblage. From the gamma ray $\log$ the top of the Danian limestone is placed at about $545-550 \mathrm{~m}$ and the top of the siltand limestone at about $525 \mathrm{~m}$.

\section{Selandian}

\section{BIOSTRATIGRAPHY}

From the sample $1440^{\prime}-1470^{\prime}(424-439 \mathrm{~m})$ downwards a fauna occurs which is characteristic for the Kerteminde Clay: »Pseudovalvulineria« parvula (TEN DAM), Bulimina midwayensis Cushman \& PARKer, Ammodiscus sp., Spiroplectammina sp., Melonis nobilis (Brotzen), Pulsiphonina elegans Brotzen. From about 1650' (488 m) down it is succeeded by an assemblage (pl. 1-2) dominated by planktonic foraminifera, mostly Globigerina danica BANG, and contains in addition 》Cristellaria « sp., Bulimina thanetiensis HAYNES, B. midwayensis Cushman, Quadrimorphina halli (JENnINGs), Allomorphina sp., and Osangularia lens BROTZEN.

\section{Danian}

The upper part of the Danian limestone has been zoned as follows on the basis of the planktonic foraminifera:

1830'-1890' Globigerina danica-Subbotina triloculinoides Zone.

1890 '-1950' S. triloculinoides Zone ("Klintholm-assemblage") overlying the S. triloculinoides-Globoconusa daubjergensis Zone (BANG 1969).

Below 2010' only scarce, badly preserved foraminifera have been found on account of the induration of the limestone.

\section{CONCLUSION}

- 418 m: non-calcareous clay, Eocene-Paleocene.

$418 \mathrm{~m}$-ca. $525 \mathrm{~m}$ : Kerteminde Clay, non-calcareous to calcareous, Selandian. ca. $525 \mathrm{~m}$-ca. $550 \mathrm{~m}$ : siltstone and limestone, clayey in upper part, Selandian.

ca. $550 \mathrm{~m}-640 \mathrm{~m}$ : limestone, Danian.

$640 \mathrm{~m}-\quad$ limestone, Maastrichtian.

\section{LITTERATUR}

BANG, INGER, 1969. Planktonic Foraminifera and Biostratigraphy of the Type Danian. Proc. 1. Inter. Conf. Microfos., Geneva 1967, Vol. I, pp. 58-65, Leiden.

Brotzen, F., 1948. The Swedish Paleocene and its Foraminiferal Fauna. - Sver. Geol. Unders., Ser. C, Nr. 493, Stockholm. 


\section{ØVRE KRIDT I NØVLING NR. 1 \\ (640-1329 M)}

af

\section{Erik Stenestad}

Til rådighed for undersøgelsen har der været ca. 95 skylleprøver, udtaget i intervallet $2160^{\prime}-4360^{\prime}$ under kelly bushing (KB). Foraminiferundersøgelsen har omfattet samtlige disse prøver.

\section{LITHOLOGI}

D.G.U.'s geolog på borestedet, Olaf Michelsen, gav den første, foreløbige beskrivelse af den øvre kretaciske lagserie. Denne beskrivelse er suppleret med FinN NyHUUS KRISTOFFERSEN's iagttagelser ved en senere gennemgang af materialet i D.G.U.'s laboratorier. Endelig har ERIK STENESTAD i forbindelse med gennemgangen af foraminiferfaunaerne i de 31 prøver i intervallet $3930^{\prime}$ $4360^{\prime}$ undersøgt cuttingsfordelingen i fraktionen $\frac{1}{2}-1 \mathrm{~mm}$. (Se fig. 16).

Cuttingsundersøgelsen, der er kvalitativ, skal her kort refereres:

Følgende bjergartstyper er iagttaget i intervallet 3930'-4360'.

Type A: KALKSTEN, hvid-grålighvid, meget finkornet, med enkelte grovere calcitkorn og fossilfragmenter.

Type B: MERGEL, grønliggrå, glimmerholdig, stedvis fint lagdelt.

Type C: MERGELSTEN, fint lagdelt med grå, kalkfri, glimmerrige lag vekslende med hvidlige, kalkrige lag med skalfragmenter.

Type D: FLINT, hvidgrå.

Type E: PYRIT.

Type F: KALKSTEN, lys grålig, meget finkornet, med sortgrå LER-slirer.

Type G: KALKSTEN, grålighvid-gullighvid, meget finkornet, tæt, hård-meget hård.

Type H: KALKSTEN, gullighvid, ret finkornet, med enkelte glauconitkorn, stærkt præget af Inoceram-prismer.

Type I: KALKSTEN, lys gulliggrå, med grønligt eller rødligt skær, ret finkornet, med lidt silt, glimmer og glauconit.

Type K: LERSTEN, sort-gråsort, ret fed, kalkholdig, med lidt glimmer, glauconit og finsand samt kalklegemer (bl.a. foraminiferer).

Type L: KALKSTEN, grå og grønliggrå, ret finkornet, glauconit-, glimmer- og siltholdig.

Type M: MERGELSTEN, grå og grønliggrå, glauconit-, glimmer- og siltholdig.

Type N: MERGELSTEN, sortgrå, med hvidlige, uregelmæssige, skalrige, kalkslirer. Foraminiferskallerne er orienteret parallelt med lagdelingen.

Som ovenfor anført, er cuttingsundersøgelsen udført kvalitativt, fordi prøvernes cuttingssammensætning kun i begrænset omfang kan benyttes ved en vurdering af hvilke bjerg- 
CUMTINGSFORDELING I FRAKTIONEN $1-\frac{1}{2} \mathrm{~mm}$ :

\begin{tabular}{|c|c|c|c|c|c|c|c|c|c|c|c|c|c|c|}
\hline $\begin{array}{c}\text { Dybde } \\
\text { under } \\
\text { K. } \mathrm{B} \text {. }\end{array}$ & $\begin{array}{l}\text { Bje } \\
A\end{array}$ & $\begin{array}{l}\text { erg: } \\
B\end{array}$ & C & sty & E & F & G & $\mathrm{H}$ & I & K & L & $M$ & $1 \mathrm{~N}$ & Vurdering: \\
\hline 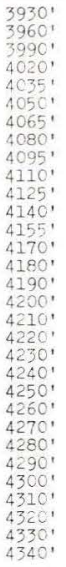 & $\begin{array}{l}+ \\
+ \\
+ \\
+ \\
+ \\
+ \\
+ \\
+ \\
+ \\
+ \\
+ \\
+ \\
+ \\
+ \\
+ \\
+ \\
+ \\
+ \\
+ \\
+ \\
+ \\
+\end{array}$ & $\begin{array}{l}+ \\
+ \\
+ \\
+ \\
+ \\
+ \\
+ \\
+ \\
+ \\
+ \\
+ \\
+ \\
+ \\
+ \\
+ \\
+ \\
+ \\
+\end{array}$ & $\begin{array}{l} \\
+ \\
+ \\
+ \\
+ \\
+ \\
+ \\
+ \\
+ \\
+ \\
+ \\
+ \\
+ \\
+ \\
+ \\
+ \\
+ \\
+ \\
+\end{array}$ & $\begin{array}{l}+ \\
+ \\
+ \\
+ \\
+ \\
+ \\
+\end{array}$ & $\begin{array}{l}+ \\
+\end{array}$ & $\begin{array}{l}+ \\
+\end{array}$ & $\begin{array}{l} \\
+ \\
+ \\
+ \\
+ \\
+ \\
+ \\
+ \\
+ \\
+ \\
+ \\
+ \\
+ \\
+ \\
+ \\
+ \\
+\end{array}$ & $\begin{array}{l}+ \\
+ \\
+ \\
+ \\
+ \\
+ \\
+ \\
+ \\
+ \\
+ \\
+ \\
+\end{array}$ & $\begin{array}{l}+ \\
+ \\
+ \\
+ \\
+\end{array}$ & $\begin{array}{l}+ \\
+ \\
+\end{array}$ & $\begin{array}{l}+ \\
+ \\
+\end{array}$ & + & $\begin{array}{l}+ \\
+\end{array}$ & $\begin{array}{l}\text { Type A veksl. med (?) tynde lag af type B. } \\
\text { Type C introduceres. } \\
\text { Type G introduceres. } \\
\text { Type G med underordnede lag af type } N \text {, evt. } \\
\text { tillige repræaentation af overligende } \\
\text { typer. } \\
\text { Type I, evt. med lag af type } G \text {. } \\
\text { Et tyndt lag type } \mathrm{K} \text {, underlejret af type } \mathbb{N} \\
\text { med underordnede lag af type } \mathrm{I} \text {. }\end{array}$ \\
\hline
\end{tabular}

Fig. 16

arter, der dominerer i et givet interval. Mindre solide bjergarter kan evt. opmales helt i boremudderet og tynde lag opdages antagelig slet ikke, fordi de »fortyndes « så stærkt i boremudderet, at chancen for at finde dem i prøverne er minimal. Hertil kommer de forstyrrelser, cavings fra højere niveauer kan medføre, især hvor det drejer sig om mindre karakteristiske bjergarter. Endelig består der den risiko, at en »original « cuttingstype fejlagtigt betragtes som cavings, fordi den ikke kan skelnes fra en type i den overliggende lagserie. Det er derfor klart, at det lithologiske profil under alle omstændigheder beror på et skøn og må tages med forbehold. Det fortæller ikke, hvordan lagserien ser ud i detaljer, men omtaler hovedtrækkene af nogle karakteristiske bjergartstypers fordeling.

\section{Det lithologiske profil}

Dybdetal i engelske fod er de på prøverne benyttede, hvorimod dybdetal i meter er korrigerede $\mathrm{i}$ henhold til lagtime kurven og i muligt omfang tillige ved hjælp af Schlumberger diagrammerne, gamma ray (gamma stråling), ITT (interval transit time, lydhastighed) og resistivity (modstand).

Bjergartstyper, som ikke er påvist i den overliggende lagserie, er kursiveret.

2160'-2970' (640-884 m) Kalksten, hvid, blød, meget finkornet, (skrivekridt). 2340'-2550' med flint, lys brunliggrå (fra daniet?). Kalkstenens øvre grænse findes ved 2040' $(614 \mathrm{~m})$. Lagserien mellem denne dybde og den biostratigrafiske maastrichtien/danien grænse ved $640 \mathrm{~m}$ formodes at være danisk slamkalk.

2970'-3510' (884-1061 m) Kalksten, hvid til grålighvid, meget finkornet, ret blod, med underordnede lag af lysegrå mergel. 
3510'-3990' (1061-1216 m) Kalksten, hvid til grålighvid, meget finkornet, ret blød til ret hård, med

Mergel, grønliggrå, glimmerholdig, stedvis fint lagdelt.

Sporadisk optræder flint, hvidgrå og pyrit samt kalksten, gullighvid, ret finkornet, med enkelte glauconitkorn og stærkt præget af skalrester fra inoceramer.

3990'-4050' (1216-1228 m) Kalksten, hvid til grålighvid, meget finkornet, ret blød til ret hård, med

Mergel, grønliggrå, glimmerholdig, stedvis fint lagdelt.

Mergelsten, fint lagdelt, med grå, kalkfri, glimmerrige lag, vekslende med hvidlige, kalkrige lag med skalfragmenter.

$4050^{\prime}-4155^{\prime}$ (1228-1257 m) Kalksten, hvid til grålighvid, meget finkornet, ret blød til ret hård,

Mergel, grønliggrå, glimmerholdig,

Mergelsten, fint lagdelt med grå og hvidlige lag, Kalksten, grålighvid til gullighvid, meget finkornet, hård til meget hård.

?4155'-4300' (1257-1291 m) Kalksten, grålighvid til gullighvid, meget finkornet, tæt, hård til meget hård med underordnede lag af

Mergelsten, sortgrå, med hvidlige kalkslirer, samt antagelig med lag af blødere kalksten med og uden lerede slirer, mergel af grå og grønlig farve, flint og finkornet kalksten som ovenfor.

4300'-4320' (1291-1316 m) Kalksten, lys gulliggrå, med grønligt eller rødligt skar, ret finkornet, hård, med lidt silt, glimmer og glauconit, muligvis vekslende med kalksten og mergel som ovenfor.

ved $4320^{\prime}(1316 \mathrm{~m}) \quad$ Lersten, sort til gråsort, ret fed, kalkholdig, fint lagdelt.

4320'-4350' (1316-1329 m) Mergelsten, grå og grønliggrå, glauconit-, glimmerog siltholdig, med underordnede lag af

Kalksten, grå og grønliggrå, ret finkornet, glauconit-, glimmer-og siltholdig.

Et forkortet boreprofil er vist fig. 17.

Det lithologiske profil fra øvre kridt afsnittet i Nøvling er sammenlignet med tilsvarende profiler fra andre boringer i området. I hovedtrækkene er profilerne meget lig hinanden, selv om detaljerne er noget afvigende. Det er i det hele 


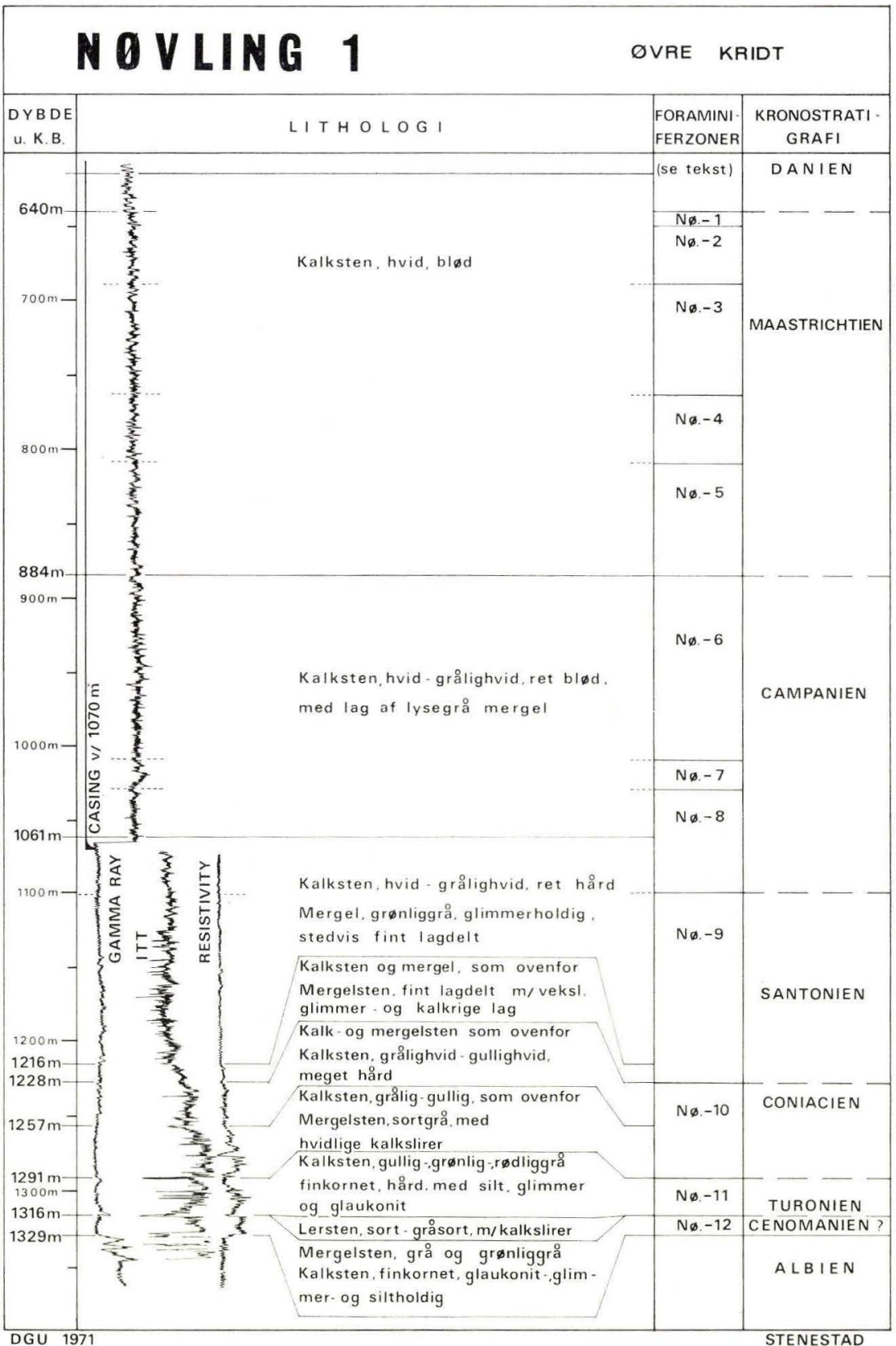

Fig. 17. 
taget svært at få et pålideligt billede af detajlerne, dels fordi boreprøvernes kvalitet, som ovenfor anført, sjældent tillader en præcis tolkning, dels fordi boringerne er bearbejdet i meget forskellig grad. En oversigt over hovedtrækkene af det danske bassins udvikling i øvre kridt er givet i STENESTAD (1972).

\section{BIOSTRATIGRAFI}

Øvre kridt serien i Nøvling nr. 1 er udelukkende boret ved skylleboring. Foraminiferernes bevaringstilstand er generelt god; men de enkelte prøvers indhold af foraminiferer fra overliggende lag er ret betydelig, hvad der vanskeliggør den nøjagtige fastlæggelse af arternes vertikale udbredelse. Heraf følger, at også den biostratigrafiske inddeling nødvendigvis bliver noget usikker. Det har dog været muligt at inddele serien i et antal foraminiferzoner, der nedenfor omtales i den rækkefølge, hvori de træffes under borearbejdet, d.v.s. fra top til bund af profilet. Zonenummereringen refererer specielt til den foreliggende boring, hvad der er markeret med »Nø《 foran zonenummeret. Dybdetallene i meter er korrigerede.

\section{Nø.-1. Pseudotextularia elegans zonen. 2160'-2190' (640-650 m).}

Prøverne over $2130^{\prime}$ indeholder kun enkelte fragmenter af øvre kridt foraminiferer.

Prøven 2130'-2160' indeholder talrige eksemplarer af Heterohelix striata (EHRENBERG 1840) samt enkelteksemplarer af Bolivinoides ? peterssoni BROTZEN 1945 (juv.), Gavelinella pertusa (MARSSON 1878), Eouvigerina cretae (EHRENBERG 1854), Praebulimina laevis (BeIssel 1891) og Praebulimina sp.

Prøven 2160'-2190' indeholder en typisk øvre maastrichtien foraminiferfauna med bl.a. Stensioeina esnehensis NAKADY 1950, Pseudotextularia elegans (RzEHAK 1891), Bolivinoides draco (MARsson 1878) ssp. draco Hilt. \& Koch 1950. Neoflabellina aff. numismalis (WEDEKIND 1940) samt Praebulimina laevis og Gavelinella pertusa.

Grænsen mellem danien og øvre kridt skal søges i prøverne 2130'-2190'. Måske findes grænsen nederst i intervallet $2130^{\prime}-2160^{\prime}$, eller måske er de senone former i dette interval blot omlejrede. Mest sandsynligt er det, at der er tale om omlejret materiale og at grænsen findes i prøven $2160^{\prime}-2190^{\prime}$. Denne prøves dybdeangivelser er i henhold til lag time beregningerne ca. $80^{\prime}$ for store. Dette betyder, at den søgte grænse antagelig ligger i intervallet $2080^{\prime}-2110^{\prime}$. Ved $2100^{\prime}(640 \mathrm{~m})$ findes en lille, men tydelig ændring i gamma ray kurven (se fig. 17). Det foreslås, at grænsen mellem danien og øvre kridt placeres ved denne dybde.

Nø.-2. Pseudouvigerina rugosa zonen. 2190'-2340' (650-689 m).

Prøverne øverst i dette afsnit indeholder Pseudouvigerina rugosa BROTZEN 1945 
sammen med andre karakteristiske øvre maastrichtien arter som Stensioeina esnehensis, Bolivinoides peterssoni, Pseudouvigerina cristata (MARSSON 1878) og Heterohelix dentata STENESTAD 1968. Desuden forekommer »Bolivina incrassata Reuss 1851, Bolivinoides draco (MARsson 1878) ssp. draco HiLt. \& KocH 1950, Praebulimina laevis (BEISSEL 1891), Eouvigerina cretae (EHRENBERG 1854) og Osangularia »lens « HofKer 1957, NON Brotzen. Heterohelix striata er meget talrigt tilstede.

De korrigerede dybder fremkommer ved reduktion med $80^{\prime}$ lag distance.

Nø.-3. Loxostoma selmaensis zonen. 2340'-2580' (689-762 m).

Denne zones øvre grænse er sat ved højeste forekomst af Bolivina incrassata Reuss 1851 ssp. gigantea Wicher 1949. I prøverne findes bl.a. en del eksemplarer af Loxostoma selmaensis (CUSHMAN 1931), der er hyppigst i den mellemste del af maastrichtienet, sammen med en lang række foraminiferarter, der er almindelige i den mellemste og øverste del af maastrichtien. Det er ikke lykkedes at påvise zonen med Pseudouvigerina cimbrica Troelsen MS. 1945 i dette afsnit, hvad der er forståeligt, da arten er sjælden, og da prøverne er meget stærkt forurenede af teriært materiale.

Zonen Nø.-3's øvre grænse svarer nogenlunde til grænsen mellem øvre og nedre maastrichtien. De korrigerede dybder fremkommer ved reduktion med $80^{\prime}$ lag distance.

Nø.-4. Bolivina incrassata gigantea zonen. 2580'-2730' (762-808 m).

Afsnittet karakteriseres af den fra Aalborgområdet velkendte »crassa«-form af B. incrassata gigantea. Desuden forekommer Heterohelix glabrans (CUSHMAN 1938) og en række andre former, der viser, at zonen svarer ret nøje til TROELSEN's zone III alpha.

Zonen med Bolivinoides decorata (JONES) ssp. laevigata MARIE 1941 er muligvis tilstede i den nederste del af intervallet, men har ikke kunnet påvises med sikkerhed.

Nø.-5. Bolivinoides draco miliaris zonen. 2730'-2970' (808-884 m).

Den øvre grænse er sat ved højeste forekomst af Bolivinoides draco (MARSSON 1878) ssp. miliaris HiLt. \& Косн 1950, der i det nederste maastrichtien afløses af B.d. ssp. draco, som findes i resten af maastrichtienet. Prøvedybden er reduceret med 80' lag distance. I faunaen indgår bl.a. talrige eksemplarer af Rugoglobigerina rugosa (PLUMmER 1926). Stensioeina pommerana BROTZEN 1936 er almindelig. Et enkelt eksemplar af Neoflabellina cf. rugosa (D’OrBIGNY 1840) er fundet midt i intervallet. 
Nø.-6. Pyramidina pseudospinulosa zonen. 2970'-3360' (884-1008 m).

Lige som i Rønde boringen er zonens øvre grænse lagt ved den højeste massive optræden af Pyramidina pseudospinulosa (TROELSEN MS. 1945), der iøvrigt kendes fra santonien til nedre maastrichtien. Heterohelix robusta STENESTAD 1968 er påvist i de øverste prøver i denne zone, hvad der støtter opfattelsen af, at zonens øvre grænse er nær ved eller sammenfaldende med grænsen mellem øre campanien og nedre maastrichtien. Grænsen er sammenfaldende med en lithologisk grænse, der imidlertid ikke markerer sig særlig tydeligt i gamma ray kurven. Zonens øvre grænse er reduceret med 70' lag distance til 2900', svarende til $884 \mathrm{~m}$.

Nø.-7. Globorotalites multiseptus zonen. 3360'-3420' (1008-1027 m).

Zonen kendes bl.a. fra Rønde boringen, hvor den lige som i Nøvling boringen indeholder en fauna, der må anses for at være af øvre campanien alder. Foruden Globorotalites multiseptus (BROTZEN 1936) indgår Pyramidina pseudospinulosa og Stensioeina pommerana.

Den øvre grænse er korrigeret med 53' lag distance.

Nø.-8. Stensioeina labyrinthica zonen. 3420'-3660' (1027-1102 m).

Der har ikke som i Rønde boringen kunnet udskilles en selvstændig zone med Stensioeina pommerana mellem denne og den overliggende zone. Prøverne indeholder Stensioeina labyrinthica CusHMAN \& DORSEY 1940 og Stensioeina exsculpta (Reuss 1860). Globorotalites multiseptus er hyppig og Gavelinella clementiana (D'ORBIGNY 1840) er almindelig. Den øvre grænse er korrigeret med 51' lag distance. Alderen anses for at være campanien.

Nø.-9. Stensioeina exsculpta zonen. $3660^{\prime}-4035^{\prime}(1102-1228 \mathrm{~m})$.

Den øvre grænse er lagt ved højeste forekomst af Stensioeina exsculpta (Reuss 1860) ssp. gracilis BROTZEN 1945. Der er ingen støtte at hente i lithologien. Den øvre grænse er korrigeret med 44' lag distance. Faunaen omfatter Stensioeina exsculpta (Reuss) ssp. granulata (Olbertz 1942), Globotruncana lapparenti Brotzen ssp. indet. og Cibicides eriksdalensis Brotzen 1936 samt en del agglutinerende arter af slægterne Arenobulimina og Gaudryina. Desuden indgår en rigelig repræsentation af Globotruncana- og Stensioeina-arter fra den overliggende zone.

Zonens alder er sandsynligvis santonien.

Nø.-10. Stensioeina praeexsculpta zonen. $4035^{\prime}-4270^{\prime}(1228-1291 \mathrm{~m})$.

Den øvre grænse er lagt ved højeste forekomst af Stensioeina praeexsculpta 
(Keller 1935). Prøvedybden $4035^{\prime}$ er reduceret med $15^{\prime}$ lag distance til 4020', der svarer til $1225 \mathrm{~m}$. Der findes imidlertid en veldefineret lithologisk grænse ved $1228 \mathrm{~m}$ og det anses for rimeligt at lægge også foraminiferzonens grænse ved denne dybde. Desuden forekommer Pyramidina cushmani (Brotzen 1936), Gavelinella costata Brotzen 1942 ssp. emscheriana (HofKer 1957), Globotruncana lapparenti Brotzen ssp. lapparenti Brotzen emend. Bolli 1945 og Marssonella turris (D'ORBIGNY 1840).

I den nedre del af zonen spiller en sortgrå mergelsten med hvidlige, kalkrige slirer en vis rolle. Faunabilledet præges af de agglutinerende, benthoniske (bundlevende) slægter som Ataxophragmium, Bathysiphon, Gaudryina, Spiroplectammina og Verneuilina, m. fl. Desuden indgår rester af fisk og andre dyregrupper, bl. a. knogler, tænder, hudtænder og coproliter samt inoceram-prismer.

Zonen henføres lige som i Rønde boringen til coniacien. Det er et interessant træk, at man i emscher i Heide træffer tilsvarende, mørkegrå, fint lagdelte lermergellag, der er rige på fiskerester (GRIPP 1964).

Nø.-11. Globotruncana marginata zonen. 4270'-4320' (1291-1316 m).

Afsnittet indeholder en beskeden fauna med Globotruncana marginata (Reuss 1845), Anomalinoides globosa Brotzen 1945, Gavelinella cenomanica (BROTZEN 1945), Praeglobotruncana stefani Gandolfi 1942, Marssonella trochus (D'ORBIGNY 1840) og Spiroplectinata jaekeli (FrANKe 1925). Den øvre grænse er lagt ved højeste forekomst af Globotruncana marginata. Prøvedybden er korrigeret med en skønsmæssig lag distance på 20' til 1295 m og - med henvisning til prøvernes ringe kvalitet - hævet til den lithologiske grænse ved $1291 \mathrm{~m}$.

Nederst i afsnittet optræder en sortgrå lersten, der klart giver sig til kende på Schlumberger kurverne. Den indeholder kun nogle få, ubestemmelige foraminiferfragmenter. Den overliggende kalksten kan med nogen sandsynlighed henføres til nedre turonien på grund af tilstedeværelsen af Praeglobotruncana stefani og Gavelinella cenomanica, og den underliggende serie er, som nedenfor omtalt, med nogen usikkerhed henført til cenomanien.

I Rønde er et tilsvarende mergelstenslag henført til nedre turon. I Heide og Lüneburg i Tyskland kender man tilsvarende lermergellag (»sapropel «-lag) i nedre turon. Andre steder i det dansk-tyske bassin, for eksempel i Skåne og på Bornholm, har man vidnesbyrd om en kraftig regression omkring dette tidspunkt (Stenestad 1972, p. 66).

Den overliggende zone, Nø.-10, er lithologisk udformet på en måde, der minder om den lithologiske udformning af zone Nø.-11, idet man i begge zoner har en nedre del, der præges af sortgrå mergelstenslag, overlejret af en kalkstens- og mergelstensserie. Jeg opfatter de nedre, stærkt lermergelprægede led som vidnesbyrd om regressioner, der har ramt hele bassinet (jf. ovenstående), hvad der har været medbestemmende for min placering af grænserne mellem zonerne Nø.-10, Nø.-11 og Nø.-12. 
Nø.-12. ? Gavinella cenomanica zonen. 4320'-4360' (1316-1329 m).

Såvel den nedre som den øvre grænse er fastlagt ved hjælp af lithologien. Prøverne indeholder kun forholdsvis få bjergartsfragmenter, som med rimelighed kan antages at tilhøre dette interval. Dette skyldes antagelig lagenes ringe mægtighed og svage hærdningsgrad. Indholdet af foraminiferer er næppe ret stort i dette afsnit, idet der ikke er set skaller eller skalfragmenter siddende in situ i de enkelte cuttings. Der er fundet nogle få eksemplarer af Gavelinella cenomanica (BROTZEN 1945), Anomalinoides globosa BROTZEN 1945, Marssonella trochus (D'ORBIGNy 1840) og Tappanina eouvigeriniformis (Keller 1935). Bevaringstilstanden er meget dårlig og det er trods et omfattende sorterearbejde, specielt i dette afsnit, ikke lykkedes at nå til en sikker datering. Det vigtigste holdepunkt i dette afsnit er de geofysiske logs: gamma ray, resistivity og ITT (interval-transit-time, en art sonic log), der nøje afgrænser afsnittet og samtidig muliggør en lithologisk korrelation med bl.a. Rønde boringens tilsvarende afsnit. I Rønde er det dateret til cenomanien og foraminiferindholdet og den stratigrafiske placering tyder på, at alderen også i Nøvling kan være cenomanien. Det kan dog ikke udelukkes, at serien helt eller delvis kan tilhøre turonet.

\section{KONKLUSION}

Gennemgangen af prøvematerialet fra Nøvling nr. 1 synes at vise, at lagserien omfatter alle 6 øvre kridt etager. Den samlede lagtykkelse $(689 \mathrm{~m})$ er af nogenlunde samme størrelsesorden som i de øvrige dybdeboringer, Vemb, Vinding, Horsens, Glamsbjerg, Ringe, Ullerslev og Slagelse, i strøget sydvest for den centrale del af øvre kridt bassinet. (Se STENESTAD 1972, fig. 2).

På grundlag af de lithologiske og biostratigrafiske resultater foreslås flg. kronostratigrafiske inddeling:

\begin{tabular}{cl} 
Dybde i m under KB: & \multicolumn{1}{c}{ Etage } \\
$640-884$ & Maastrichtien \\
$884-1102$ & Campanien \\
$1102-1228$ & Santonien \\
$1228-1291$ & Coniacien \\
$1291-1316$ & Turonien \\
$1316-1329$ & ? Cenomanien
\end{tabular}

En skematisk oversigt over etager og foraminiferzoner med angivelse af de skønnede lagmægtigheder i boringerne Rønde nr. 1 og Nøvling nr. 1 er vist fig. 18 . 


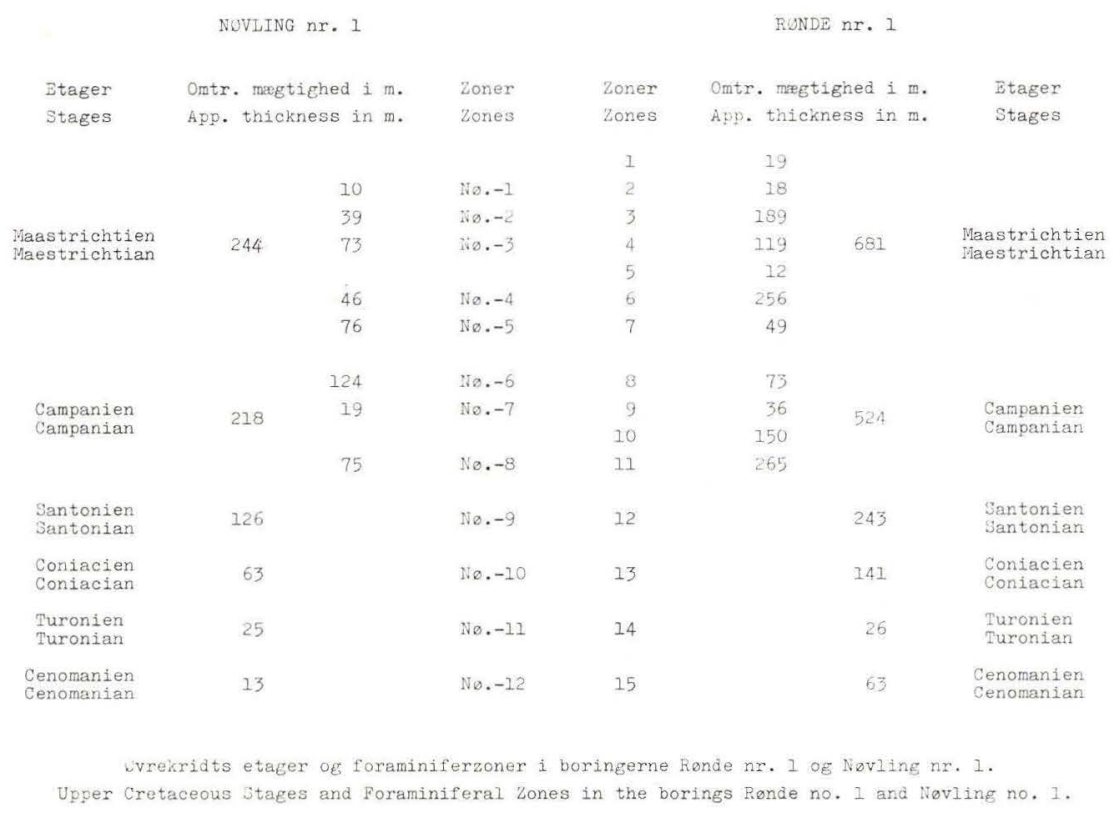

Fig. 18

ENGLISH SUMMARY

UPPER CRETACEOUS IN NØVLING NO. 1

Based on about 95 ditch samples from the interval $2160^{\prime}-4360^{\prime}$ below KB, the Upper Cretaceous sequence is described as follows:

$2160^{\prime}-2970^{\prime}(640-884 \mathrm{~m}) \quad$ Limestone, white, soft, very fine-grained (chalk). 2340'-2550' w/ flint, light brownish grey (from the Danian?). Top of limestone at 2040' $(614 \mathrm{~m})$. The sequence between $2040^{\prime}$ and $2160^{\prime}$ is presumably Danian ooze limestone.

$2970^{\prime}-3510^{\prime}(884-1061 \mathrm{~m})$ Limestone, white to greyish white, very fine-grained, rather soft, w/ marly intercalations.

3510'-3990' (1061-1216 m) Limestone, white to greyish white, very fine-grained, rather soft to rather hard, w/ marlstone, greenish grey, micaceous, in places finely laminated. Sporadically w/ whitish grey flint, pyrite, and limestone, yellowish white, rather fine-grained, slightly glauconitic, rich in Inoceramus remains.

$3990^{\prime}-4050^{\prime}$ (1216-1228 m) Limestone, white to greyish white, very fine-grained, rather soft to rather hard, w/ marl, greenish grey, micaceous, in places finely laminated. Marlstone, finely laminated, alternatingly whitish, calcareous, w/ shell remains and grey, noncalcareous, micaceous.

$4050^{\prime}-4155^{\prime}$ (1228-1257 m) Limestone, white to greyish white, very fine-grained, rather soft to rather hard, marl, greenish grey, micaceous, marlstone, finely laminated grey, and whitish. Limestone, greyish white to yellowish white, very fine-grained, hard to very hard. 
?4155'-4300' (1257-1291 m) Limestone, greyish white to yellowish white, very fine-grained, dense, hard to very hard, w/ intercalations of marlstone, blackish grey, w/ calcite-filled fissure veins and probably w/ layers of softer limestone with or without marly intercalations, w/ grey and greenish grey marl, flint, and fine-grained limestone as above.

4300'-4320' (1291-1316 m) Limestone, light yellowish grey, w/ greenish or reddish tinge, rather fine-grained, hard, w/ some silt, mica, and glauconite, and possibly alternating with limestone and marl as above.

at $4320^{\prime}(1316 \mathrm{~m}) \quad$ Claystone, black to greyish black, calcareous, finely laminated.

$4320^{\prime}-4350^{\prime}$ (1316-1329 m) Marlstone, grey and greenish grey, glauconitic, micaceous and silty, w/ subordinate beds of limestone, grey and greenish grey, rather fine-grained, glauconitic, micaceous, and silty.

The lower part of this sequence has been examined by means of a qualitative cuttingsanalysis, see above fig. 16 .

The Schlumberger logs are shown in text-figure 17.

The lithology of the Upper Cretaceous in Nøvling No. 1 has been compared with that of other borings in this area. The main features are very uniform, but the details may be rather divergent. Most samples are ditch samples, which do not allow very precise interpretation of the details. Furthermore, the borings have not been studied and described in a uniform way.

A brief review of the lithology of the Upper Cretaceous in the Danish Embayment is given in Stenestad (1972) (Two paleogeographic maps. In Danish).

\section{BIOSTRATIGRAPHY}

The samples are all ditch samples, which means that it may be rather difficult to establish the exact range of the species. So, the biostratigraphical zonation may be a little questionable. It has been possible to delimit 12 local, informal foraminiferal zones. The zonal numbers refer particularly to the boring in question indicated by " $\mathrm{N} \varnothing$ " in front of the figures. All indications of depth are below Kelly Bushing. Depths quoted in meters are corrected in accordance with the time-lag calculations and the geophysical logs.

Nø.-1. The Pseudotextularia elegans zone. 2160'-2190' (640-650 m).

Bolivinoides draco (MARsson 1878) ssp. draco Hilt. \& Koch 1950, B. ? peterssoni Brotzen 1945 (juv.), Eouvigerina cretae (EHRENBERG 1854), Gavelinella pertusa (MARsson 1878), Heterohelix striata (EHRENBERG 1840), Neoflabellina aff. numismalis (WEDEKIND 1940), Prebulimina laevis (BeIssel 1891), Pseudotextularia elegans (RzeHAK 1891), Stensioeina esnehensis NAKADY 1950.

Nø.-2. The Pseudouvigerina rugosa zone. 2190'-2340' (650-689 m).

"Bolivina" incrassata Reuss 1851, Bolivinoides draco draco, B. peterssoni, Eouvigerina cretae, Heterohelix dentata STENESTAd 1968, H. striata, Osangularia "lens" Hofker 1957, non Brotzen, Praebulimina laevis, Pseudouvigerina cristata (MARsson 1878), P. rugosa Brotzen 1945, Stensioeina esnehensis.

Nø.-3. The Loxostoma selmaensis zone. $2340^{\prime}-2580^{\prime}$ (689-762 m).

The upper limit of this zone has been placed at the top of the range-zone of "Bolivina" incrassata ReUss 1851 ssp. gigantea WICHER 1949. Loxostoma selmaensis (CUSHMAN 1931) and other species which are typical in the middle and upper part of the Maestrichtian are 
common in this interval. The top of zone Nø.-3 is believed to be close to the top of the Lower Maestrichtian. The zone with Pseudouvigerina cimbrica TroeLSEN MS 1945 has not been found.

Nø.-4. The "Bolivina" incrassata gigantea zone. 2580'-2730' (762-808 m).

This interval is characterized by the so-called "crassa"-form of B. incrassata gigantea, which is well known from the Aalborg area in Jutland, Denmark. Heterohelix glabrans (CUSHMAN 1938) and other species indicate that the Nø-4-zone is more or less identical with the zone III alpha of TROELSEN (1937).

Nø.-5. The Bolivinoides draco miliaris zone. 2730'-2970' (808-884).

The upper limit of this zone has been placed at the topmost presence of Bolivinoides draco (Marsson 1878) ssp. miliaris Hilt. \& Koch 1950, which in the lowermost Maestrichtian is succeeded by $B$. draco draco. Rugoglobigerina rugosa (Plummer 1926) and Stensioeina pommerana BROTZEN 1936 are common. One specimen of Neoflabellina cf. rugosa (D'ORBIGNY 1840) has been recognized.

Nø.-6. The Pyramidina pseudospinulosa zone. 2970'-3360' (884-1008 m).

The upper limit has been placed at the last (highest) point of abundant presence of Pyramidina pseudospinulosa (TROELSEN MS 1945), ranging from Santonian to Lower Maestrichtian. The presence of Heterohelix robusta STENESTAD 1968 supports the assumption of this point being close to the boundary between Upper Campanian and Lower Maestrichtian. The top of the zone Nø.-6 coincides with a change in lithology (see above).

Nø.-7. The Globorotalites multiseptus zone. 3360'-3420' (1008-1027 m).

Globorotalites multiseptus (BRotZen 1936), Pyramidina pseudospinulosa, and Stensioeina pommerana seem to indicate an Upper Campanian age.

Nø.-8. The Stensioeina labyrinthica zone. 3420'-3660' (1027-1102 m).

The samples contain Stensioeina labyrinthica Cushman \& DoRsey 1940 and S. exsculpta (REuss 1860). Globorotalites multiseptus is abundant and Gavelinella clementiana (D'ORBIGNY 1840) is common. The age is believed to be Lower Campanian.

Nø.-9. The Stensioeina exsculpta zone. 3660'-4035' (1102-1228 m).

The upper limit has been placed at the top of the occurrence of $S$. exsculpta (REuss 1860) ssp. gracilis BROTZEN 1945. No support was found in the lithology. Cibicides eriksdalensis Brotzen 1936, Globotruncana lapparenti Brotzen ssp. indet, Stensioeina exsculpta (Reuss) ssp. granulata (OLbertz 1942), and some species of the genera Arenobulimina and Gaudryina together with species of Globotruncana and Stensioeina from the above zone make up the foraminiferal content of the samples. The age is presumably Santonian.

Nø.-10. The Stensioeina praeexsculpta zone. 4035'-4270' (1228-1291 m).

The upper limit of this zone was placed at the top of the occurrence of Stensioeina praeexsculpta (KELLER 1935). The depth of the sample, 4035', was reduced with a 15' lag distance to $4020^{\prime}$ or $1225 \mathrm{~m}$. Subsequently it was lowered to the marked lithological boundary at $1228 \mathrm{~m}$. The foraminiferal fauna includes Gavelinella costata BROTZEN 1942, ssp. emscheriana (HofKer 1957), Globotruncana lapparenti BROTZEN 1936 ssp. lapparenti Brotzen emend. Bolli 1945, Pyramidina cushmani (Brotzen 1936), and Marssonella turris (D'ORBIGNY 1840).

In the lower part of the interval a blackish grey marlstone with whitish calcite-filled fissure veins is of some importance. The fauna is characterized by agglutinating benthonic genera like Ataxophragmium, Bathysiphon, Gaudryina, Spiroplectammina, Verneuilina and others. Besides, fish remains, bone remains, teeth, scales, coproliths, and shell fragments of Inoceramus are found. 
The interval is referred to the Coniacian. Similar dark grey, finely laminated marlstones with fish remains are well-known from the Emscherian of Heide, Germany (GRIPP 1964).

Nø.-11. The Globotruncana marginata zone. 4270'-4320' (1291-1316 m).

The samples contain a small fauna with Anomalinoides globosa Brotzen 1945, Gavelinella cenomanica (BROTZEN 1945), Globotruncana marginata (Reuss 1845), Marssonella trochus (D'ORbigny 1840), Praeglobotruncana stefani Gandolfi 1942, and Spiroplectinata jaekeli (FRANke 1925). The upper boundary has been placed at the top of the occurrence of Globotruncana marginata. The depth is corrected by means of lag-time calculations to $1295 \mathrm{~m}$ and, pleading the poor quality of the samples in this interval, raised to the lithological boundary at $1291 \mathrm{~m}$. In the lowermost part of the sequence a blackish grey, calcareous, finely laminated claystone was found (see logs, text-figure 17), which holds but a few fragments of foraminifera. The superjacent limestone is most likely Lower Turonian, since Praeglobotruncana stefani and Gavelinella cenomanica are present. The subjacent sequence may be Cenomanian (or Lower Turonian). In the boring Rønde No. 1 an equivalent claystone was referred to Lower Turonian. In Heide and Lüneburg in Germany similar marls ("sapropel") are known from the Lower Turonian. Elsewhere in the Danish-German basin (e.g. Scania and Bornholm) evidence of a marked regression at about this time is found (STENESTAD 1972, p. 66). The author believes that the marly basal parts of the zones Nø.-10 and Nø.-11 are due to extensive regressions, more or less affecting the entire basin. This point of view has been a contributory cause to the choice made of the position of the boundaries between the zones Nø.-10, Nø.-11, and Nø.-12.

Nø.-12 ?The Gavelinella cenomanica zone. 4320'-4360' (1316-1329 m).

The limits of this interval are placed on the basis of the lithology; the Schlumberger logs especially have been useful. The ditch samples held only a modest amount of cuttings which could be assumed to originate from the depths indicated. The number of foraminifera was very low and no fossils have been observed in situ in the cuttings. In the boring Rønde No. 1, the comparable part of the Upper Cretaceous sequence was referred to the Cenomanian. In the boring here described, the stratigraphical position and the few specimens of foraminifera found suggest that the age may be Cenomanian, but it is possible that the sequence or part of it could belong to the Turonian.

\section{STRATIGRAPHICAL CONCLUSIONS}

It seems likely that the boring Nøvling No. 1 includes all of the Upper Cretaceous stages. The total thickness, $689 \mathrm{~m}$, is approximately of the same magnitude as in the other deep tests, Vemb, Vinding, Horsens, Glamsbjerg, Ringe, Ullerslev, and Slagelse, in the region south-west of the central part of the Danish Upper Cretaceous Basin, as shown in textfigure 2 in STENESTAD (1972).

\section{CHRONOSTRATIGRAPHIC EVALUATION}

$\begin{array}{cl}\text { Depth below Kelly Bushing }(\mathrm{m}): & \text { Stage: } \\ 640-884 & \text { Maestrichtian } \\ 884-1102 & \text { Campanian } \\ 1102-1228 & \text { Santonian } \\ 1228-1291 & \text { Coniacian } \\ 1291-1316 & \text { Turonian } \\ 1316-1329 & \text { ? Cenomanian }\end{array}$

The Upper Cretaceous stages and foraminiferal zones and their estimated thicknesses in the borings Rønde No. 1 and Nøvling No. 1 are shown in text-figure 18. 


\section{LITTERATUR}

BANDY, O. L., 1967. Cretaceous planktonic foraminiferal zonation. - Micropaleontology Vol. 13, No. 1, 1967, New York.

BARR, F. T., 1962. Upper Cretaceous planktonic foraminifera from the Isle of Wight, England. - Palaeontology, Vol. 4, Pt. 4, 1962, London.

Brotzen, F., 1936. Foraminiferen aus dem schwedischen, untersten Senon von Eriksdal in Schonen. - Sveriges Geol. Undersökning, ser. C. no. 396, Stockholm.

- 1940. Flintrännans och Trindelrännans Geologi (Öresund). - Sveriges Geol. Undersökning, ser. C. no. 435, Stockholm.

- 1942. Die Foraminiferengattung Gavelinella nov. gen. und die Systematik der Rotaliiformes. - Sveriges Geol. Undersökning, ser. C. no. 451, Stockholm.

- 1945. De geologiska resultaten från borrningarna vid Höllviken. Del I: Kritan. Sveriges Geol. Undersökning ser. C. no. 465, Stockholm.

Butt, A. A., 1966. Foraminifera of the type Turonian. - Micropaleontology, Vol. 12, No. 2, New York.

Cushman, J. A., 1938. Cretaceous Species of Guembelina and Related Genera. - Contr. Cush. Lab. Foram. Res. Vol. 14, pt. 1, Sharon, Mass.

Gripp, K., 1964. Erdgeschichte von Schleswig-Holstein. Karl Wachholtz Verlag, Neumünster.

Hiltermann, H. \& W. Koch, 1950. Taxonomie und Vertikalverbreitung vonBolivinoidesArten im Senon Nordwestdeutschlands. - Geol. Jb. Bd. 64, Hannover/Celle.

- 1962. Oberkreide des nördlichen Mitteleuropa. - In: Simon, W.: Leitfossilien der Mikropaläontologie, pp. 299-338, Berlin.

Hofker, J. sen., 1957. Foraminiferen der Oberkreide von Nordwestdeutschland und Holland. - Geol. Jb. Beiheft 27, Hannover.

- 1966. Maestrichtian, Danian and Paleocene Foraminifera. - Palaeontographica, Suppl. Bd. 10, Stuttgart.

Loeblich, A. R. \& H. TAppan, 1964. Foraminiferida. - In: Treatise on Invertebrate Paleontology, Pt. C, Protista 2, - The Geological Society of America/The University of Kansas Press.

MARIE, P., 1941. Les Foraminiferes de la Craie a Belemnitella mucronata de Bassin de Paris. - Mem. Mus. Nat. d'Hist. Nat. N. Sér. Tom. XII, Fasc. 1, marts 1941, Paris.

Pessagno, E. A. jr., 1967. Upper Cretaceous Planktonic Foraminifera from the Western Gulf Coastal Plain. - Palaeontographica Americana, Vol. V, No. 37, Ithaca, New York.

Stenestad, E., 1971. Øvre kridt i Rønde nr. 1. - In: Banke Rasmussen, L. et al.: Dybdeboringen Rønde nr. 1 på Djursland. Danm. geol. Unders. III rk. nr. 39, pp. 53-60, fig. 10 (summary in English), København.

- 1972. Træk af det danske bassins udvikling i øvre kridt. - Dansk Geol. Foren., Årsskrift for 1971, pp. 63-69, fig. 1-3, København.

Troelsen, J. C., 1937. Om den stratigrafiske Inddeling af Skrivekridtet i Danmark. Medd. Dansk Geol. Foren. Vol. 9, no. 2, København. 


\section{MARINT NEDRE KRIDT I NØVLING NR. 1 $(1329-(1483 \mathrm{M}))$ \\ af}

\section{Arne Buch}

Denne undersøgelse omfatter ialt 34 prøver fra intervallet $1329-1483 \mathrm{~m}$ under kelly bushing. (Alle dybdetal i dette afsnit er korrigerede for lag time, se tabel 1, p. 102). De øverste $70 \mathrm{~m}$ af lagserien indeholder en meget rig samling af foraminiferer. Der er påvist 247 nedre kretaciske arter, hvoraf 188 er benyttet til den biostratigrafiske inddeling af profilet. Dette store antal er opnået af et rigeligt udgangsmateriale med op til 500 eksemplarer udsorteret af enkeltprøverne. Det blev derved muligt i hver prøve at isolere nyintroducerede arter fra det store opsummerede fossilmateriale fra allerede gennemborede lag. I tabel 2, p. 103, er de enkelte arter opført i den rækkefølge, hvori de første gang er truffet i profilet under borets nedtrængen gennem lagserien.

\section{LITHOLOGI}

Den lithologiske beskrivelse af lagserien er foretaget af Olaf Michelsen:

1329-1422 m Lersten, ret fed, stærkt kalkholdig. Øverst i dette afsnit varierer farven som rødbrun, mørkebrun, gulligbrun og gråbrun, under 1343 m dominerer grå-gråsort, nederst i afsnittet sammen med brungrå. Under $1364 \mathrm{~m}$ forekommer lidt pyrit samt brune lerjernstenskonkretioner.

1422-1847 m Finsandsten, mellemkornet, lysegrå-grå, glauconitholdig, svagt kalkholdig. Nedefter mere finkornet og med kalcitårer.

1495-1629 m: Finsandstenen danner overgange til og afløses under dette interval af lersten, svagt finsandet - ret fed, gråsort med blåligt skær, svagt kalkholdig. Pyrit og lerjernstenskonkretioner er almindelige i hele afsnittet.

Til denne beskrivelse kan føjes følgende iagttagelser:

Det nedre kretaciske afsnit af boreprofilet markeres øverst af en tydelig lithologisk ændring. Fra en overlejrende hård, lysegrå kalksten med indslag af en finsandet mergel og en ret fed, sort til gråsort lersten, et sedimentkompleks, som ved hjælp af foraminiferer er dateret til øvre kridt, sker der ved $1329 \mathrm{~m}$ en brat ændring, og der træffes en ret fed, stærkt kalkholdig lersten af varierende farver. Ved hjælp af foraminiferer, der er farvet af det sediment, hvori de har 
været indlejret, er det muligt at fastslå alderen af de stærkt farvede lersten. I prøven 1330-1334 m fandtes rødfarvede eksemplarer af Glomospirella gaultina, Haplophragmoides nonioninoides, Lenticulina gaultina, Gavelinopsis berthelini, Gyroidina gracillima, Gavelinella intermedia, Hedbergella planispira. De rødfarvede lersten er således klart af albien alder, fordelt over zoner af mellem albien og af nedre albien alder. De gullige lersten er af tilsvarende alder. Dette indiceres af gultfarvede eksemplarer af Glomospira gordialis, Reophax minuta og Arenobulimina preslii, som ikke var repræsenteret blandt de rødfarvede. Desuden er der gultfarvede eksemplarer af arter, der også forekommer i røde sedimenter: Glomospirella gaultina, Lenticulina gaultina, Gavelinopsis cenomanica, Gavelinopsis berthelini og Gyroidina gracillima. Det ser således ud til at både de gule og de rødfarvede lersten er knyttet til mellem og nedre albien. Violette farver er truffet i foraminiferer af følgende arter: Glomospira gordialis, Glomospirella gaultina, Haplophragmoides nonioninoides, Astacolus sp., Lenticulina gaultina, Gavelinopsis berthelini, Gyroidina gracillima og Gavelinopsis intermedia. I den lithologiske beskrivelse er intet meddelt om sedimenter med violette nuancer. Det er derfor muligt, at indfarvningen i dette tilfælde har anden årsag.

Oversigt over inddelingen af nedre kridt i Nøvling 1.

\begin{tabular}{|c|c|c|}
\hline \multicolumn{3}{|l|}{ korrigeret dybde } \\
\hline $1329-1337 \mathrm{~m}$ & \multicolumn{2}{|c|}{ (?Mellem og) nedre albien } \\
\hline $1337-1342 \mathrm{~m}$ & \multicolumn{2}{|l|}{ Aptien } \\
\hline $1342-1348 \mathrm{~m}$ & \multicolumn{2}{|c|}{ Barrémien } \\
\hline $1348-1360 \mathrm{~m}$ & \multicolumn{2}{|c|}{ Øvre hauterivien } \\
\hline $1360-1371 \mathrm{~m}$ & Øvre & \multirow{2}{*}{ valanginien } \\
\hline $1371-1394 \mathrm{~m}$ & Mellem & \\
\hline $1394-(1483 \mathrm{~m})^{*}$ & \multicolumn{2}{|c|}{ Nedre kridt - jura } \\
\hline
\end{tabular}

* Denne undersøgelse når til 1483 m dybde. 
Tabel 1. Dybdekorrektioner i nedre kridt intervallet, Nøvling 1.

\begin{tabular}{|c|c|c|c|c|}
\hline $\begin{array}{c}\text { Prøve } \\
\text { nr. }\end{array}$ & $\begin{array}{l}\text { Ukorr. } \\
\text { dybde }\end{array}$ & $\begin{array}{c}\text { Beregnet } \\
\text { forsinkelse }\end{array}$ & $\begin{array}{l}\text { Korrek- } \\
\text { tion }\end{array}$ & $\begin{array}{c}\text { Korrigeret } \\
\text { dybde }\end{array}$ \\
\hline 1 & $4375^{\prime}$ & $33,6 \mathrm{~min}$. & $16^{\prime}$ & $4359^{\prime}=1329 \mathrm{~m}$ \\
\hline 2 & $4385^{\prime}$ & 33,8 & $22^{\prime}$ & $4363^{\prime}=1330 \mathrm{~m}$ \\
\hline 3 & $4395^{\prime}$ & 33,2 & $19^{\prime}$ & $4376^{\prime}=1334 \mathrm{~m}$ \\
\hline 4 & $4405^{\prime}$ & 33,9 & $19 \frac{1}{2}^{\prime}$ & $4385 \frac{1}{2}^{\prime}=1337 \mathrm{~m}$ \\
\hline 5 & $4415^{\prime}$ & 34 & $21 \frac{1}{2}^{\prime}$ & $4393 \frac{1}{2}^{\prime}=1339 \mathrm{~m}$ \\
\hline 6 & $4425^{\prime}$ & 33,2 & $22^{\prime}$ & $4403^{\prime}=1342 \mathrm{~m}$ \\
\hline 7 & $4435^{\prime}$ & 33,5 & $22 \frac{1}{2}^{\prime}$ & $4412 \frac{1}{2}^{\prime}=1345 \mathrm{~m}$ \\
\hline 8 & $4445^{\prime}$ & 33,8 & $22^{\prime}$ & $4423^{\prime}=1348 \mathrm{~m}$ \\
\hline 9 & $4455^{\prime}$ & 34,3 & $23 \frac{1}{2}^{\prime}$ & $4431 \frac{1}{2}^{\prime}=1351 \mathrm{~m}$ \\
\hline 10 & $4470^{\prime}$ & 34,8 & $33^{\prime}$ & $4437^{\prime}=1352 \mathrm{~m}$ \\
\hline 11 & $4485^{\prime}$ & 34,7 & $40 \frac{1}{2}^{\prime}$ & $4444 \frac{1}{2}^{\prime}=1355 \mathrm{~m}$ \\
\hline 12 & $4500^{\prime}$ & 34,8 & $47^{\prime}$ & $4453^{\prime}=1357 \mathrm{~m}$ \\
\hline 13 & $4515^{\prime}$ & 35 & $52 \frac{1}{2}^{\prime}$ & $4462 \frac{1}{2}^{\prime}=1360 \mathrm{~m}$ \\
\hline 14 & $4530^{\prime}$ & 35 & $50^{\prime}$ & $4480^{\prime}=1366 \mathrm{~m}$ \\
\hline 15 & $4545^{\prime}$ & 35,2 & $47^{\prime}$ & $4498^{\prime}=1371 \mathrm{~m}$ \\
\hline 16 & $4560^{\prime}$ & 35,1 & $38 \frac{1}{2}^{\prime}$ & $4521 \frac{1}{2}^{\prime}=1378 \mathrm{~m}$ \\
\hline 17 & $4575^{\prime}$ & 35 & $37^{\prime}$ & $4538^{\prime}=1383 \mathrm{~m}$ \\
\hline 18 & $4590^{\prime}$ & 35 & $44^{\prime}$ & $4546^{\prime}=1386 \mathrm{~m}$ \\
\hline 19 & $4605^{\prime}$ & 35 & $47 \frac{1}{2}^{\prime}$ & $4557 \frac{1}{2}^{\prime}=1389 \mathrm{~m}$ \\
\hline 20 & $4620^{\prime}$ & 35 & $50 \frac{1}{2}^{\prime}$ & $4569 \frac{1}{2}^{\prime}=1393 \mathrm{~m}$ \\
\hline 21 & $4635^{\prime}$ & 35,1 & $44 \frac{1}{2}^{\prime}$ & $4590 \frac{1}{2}^{\prime}=1399 \mathrm{~m}$ \\
\hline 22 & $4650^{\prime}$ & 35,5 & $54^{\prime}$ & $4596^{\prime}=1401 \mathrm{~m}$ \\
\hline 23 & $4665^{\prime}$ & 36,1 & $56^{\prime}$ & $4609^{\prime}=1405 \mathrm{~m}$ \\
\hline 24 & $4680^{\prime}$ & 36 & $52 \frac{1}{2}^{\prime}$ & $4627 \frac{1}{2}^{\prime}=1410 \mathrm{~m}$ \\
\hline 25 & $4695^{\prime}$ & 36,1 & $39 \frac{1}{2}^{\prime}$ & $4655 \frac{1}{2}^{\prime}=1419 \mathrm{~m}$ \\
\hline 26 & $4710^{\prime}$ & 36 & $37 \frac{1}{2}^{\prime}$ & $4672 \frac{1}{2}^{\prime}=1424 \mathrm{~m}$ \\
\hline 27 & $4725^{\prime}$ & 36,3 & $38 \frac{1}{2}^{\prime}$ & $4686 \frac{1}{2}^{\prime}=1428 \mathrm{~m}$ \\
\hline 28 & $4740^{\prime}$ & 36,2 & $48 \frac{1}{2}^{\prime}$ & $4691 \frac{1}{2}^{\prime}=1430 \mathrm{~m}$ \\
\hline 29 & $4755^{\prime}$ & 36,5 & $44 \frac{1}{2}^{\prime}$ & $4710 \frac{1}{2}^{\prime}=1436 \mathrm{~m}$ \\
\hline 30 & $4770^{\prime}$ & 36,4 & $53^{\prime}$ & $4717^{\prime}=1438 \mathrm{~m}$ \\
\hline 31 & $4800^{\prime}$ & 36,7 & $62^{\prime}$ & $4738^{\prime}=1444 \mathrm{~m}$ \\
\hline 32 & $4830^{\prime}$ & 37,9 & $52^{\prime}$ & $4778^{\prime}=1456 \mathrm{~m}$ \\
\hline 33 & $4860^{\prime}$ & 38,6 & $37^{\prime}$ & $4823^{\prime}=1470 \mathrm{~m}$ \\
\hline 34 & $4890^{\prime}$ & 41,2 & $26^{\prime}$ & $4864^{\prime}=1483 \mathrm{~m}$ \\
\hline
\end{tabular}


Tabel 2. Foraminiferarternes introduktionsfølge i det marine nedre kridt, Nøvling 1

Ved $1329 \mathrm{~m}$

Glomospira gordialis (JONES \& PARKER 1860)

Glomospirella gaultina (BERTHELIN 1880)

Lenticulina gaultina (BERTHELIN 1880)

Gavelinopsis cenomanica (BROTZEN 1945)

Hedbergella planispira (TAPPAN 1940)

Gyroidina gracillima (TEN DAM 1947)

Gavelinella intermedia (BERTHELIN 1880)

$1329-1330 \mathrm{~m}$

Gavelinopsis berthelini (KELLER 1935)

Hedbergella spp.

Lamarckina cf. lamplughi (SHERLOCK 1914)

1330-1334 m

Reophax minuta TAPPAN 1940

Haplophragmoides nonioninoides

(Reuss 1863)

Gaudryina dividens Grabert 1959

Arenobulimina cf. preslii (REuss 1846)

1334-1337 m

Ammobaculites reophacoides

BARTENSTEIN 1952

Verneuilinoides subfiliformis

BARTENSTEIN 1952

1337-1339 m

Haplophragmoides latidorsatus

(BORNEMANN 1855)

Ammobaculites parvisipira TEN DAM 1950

Spiroplectinata lata GRABERT 1959

Dorothia gradata (BERTHELIN 1880)

Eggerellina mariae TEN DAM, 1950

Astacolus schloenbachi (Reuss 1863)

Dentalina soluta Reuss 1851

Lenticulina muensteri (ROEMER 1839)

Lenticulina subalata (Reuss 1854)

Lenticulina subgaultina (BARTENSTEIN 1962)

Marginulinopsis robusta (REUss 1863)

Pseudonodosaria humilis (Roemer 1841)

Eoguttulina anglica

Cushman \& Ozawa 1930

Globulina prisca Reuss 1863

Pleurostomella obtusa BERTHELIN 1880

1339-1342 m

Lituotuba incerta FrANKE 1928

Cribrostomoides $\mathrm{sp}$.

Conorotalites aptiensis (BETTENSTAEDT 1952)
$1342-1345 \mathrm{~m}$

Rhizammina indivisa BRADY 1884

Reophax scorpiurus MONTFORT 1808

Gaudryina gradata BERTHELIN 1880

Dentalina distincta REUSs 1860

Lenticulina ouachensis wisselmanni (BETTENSTAEDT 1952)

Lenticulina schreiteri (EICHENBERG 1935)

Marginulinopsis gracilissima (REUss 1863)

Saracenaria spinosa (EICHENBERG 1935)

Vaginulina sp.

Conorotalites intercedens

(Bettenstaedt 1952)

Gavelinella barremiana BetTENSTAEdT 1952

1345-1348 m

Textularia foeda Reuss 1846

Trochammina inflata (MONTAGU 1808)

Gaudryinella sherlocki BetTENSTAEDT 1952

Marssonella subtrochus BARTENSTEIN 1962

Marginulinopsis bettenstaedti BARTENSTEIN \& BRAND 1951

Ramulina aculeata WRIGHT 1886

Epistomina caracolla caracolla

(RoEmer 1841)

Epistomina ornata (Roemer 1841)

$1348-1351 \mathrm{~m}$

Ammolagena clavata (JONES \& PARKER 1860)

Haplophragmium aequale (ROEMER 1841)

Nodosaria obscura Reuss 1846

Dentalina gracilis (D'ORBIGNY 1840)

Frondicularia concinna KосH 1851

Lagena apiculata Reuss 1850

Lagena apiculata emaciata Reuss 1863

Lenticulina crepidularis (ROEMER 1842)

Lenticulina cf. nodosa (Reuss 1863)

Lenticulina $c f$. sulcifera (REuss 1863)

Marginulina dispar Reuss 1846

Marginulinopsis striatocostata (REUSS 1863)

Vaginulina recta ReUss 1863

Ramulina globulifera BRADY 1879

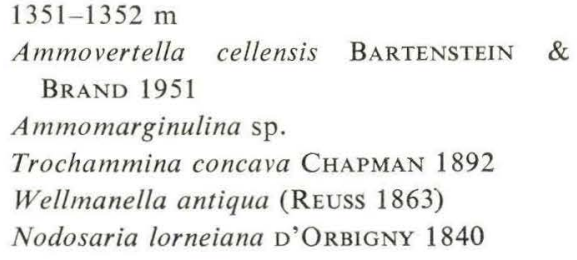

Nodosaria lorneiana D'ORBIGNY 1840 
Nodosaria zippei Reuss 1845

Dentalina communis (D'ORBIGNY 1826)

Dentalina siliqua Reuss 1863

Lagena hauteriviana hauteriviana (BARTENSTEIN \& BRAND 1951)

Lagena oxystoma Reuss 1863

Lenticulina eichenbergi BARTENSTEIN \& BRAND 1951

Lenticulina guttata (TEN DAM 1946)

Lenticulina ouachensis ouachensis (SIGAL 1952)

Marginulina inaequalis REUSs 1860

Marginulinopsis trunculata (BERTHELIN 1880)

Saracenaria sp.

Vaginulina harpa ROEMER 1841

Vaginulinopsis humilis humilis (REUss 1863)

Conorotalites bartensteini

(Bettenstaedt 1952)

1352-1355 m

Wellmanella praeantiqus (BARTENSTEIN \& BRAND 1949)

Astacolus grata (Reuss 1863)

Dentalina deflexa Reuss 1863

Frondicularia rehburgensis BARTENSTEIN \& BRAND 1951

Saracenaria bronnii (ROEMER 1841)

Vaginulina kochii ROEMER 1841

Vaginulina truncata REUss 1863

Conorotalites sigmoicosta (TEN DAM 1948)

Conorboides hofkeri

(BARTENSTEIN \& BRAND 1951)

1355-1357 m

Haplophragmium agglutinans

D'ORBIGNY 1846

Verneuilinoides neocomiensis

(MJATliuk 1939)

Marginulina pyramidalis (KoCH 1851)

Marginulinopsis breyeri (ZEDLER 1961)

Vaginulina procera ALBERs 1952

Vaginulinopsis humilis praecursoria BARTENSTEIN \& BRAND 1951

1357-1360 m

Reophax cf. pilulifera BRADY 1884

Verneuilinoides subfiliformis

BARTENSTEIN 1952

Verneuilinoides inaequalis BARTENSTEIN \& BRAND 1951

Citharina orthonota (REUSS 1863)

Dentalina linearis (ROEMER 1841)
Dentalina megapolitana Reuss 1855

Lingulina sp.

Epistomina caracolla anterior BARTENSTEIN \& BRAND 1951

1360-1366 m

Marssonella kummi ZedLer 1961

Nodosaria regularis TERQUEM 1862

Nodosaria sceptrum sceptrum REUSs 1863

Citharina pseudostriatula BARTENSTEIN \& BRAND 1951

Lenticulina saxonica saxonica BARTENSTEIN \& BRAND 1951

1366-1371 m

Reophax lageniformis CHAPMAN 1892

Tritaxia tricarinata Reuss 1845

Citharina acuminata (REuss 1863)

Saracenaria frankei TEN DAM 1946

Lingulina semiornata Reuss 1863

Tristix acutangulus (REUss 1863)

Buliminella loeblichi

BARTENSTEIN \& BRAND 1951

1371-1378 m

Ammobaculites agglutinans

(D'ORBIGNY 1846)

Ammobaculites eocretaceus BARTENSTEIN \& BRAND 1951

Haplophragmium glomeratum BRADY 1878

Haplophragmium inconstans gracile BARTENSTEIN \& BRAND 1951

Haplophragmium inconstans inconstans BARTENSTEIN \& BRAND 1951

Textularia agglutinans D'ORBIGNY 1839

Bigenerina clavellata

Loeblich \& TAPpan 1946

Trochammina globigeriniforme (PARKER \& JONES 1865)

Trochammina nana (BRADY 1881)

Astacolus aspera (CHAPMAN 1893)

Marginulinopsis oldenburgensis BARTENSTEIN \& BRAND 1951

Lingulina serrata TAPPAN 1940

Conorboides valendisensis (BARTENSTEIN \& BRAND 1951)

1378-1383 m

Ammobaculites sp. 1

Bartenstein \& Brand 1951

Trochammina depressa Lozo 1944

Nodobacularia nodulosa (CHAPMAN 1891) 
Astacolus calliopsis (Reuss 1863)

Vaginulinopsis reticulosa (TEN DAM 1946)

1383-1386 m

Nodosaria procera FrANKE 1936

Frondicularia hastata ROEMER 1842

Marginulina spinata TERQUEM 1858

Pseudonodosaria sexcostata

(BORNEMANN 1854)

Vaginulina costulata ROEMER 1842

Vaginulina eurynota Reuss 1863

1386-1389 m

Tolypammina sp.

Reophax minutissima

BARTENSTEIN \& BRAND 1951

Ammobaculites irregulariformis BARTENSTEIN \& BRAND 1951

Gaudryina vetutissima BARTENSTEIN \& BRAND 1951

Gaudryinella hannoverana BARTENSTEIN \& BRAND 1951

Lagena hauteriviana cylindracea BARTENSTEIN \& BRAND 1951

Marginulinopsis densicostata

THALMANN 1937

1389-1393 m

Ammolagena sp.

Citharina rudocostata BARTENSTEIN \&

BrAND 1951

Marginulina linearis ReUss 1863

Marginulinopsis parkeri (REUss 1863)

Vaginulina duestensis

BARTENSTEIN \& BRAND 1951

Vaginulinopsis matutina (D'ORBIGNY 1849)

Bullopora depressa (CHAPMAN 1891)

1393-1399 m

Ingen nytilkomne arter

1399-1401 m

Vaginulinopsis denudata (REuss 1863)

Webbinella rugosa TEN DAM 1950

1401-1405 m

Haplophragmium inconstans erectum BARTENSTEIN \& BRAND 1951

Tritaxia pyramidata Reuss 1863
1405-1410 m

Astacolus planiuscula (Reuss 1863)

Astacolus pulchella (Reuss 1863)

Astacolus varians recta (FrankE 1936)

Lenticulina ouachensis multicella BARTENSTEIN \& BRAND 1957

Saracenaria italica Defrance 1824

Vaginulinopsis linearis (Reuss 1863)

Falsoguttulina wolburgi BARTENSTEIN \& BRAND 1949

1410-1419 m

Citharina discors (KocH 1851)

1419-1424 m

Haplophragmoides globigeriniforme (PARKER \& JONES 1865)

Verneuilina variabilis BRADY 1884

Gaudryina rugosa D'ORBIGNY 1840

Valvulina concava PARKER \& JONES 1865

Nubeculinella sp.

Patellina subcretacea Cushman \& AleXanDER 1930

1424-1428 m

Ammobaculites subcretaceus CUSHMAN \& Alexander 1930

Citharina sparsicostata (REUss 1863)

$1428-1430 \mathrm{~m}$

Reophax nodulosa BRADY 1879

Haplophragmoides cushmani LoEBLICH \& TAPPAN 1946

Marginulina folkestoniensis CHAPMAN 1893

Webbinella cf. subhemisphaerica FRANKE

$1430-1436 \mathrm{~m}$

Cyclammina sp.

Marginulinopsis comma (ROEMER 1841)

Lingulina loreyi (BERTHELIN 1880)

Epistomina tenuicostata BARTENSTEIN \& BRAND 1951

$1436-1438 \mathrm{~m}$

Vaginulina riedeli

BARTENSTEIN \& BRAND 1951

1438-1483 m

Ingen nyintroducerede arter

I tabel 2 er foraminiferarterne opsummeret i den rækkefølge, hvori de er truffet i prøverne, dvs. at artens navn nævnes i det prøveinterval, hvor den første gang er til stede regnet fra oven. 


\section{BIOSTRATIGRAFI}

Mellem? og nedre albien 1329-1337 m

Ved $1329 \mathrm{~m}$ fandtes i den øverste prøve, en cirkulationsprøve hvor boret har roteret i nogen tid i samme dybde, af ialt 300 udsorterede foraminiferer kun 19 eksemplarer, der fordelte sig over 8 arter med en stratigrafisk udbredelse, som inkluderer albien. De øvrige 281 er af øvre kretacisk alder og repræsenterer materiale fra det overliggende boreinterval. Tilstedeværelsen af Hedbergella planispira daterer prøven til mellem eller nedre albien. De tre følgende prøver, der tilsammen dækker intervallet 1329-1337 m, er på tilsvarende måde domineret af nedfald fra øvre kridt. De nyintroducerede arter viser imidlertid, at afsnittet er af nedre albien alder. Af disse bør enkelte arter, der er særligt vigtige for dateringen, omtales nærmere: Lamarckina lamplughi kendes fra allerøverste aptien og nedre albien med hyppigste optræden i de to nederste zoner af nedre albien. Gaudryina dividens forekommer i størst antal i øvre aptien, medens den er sparsomt til stede i hele nedre albien. Ammobaculites reophacoides findes fra nedre barrémien til mellem albien (begge inklusive), talrigest til stede i mellem og nedre barrémien. Verneuilinoides subfiliformis er kendt fra øvre hauterivien til nederste zone af mellem albien. Den er talrigest repræsenteret i største delen af barrémien og nederst $\mathrm{i}$ aptien. I aptienets øvre afsnit er den sjældnere, medens den er talrigere i de nederste to zoner af nedre albien. I øvre delen af nedre albien og i nederste zone af mellem albien optræder den sporadisk.

\section{Aptien 1337-1342 m}

I dette interval, der indeholder to prøver, er en mere præcis datering vanskelig. Haplophragmoides latidorsatus er med 15 eksemplarer den talrigst repræsenterede art. Denne agglutinerende forms vertikale udbredelse er ifølge litteraturen fra mellemste mellem barrémien til nederste nedre aptien. To eksemplarer, der med nogen usikkerhed er bestemt til Lenticulina cf. muensteri og Lenticulina cf. subalata, giver antydning af, at lag af endnu ældre afsnit er indarbejdet i materialet. Lenticulina muensteri forekommer fra nedre hauterivien til mellemste zone af nedre barrémien, med enkelte eksemplarer i mellemste mellem barrémien. Lenticulina subalata har en tilsvarende udbredelse, men den kan desuden findes mere spredt indtil øvre del af nedre albien. Conorotalites aptiensis har en vertikal udbredelse, der er begrænset fra øverste zone af øvre barrémien til nederste zone af nedre albien, talrigest omkring grænsen øvre barrémien-nedre aptien. På det foreliggende grundlag er intervallet $1337-1342 \mathrm{~m}$ bedømt til at være stratigrafisk placeret $\mathrm{i}$ aptien.

\section{Barrémien 1342-1348 m}

De følgende $6 \mathrm{~m}$ indeholdt en kombination af nytilkomne arter, ialt 23, der 
sandsynliggør, at lag af øvre, mellem og nedre barrémien er truffet i dette afsnit. Især tilstedeværelsen af Lenticulina ouachensis wisselmanni, Conorotalites intercedens og Gavelinella barrémiana i stort antal viser, at barrémien er repræsenteret. Intervallets nederste $3 \mathrm{~m}$ indeholdt enkelteksemplarer af Epistomina caracolla caracolla og Epistomina ornata, to arter der er karakteristiske i øvre valanginien, hele hauterivien og som mere spredt er til stede i nedre barrémien. Dette forhold indicerer muligvis, at grænsen til øvre hauterivien netop er passeret. Øverst $\mathrm{i}$ intervallet introduceredes desuden en pyritafstøbning af en højtspiret gastropod $(<1 \mathrm{~mm})$. Lignende pyritafstøbninger er ret hyppigt forekommende dybere i profilet, ved $1352 \mathrm{~m}$ og fra $1355 \mathrm{~m}$ og nedefter i de afsnit af nedre kridt, som her er opfattet som øvre hauterivien og øvre valanginien. De er alle kærneafstøbninger uden spor af fossilets overflade og eventuelle skulptur.

\section{Øvre hauterivien $1348-1360 \mathrm{~m}$}

Som hauterivien opfattes de følgende $12 \mathrm{~m}$ af den grå til gråsorte lersten. Heri kunne påvises 61 arter som nyintroducerede i Nøvlingprofilet. Blandt disse giver især følgende arter holdepunkt for at placere intervallet $\mathrm{i} ø \mathrm{v} r e$ hauterivien: Haplophragmium aequale, Marginulinopsis striatocostata, Wellmanella antiqua, Saracenaria bronnii, Vaginulina kochii og Conorotalites sigmoicosta. I prøven 1352-1355 m giver forekomsten af følgende tre arter: Wellmanella praeantiqua, Frondicularia rehburgensis og Conorboides hofkeri en mulighed for, at øvre valanginien er til stede. Saracenaria bronnii, der kendes som sjældent forekommende i øvre valanginien, er særlig hyppig i øvre hauterivien. Vaginulina kochii kendes både i øvre valanginien, hvor den er sjælden, i øvre hauterivien, hvor den når sit maksimum og i nedre plus mellem barrémien. De næstfølgende $2 \mathrm{~m}$ lersten indeholder 8 nyrepræsenterede arter, hvoraf een, Marginulinopsis breyeri, har en forekomst, der er begrænset til øvre hauterivien. Den er talmæssigt relativt velrepræsenteret i prøven. Seks af arterne har vertikale udbredelser, der ikke bidrager til en mere præcis stratigrafisk placering. Vaginulinopsis humilis praecursoria er kun fundet som et enkelt fragment. Stratum typicum er for denne art placeret i nedre del af øvre valanginien. Herunder følger endnu $3 \mathrm{~m}$ lersten, hvori introduceres andre 8 arter. Indslaget af arter hvis udbredelse omfatter mellem og øvre valanginien forstærkes, men kun to af dem: Verneuilinoides inaequalis og Epistomina caracolla anterior er i deres hidtil kendte vertikale udbredelse begrænset til valanginien. Dette nederste afsnit af intervallet 1348-1360 m er derfor også betragtet som øvre hauterivien.

Øve valanginien 1360-1371 m

De underliggende $11 \mathrm{~m}$ lersten viste sig at indeholde 18 nytilkomne arter, hvoraf følgende kan fremhæves som betydningsfulde for afsnittets stratigrafiske 
indplacering: Citharina pseudostriatula, hvis forekomst er begrænset til valanginien, Nodosaria regularis og Lenticulina saxonica når desuden op i hauterivien, Lingulina semiornata, en sjældent forekommende art, kendt i mellem og øvre valanginien, samt Buliminella loeblichi med stratum typicum i nederste del af øvre valanginien. Det ser således ud til, at lag af nedre hauterivien alder ikke er truffet i Nøvlingboringen.

\section{Mellem valanginien $1371-1394 \mathrm{~m}$}

Med 47 nytilkomne foraminiferarter træffes i det følgende afsnit en ændring i biofacies, der muligvis svarer til en mindre ændring i lithofacies. Af kurverne for neutron - gammastrålingen, der giver oplysninger om bjergarternes porositet, viser kurveforløbet en ændring i intervallet 1375-1380 m, der muligvis skyldes en forøget porositet. Dette kunne være udtryk for et større siltindhold i lerstenen. Da det er en almindelig iagttagelse i de danske dybdeboringer, at grænsen mellem valanginien-øvre valanginien ofte findes ved en tilsvarende lithologisk ændring, er det rimeligt at antage, at det ændrede kurveforløb kan korreleres med den iagttagne ændring i foraminiferindholdet. Af arter i nærværende interval med udbredelse i mellem valanginien er fundet: Marginulinopsis oldenburgensis, der kendes fra øvre mellem valanginien til nedre øvre valanginien, Conorboides valendisensis, der findes i mellem valanginien, Marginulina spinata og Pseudonodosaria sexcostata, to juraformer, der findes op i mellem valanginien, Citharina rudocostata, en anden juraform, hvis vertikale udbredelse strækker sig op i øvre valanginien, men som er fundet særligt hyppigt i mellem valanginien.

\section{Nedre kridt - jura $1394-(1483 \mathrm{~m})$}

Lagene umiddelbart under $1393 \mathrm{~m}$ indeholder ingen nytilkomne foraminiferarter. Den nedre grænse for mellem valanginien er kun baseret på den ret markante ændring af neutronkurven ved denne dybde. Det har ikke været muligt at konstatere nogen ændring i prøvematerialets lithologi, men hvis kurveforløbet kan forklares som udtryk for en øget porositet fra 1394 m og nedefter, er det sandsynligvis et større siltindhold, der er markeret. Nytilkomne foraminiferarter er igen registreret fra 1399 m ned til 1438 m, men kun i beskedent antal. Det drejer sig fortrinsvis om former, der kendes fra nedre kridt, men kendskabet til deres vertikale udbredelse gør det ikke muligt i denne forbindelse at præcisere nærmere, hvilken stratigrafisk placering lagene i det nedre afsnit har. I prøven 1405-1410 m er truffet en form, der her er betegnet som Saracenaria italica, og tilstedeværelsen af denne gør det muligt at antage, at afsnittet tilhører berriasien. 


\section{TALM $Æ S S I G T$ DOMINERENDE FORAMINIFERER}

For at udrede forholdet mellem nedfald og nytilkommet materiale i det fossilrige nedre kretaciske afsnit i Nøvling 1, er der gennemført en optælling af de enkelte foraminiferarters individantal i de 34 prøver. Af dette materiale skal her omtales nogle enkelte arter, der er talmæssigt dominerende inden for mere begrænsede profilafsnit.

Lenticulina muensteri (ROEMER 1839). I prøven 1337-1339 m, der i det biostratigrafiske afsnit er betegnet som aptien, er fundet et enkelt fragment, som med nogen usikkerhed er navngivet Lenticulina $c f$. muensteri. I den efterfølgende prøve 1339-1342 m, fandtes et sortfarvet eksemplar, der muligvis kan henføres til L. muensteri. Den første talstærke repræsentation af denne art findes dog først i den følgende prøve, 1342-1345 m, der er regnet til barrémien. Her fandtes 10 eksemplarer. Artens udbredelse er som tidligere nævnt (p. 106) fra nedre hauterivien til mellemste zone af nedre barrémien med enkelte eksemplarer i mellemste mellem barrémien. Hvis det kan fastslås, at arten har en tilsvarende vertikal udbredelse i det danske nedre kridt, er det muligt, at kun det nederste barrémien er til stede i Nøvlingprofilet. Generelt kan det siges om denne arts repræsentation, at den i alle de følgende prøver er til stede i stort tal, talrigest i 1352-1355 m, hvor antallet var 87, medens den iøvrigt når op på 20-30 eksemplarer pr. prøve.

En talmæssigt endnu større repræsentation opnås af Epistomina caracolla caracolla (ROEMER 1841). Denne art træffes øverst i Nøvlingprofilet med eet eksemplar i prøven 1345-1348 m. I den næstfølgende prøve fandtes den i et antal af 15 eksemplarer, og herfra og nedefter er den til stede i hver prøve, talrigest i prøven 1378-1383 m med 317 eksemplarer i det afsnit, der er betragtet som hørende til mellem valanginien. Der er iøvrigt ikke bemærket nogen korrelation mellem svingningerne i antallet af denne art fra prøve til prøve og disses stratigrafiske relationer, et forhold der også er bemærket i tilsvarende tyske undersøgelser udført på borekærner fra dybdeboringer (BARTENSTEIN \& BRAND 1951).

En tredie art, Marginulinopsis robusta (Reuss 1863), bør omtales i denne sammenhæng. Den når kun i enkelte prøver et antal i nærheden af $L$. muensteri, aldrig derover. Arten er talrigest til stede i intervallet $1371-1383 \mathrm{~m}$ med 17 eksemplarer i den øverste af de to prøver, og med 12 eksemplarer i den nederste $(1378-1383 \mathrm{~m})$. De to prøver hører biostratigrafisk til mellem valanginien. I prøven 1357-1360 m, der er regnet til øvre hauterivien, er arten fundet i 12 eksemplarer, medens den iøvrigt er til stede fra $1337 \mathrm{~m}$ (aptien) ned til og med $1438 \mathrm{~m}$ (?berriasien). Udbredelsen af denne art føjer intet nyt til den biostratigrafiske inddeling. Den kendes fra øvre valanginien op til albien. Dens forekomst i ældre afsnit i Nøvlingprofilet kan meget vel skyldes nedfald. 


\section{AFSLUTTENDE BEMÆRKNINGER}

Den del af den nedre kretaciske lagserie i Nøvling 1, som det har været muligt at datere på grundlag af foraminiferfordelingen, har en mægtighed på ca. $65 \mathrm{~m}$. En sammenligning med det tilsvarende afsnit af Vindingboringen, der blev udført ca. $16 \mathrm{~km} \mathrm{NNV}$ for Nøvling 1, og hvor man fandt en mægtighed på ca. $75 \mathrm{~m}$, viser en ret god overensstemmelse. I Vinding 1 er de $75 \mathrm{~m}$ inddelt i: berriasien?, valanginien, hauterivien, reduceret barrémien og albien. Der blev ikke fundet aptien. I Nøvling 1 blev observeret visse mindre forskelle fra Vindingdateringerne: nedre hauterivien mangler i Nøvling 1, men det antages, at lag af denne alder er til stede i Vinding 1. Desuden fandtes i Nøvling $15 \mathrm{~m}$ aptien, medens der ikke er rapporteret aptien i Vinding 1. Det er muligt, at disse uoverensstemmelser kan vises kun at være tilsyneladende ved en revision af materialet fra nedre kridt i Vinding 1, der blev boret i 1947.

Sedimentfølgen i nedre kridt afsnittene i de to boringer kan resumeres som følger: den nedre kretaciske finsandsten ved basis af dette interval overlejres af siltholdig lersten, der opadtil går over i lersten. Denne lersten får i tidens løb et øget kalkindhold og øverst udvikles brogede mergelsten, før sedimentationen afbrydes i løbet af albien tid. Beskrivelsen er som en illustration af sedimentationsforløbet $i$ et gradvist uddybende bassin med en mere regionalt omfattende afbrydelse af aflejringen gennem mellem og øvre albien.

ENGLISH SUMMARY

\section{LOWER CRETACEOUS IN NØVLING NO. 1}

Biostratigraphy based upon foraminifera

A total of 34 ditch samples representing the interval 1329-1483 m below Kelly Bushing were analyzed. (Depths corrected for lag-time according to table 1, p. 102). In the uppermost $70 \mathrm{~m}$ of this interval 247 species of foraminifera were encountered, 188 species of which were of significant importance for the biostratigraphic evaluation of this part of the section. A list of these species is shown in table 2, p. 103.

Age: Middle? and Lower Albian 1329-1337 $\mathrm{m}$.

Lithology: Claystone, sticky, highly calcareous, varicoloured reddish brown, dark brown, and greyish brown. At the very top of this interval (at $1329 \mathrm{~m}$ ) the presence of Hedbergella planispira indicates a Middle or a Lower Albian age. The remaining part of the interval, i.e. 1329-1337 $\mathrm{m}$ is Lower Albian with some probable indication of Aptian layers.

Age: Aptian 1337-1342 m.

Lithology: Claystone, sticky, calcareous, greyish brown.

Analysis of coloured specimens of foraminifera reveals that reddish and yellowish coloured sediments are represented in layers of an Albian age only. Haplophragmoides latidorsatus is introduced in the top part of this interval with a representation of 15 specimens indicating layers of the lowermost parts of the Aptian. 
Age: Barremian 1342-1348 m.

Lithology: Claystone, sticky, grey to greyish black.

From the content of foraminifera it appears that layers of the Upper, Middle, and Lower Barremian are present. In the lowermost part the presence of single specimens of Epistomina caracolla caracolla and Epistomina ornata might indicate that the top of the Upper Hauterivian should be placed above $1348 \mathrm{~m}$.

Age: Upper Hauterivian 1348-1360 $\mathrm{m}$.

Lithology: Claystone, sticky, grey to greyish black.

Haplophragmium aequale, Wellmanella antiqua and Saracenaria bronnii are among the total of 61 species which are introduced within this interval. Epistomina caracolla caracolla dominates in numbers of specimens. No indication of Lower Hauterivian.

Age: Upper Valanginian 1360-1371 m.

Lithology: Claystone, sticky, grey, greyish black, brownish grey.

Below $1364 \mathrm{~m}$ : Pyrite and clay ironstone present.

Introduction of 18 species the ranges of which indicate an Upper Valanginian age.

Age: Middle Valanginian 1371-1394 m.

Lithology: Claystone, sticky, with silt. Pyrite and clay ironstone present.

The introduction of 47 species might be correlated with changes in facies. Indication of a slightly higher porosity on gamma-neutron log. Presence of Conorboides valendisensis, Marginulina spinata, and Pseudonodosaria sexcostata.

For further information on the order of introduction of foraminiferal species in relation to the progress of drilling, see table 2, p. 103.

Outline of the subdivision of Lower Cretaceous in Nøvling 1

\begin{tabular}{|c|c|c|}
\hline corrected depth & & \\
\hline $1329-1337 \mathrm{~m}$ & \multicolumn{2}{|c|}{ (?Middle and) Lower Albian } \\
\hline $1337-1342 \mathrm{~m}$ & \multicolumn{2}{|l|}{ Aptian } \\
\hline $1342-1348 \mathrm{~m}$ & \multicolumn{2}{|c|}{ Barremian } \\
\hline $1348-1360 \mathrm{~m}$ & \multicolumn{2}{|c|}{ Upper Hauterivian } \\
\hline $1360-1371 \mathrm{~m}$ & Upper & \multirow{2}{*}{ Valanginian } \\
\hline $1371-1394 \mathrm{~m}$ & Middle & \\
\hline $1394-(1483 \mathrm{~m})^{*}$ & \multicolumn{2}{|c|}{ Lower Cretaceous - Jurassic } \\
\hline
\end{tabular}

* Final depth of this investigation.

\section{FINAL REMARKS}

The distribution of foraminifera has led to a biostratigraphical subdivision of about $65 \mathrm{~m}$ of Lower Cretaceous sediments in the Nøvling No. 1 deep test. Good correlation with another section of the same series could be established to the deep test of Vinding No. 1 - completed in 1947 - which is located about 10 miles to the NNW.

In Vinding No. 1 the thickness of the Lower Cretaceous was about $75 \mathrm{~m}$ comprising Berriasian?, Valanginian, Hauterivian, reduced Barremian, and Albian. No Aptian was reported. In Nøvling No. 1 minor differences in the age evaluation were noted: The Lower Hauterivian is missing, but in Vinding No. 1 it is assumed to be present. Furthermore, $5 \mathrm{~m}$ of Aptian was found in Nøvling No. 1 while in Vinding No. 1 the Aptian is not indicated. A revision of the Lower Cretaceous succession in Vinding No. 1 regarding the content of foraminifera is needed in order to straighten out these apparent discrepancies. 
The succession of sediments in the two sections might be outlined as follows: the Lower Cretaceous siltstone at the base of this interval is overlain by silty claystone, upwards changing into claystone. During the time of sedimentation the calcareous content of this claystone has increased. This description is the picture of a sedimentation in a gradually subsiding basin with an interruption of regional importance during Middle and Upper Albian time.

\section{LITTERATUR}

Albers, J., 1952. Taxonomie und Entwicklung einiger Arten von Vaginulina D'Orb. aus dem Barrême bei Hannover. (Foram.) - Mitt. Geol. Staatsinst. 21, Hamburg, p. 75-112.

Bartenstein, H. \& F. Bettenstaedt, 1962. Marine Unterkreide (Boreal und Tethys) in: Leitfossilien der Mikropaläontologie, Berlin, p. 225-297.

Bartenstein, H. \& T. Kovatcheva, 1970. Foraminiferen-Korrelationen der bulgarischNWdeutschen Barrême im Rahmen e iner weltweiten Kreidestratigraphie. - Rev. Bulgar. Geol. Soc. vol. 31, Sofia, p. 160-165.

Bettenstaedt, F., 1952. Stratigraphisch wichtige Foraminiferen-Arten aus dem Barrême vorwiegend Nordwest-Deutschlands. - Senckenbergiana, vol. 33, Frankfurt a. M. p. 263-295.

Buch, A., 1971. Marint nedre kridt i Rønde nr. 1 (1985-2103 m), - in L. BANKe Rasmussen m. fl. 1971 , p. 61-67.

Chapman, F., 1891-1898. The Foraminifera of the Gault of Folkestone, No. 1-10. Jour. Roy. Microsc. Soc. ser. 2, vol. 11-18, London.

Dam, A. Ten, 1950. Les Foraminifères de l'Albien des Pays-Bas. - Mém. Soc. géol. France, 63, Paris, p. 1-66.

Неснт, F. E., 1938. Standard-Gliederung der Nordwest-deutschen Unterkreide nach Foraminiferen. - Abh. senckenb. naturf. Ges. 443, Frankfurt a. M. p. 1-42.

HiltermanN, H. \& E. Kemper, 1969. Vorkommen von Valangin, Hauterive und Barrême auf Helgoland. - Ber. Naturhist. Ges. 113, Hannover, p. 15-37.

JANnIN, F., 1965. Contribution à l'étude du stratotype de l'Albien: variations des microfaunes dans la partie inférieur des argiles tégulines. - Rev. Micropaléont. vol. 8, Paris, p. 106-117.

Rasmussen, L. BANKe, et al., 1971. Dybdeboringen Rønde nr. 1 på Djursland. - Danm. Geol. Undersøg. 3. Række nr. 39, København, p. 1-123.

Reuss, A. E., 1863. Die Foraminiferen des norddeutschen Hils und Gault. - Sitzungsber. Wiener Akad. Wiss. math.-naturwiss. Classe, vol. 46, Wien, p. 5-100.

Sснотт, W., 1969. Paläogeographischer Atlas der Unterkreide von Nordwestdeutschland. Erläuterungen. Hannover, p. 1-315. 


\author{
DE NEDRE KRETACISKE \\ OG ØVRE JURASSISKE FORMATIONER \\ OG OSTRACODFAUNAER \\ I NØVLING NR. 1 \\ $(1329-1509 \mathrm{M})$ \\ af
}

Ole Bruun Christensen

De mesozoiske formationer er afgrænset af GUNNAR LARSEN (1966) for de jurassiske og nedre kretaciske afsnit i Det Danske Sænkningsområde. Denne inddeling søges bibeholdt ved beskrivelsen af disse aflejringer i Nøvling nr. 1 i fortsættelsen af den tidligere fremstillingsform af boringen Rønde nr. 1 (BRUUN Christensen 1971). Beskrivelserne foretages i den efterfølgende tekst og fremstilles skematisk i fig. 19. Undersøgelsen er baseret dels på de prøvebeskrivelser, der blev foretaget og indberettet til DGU af den udstationerede geolog (OLAF MiCHELSEN), dels på Schlumberger målinger i borehullet, samt på undersøgelser af ostracodpræparater.

Ostracoderne er ligesom foraminifererne udsorteret selvstændigt. Der er på få undtagelser nær fundet ostracoder i alle prøveintervallerne. Dele af finsandsaflejringerne i den nedre del af Vedsted formationen synes at være uden ostracoder. Gennem lagserierne varierer de boreintervaller, hvorfra prøverne er taget (cf. fig. 19):

Øvre del indtil $4455^{\prime}$ med 10 fods intervaller

$4455^{\prime}$ til $4770^{\prime}$ med 15 fods intervaller

Nedre del fra $4770^{\prime}$ med 30 fods intervaller

I nærværende artikel er der i biostratigrafisk henseende udelukkende taget hensyn til ostracodernes fordeling. I forbindelse hermed har det været muligt at påvise tilstedeværelse af lithostratigrafiske enheder, når disse er definerede, men ikke lithologisk genkendelige i skylleborede afsnit. Således er Børglum formationen, og øvre jurassiske aflejringer i det hele taget, blevet påvist i boringen indenfor området (f.eks. i de ældre boringer Vemb nr. 1 og Vinding nr. 1) på basis af ostracodundersøgelser (BRUUN CHRISTENSEN 1972).

Nøvling nr. 1 er beliggende i den sydvestlige del af Det Danske Sænkningsområde tæt op mod Ringkøbing-Fyn Hævningsområdet. Boringen er beliggende ca. 50 kilometer nord for boringen Grindsted nr. 1 og ca. 13 kilometer sydsydøst for boringen Vinding nr. 1. 


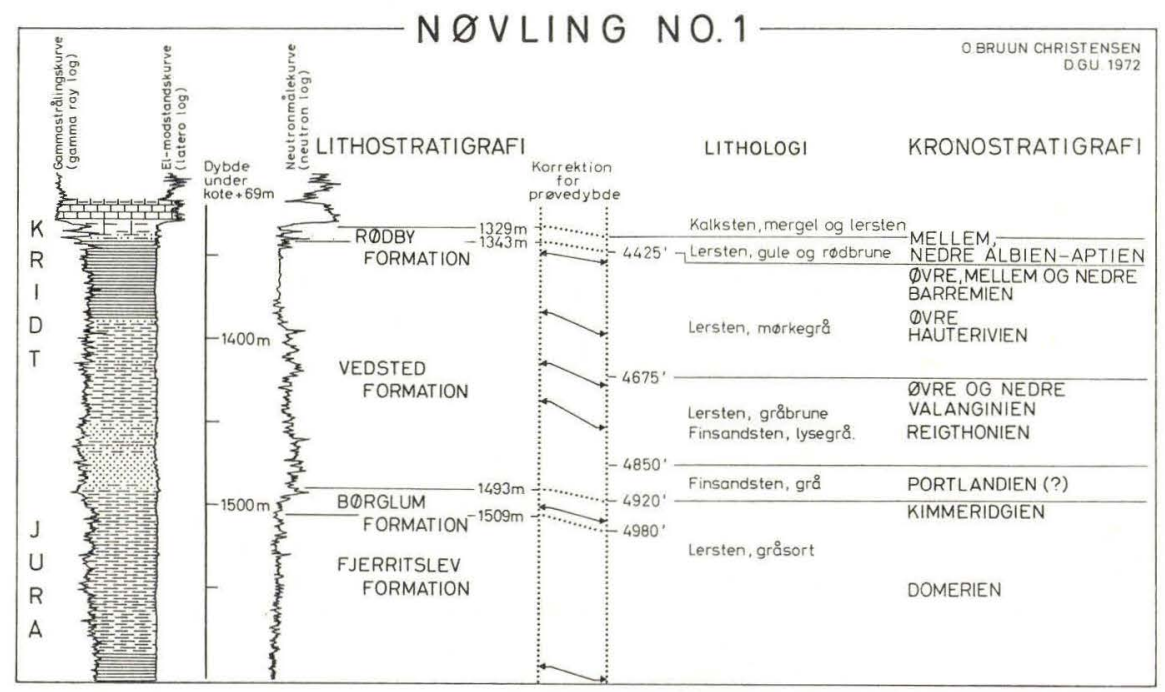

Fig. 19. De øvre jurassiske og nedre kretaciske formationer indsat i det lithologiske profil. Den skitserede chronostratigrafiske inddeling er baseret på ostracodernes fordeling $\mathrm{i}$ prøverne.

\section{STRATIGRAFISK INDDELING}

De her anvendte dybdeanvigelser er målt fra kelly bushing svarende til kote $+69,2$ meter. Angivelserne i engelske fod gælder udelukkende de originale dybdeangivelser på skylleprøverne. Disse dybder er korrigerede i de tilfælde, hvor de anføres i meter, nemlig ved hjælp af korrektionstests med farve eller carbid, samt Schlumberger målinger.

\section{Rødby formationen $(1329-1343 \mathrm{~m})$}

Sandsynligvis 14 meter lersten, ret fede, med forskellige gule og rødbrune farver, stærk kalkholdig. Finsandede, grålige lersten kan være tilstede i den nedre del af formationen eller som intercalationer i lagserien.

Mikrofossilerne fra denne formation er almindeligvis let genkendelige på grund af deres rødbrune farver. Karakterisk farvede ostracoder er af både mellem og nedre albien, samt aptien alder. Følgende stratigrafisk betydningsfulde arter kan nævnes: Dolocythere rara MERTENS 1956, Pontocyprella rara KAYE 1965, Pseudobythocythere goerlichi MERTENs 1956 og Veenia robusta KAYE 1964.

I prøven $4425^{\prime}-4435^{\prime}$ findes ostracoder fra øvre barremien. Disse kan hidrøre fra de finsandede, grålige lersten, der er iagttaget i formationen, men synes dog snarere at tilhøre de fede, mørke lersten i toppen af den underliggende Vedsted formation, skønt sedimenter herfra først er iagttaget i prøven $4445^{\prime}-4455^{\prime}$. Øvre barremien aflejringer synes i det hele taget at være af en relativ begrænset tykkelse. 
Vedsted formationen (1343-1493 m)

Lithostratigrafisk kan denne formation deles i tre led:

1. $4425^{\prime}-4675^{\prime}$ Lersten, fed, mørkegrå, stærk kalkholdig med pyrit og lerjernstenskonkretioner.

Den øverste prøve i dette interval indeholder som ovenfor nævnt ostracoder fra øvre barremien: Acrocythere hauteriviana anomala NEALE 1962 og Schuleridea (Schuleridea) hammi (TRIEBEL 1938), ligesom Orthonotacythere inversa tuberculata KAYE 1964 fra et dybere prøveniveau må hidrøre herfra.

Dette maksimalt 75 meter tykke led må overvejende modsvare zonen med Protocythere (Protocythere) triplicata (ROEMER 1840). Denne art er fundet i prøven $4445^{\prime}-4455^{\prime}$, hvor også de første bjergartsfragmenter fra leddet er iagttaget. Indexfossilet er yderst almindelig i prøverne derunder.

I den øverste prøve i leddet er der fundet fragmenter af ostracodskaller, der med nogen usikkerhed kan bestemmes som Exophthalmocythere mamillata TRIEBEL 1938. Denne art er karakteristisk for dele af valanginien og nederste hauterivien. Forfatteren har anset fundet for så usikkert, at han ikke har kunnet acceptere en hypotese om tektoniske forstyrrelser med repetation i lagserien. Hertil synes laghældningerne at være for regelmæssige (jvnf. HENRIKSEN p. 54). Fund af valanginien mikrofossiler begrænset til øverste prøver i leddet er derfor af forfatteren på basis af det undersøgte materiale blevet tolket som forurening.

Både nedre og mellem barremien synes at være tilstede foruden det ovenfor omtalte øvre barremien. Andre betydningsfulde arter fra dette interval er: Apatocythere (Apatocythere) simulans TRIEBEL 1940, Cythereis aculicostata TRIEBEL 1940 og Neocythere (Neocythere) protovanveeni KAYE 1963, der har deres førsteoptræden ved $4445^{\prime}$.

Leddet omfatter foruden lag af barremien alder også lag af hauterivien alder. Grænsen mellem disse kan sættes ved 4500', hvor følgende hauterivien arter optræder for første gang: Apatocythere (Apatocythere) spinosa NeAle 1962, Haplocytheridea ? sp., cf. kummi TrIEBEL, Gründel 1966. Arter som Acrocythere hauteriviana hauteriviana (BARTENSTEIN 1956), Apatocythere (Wendocythere) ellipsoidea TRIEBEL 1940, Cytherelloidea ovata pulchra NeALE 1960, Cytheropteron (Infracytheropteron) exquisita KAYE 1964, Dolocytheridea (Parasternbergella) intermedia neali GRÜNDEL 1966, Dicrorygma (Dicrorygma) speetonensis BRUUN CHRISTENSEN 1965, Eucytheridea (Vesticythrura) neocomiana neocomiana (KAYE 1964), Orthonotacythere inversa inversa (CORNUEL 1848), Protocythere (Protocythere) hechti TrIebel 1938, Schleridea (Schleridea) bilobata (TRIEBEL 1938) og Schuleridea (Schuleridea) thoerenensis (TRIEBEL 1938) er udbredt i øvre hauterivien og for de flestes vedkommende tillige i nedre barremien i Nøvling nr. 1.

Der er næppe nedre hauterivien i boringen. Fund i nedfald af arten Protocythere (Costacythere) frankei frankei (TRIEBEL 1938) kan antyde tilstedeværelse 8* 
af nedre hauterivien, men viser snarere tilstedeværelse af øverste valanginien i leddets nedre del eller i øvre del af underliggende led. Det er nemlig bemærkelsesværdigt, at danske aflejringer fra nedre hauterivien normalt plejer at være rige på ostracoder.

2. $4674^{\prime}-4850^{\prime}$ Lersten, fed, mørk gråbrun, stærk kalkholdig og med finsand, lysegrå til grå, glaukonitholdig og svag kalkholdig.

Fund af Schuleridea (Schuleridea) praethoerenensis BARTENSTEIN og BRAND 1951, samt Mandelstamia sexti sexti Neale 1961 i prøven 4710'-4725' og Stravia? crossata (NeAle 1962) fra dybere niveau viser, at valanginien er tilstede og sandsynliggør, at leddet omfatter både øvre og nedre valanginien. Desuden må grænsen mellem valanginien og reightonien (»berriasien «) sættes i samme prøve $\left(4710^{\prime}-4725^{\prime}\right)$. Som følge heraf må reightonien omfatte den største del af leddet.

I den underliggende Børglum formation i Nøvling nr. 1 findes arter som: Mandelstamia sexti sexti NeAle 1961, ? Galliaecytheridea teres (NeAle 1961) juv. og Galliaecytheridea compressa BruUn Christensen og Kilenyi 1970. Disse må anses for at være nedfald fra yngre aflejringsafsnit end den kendte Børglum formation med kimmeridgien faunaer. De to førstnævnte arter må antages at hidrøre fra Vedsted formationens nedre to led, mens eksemplarer af Galliaecytheridea compressa eventuelt kunne hidrøre fra den øverste del af Børglum formationen.

I boringen Vinding nr. 1 har forfatteren i kærneprøver fra den nederste del af Vedsted formationen kunne påvise »berriasien « (reightonien) og med en ostracodfauna, der næsten er identisk med faunaer i typeprofilet i Speeton.

3. $4850^{\prime}-4920^{\prime}$ Finsandsten, mørkegrå, glaukonitholdig og svag kalkholdig.

Dette led synes kun at indeholde kalkholdige fossiler i meget ringe mængde. Den ovenfor omtalte portlandien ostracod kan hidrøre fra dette afsnit.

Det er bemærkelsesværdigt, at der ved undersøgelserne af laghældningerne i borehullet synes at være krydslejring i disse finsandstensaflejringer (cf. HeNRIKSEN, p. 54). Dette træk kendes blandt andet også fra boringen Rønde nr. 1 i det aflejringsafsnit, der blev korreleret med Frederikshavn formationens øvre led i boringen Gassum nr. 1.

\section{Børglum formationen (1493-1509 m)}

Maksimalt 18 meter lersten, hård, sandsynligvis finsandet, gråsort, pyritholdig, svag kalkholdig.

Bortset fra nogle af de tidligere nævnte ostracodarter, der i dette dybdeinterval må antages at være nedfald, indeholder formationen næsten udelukkende øvre kimmeridgien arter. Disse findes i formationens øverste prøver. Af den rige ostracodfauna kan nævnes følgende arter: Aaleniella (Procytherura) gracilis 
BRUUn Christensen og KilenYi 1970, Dicrorygma (Orthorygma) reticulata BRUUn Christensen 1965, Galliaecytheridea spinosa Kilenyi 1969, Macrodentina (Polydentina) rudis MALz 1958, Macrodentina (Polydentina) wicheri (STEGHAUs 1951), Mandelstamia (Xeromandelstamia) tumida BRUUN CHRISTENSEN og KILENyI 1970, Protocythere cf. rodewaldensis (KLINGLER 1955) og Schuleridea (Schuleridea) moderata BRUUn Christensen og KiLENyi 1970.

\section{Fjerritslev formationen $(1509-1847 \mathrm{~m})$}

Mere end 300 meter tykke lag af lersten, finsandet (specielt i den øvre del), gråsort, pyritholdig, enkelte lerjernstenskonkretioner, svag kalkholdig.

En nøjere beskrivelse af formationen og formationens indhold af ostracoder, samt den stratigrafiske inddeling er foretaget af OlaF MiCHELSEN (side 124). Øverst mod Børglum formationen kan domerien faunaer erkendes. Nederst mod Vinding formationen (cf. BRUUN CHRISTENSEN side 132) findes hettangien faunaer.

\section{KONKLUSION}

Over nedre jurassiske, mørke lersten tilhørende Fjerritslev formationen følger den øvre jurassiske Børglum formation (fig. 19). Denne formation kan adskilles fra de underliggende aflejringer ved hjælp af ostracodindholdet. Lithologisk kan disse formationer vanskelig adskilles i boringer i denne del af bassinet. Den sandede, overvejende non-marine mellemjurassiske Haldager formation er ikke fundet i Nøvling nr. 1 eller andre boringer nær denne. Børglum formationen skønnes at være næsten 18 meter tyk i Nøvling nr. 1 og overvejende af kimmeridgien alder.

Vedsted formationen kan i Nøvling nr. 1 inddeles i tre led. Det nederste 20 meter tykke led kan eventuelt modsvare Frederikshavn formationen andre steder i Det Danske Sænkningsområde, men da de sandede aflejringer af reightonien alder i den nærliggende Vinding boring er henført til Vedsted formationen på basis af borekærnematerialer, undlades denne opspaltning i Nøvling nr. 1 .

Næstnederste led er over 50 meter tykt. De øverste prøver med reightonien ostracoder er iagttaget i den mellemste del af leddet. Den øverste mere lerede del af dette led tilhører nedre og øvre valanginien.

Det øverste 100 meter tykke led i Vedsted formationen består af lersten og er overvejende af øvre hauterivien alder. De øverste prøver indeholder ostracoder, der kan henføres til nedre og mellem barremien.

Rødby formationen, der har en sandsynlig tykkelse på 14 meter, består af gule og rødbrune ret fede lersten, måske mellemlejret af finsandede grålige lersten. Ostracodfaunaen indeholder arter fra øvre barremien, aptien, nedre og mellem albien. 


\section{THE LOWER CRETACEOUS AND UPPER JURASSIC FORMATIONS AND OSTRACOD FAUNAS IN NØVLING NO. 1}

Based on the studies of the ostracodfaunas from the borehole the Upper Jurassic Formation can be recognized to overlay the Lower Jurassic Fjerritslev Formation (fig. 19). Lithological the formations are difficult to separate in boreholes in the area. A sandy, mostly non-marine Middle Jurassic Haldager Formation has not been recognized in Nøvling No. 1 or in other borings in the neighbourhood of this. The Børglum Formation seems to be nearly 18 metres in thickness in Nøvling No. 1 and is of Kimmeridgian Age.

The Vedsted Formation in Nøvling No. 1 can be subdivided into three members. The lowermost one is 20 metres thick and may be classified as the Frederikshavn Formation. The next member is more than 50 metres thick. The uppermost samples containing Reightonian ("Berriasian") ostracods originate from the middle of the member. The uppermost, and more clayish part of the member is from Lower and Upper Valanginian.

The uppermost 100 metres thick member of the Vedsted Formation consists of claystone, and is mainly from Upper Hauterivian. The uppermost samples contain Lower and Middle Barremian ostracods.

The Rødby Formation seems to be 14 metres thick, and consists of yellow and reddish brown, greesy claystones perhaps interbedded with silty and greyish claystone. The ostracods are from Upper Barremian, Aptian, Lower and Middle Albian.

\section{LITTERATUR}

Christensen, O. BRUUn, 1971: De yngre jurassiske aflejringer og grænsen jura-kridt i Rønde nr. 1. (English Summary). - Danmarks Geologiske Undersøgelse, III. række nr. 39, pp. 68-73. - København.

Christensen, O. Bruun, 1972: Det Danske Sænkningsområdes udvikling i det Mellemste Mesozoikum. (English Abstract). Dansk geol. Foren., Årsskrift for 1971, pp. 55-62. København.

LARsen, G., 1966: Rhaetic-Jurassic-Lower Cretaceous Sediments in the Danish Embayment. - Danmarks Geologiske Undersøgelse, II. række nr. 91, pp. 128, 17 tavler. - København. 


\title{
JURA-BIOSTRATIGRAFI I NØVLING NR. 1 PÅ GRUNDLAG AF FORAMINIFERER
}

af

\author{
Inger Bang \\ Hertil tavle 3-5
}

Undersøgelsen omfatter prøverne fra 4890' (1482 m) til 6080' (1847 m), som angiver grænsen til rhæt (se O. Michelsen, p. 124), ialt 45 prøver, der alle kan henføres til juraperioden. En inddeling er endnu ikke foretaget af øvre og et eventuelt mellem jura, ligesom toppen af intervallet ikke er fastlagt. Foraminiferer af jurassisk alder optræder yderst sparsomt i prøverne, der helt er domineret af mikrofossiler fra nedre kridt. Fordelingen af de vigtigste foraminiferer fremgår af skemaet p. 121, og fremgangsmåden ved undersøgelsen har iøvrigt været den samme som ved Rønde nr. 1 (BANG 1971).

Der forekommer tilsyneladende forskellige faunaer. Den øverste fauna kan på grundlag af forekomsten af Planularia mariae KuZNETSOva, tavle 3, fig. 2, henføres til portlandien. En anden vigtig gruppe er Lenticulina 110-gruppen, der er beslægtet med Lenticulina comptula (SchwaGer) og L. irritita (ScHWAGER). Den forekommer i hele øvre jura og fortsætter i nedre kridt, med bl.a. arten Marginulinopsis robusta (Reuss). Det samme gælder Saracenaria sp. 3, tavle 3, fig. 5, der tilhører S. oxfordiana TAPPAN-gruppen (=S. »triquetra« aut. non $S$. triquetra (GüMBEL)).

Den øvre grænse for nedre jura, lias, er stærkt markeret, idet prøven 5010'$5040^{\prime}$ (1515-1523 m) indeholder en massiv fauna med foraminiferer, der kan henføres til øvre pliensbachien: Marginulina prima prima D'ORB., Geinitzinita pupa (TERQ.), tavle 6, fig. 7, 8, »Bolivina « liasica (TERQ.) form E, tavle 4, fig. 6, Darbyella turbiformis TERQ., enkelte Ophthalmidium sp., Ammodiscus sp. Ved korrelation til Rønde nr. 1 og Gassum nr. 1 synes det sandsynligt at henføre faunaen til »Bolivina« liasica - Darbyella turbiformis zonens nederste del (BANG 1971) og at den øvre del altså skulle mangle i Nøvling.

Foraminifererne er overordentligt velbevarede, og det gælder i det hele taget for alle liasprøverne, samtidig med at faunaerne er meget rige. Desværre lader deres optræden i prøverne formode, at foraminifererne ikke forekommer i prøverne i den oprindelige succesion, men er blandet sammen på grund af nedfald, hvorfor en inddeling af intervallet er beheftet med betydelig usikkerhed. Således må grænsen til Marginulina spinata zonen sættes ved den første optræden af Astacolus speciosus (TERQ.) (tavle 4, fig. 9) i prøven 5090'-5120' (1541$1548 \mathrm{~m}$ ), imens M. spinata (tavle 4, fig. 10) først optræder dybere. Faunaen domineres, ligesom i den overliggende zone, af »Bolivina «liasica, og karakteristisk 
er yderligere Geinitzinita praepupa (NøRVANG), Astacolus denticulata-carinata (Franke), Annulina metensis Terq. (tavle 4, fig. 11), Dentalina varians Terq. (tavle 4, fig. 13 og 14), Geinitzinita sp., Lenticulina sp.

Samme vanskelighed viser sig ved afgrænsningen af Nodosaria columnarisVaginulina listi zonen, idet de typiske arter tilsyneladende viser sig for lavt, $N$. columnaris således først fra prøven 5570'-5600' (1685-1694 m), hvorfor grænsen sættes ved øverste forekomst af Nodosaria issleri FRANKE i prøven $5270^{\prime}-5300^{\prime}$ (1597-1607 m). Af foraminiferer i zonen kan nævnes Reofax sp., Dentalina matutina D’OrB., Marginulina prima D'OrB., Geinitzinita sp., G. pupoides (Nørvang) (tavle 4, fig. 12), Nodosaria claviformis TerQ., N. mitis TERQ. \& Berthelin, Lenticulina sp.

»Neobulimina«-zonen forekommer fra prøven 5540'-5570' (1679-1685 m) med den karakteristiske fauna: Lenticulina sp. 26 (tavle 5, fig. 16 og 17), Astacolus quadricosta (TERQ.) (tavle 5, fig. 18), Trochammina nana (BRADY) form A BRAND (tavle 5, fig. 20). Lenticulina sp. 26 findes først fra 5570'-5536' (1685-1694 m) og nedefter og det synes, som om den i Jylland er begrænset til denne zone i modsætning til Øresundsboringerne, hvor den fortsætter op i den overliggende zone.

I Rønde nr. 1 kunne man ikke på grundlag af foraminiferer konstatere et nederste lias. Anderledes forholder det sig i Nøvling, hvor der også under »Neobulimina«-zonen viser sig nye arter: Geinitzinita tenuistriata (NøRVANG), G. substriata (NøRVANG) (tavle 5, fig. 19), Planularia inaequistriata (TERQ.) (tavle 5, fig. 22) samt »Involutina «liassica (JoNES) (tavle 5, fig. 21), der ikke før er truffet i Danmark. Det bør bemærkes, at »Involutina liassica her forekommer i en aflejring, bestående af ler- og siltsten (O. Michelsen, p. 124). Adskillige forfattere har efter WICHER 1952 nævnt arten som karakteristisk for rev-facies.

Zonen kan korreleres til Gassum nr. 1 og er i Rønde-rapporten kaldt Lingulina striata-zonen, skønt G. striata (Lingulina $=$ Geinitzinita DE CIVRIEUX \& DeSSAUVAGIE) såvidt vides kun er fundet i Gassum nr. 1 i det danske aflejringsbassin. En revision af nomenklaturen for zoneringen må dog afvente en palæontologisk revision af gruppen.

Med nogen usikkerhed på grund af boremetoden, der foruden de allerede nævnte ulemper kun tillader en bestemmelse af overgrænsen af zonerne og kun som formodet maximumsdybde til overgrænsen af zonen, kan liasserien inddeles:

1523-1548 m: Øvre pliensbachien (domerien)

1548-1607 m: Nedre pliensbachien

1607-1685 m: Øvre sinemurien

1685-1769 m: Nedre sinemurien

1769-1847 m: Hettangien 


\section{BIOSTRATIGRAPHY OF THE JURASSIC DEPOSITS IN NøVLING NO. 1 BASED ON FORAMINIFERA}

The investigation comprises the ditch samples from $4890^{\prime}(1482 \mathrm{~m})$ to $6080^{\prime}(1847 \mathrm{~m})$, indicating the boundary to the Rhaetic (O. MiCHELSEN det.), a total of 45 samples which may all be referred to the Jurassic. A subdivision of the Upper and possible Middle Jurassic has not yet been made, and likewise the top of the interval has not yet been determined definitively. Jurassic foraminifera are very scarce in the samples from $4890^{\prime}$ to $5010^{\prime}$, which are flooded with microfossils from the Lower Cretaceous. The occurrence of the supposedly most important species is shown in the table, and the method used is the same as the one applied in the report on Rønde No. 1 (BANG 1971). Apparently different faunas occur, of which the uppermost may be referred to Portlandian on account of Planularia mariae Kuznetsova (type Volgian and Portlandian), pl. III, fig. 2, in the sample 4920'-4950'. The Lenticulina sp. 110-group (pl. III, figs. 1, 4) has affinities to Lenticulina comptula (SCHWAGER) and L. irritita (SCHWAGER). The group may be found in the entire Upper Jurassic and may continue into Lower Cretaceous with among others the species Marginulinopsis robusta (Reuss). The same distribution applies to Saracenaria sp. 3 (pl. III, fig. 5) which belongs to the $S$. oxfordiana TAPPAN group ( $=S$. "triquetra" aut. non $S$. triquetra (GRÜMBEL)).

The upper boundary of Lower Jurassic, Lias, is very pronounced, as the sample 5010'$5040^{\prime}(1515-1523 \mathrm{~m})$ contains an abundant fauna of foraminifera which may be referred to Upper Pliensbachian (Domerian): Marginulina prima prima D'OrB., Geinitzinita pupa (TERQ.) pl. VI, fig. 7, "Bolivina" liasica (TERQ.) form E, pl. IV, fig. 6, Darbyella turbiformis TERQ., and a few Ophthalmidium sp., and Ammodiscus sp.

The foraminifera are extremely well preserved, as well as in the Lias as a whole, and comprise rich assemblages. Unfortunately their occurrence in the ditch samples seems to indicate that they are not found in the original succession, due to contamination. For instance the boundary to the Marginulina spinata Zone is placed at the first appearance of Astacolus speciosus (Terq.) (pl. IV, fig. 9) in the sample 5090'-5120' (1541-1548 m), while M. spinata (pl. IV, fig. 10) does not occur until lower down. The fauna as well as the one in the superjacent zone is dominated by "Bolivina" liasica (TERQ.) and is characterized by Geinitzinita praepupa (NørVANG), Astacolus denticulata-carinata (Franke), Annulina metensis Terq. (pl. IV, fig. 11), Dentalina varians Terq. (pl. IV, figs. 13 and 14), Geinitzinita sp., and Lenticulina sp.

The same difficulty appears in the defining of the Nodosaria columnaris-Vaginulina listi Zone, as the index species seems to appear too low, by reason of which the boundary is placed at the first appearance of Nodosaria issleri Franke in the sample 5270'-5300' (1597-1607 m). Foraminifera not shown in the table are: Reofax sp., Dentalina matutina D'Orв., Marginulina prima D'OrB., Geinitzinita sp., T. pupoides (NørVANG) (pl. IV, fig. 12), Nodosaria claviformis Terq., N. mitis Terq. \& Berthelin, and Lenticulina sp.

The "Neobulimina"-Zone is found from the sample 5540'-5570' (1679-1685 m), which contains the characteristic assemblage: Lenticulina sp. 26 (pl. V, figs. 16-17), Astacolus quadricosta (Terq.) (pl. V, fig. 18), and Trochammina nana Brady form A BRAND (pl. V, fig. 20). Lenticulina sp. 26 is found only in $5570^{\prime}-5600^{\prime}$ and seems in Jutland to be restricted to this zone.

In Rønde No. 1 the presence of the lowermost zone in Lias could not be established. In Nøvling, however, new forms appear below the "Neobulimina"-Zone and may be correlated to the lowermost Lias in Gassum No. 1: Geinitzinita tenuistriata (NøRVANG), G. substriata (Nørvang) (pl. V, fig. 19), Planularia inaequistriata (Terq.) (pl. V, fig. 22), and "Involutina" liassica (JoNES) (pl. V, fig. 21). It deserves notice that "Involutina" liassica is found in a 
deposit of shale and siltstone (O. MiChelsen, p. 130). Several authors have after WiCHER (1952) characterized the species as confined to reef-facies.

With some reservation on account of the boring method, which merely allows a determination of the maximum depth to the upper boundary of the zones, the Lias series is subdivided as follows:

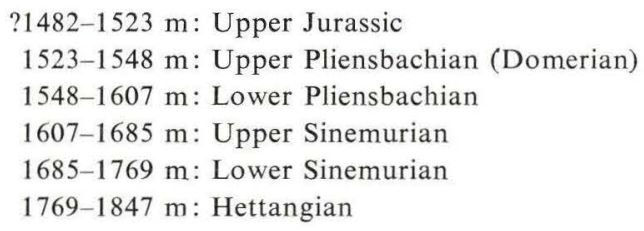

\section{LITTERATUR}

BANG, INGER, 1968: Biostratigrafisk analyse af kærneprøver fra Øresundsboringerne sommeren 1964 på grundlag af foraminiferer, pp. 63-73 (English Summary: Biostratigraphical investigation of the pre-Quaternary in the Øresund boreholes mainly on the basis of foraminifera, pp. 86-88), pl. 2-20 and 24, In: G. LARSEn, O. BRUUn Christensen, Inger BANG \& ARNE BUCH: Øresund, Helsingør-Hälsingborg Linien - D.G.U. rapport nr. 1. København.

BANG, INGER, 1971 : Jura aflejringerne i Rønde Nr. 1 (2103-2614 M). Biostratigrafi på grundlag af foraminiferer. (English Summary: The Jurassic Deposits in Rønde No. 1. Biostratigraphy Based on Foraminifera), In: L. BANKe RASMUSSEN (edit.): Dybdeboringen Rønde nr. 1 på Djursland. - D.G.U. III Rk., Nr. 39, pp. 74-80. København.

Bizon, G., 1960: Révision de Quelques Espèces-types de Foraminifères du Lias du Bassin Parisien de la Collection Terquem. - Revue de Micropal., Vol. 3, No. 1, pp. 3-18, Paris.

Brouwer, J., 1969: Foraminiferal Assemblages from the Lias of North-Western Europe. Verh. K. Ned. Akad. Wet., Afd. Natuurk., 1 Reeks, Deel. 25, No. 4, Amsterdam.

de Civrieux, J. M. Sellier \& Dessauvagie, T. F. J., 1965: Reclassification de quelques Nodosariidae, particulièrement du Permien au Lias. - Maden Tetkik be Arama Enst. Yayin., Publ. Inst. Etud. Rech. Min. Turg., No. 124, Ankara.

Kuznetsova, K. J., 1969: Sopolstavlenije Kimeridzkovo, Volzkovo i Portlandskovo Jurasou po Foraminiferam. - Izvestija Akademii Nauk SSSR, Seria Geologiseskaja 1969, No. 10, pp. 119-126, Moskva.

Norling, E., 1968: On Liassic nodosariid foraminifera and their wall structures. - Sver. Geol. Unders., Ser. C, No. 623, Stockholm.

Nørvang, A., 1957: The Foraminifera of the Lias Series in Jutland, Denmark. - Medd. Dansk Geol. Foren., Vol. 13, pp. 279-414, København.

Sigal, J. \& Ruget, C., 1967: Les Foraminifères du sondage de Laneuveville-devant-Nancy (Lotharingien de la région type). - Sciences de la Terre, Tome XII, no. 1-2, p. 33-70, 1 tabl., 9 pl. h.-t. Nancy.

Simon, W. (edit.), 1962: Leitfossilien der Mikropaläontologie. - Borntraeger, Berlin.

WICKer, C. A., 1952: Involutina, Trocholina und Vidalina - Fossilien des Riffbereichs. Geol. Jahrb. Bd. 66, pp. 257-284, Hannover. 
NEDRE JURA I NØVLING NR. 1

(1509-1847 M)

BIOSTRATIGRAFI BASERET PA OSTRACODER

af

Olaf Michelsen

Fra intervallet $5010^{\prime}-6320^{\prime}$ er samtlige prøver, ialt 49, undersøgt. Prøverne er udtaget med intervaller på 15, 20 og 30 fod. Efter tørring er sedimenterne nedbrudt ved behandling med benzin og kogende vand. Slæmningen er foretaget på en $0,1 \mathrm{~mm}$ sigte, og ostracoderne er udsorteret halvkvantitativt.

\section{LITHOLOGI}

Nedenstående oversigt over den gennemborede lagserie er baseret på forfatterens beskrivelse af vaskede og tørrede skylleprøver. De lithologiske enheder er korrigeret i forhold til Schlumbergermålinger. Dybder for prøver er i det følgende angivet $\mathrm{i}$ fod under kelly bushing, medens dybder omregnet til meter (under kelly bushing) er korrigeret ved lag time og i enkelte tilfælde i forhold til Schlumbergermålinger.

Ved sammenstilling af sedimentbeskrivelsen og Schlumbergermålinger kan afsnittet 1509-1847 m (prøverne 4980'-6080') henføres til Fjerritslev formationen. Denne er som helhed typisk udviklet som en lerstensserie med en finsandspræget nedre del. Formationens øvre del er, i lighed med de tilsvarende afsnit i boringen Vinding nr. 1, præget af mindre indslag af finsandsten. Fjerritslev formationens øvre grænse er fastlagt på biostratigrafisk grundlag. Den overlejres af den overvejende lerede Børglum formation og den finsandede Vedsted formation (jf. O. Bruun Christensen, p. 113). Den nedre grænse er lagt ved overgangen til en lerstensserie, der synes at veksle i mørkegrå, gråbrune, rødbrune og grøngrå farver og at være mellemlejret af finsandsten (se O. BruUn Christensen, p. 132). Denne grænse er fremkommet ved korrelation baseret på Schlumbergermålinger til boringerne Gassum nr. 1, Horsens nr. 1 og Rønde nr. 1.

Sedimenterne i Fjerritslev formationen (1509-1847 m) kan kortfattet beskrives således (se fig. 20):

Lersten, stedvis svagt finsandet, mørkegrå til gråsort, svagt kalkholdig; med pyrit og lerjernstenskonkretioner. I afsnittet over $1590 \mathrm{~m}$ findes interkalationer af finsandsten. I den nedre del af lerstensserien, under $1700 \mathrm{~m}$, er indholdet af finsand og finsandsten atter tiltagende. 


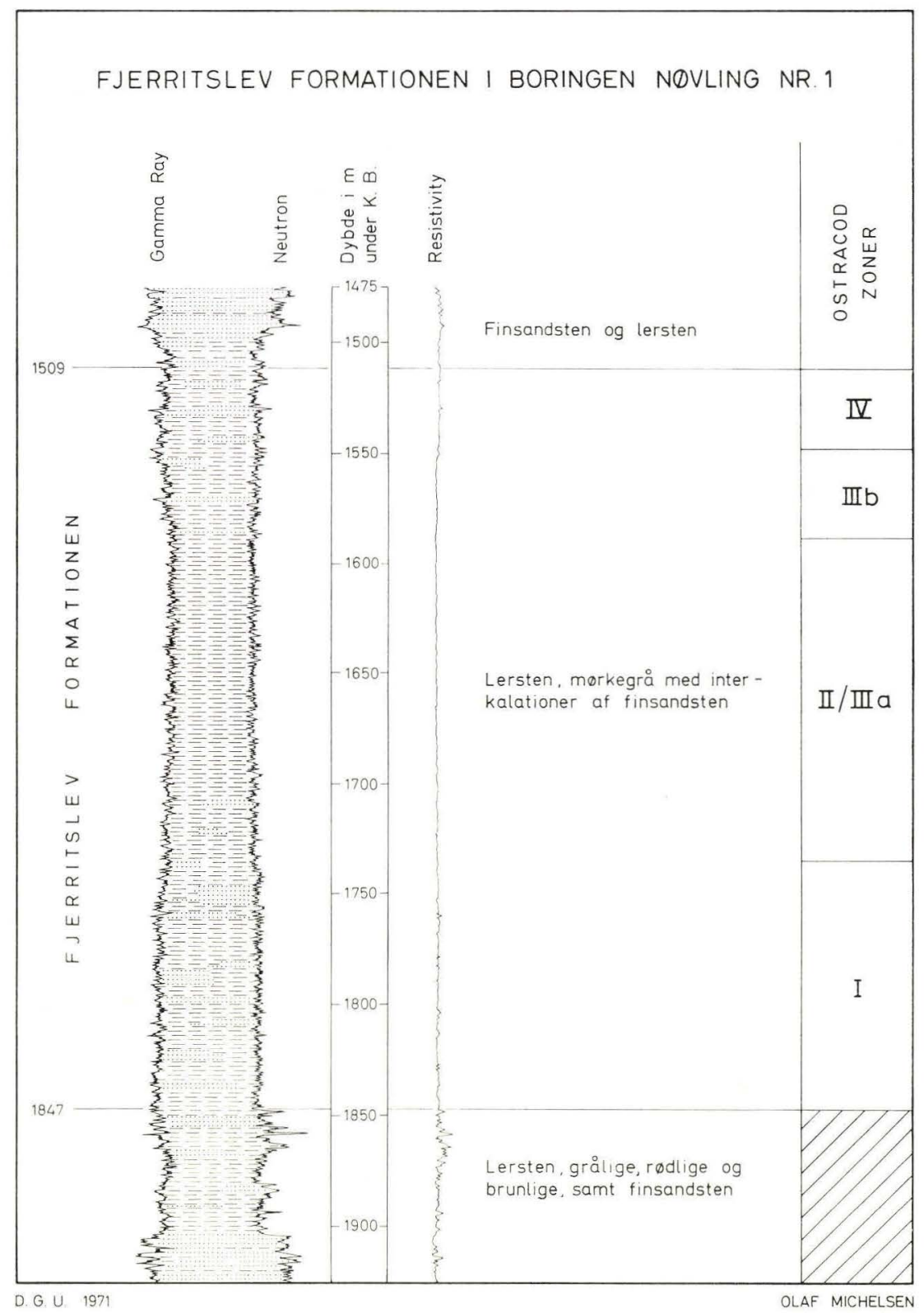

Fig. 20 


\section{BIOSTRATIGRAFI}

Den biostratigrafiske inddeling af lagserien er baseret på de samme forudsætninger som i boringen Rønde nr. 1 (jf. MicheLSEN 1971, p. 83). I Rønde nr. 1 er inddelingen udtrykt i seks zoner (I-VI), der stort set kan anvendes i hele Det Danske Sænkningsområde. Der er imidlertid visse svagheder ved definitionen af denne inddeling, idet den faunistiske udvikling i zonerne II og III er svag og uklar i området omkring boringerne Gassum nr. 1 og Rønde nr. 1. Samme tendens gør sig til en vis grad gældende for zone II i Nøvling nr. 1, men for hele den del af lagserien, der skal korreleres med zonerne II og III i Rønde nr. 1, er den faunistiske inddeling mere klar og lader sig sammenligne med såvel Gassum nr. 1 som med Øresundsboringerne nr. 10, 11, 12, 14 og 15.

Det højeste niveau for forekomst af nedre jura ostracoder findes umiddelbart under Fjerritslev formationens øvre grænse (1509 m), der derfor her regnes for den øvre grænse af nedre jura.

Den nedre grænse, trias-jura grænsen, er grundet manglende biostratigrafiske indicier lagt ved overgangen til den brogede lerstensserie, $1847 \mathrm{~m}$. Ostracodindholdet under denne dybde er aftagende, men dog af en betragtelig størrelsesorden, så det er muligt, at denne grænse er lagt for højt (se iøvrigt p. 127).

På fig. 21 er forekomsten af de vigtigste ostracoder gengivet i forhold til lagserien uden hensyntagen til, om denne forekomst i prøverne er primær eller skyldes nedfald (cavings).

\section{Ostracodzone I}

Denne zone findes i prøverne $5720^{\prime}-6080^{\prime}$, der svarer til den nedre del af Fjerritslev formationen, 1734-1847 m. Følgende ostracoder er karakteristiske:

Ogmoconchella aspinata (DREXLER 1958)

Procytheridea medioreticulata MICHELSEN 1970

Lophocythere elegans DREXLER 1958

Lophocythere sp. 4037

Lophocythere sp. 4076 MICHELSEN 1970

Macrocypris sp. 4023 MiCHELSEN 1970

$O$. aspinata er meget talrig og karakteristisk for zonen som helhed. Zone I's $\varnothing v r e$ grænse er lagt på grundlag af denne arts forekomst. $P$. medioreticulata og L. elegans findes kun i prøverne under $5840^{\prime}$. O. aspinata er en karakteristisk art for hele det tyske lias alpha, medens de to sidstnævnte arter kun kendes fra den midterste del. Lophocythere sp. 4037, L. sp. 4076 og Macrocypris sp. 4023 er sammen med de tre andre arter karakteristiske for de lag, der i Det Danske Sænkningsområde henføres til lias alpha, f.eks. i boringerne Gassum nr. 1 og Rødby nr. 1. Ogmoconcha hagenowi DREXLER 1958 er en hyppig art i hele zone I, medens Stenestroemia ? roedbyensis MicheLSEN 1970 kun er fundet nederst i lagserien, i prøven 6050'-6080'. 
Ostracodzone I er identisk med $O$. aspinata zonen (MiCHELSEN 1970), der i Det Danske Sænkningsområde antages at svare til hettangien og hele eller dele af nedre sinemurien. Det er sandsynligt, at grænsen mellem zone I og zone II/IIIa svarer til grænsen mellem nedre og øvre sinemurien, idet $P$. betzi (se nedenfor) er fundet i prøverne over denne grænse. Ostracodzone I's nedre grænse kan ikke med sikkerhed fastlægges, idet alle prøver er udtaget som skylleprøver. Som nævnt aftager antallet af ostracoder i prøverne under 6080'. Sammenholdt med ændringen i sedimenternes karakter (se p. 124) har dette dannet grundlag for, at denne dybde er antaget som zone I's nedre grænse, og dermed som grænsen mellem trias og jura. Imod denne antagelse taler imidlertid, at $S$. ? roedbyensis kun er fundet i prøven umiddelbart over grænsen, medens denne art i andre boringer (Gassum nr. 1, Rødby nr. 1 og Rønde nr. 1) findes et stykke oppe i zone I, O. aspinata zonen (MiChelsen 1970, pl. XVII). Korrelationer baseret på Schlumbergermålinger til boringerne Gassum nr. 1, Horsens nr. 1 og Rønde nr. 1 understøtter det rimelige $\mathrm{i}$ indtil videre at antage dybden 6080' for grænsen mellem trias og jura.

\section{Ostracodzone II/IIIa}

Denne zone omfatter prøverne $5240^{\prime}-5720^{\prime}$, der svarer til lagserien $1588-1734 \mathrm{~m}$. Følgende ostracoder er karakteristiske:

Ogmoconcha sp. 4041

Procytheridea aff. triebeli KLINGLeR \& NeUweILER 1959

Zonens øvre grænse er lagt ved det højeste niveau for disse to arters forekomst, samt for Procytheridea variabilis Klingler \& NeuweIler 1959. Omkring grænsen findes $P$. harpa KLINGLeR \& NeuweIler 1959 og $P$. cf. multiforata KLINGler \& Neuweiler 1959. Øverst i zonen er fundet få eksemplarer af $P$. ? apostulescui Gramann 1962. P. betzi Klingler \& Neuweiler 1959, P. laqueata Klingler \& Neuweiler 1959, P. auleata Gramann 1962 og Ogmoconcha hagenowi DreXLER 1958 findes i zonens nedre del. Disse arters relative optræden i zone II/IIIa svarer nøje til deres stratigrafiske fordeling i den øvrige del af Det Danske Sænkningsområde, bl.a. i boringerne Børglum nr. 1, Gassum nr. 1 og Øresundsboringerne nr. 10, 11, 14 og 15. I de tyske aflejringer har disse arter følgende stratigrafiske range: $P$. harpa findes omkring grænsen mellem lias beta og gamma, $P$. ? apostolescui kendes fra både lias beta og lias gamma, $P$. auleata kun fra lias beta, $P$. variabilis fra den øvre del af lias beta, $P$. laqueata og $P$. triebeli fra den nedre del, medens $P$. betzi er karakteristisk for zonen omkring grænsen mellem lias alpha og lias beta.

Ostracodzone II/IIIa svarer til zone II og den nedre del af zone III i boringen Rønde nr. 1 (jf. Michelsen 1971, p. 84-85). Zone II/IIIa kan genfindes i en række andre danske boringer og må betragtes som en mere veldefineret ostracodzone end de tilsvarende zoner i boringen Rønde nr. 1. På basis af ostracod- 


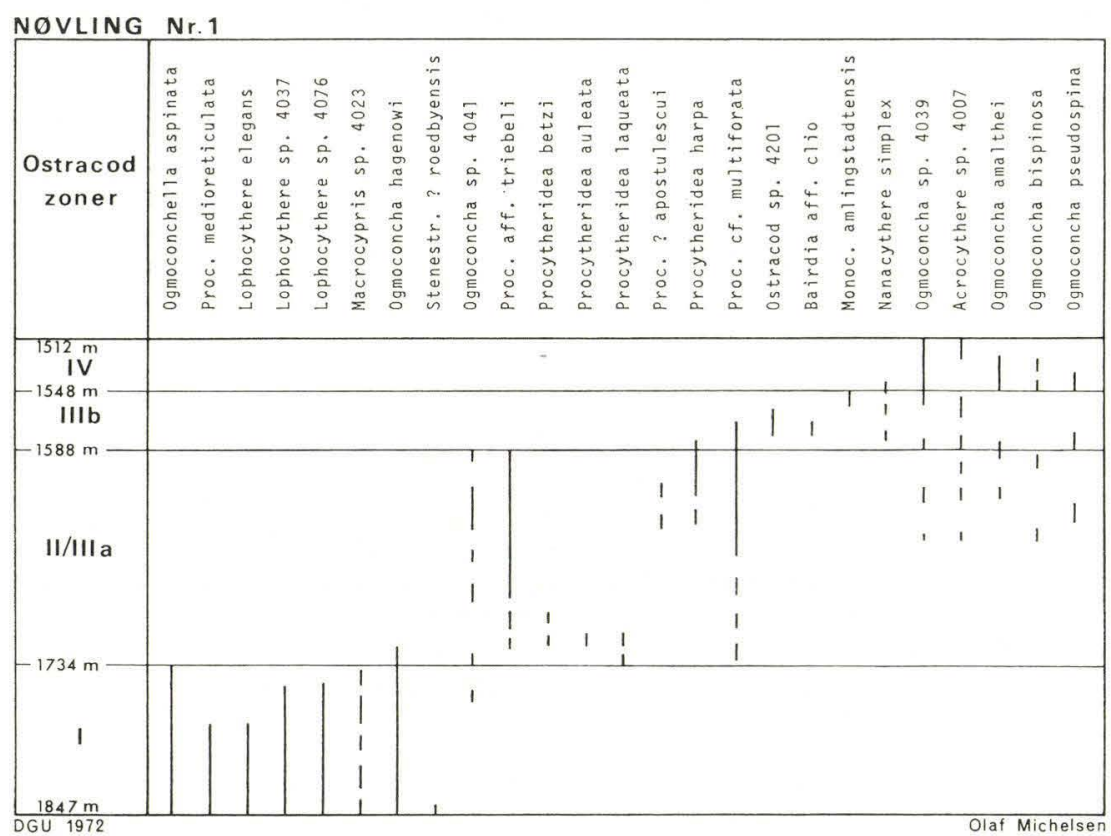

Fig. 21. Forekomsten af de vigtigste ostracoder og den derpå baserede zonering af nedre jura i Nøvling nr. 1. (Se også fig. 20).

The occurrence of the most important ostracod species and the zonation of the Lower Jurassic in Novling No. 1. (See fig. 20).

faunaen er det naturligt ved indirekte korrelation at henføre den til øvre sinemurien.

\section{Ostracodzone IIIb}

Denne zones fauna er fundet i prøverne $5120^{\prime}-5240^{\prime}$, der stammer fra lagserien $1548-1588 \mathrm{~m}$.

Zone IIIb er udskilt fra zone III i boringen Rønde nr. 1 på grundlag af Monoceratina amlingstadtensis TRIEBEL \& BARTENSTEIN 1938 i zone III b's øvre del, og Ostracod sp. 4201, Procytheridea cf. multiforata, Bairdia aff. clio Bizon 1960 og P. harpa i dens nedre del. M. amlingstadtensis er kendt fra lias gamma; ligeledes er den i boringen Gassum nr. 1 fundet i den øvre del af det afsnit, der er henført til lias gamma. P. harpa er, som ovenfor nævnt, karakteristisk for zonen omkring grænsen mellem lias beta og lias gamma. De fire øvrige arter findes sammen som et normalt faunaelement i de afsnit, der er henført til lias gamma i Øresundsboringerne.

Ostracodfaunaen i zone IIIb viser, at denne zone bør korreleres til pliensbachien. 
Ostracodzone IV

Zone IV findes i prøverne $5010^{\prime}-5120^{\prime}$, der svarer til intervallet $1512-1548 \mathrm{~m}$.

Følgende ostracoder er karakteristiske:

Nanacythere simplex Herrig 1969

Ogmoconcha sp. 4039

Acrocythere sp. 4007

De to sidstnævnte arter er begge karakteristiske for den nedre del af det afsnit, der er henført til lias delta i boringen Gassum nr. 1. De findes der sammen med $N$. simplex, der også kendes fra den øvre del af lias delta. Dette synes at være en normal fordeling af de tre arter i Det Danske Sænkningsområde. Ogmoconcha sp. 4039 er dog i enkelte tilfælde, bl. a. i boringen Børglum nr. 1, registreret i aflejringer, der biostratigrafisk skal henføres til zone IIIb. Faunaen indeholder iøvrigt Ogmoconcha amalthei (QUENSTEDT 1858), O. bispinosa GRÜNDEL 1964 og O. pseudospina Herrig 1969. Dette er alle arter, der er almindelige i lias delta, og enkelte af dem også i lias gamma.

Faunaen i zone IV er identisk med den tilsvarende zone i boringen Rønde nr. 1. Zone IV kan korreleres til den nedre del af den lagserie, der i Gassum nr. 1 er henført til lias delta. En indirekte korrelation til den nedre del af domérien er således naturlig.

\section{KONKLUSION}

I modsætning til boringen Rønde nr. 1 er Nøvling nr. 1 beliggende $\mathrm{i}$ den sydvestlige rand af Det Danske Sænkningsområde. Fjerritslev formationen er udviklet normalt i Nøvling nr. 1, som lersten der både i den øvre og den nedre del af formationen præges af finsand og finsandsten. På biostratigrafisk grundlag er det vist, at hele nedre jura ikke er tilstede, idet kun nedre lias og det meste af mellem lias er konstateret. Dette er en udvikling af nedre jura, der kan genfindes $\mathrm{i}$ boringen Horsens nr. $1 \mathrm{i}$ det omfang ostracodfaunaen er kendt $\mathrm{i}$ denne. En anden boring, der har en lignende beliggenhed i bassinet som Horsens nr. 1 og Nøvling nr. 1, er Vinding nr. 1. I sidstnævnte boring er kun konstateret ostracodfaunaer svarende til de to ældste zoner, I og II/IIIa, der må henregnes til nedre lias.

De ovenfor omtalte ostracodfaunaer i Nøvling nr. 1 er meget righoldige og giver gode muligheder for korrelationer. På basis heraf kan lagserien inddeles kronostratigrafisk på følgende måde:

1509-1548 m: nedre domérien.

1548-1588 m: pliensbachien.

1588-1734 m: øvre sinemurien.

1734-1847 m: hettangien og nedre sinemurien. 


\title{
LOWER JURASSIC IN NØVLING NO. 1
}

\author{
Biostratigraphy on the basis of ostracods
}

\section{LITHOLOGY}

The section is described on the basis of ditch samples and the Schlumberger logs, and is referred to the Fjerritslev Formation (cf. fig. 20, p. 125):

1509-1847 m: Claystone (shale), partly silty, dark grey to greyish black, slightly calcareous; with pyrite and clay ironstone. Above $1590 \mathrm{~m}$ with intercalations of siltstone. In the lower part of the section, below $1700 \mathrm{~m}$, the amount of silt and siltstone increases downwards.

The Fjerritslev Formation is underlain by a section with siltstone and dark grey, reddish brown, and greenish grey claystone (shale) and overlain by claystone and siltstone (see O. BruUn Christensen, p. 118, and 135). The position of the boundaries of the formation are corrected by means of correlations based on the Schlumberger logs to the Gassum No. 1, Horsens No. 1, and Rønde No. 1 borings.

\section{BIOSTRATIGRAPHY}

The biostratigraphic divisions are based on preliminary ostracod zones (see fig. 21, p. 128), as there has not yet been established a definitive zonation in the Lower Jurassic deposits in the Danish Embayment. The zonation here used is nearly identical with the one used in Rønde No. 1 (cf. Michelsen 1971). Zone II/IIIa in Nøvling No. 1 corresponds to zone II and to the lower part of zone III in Rønde No. 1, and zone III b in Nøvling No. 1 to the upper part of zone III in Rønde No. 1.

The ostracod faunas in Nøvling No. 1 are rich in individuals and in species, and are very well preserved. They give a good basis of correlation with both the other parts of the Danish Embayment and the German sections. In fig. 21 the most important species are shown in relation to the section and its zonation. Because of the samples being taken as ditch samples, only the uppermost occurrence of each species can be used for the stratigraphical determination.

Ostracod zone I (1734-1847 m) is identical with the $O$. aspinata Assemblage Zone (cf. MiCHELSEN 1970, p. 15). The fauna is characteristic of the sections referred to Lias Alpha in the Gassum No. 1 and Rødby No. 1 borings. The lower boundary of this zone in Nøvling No. 1 is questionable because of the missing biostratigraphical indications. The depth, $1847 \mathrm{~m}$, of this boundary is chosen on the basis of the change in lithology.

Ostracod zone II/IIIa $(1588-1734 \mathrm{~m})$ shows resemblances to the faunas in the German Lias Beta. It is a fauna usually found in corresponding sections in the Danish Embayment. Ogmoconcha sp. 4041 is a species which often is very abundant in this type of fauna, but which also occurs in a fauna corresponding to that of Lias Gamma.

Ostracod zone IIIb $(1548-1588 \mathrm{~m})$ is correlated with Lias Gamma. Sections containing this fauna in the Danish Embayment often are dominated by $P$. $c f$. multiforata, and are characterized by $P$. harpa in the lower part of the sections.

Ostracod zone IV $(1512-1548 \mathrm{~m})$ is referred to Lias Delta, and seems when compared with the fauna in Gassum No. 1 to correlate only with the lower part of Lias Delta, since the assemblage with $N$. simplex, Ogmoconcha sp. 4039 and Acrocythere sp. 4007 is known only from the lowest part of the section referred to Lias Delta in that boring. 


\section{Chronostratigraphy}

1509-1548 m: Lower Domerian.

1548-1588 m: Pliensbachian.

1588-1734 m: Upper Sinemurian.

1734-1847 m: Hettangian and Lower Sinemurian.

\section{LITTERATUR}

Drexler, E., 1958. Foraminifera und Ostracoden aus dem Lias alpha von Siebeldingen/ Pfalz. - Geol. Jb., Bd. 75, pp. 475-554. - Hannover.

Herrig, E., 1969. Ostracoden aus dem Ober-Domerien von Grimmen westlich Greifswald. I \& II. - Geologie, h. 4, pp. 446-471 \& 1072-1101. - Berlin.

KLINGLER, W. \& NeUWEILER, F., 1959. Leitende Ostracoden aus dem deutschen Lias beta. Geol. Jb., Bd. 76, pp. 373-410. - Hannover.

Klingler, W., 1962. Lias Deutschlands. - In: Simon, W. \& Bartenstein, H., 1962. Leitfossilien der Mikropaläontologie, pp. 73-122. - Berlin.

Larsen, G., 1966. Rhaetic-Jurassic-Lower Cretaceous Sediments in the Danish Embayment. (A Heavy-Mineral Study). - Danmarks Geologiske Undersøgelse, II. række, nr. 91. - København.

- , Christensen, O. Bruun, Bang, I. \& Buch, A., 1968. Øresund. Helsingør-Hälsingborg Linien. - Danmarks Geologiske Undersøgelse, rapp. nr. 1. - København.

Michelsen, O., 1970. - In: Bertelsen, F. \& Michelsen, O., 1970. Megaspores and Ostracods from the Rhaeto-Liassic Section in the Boring Rødby No. 1, Southern Denmark. - Danmarks Geologiske Undersøgelse, II. række, nr. 94. - København.

- 1971. Nedre jura og nederste mellem jura i Rønde nr. 1. Biostratigrafisk undersøgelse på grundlag af ostracoder (English Summary). - In: RaSMusSEN, L. BANke (red.), 1971. Dybdeboringen Rønde nr. 1 på Djursland. - Danmarks Geologiske Undersøgelse, III. række, nr. 39. - København. 


\title{
VINDING FORMATIONEN (ØVRE TRIAS) \\ I NØVLING NR. 1
}

af

\author{
Ole Bruun Christensen
}

\section{INDLEDNING}

De rhaetiske aflejringer på overgangen mellem jura og trias er i Det Danske Sænkningsområde blevet henført til forskellige formationer (LARSEN 1966). Forfatteren har skønnet, at disse aflejringer i Nøvling nr. 1 bør sammenfattes under betegnelsen Vinding formationen. I nærværende sammenstilling af vort geologiske kendskab til dette boreafsnit i Nøvling nr. 1 følges nøje den fremgangsmåde der blev benyttet ved gennemgangen af de tilsvarende afsnit i boringen Rønde nr. 1 (BRUUN CHRISTENSEN 1971).

Den oprindelige beskrivelse af aflejringerne blev foretaget på borestedet af OLAF MiCHELSEN på basis af bjergartsfragmenterne i skylleprøverne (»cuttings «). Fordelingen af disse forskellige bjergartstyper er sammenstillet af ARNE DINESEN (side 136). OlAF MiCHELSEN kunne også meget tidligt på basis af ostracodtyper lokalisere rhaet og keuper afsnit i boringen.

Under Vinding formationen i Nøvling nr. 1 er de triassiske aflejringer karakteristiske ved at indeholde anhydrit mellem kalksten, lerede, grålige finsandsten, samt lersten, finsandet, gråbrun og rødbrun, svag kalkholdig. Der er i Nøvling nr. 1 ikke fundet fossiler fra andre triassiske afsnit end rhaet og øverste keuper.

\section{Vinding formationen (1847-1996 m)}

Denne formation er vanskelig at afgrænse. Dette på trods af, at formationen er opstillet i den relativt nærliggende boring Vinding $\mathrm{nr} .1 \mathrm{ca} .13$ kilometer mod nordnordvest (LARSEN 1966). En korrelation af de lithologiske træk i de to boringer vanskeliggøres især ved, at der ikke er udført Schlumberger undersøgelser i boringen Vinding nr. 1.

Vinding formationen er i Vinding nr. 1 defineret ved en marin lagrække af mørkegrå til næsten sorte leraflejringer med underordnede meget tynde sandstensbånd med en samlet tykkelse på ialt ca. 180 meter (LARSEN 1966). Af boreprofiler fremgår det desuden, at aflejringerne indeholder en del kalksten, især i den nedre del. Beskrivelserne er foretaget på basis af skylleprøver og to borekærner fra henholdsvis den midterste del og den nederste del af boreafsnittet.

Lithologiske korrelationer kan foruden med Vinding nr. 1 også i nogen udstrækning foretages med Vemb nr. 1, beliggende i en afstand af ca. 35 kilometer nordvest for Nøvling nr. 1. 


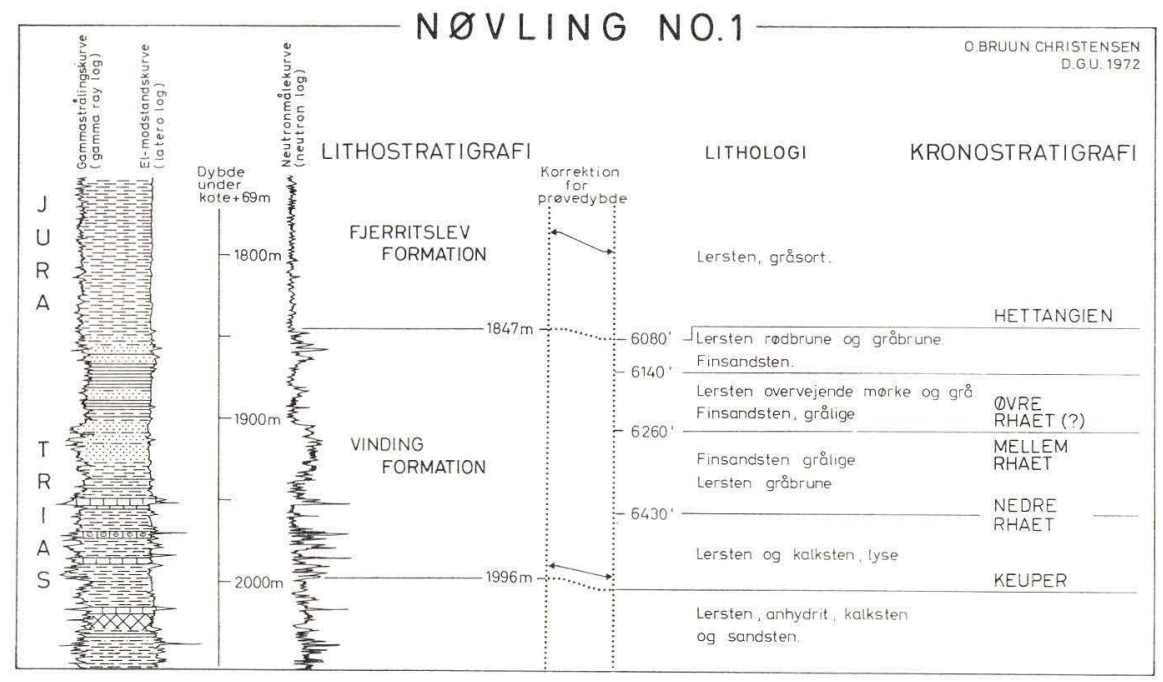

Fig. 22. Vinding formationen afgrænset i det lithologiske profil. Den skitserede chronostratigrafiske inddeling er baseret på biostratigrafiske undersøgelser af prøverne.

I Nøvling nr. 1 synes Vinding formationen at kunne opdeles i fire led. De to øverste led (6080'-6260' prøvedybde) synes at være uden rester efter foraminirer og ostracoder. Lithologisk kan disse led på basis af det foreliggende lokaliseres såvel under Fjerritslev formationen som under Gassum formationen, men kan gennem korrelation til Vinding nr. 1 betegnes: Vinding formationen. Aflejringerne må antages at være dannet marginalt ved bassinets sydvestlige kant. Langs bassinets nordlige dele har marine nedre jurassiske ostracoder (»Procytheridea «) været registreret i Gassum formationen (Flyvbjerg nr. 1) af forfatteren. Bestemmelsen er senere verificeret gennem fund af et megasporeselskab karakteristisk for den nederste del af lias (meddelelse af FinN BERTHELSEN, D.G.U.).

\section{Øverste led $\left(6080^{\prime}-6140^{\prime}\right)$}

Dette led i Vinding formationen (se fig. 22) består af ca. 18 meter lersten, overvejende svag finsandet, rødbrun, kalkholdig, veksellejret med fede, lys grøngrå og svagt finsandede, lys gråbrune, kalkholdige lersten. Desuden er der iagttaget hvide, glimmerholdige, kalkholdige og glaukonitholdige finsandsten.

\section{Nastøverste led $\left(6140^{\prime}-6260^{\prime}\right)$}

Næsten 40 meter lersten, overvejende fede og mørke, sjældnere med lyse og brune farver, kalkfrie, vekslende med finsandet, grå, glimmerrige og kalkholdige lersten. Almindelige i skylleprøverne er også lyse, grå og glimmerholdige finsandsten. 
Nastnederste led $\left(6260^{\prime}-6430^{\prime}\right)$

Består maksimalt af 57 meter finsandsten i lyse og grålige farver, kalkfri til svag kalkholdig, pyritholdig, ofte glimmerrige, vekslende med gråbrune lersten.

Nederste led $\left(6430^{\prime}-6580^{\prime}\right)$

Dette ca. 40 meter tykke led består af lersten med kraftige indslag af hvidlig og grå kalksten øverst og nedefter af finkornede, dolomitiske, lys gulliggrå kalksten.

\section{BIOSTRATIGRAFI}

I Nøvling nr. 1 er udbredelsen af fossilerne i Vinding formationen meget lig den, der kan findes i rhaet aflejringerne i andre boringer i Det Danske Sænkningsområde. I den nærliggende boring Vinding nr. 1 er der i de tilsvarende boreafsnit fundet den stratigrafisk betydningsfulde Rhaetavicula contorta (PORTLOCK) i borekærnemateriale. I prøver fra væsentligt dybere triassiske aflejringer i samme boring er der fundet ostracoder og chara-oogoniter. I Nøvling nr. 1 er sådanne fossiler ikke iagttaget i tilsvarende niveauer. Kun i lag fra rhaet og aller øverste keuper er der fundet mikrofossiler.

I oversigten til boringen. Rønde nr. 1 (BRUUN CHRISTENSEN 1971) er der givet en biostratigrafisk inddeling af keuper-rhaet afsnit i Det Danske Sænkningsområde.

I Nøvling nr. 1 er de to øverste led af Vinding formationen (6080'-6260') som ovenfor beskrevet uden rester efter foraminiferer og ostracoder. Næstnederste led i formationen $\left(6260^{\prime}-6430^{\prime}\right)$ indeholder i den øverste, sandede del agglutinerede foraminiferer af forskellig type, som ikke synes at hidrøre fra højere niveauer. Den nederste del af leddet kan underdeles i to zoner. Ligeså det dybest liggende led.

a. Zonen med Emphasia (Rhombocythere) penarthensis $\left(6330^{\prime}-6380^{\prime}\right)$ med E. (Rhombocythere) penarthensis ANDERSON 1964, E. (Rhombocythere) wicheri ANDERSON 1964 og E. (Gemmanella?) media n. sp. (WILL 1969)

b. Zonen med Emphasia (Notocythere) ruegeri $\left(6380^{\prime}-6530^{\prime}\right)$ med E. (Notocythere ruegeri ANDERSON 1964 og E. (Rhombocythere) obliqua (WILL 1964) som vigtigste arter i formationens næstnederste led og desuden med Darwinula liassica JoNEs 1894, E. (Notocythere) nodosa (WILL 1969), Limnocythere keuperea WILL 1969, Nov. gen. hoffmanni (WILL 1969) og Limnocythere sp. 117 BRUUN CHRISTENSEN 1962 som eksempler på arter fra den øverste del af nederste led i formationen.

c. Zonen med Emphasia (Gemmanella?) nov. sp. 106 (ved 6530') med E. (Gemmanella?) nov. sp. 106 (BRUUN CHRISTENSEN 1962), Darwinula major JONES 1894 og E. (Gemmanella?) tuberosa (WILL 1969) umiddelbart ved eller under lag af oolitisk kalksten. 


\title{
STRATIGRAFISK KONKLUSION
}

Aflejringerne på overgangen mellem trias og jura i Nøvling nr. 1 er benævnt Vinding formationen (fig. 22) på basis af den inddeling, der tidligere er foretaget i den nærliggende boring Vinding nr. 1 .

En stratigrafisk korrelation til anden side, for eksempel med boringen Rønde nr. 1, sandsynliggør, at den øverste del af Vinding formationen modsvarer Gassum formationen, mens den øverste del af Vinding? formationen i Rønde nr. 1 er stærkt beslægtet med den nedre kalkstenførende del af Vinding formationen.

Vinding formationen i Nøvling nr. 1 kan inddeles i fire led, som alle synes at indeholde lersten. Nederste led tillige med kalkstenaflejringer og de tre øverste led tillige finsandstenslag.

Nederste led indeholder ostracodfaunaer fra overgangen mellem keuper og nederste rhaet. Det drejer sig om de ældste triassiske fossiler, der er registreret i boringen. Ved denne overgang optræder tillige oolitiske kalksten som vidnesbyrd om en kraftig marin transgression.

Næstnederste led indeholder to nedre rhaetiske ostracodzoner og i den øvre del muligvis mellem rhaetiske foraminiferer. Der er ikke fundet stratigrafisk anvendelige fossiler i formationens to øverste led. Dele af disse kan ligesåvel tilhøre den overliggende Fjerritslev formation.

\author{
ENGLISH SUMMARY \\ THE VINDING FORMATION (UPPER TRIASSIC) IN \\ NØVLING NO. 1
}

The deposits between the Triassic and the Jurassic are classified as the Vinding Formation. In the boring Nøvling No. 1 they may be subdivided into four members, all of which seem to contain claystone. The lowermost member includes limestone and the three uppermost members include beds of siltstone.

The lowermost member contains ostracod faunas from the boundary Keuper-Rhaetic. These are the oldest Triassic fossils in the boring. Close to this boundary a bed of oolitic limestone gives an indication of a major transgression in the area.

The next middle member consists of two Lower Rhaetic ostracod zones and perhaps Middle Rhaetic foraminiferas in the upper part. There have not been recognized any fossils in the uppermost two members of the formation. Parts of these may just as well be parts of the Lower Jurassic Fjerritslev Formation.

\section{LITTERATUR}

Christensen, O. Bruun, 1971: Biostratigrafiske undersøgelser af trias i Rønde nr. 1 og trias-jura grænseområdet. (English Summary). - Danmarks Geologiske Undersøgelse, III. række nr. 39, pp. 89-93. København.

LARSEN, G., 1966: Rhaetic-Jurassic-Lower Cretaceous Sediments in the Danish Embayment. - Danmarks Geologiske Undersøgelse, II. række nr. 91, pp. 128, 17 tavler. København. 


\title{
TRIAS I NøVLING NR. 1
}

\author{
$(1847-3423 \mathrm{M})$
}

af

\section{Arne Dinesen}

\section{INDLEDNING}

De biostratigrafiske forhold i den øverste del af trias-profilet (1847-1999 m) er behandlet foran af O. BRUUN CHRISTENSEN (p. 132). I størstedelen af den triassiske lagserie savnes fossiler, og den følgende gennemgang bygger udelukkende på data, der har tilknytning til de lithologiske egenskaber. Ligesom for Rønde nr. 1's vedkommende (DINESEN 1971) betegner inddelingen et foreløbigt resultat, der er baseret på en sammenstilling af skylleprøvebeskrivelser, radioaktivitetsmålinger og boretekniske oplysninger.

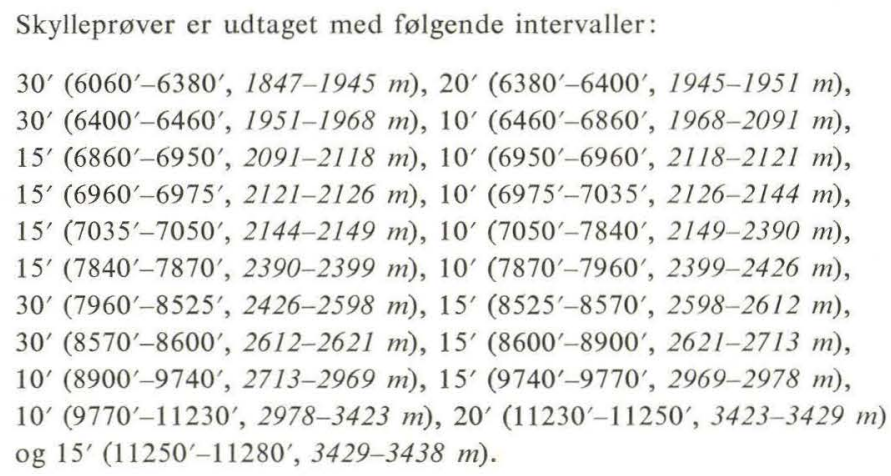

Inden for det omhandlede afsnit af boringen foreligger skylleprøver i et samlet antal af 443 stk. Da boringen kun var udbygget med foringsrør ned til $3509^{\prime}(1070 \mathrm{~m}$ ) under kelly bushing, kan »nedfald «(caving) fra vidt forskellige lag optræde $\mathrm{i}$ alle prøver.

Beskrivelse af skylleprøverne (herunder udskillelse af »cuttings«-typerne 18-47A) udførtes på borestedet af O. MiChelsen (6060'-9680') og T. JuHL HANSEN $\left(9680^{\prime}-11280^{\prime}\right)$. Beskrivelserne danner grundlag for udarbejdelsen af diagrammet fig. 23. Diagrammet viser tillige andre data som boretider, radioaktivitetskurver og »lag distances«, der er af betydning for den lithologiske tolkning og inddeling.

Det bemærkes, at målinger af elektrisk modstand og lydhastighed (laterolog og sonic log) foreløbig kun i meget begrænset omfang er inddraget i bearbej- 
TRIAS. Grundlag for lithologisk inddeling (1847-3423 m)

DANMARKS GEOLOGISKE UNDERSØGELSE

TRIASSIC Basis for lithologic subdivision (1847-3423 m)

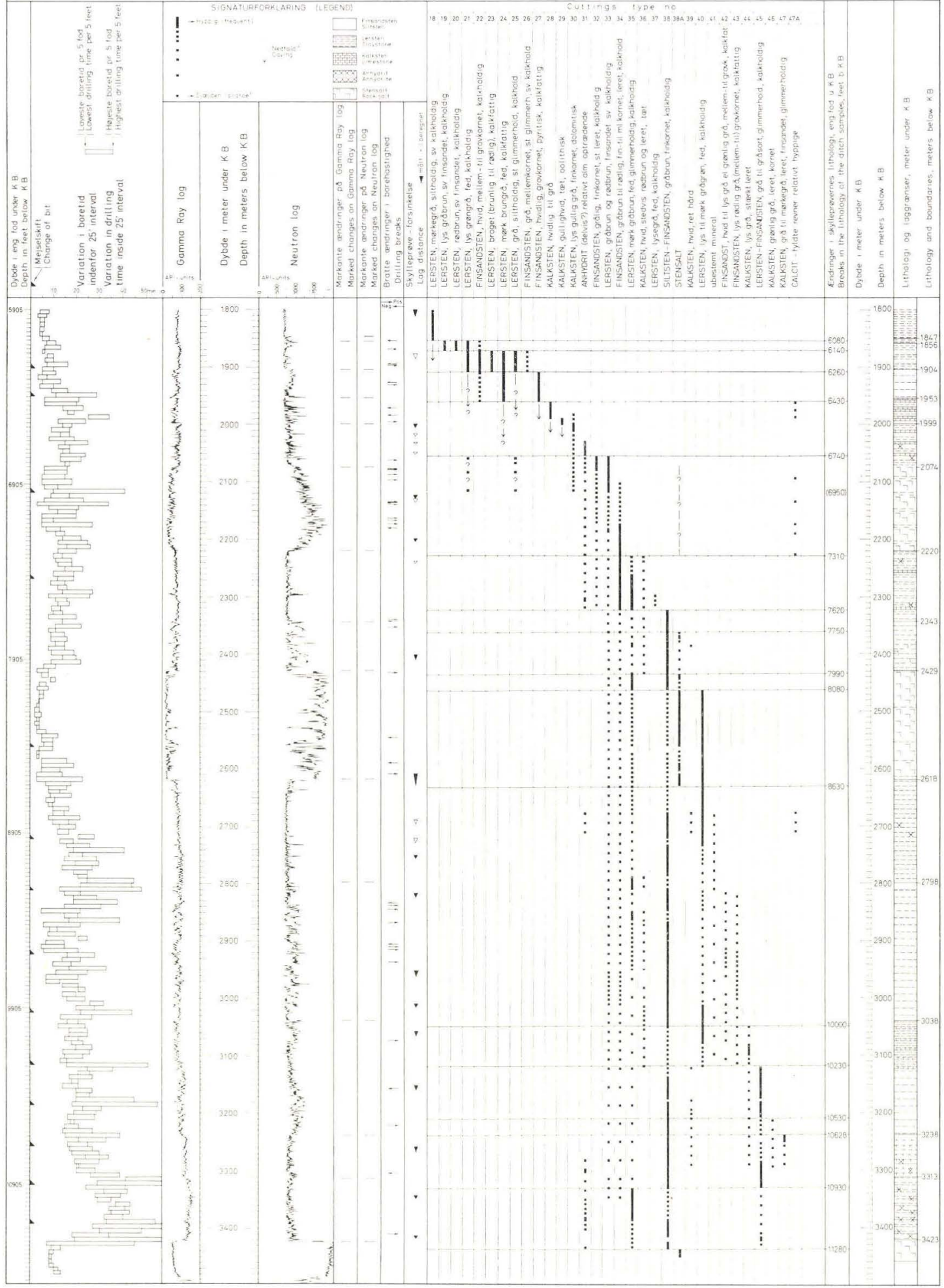

Fig. 23 
delsen, og at værdifulde, supplerende lithologiske oplysninger utvivlsomt vil kunne udledes af disse målinger.

Vedrørende begrebet »lag distance « henvises til omtalen under Rønde nr. 1 (DINESEN 1971, p. 33) samt til diagrammet for Nøvling nr. 1 (p. 13).

I det følgende er anvendt forkortelsen GR for gamma ray og $\mathrm{N}$ for neutron kurverne. Stigning og fald er aflæst ovenfra og nedefter. Alle dybder er angivet i forhold til kelly bushing (KB). Boredybder (herunder prøveudtagningsdybder) er målt i engelske fod. Schlumbergermålingerne er foretaget i meter systemet. Dybder sat med kursiverede typer er fremkommet ved en simpel omregning fra det ene målesystem til det andet.

\section{LITHOLOGISK BESKRIVELSE OG INDDELING}

( $\quad-1847 \mathrm{~m}\left(-6060^{\prime}\right)$ :

Lersten, mørkegrå, siltholdig (type 18).

Bemarkninger. Den mørkegrå lersten dominerer kraftig (90-95\% af cuttings) i skylleprøverne ned til 6080' $(1853 \mathrm{~m})$. Derunder er bjergarten fortsat almindelig, men den antages at være »nedfald «).

$1847-1856$ m $\left(6060^{\prime}-6089^{\prime}\right)$ :

Lersten, dels finsandet, gråbrun og rødbrun (type 19 og 20), dels fed, lys grøngrå (type 21), vekslende med finsandsten, hvid, mellem- til grovkornet (type 22).

Bemarkninger. I skylleprøvematerialet ses en lithologisk ændring ved 6080' $(1853 \mathrm{~m})$. En stigning på $\mathrm{N}$ kurven ved $1847 \mathrm{~m}$ hænger sandsynligvis sammen med ændringen, der antages at markere top af trias (top af rhaet).

$1856-1904$ m $\left(6089^{\prime}-6247^{\prime}\right)$ :

Lersten, dels fed, lys grøngrå og mørk brungrå (type 21 og 24), dels siltholdig, grå (type 25) vekslende med lersten, brunlig til rødlig (type 23) og med finsandsten, hvid til grå (type 22 og 26).

Bemarkninger. Der findes mindre udtalte ændringer på GR og N kurverne ved $1856 \mathrm{~m}$. Det lithologiske skift spores i skylleprøverne fra og med 6140' $(1871 \mathrm{~m})$.

$1904-1953$ m $\left(6247^{\prime}-6408^{\prime}\right)$ :

Finsandsten, hvidlig, grovkornet (type 27), vekslende med finere finsandsten som ovenfor (type 22) og med lersten (type 24).

Bemarkninger. Fald på GR og stigning på N kurverne ved 1904 m må antages at markere top af et afsnit med grovere sedimenter end ovenfor. Finsandsten (type 27) findes i skylleprøverne fra og med 6260' $(1908 \mathrm{~m}$ ). Forløbet af GR og $\mathrm{N}$ kurverne tyder på, at kornstørrelsen igen aftager mod afsnittets basis. 
$1953-1999$ m $\left(6408^{\prime}-6559^{\prime}\right)$ :

Kalksten, hvidlig til grå, stedvis gullig og i oolithisk udformning (type 28, 29 og 30), antagelig i veksling med lersten (især type 24).

Bemarkninger. Afsnittet er karakteriseret ved ret stærke udsving på GR og N kurverne. Det er sandsynligt, at minima på GR og maxima på N kurverne afspejler kalkstenslag. I skylleprøverne findes top for den kalkstensførende zone ved 6430' (1960 m).

1999-2074 m (6559'-6805'):

Lersten, dels som ovenfor (type 21, 24 og 25), dels gråbrun til rødbrun, finsandet (type 33), vekslende med lag af kalksten (type 30) og af finsandsten, grålig, finkornet, leret (type 32). Anhydrit synes almindelig fra 6650' (2027 m) og nedefter.

Bemarkninger. Afsnittet fremtræder som en enhed på GR kurven, der viser ret høje værdier tydende på lerbjergarter. Skylleprøverne er imidlertid præget af kalksten (type 30) helt ned til 6740' (2054 m), hvorfra lersten (type 33) og leret finsandsten (type 34) er registreret. De ovenfra kendte lertyper (21, 24 og 25) er kun til stede i små mængder, der er tolket som »nedfald «. Fra og med 6740' $(2054 \mathrm{~m})$ stiger andelen af to af typerne $(21 \mathrm{og} 25)$ igen, og fra denne dybde ned til 6950' $(2118 \mathrm{~m})$ er en primær tilstedeværelse i skylleprøverne formodet. I den foranstående tolkning af afsnittets lithologi er der lagt vægt på indikationerne fra GR kurven, således at en dominans af lersten gennem hele afsnittet er antaget.

2074-2220 m (6805'-7284'):

Stensalt vekslende med lersten, overvejende gråbrun til rødbrun (type 33), og finsandsten, grålig, leret (type 32), nedefter gråbrun til rødlig (type 34).

Bemarkninger. De lave værdier på GR og høje værdier på N kurven under 2074 m tyder på, at stensalt indgår som et betydningsfuldt element i lagserien. Skønt overgang til mættet saltmudder fandt sted inden for afsnittet ved 6950' $(2118 \mathrm{~m})$, er der dog ikke påvist stensaltkrystaller fra formationen i prøverne. Boretiderne svinger en del, hvilket bedst kan forklares ved at antage, at de lerstens- og finsandstensbjergarter, der optræder i prøverne, indgår i lagserien i veksling med stensaltet. Finsandsten (type 34) er ifølge radioaktivitetskurvernes forløb og de øgede boretider antagelig fremherskende ned mod afsnittets basis.

$2220-2343 \mathrm{~m}\left(7284^{\prime}-7687^{\prime}\right)$ :

Lersten, mørk gråbrun, oftest fed (type 35), sjældnere finsandet (type 33), vekslende med finsandsten (type $32 \mathrm{og}$ især 34 ), stedvis med mindre indslag af hvid til rødbrun kalksten (type 36). Nedefter optræder lersten, fed, lysegrå, og nederst muligvis siltsten til finsandsten, gråbrun (type 38). 
Bemarkninger. GR og N kurverne udviser henholdsvis en stigning og et fald ved $2220 \mathrm{~m}$, der antages at markere top af et lerstenspræget afsnit. Den mørke gråbrune lersten (type 35) findes i skylleprøverne fra og med 7310' $(2228 \mathrm{~m}$ ), og på samme dybde er noteret en ændring i mudderets farve og konsistens. Radioaktivitetskurverne viser kraftige udsving omkring 2296 m, antagelig svarende til større indslag af finsandsten. Siltsten til finsandsten (type 38), der præger det underliggende afsnit, optræder i prøverne allerede fra og med 7620' $(2323 \mathrm{~m})$.

\section{$2343-2429$ m $\left(7687^{\prime}-7969^{\prime}\right)$ :}

Siltsten til finsandsten gråbrun (type 38), stedvis af grovere karakter (type 34), vekslende med lersten (type 33 og 35), og muligvis med tynde lag af stensalt.

Bemarkninger. Under 2343 m findes ret kraftige udsving på GR og navnlig på N kurven, der tyder på voldsommere vekslinger i kornstørrelsen end ovenfor, sandsynligvis indgår også lag af stensalt, idet de første saltkrystaller, der antages at stamme fra formationen, er registreret fra og med 7750' $(2362 \mathrm{~m})$.

2429-2618 m $\left(7969^{\prime}-8589^{\prime}\right)$ :

Stensalt, med underordnede lag af lersten, øverst især mørk gråbrun (type 35), nedefter især grågrøn (type 40), og af siltsten til finsandsten (især type 38).

Bemarkninger. Både radioaktivitetskurvernes forløb (lave GR værdier, høje N værdier), de lave boretider og de mange stensaltkrystaller i prøverne fra 7990' $(2435 \mathrm{~m})$ og nedefter tyder på, at stensalt udgør en væsentlig bestanddel af dette afsnit. Den grågrønne lersten (type 40) dukker op i prøverne fra og med 8080' $(2463 \mathrm{~m})$, d.v.s. at den næppe optræder i afsnittets øverste del. At dømme efter nogle bratte stigninger i boretiden ned mod afsnittets basis findes her forholdsvis mere klastisk materiale end i den øvre del.

2618-2798 m (8589'-9180'):

Lersten, lys til mørk grågrøn, fed (type 40), vekslende med siltsten til finsandsten, gråbrun (type 38). Underordnet optræder finsandsten og lersten som ovenfor (type 33, 34 og 35), samt lidt kalksten (type 39).

Bemarkninger. Stigning på GR og fald på N kurverne ved 2618 m markerer en skarp grænse mod den stensaltførende formation ovenfor. De stærkere udsving på radioaktivitetskurverne, der især ses nedefter i det foreliggende afsnit, må antages at repræsentere finsandsprægede niveauer.

2798-3038 m $\left(9180^{\prime}-9967^{\prime}\right)$ :

Finsandsten, mellem- til grovkornet, dels hvid til lys grå eller grønlig grå (type 42), dels lys rødlig grå, vekslende med lersten og finsandsten som ovenfor (type 33, 34, 35, 38 og 40). Underordnet findes lidt kalksten (type 36).

Bemarkninger. Forløbet af GR og N kurverne, samt de svingende boretider 
(med mange bratte boretidsændringer) tyder på, at afsnittet er præget af stærkt varierende kornstørrelser. Noget grovere sedimenter gør sig kraftigere gældende end ovenfor og nedenunder, antagelig i form af finsandsten (type 42 og 43), der netop viser sig i skylleprøverne lidt under afsnittets top. Den nederste del af afsnittet synes dog at være præget af lersten (type 40).

3038-3238 m $\left(9967^{\prime}-10624^{\prime}\right)$ :

Lersten, overvejende grågrøn (type 40), gående over i kalksten, lys grå, stærkt leret (type 44), nedefter siltsten til finsandsten (type 38) og lersten til finsandsten, mørk grå (type 45).

Bemarkninger. Fordelingen af cuttings i skylleprøverne kunne tale for en opdeling af dette afsnit i et øvre leret, kalkrigere og et nedre stærkere finsandet underafsnit. Top for lersten til finsandsten (type 45) findes ved 10230' $(3118 \mathrm{~m})$, men på radioaktivitetskurverne ses ingen tydelig ændring ved (eller - på grund af »lag distance« - lidt over) denne dybde. Modstandskurve (laterolog) og lydhastighedskurve (sonic log) antyder, at der findes lithologiske ændringer indenfor afsnittet, men dybdeindikationerne på eventuelle grænser er ikke sammenfaldende.

3238-3313 m (10624'-10870'):

Lersten til finsandsten, mørk grå (type 45) og kalksten, leret og finsandet (type 47), vekslende med siltsten til finsandsten, gråbrun (type 38). Nedefter med øgede indslag af anhydrit.

Bemarkninger. En stigning på GR og et fald på N kurven ved 3238 m tyder på, at afsnittet er stærkere leret end det overliggende afsnit. Formationen er hårdere, hvilket medfører en hurtigere nedslidning af mejslen og hastigt voksende boretider.

3313-3423 m (10870'-11230'):

Lersten, mørk gråbrun, fed (type 35), vekslende med siltsten til finsandsten, gråbrun (type 38) og lersten til finsandsten, mørk grå (type 45). Anhydritindholdet er yderligere øget og udgør stedvis ca. $20 \%$ af cuttingsmængden.

Bemarkninger. Ved 3313 m ses en stigning på GR intensiteten, som antagelig markerer top af det nederste trias-afsnit, hvor en anhydritrig, fed lersten er fremherskende og medfører ret høje boretider. Nederst synes andelen af siltsten til finsandsten (type 38) dog igen at tiltage. Ved $3423 \mathrm{~m}$ ses et markant fald på GR og en stigning på N kurven, der sammen med fald i boretiden viser, at der påny bores i salt. Dette saltlag formodes at markere top af zechstein.

\section{KORRELATIONSMULIGHEDER}

Adskillige dybdeboringer i det nordlige Jylland (nord for Ringkøbing-Fyn aksen) er ført ned i triassiske aflejringer. Indenfor en nærmere afstand fra 
Nøvling nr. 1 foreligger oplysninger om større dele af trias-systemet fra Vinding nr. 1 (ca. 14 km mod NNV) og Gassum nr. 1 (ca. 85 km mod NØ) (SorGENFrEI \& Buch 1964), samt fra Rønde nr. 1 (ca. $107 \mathrm{~km}$ mod Ø) (Dinesen 1971).

Den forholdsvis korte afstand taget i betragtning skulle korrelationsmulighederne på forhånd synes bedst mellem Nøvling nr. 1 og Vinding nr. 1. Fra sidstnævnte boring, hvor kun det yngre trias (ned til ? muschelkalk) er gennemboret, savnes imidlertid Schlumbergermålinger, og det er ikke lykkedes at genkende stratigrafiske enheder, ældre end Vinding formationen (se BRUUN Christensen's afsnit, p. 132), fra den ene boring til den anden. Ifølge prøvebeskrivelserne i DANish American Prospecting CO's efterladte arkiv er saltaflejringer - som indtager betydelige mægtigheder i to zoner i Nøvlingboringen - fraværende i Vinding nr. 1. Det kan dog ikke udelukkes, at den manglende registrering af salt i Vinding-boringen skyldes anvendelsen af umættet boremudder.

Rønde nr. 1 er udført og registreret efter nogenlunde samme principper som Nøvling nr. 1. Mellem disse to boringer kan drages følgende sammenligninger:

$$
\begin{array}{cc}
\text { Rønde } n r . ~ & \text { Nøvling } n r . l \\
2614-2827 \mathrm{~m}(213 \mathrm{~m}) & 1847-1999 \mathrm{~m}(152 \mathrm{~m})
\end{array}
$$

Ifølge O. BRUUn CHRISTENSEN (1971, p. 90; nærværende rapport, p. 135) repræsenterer afsnittene sandsynligvis Gassum og Vinding formationerne med de dertil knyttede ostracod-zoner.

GR værdierne på den strækning, der omfatter den nedre del af Vinding formationen, (d.v.s. 2750-2827 m i Rønde nr. 1 og 1953-1999 m i Nøvling nr. 1) er lavere i Nøvling-boringen end i Rønde-boringen. Dette forhold stemmer overens med prøvebeskrivelserne, hvorefter indslagene af kalksten er kraftigere i Nøvling nr. 1 end i Rønde nr. 1.

$$
\begin{array}{cc}
\text { Rønde } n r .1 & \text { Nøvling } n r .1 \\
2827-2997 \mathrm{~m}(170 \mathrm{~m}) & 1999-2074 \mathrm{~m}(75 \mathrm{~m})
\end{array}
$$

Afsnittene er karakteriseret ved relativt høje GR værdier, og lagene består fortrinsvis af lersten og finsandsten. I den øvre del er grålige til grønlige farver fremherskende, mens rødlige til brunlige farver tager overhånd nedefter.

$$
\begin{gathered}
\text { Rønde } n r . ~ \\
\text { 2997-3178 m (181 m) }
\end{gathered}
$$

Nøvling $n r .1$ 2074-2220 m (146 m)

Afsnittene er karakteriseret ved lave GR værdier, der tyder på, at betydelige stensaltafsætninger optræder i begge boringer.

$$
\begin{gathered}
\text { Rønde } n r .1 \\
3178-3348 \text { m (170 m) }
\end{gathered}
$$

Nøvling $n r .1$ $2220-2429 \mathrm{~m}(209 \mathrm{~m})$

GR værdierne er relativt høje, dog med en tendens til at udsvingene er kraftigere 
nedefter end i den øvre del af afsnittene. Det kan tyde på, at indholdet af finsandsten øges nedefter i begge boringer på bekostning af lersten.

Rønde $n r .1$

$3348-3409 \mathrm{~m}(61 \mathrm{~m})$
Nøvling $n r, l$

2429-2618 m (189 m)

GR værdierne er lave, og lagene består overvejende af stensalt.

Rønde $n r .1$

3409-4643 m (1234 m)
Nøvling $n r .1$

2618-3423 m (805 m)

Indenfor disse afsnit, der udgør henholdsvis ca. $61 \%$ og ca. $51 \%$ af det samlede trias i Rønde nr. 1 og Nøvling nr. 1, har det ikke vist sig muligt at gennemføre korrelationer ved hjælp af Schlumberger-målingerne, og aflejringerne synes noget forskelligartede $\mathrm{i}$ de to boringer. Grovere sedimenter som sandsten er registreret $\mathrm{i}$ flere adskilte niveauer i Rønde-boringen men savnes i Nøvlingboringen, hvor til gengæld urene kalksten (typerne 44, 46 og 47) spiller en vis rolle.

Det er uafklaret, om de ovennævnte korrelationer kan tillægges chronostratigrafisk betydning. Den manglende persistens af begge eller et af saltlagene til henholdsvis Vinding nr. 1 og Gassum nr. 1 (se DinESEN, op. cit., p. 106), samt den relativt meget store mægtighed på det nedre saltlag i Nøvling nr. 1 tyder på stærk indflydelse af lokale forhold, og der er ingen sikkerhed for, at saltlagene i Nøvling nr. 1 og Rønde nr. 1 er parvis samtidige.

Det må antages, at de nederste godt $800 \mathrm{~m}$ af trias i Nøvling nr. 1 (2618$3423 \mathrm{~m}$ ) hovedsagelig repræsenterer buntsandstein. En nøjere afgrænsning af buntsandstein (evt. muschelkalk) og keuper kan ikke gennemføres på det foreliggende grundlag.

\section{ENGLISH SUMMARY \\ THE LITHOLOGY OF THE TRIASSIC SECTION IN NØVLING NO. 1}

The Triassic system comprises the beds between $1847 \mathrm{~m}$ and $3423 \mathrm{~m}$ below the Kelly Bushing. The distribution of 32 types of cuttings in about 450 ditch samples was studied by O. Michelsen and T. Juhl HANSEN. The description of the cuttings are given in Danish on fig, 23. The translations are as follows:

Type of cutting No.

\section{Lithology}

Claystone, dark grey, silty, slightly calcareous. light greyish brown, slightly silty, calcareous. reddish brown, slightly silty, calcareous. light greenish grey, sticky, calcareous.

Siltstone, whitish, medium to coarse grained, calcareous.

Claystone, varicoloured (brownish to reddish), non-calcareous. dark brownish grey, sticky, non-calcareous. 


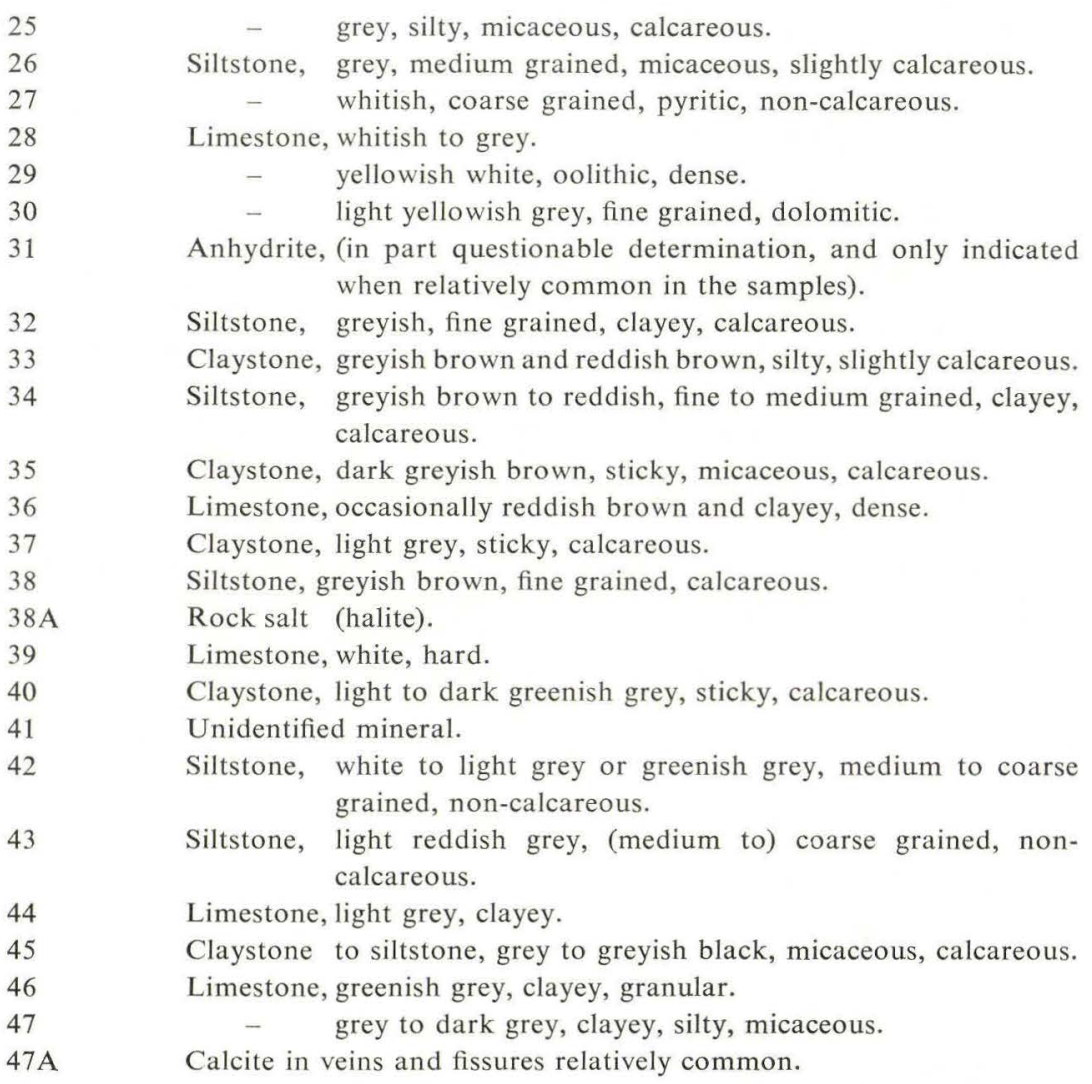

Because the last casing was set at $1070 \mathrm{~m}$, material from many different levels must be expected in all the samples, and it is hardly possible to get a precise lithostratigraphical insight. The subdivision given on pp. 138-141 (in abbreviated form p. 29) is based on drilling times, radioactivity logs, and lag distances, besides the lithologic descriptions.

The biostratigraphy of the uppermost $152 \mathrm{~m}$ is dealt with by O. BRUUN CHRISTENSEN (p. 135). No fossils were found below $1999 \mathrm{~m}$, and correlation of this part of the Triassic section (comprising Buntsandstein, (?) Muschelkalk, and Lower to Middle Keuper) must be done on a lithostratigraphical basis. A comparison with Rønde No. 1 (DINESEN 1971) gives the following results:

$$
\begin{gathered}
\text { Ronde No. } 1 \\
\text { 2614-2827 m (213 m) }
\end{gathered}
$$$$
\begin{aligned}
& \text { Novling No. } 1 \\
& 1847-1999 \mathrm{~m}(152 \mathrm{~m})
\end{aligned}
$$

According to O. BruUn Christensen (the present report, p. 135) these intervals represent the Vinding Formation with the associated zones of ostracodes.

In the Vinding Formation the gamma ray values are smaller in Nøvling No. 1 (1953$1999 \mathrm{~m})$ than in Rønde No. 1 (2750-2827 m). Possibly this is a consequence of larger intercalations of limestone in the Nøvling well than in the Rønde well, as indicated by the descriptions of the samples.

$$
\begin{array}{cc}
\text { Ronde No. } 1 & \text { Novling No. } 1 \\
2827-2997 \mathrm{~m}(170 \mathrm{~m}) & 1999-2074 \mathrm{~m}(75 \mathrm{~m})
\end{array}
$$


The sections are characterized by, relatively, high gamma ray values, and the beds consist predominantly of claystone and siltstone. Grey to greenish colours are prevailing in the upper part, and the lower part is dominated by reddish to brownish colours in both of the wells.

$$
\begin{array}{cc}
\text { Ronde No. } 1 & \text { Novling No. } 1 \\
2997-3178 \mathrm{~m}(181 \mathrm{~m}) & 2074-2220 \mathrm{~m}(146 \mathrm{~m})
\end{array}
$$

The sections are characterized by low gamma ray values, indicating deposits of rock salt in both of the wells.
Ronde No. 1
Novling No. 1
$3178-3348 \mathrm{~m}(170 \mathrm{~m})$
$2220-2429 \mathrm{~m}(209 \mathrm{~m})$

Relatively, the gamma ray values are high. In both of the wells there is a tendency for larger fluctuations of the curves downwards, indicating larger intercalations of siltstone in this lower part of the sections.
Ronde No. 1
$3348-3409 \mathrm{~m}(61 \mathrm{~m})$
Novling No. 1
2429-2618 m (189 m)

The gamma ray values are low, and the beds consist predominantly of rock salt.

$$
\begin{gathered}
\text { Ronde No. } 1 \\
\text { 3409-4643 m (1234 m) }
\end{gathered}
$$

$$
\begin{gathered}
\text { Novling No. } 1 \\
2618-3423 \mathrm{~m}(805 \mathrm{~m})
\end{gathered}
$$

No correlations have been practicable within these sections. Apparently, the sediments are coarser (sandstone) in some levels of the Rønde well, while limestones (of the types 44,46 , and 47) seem to be rather common in the Nøvling well.

No salt was observed in Vinding No. 1 (Sorgenfrei \& Buch 1964), and only one thicker bed of salt was recorded from Gassum No. 1 (DINESEN 1971). Therefore, it is an unsolved problem whether the two thicker beds of salt in Rønde No. 1 and Nøvling No. 1 are synchronous or not.

The boundaries between Bunter, Muschelkalk, and Keuper have not been fixed in Nøvling No. 1.

\section{LITTERATUR}

Dinesen, A., 1971. Trias i Rønde nr. 1. - Danm. Geol. Unders., III Rk., Nr. 39, pp. 94-107. København.

Sorgenfrei, Th. \& Buch, A., 1964. Deep Tests in Denmark 1935-1959. - Danm. Geol. Unders., III Rk., Nr. 36. København. 


\section{ZECHSTEIN I NØVLING NR. 1 \\ (3423-3534 M) \\ LITHOLOGISK BESKRIVELSE OG INDDELING}

af

Fritz Lyngsie Jacobsen

\section{INDLEDNING}

Ved beskrivelse af zechsteinbjergarterne er der, ligesom ved boringen Rønde nr. 1 (JACOBSEN 1971), foretaget en halvkvantitativ cuttingsanalyse. Denne analyse er foretaget dels af TORBEN JUUL HANSEN på borestedet og senere af forfatteren i laboratoriet. Den nedre del af afsnittet (3522-3534 m) er kærnet, hvilket gør det muligt at give en sikker beskrivelse for denne del.

De opborede cuttings er 1-5 mm store med den hyppigste størrelse omkring ca. $2 \mathrm{~mm}$. Ved den halvkvantitative analyse er der specielt arbejdet omhyggeligt i afsnittet med anhydrit og dolomit, for at sikre alle typer blev observeret. Alle de fundne cuttingstyper er mikroskoperet, og der er foretaget lysbrydningsbestemmelse af de enkelte mineraler.

Resultaterne af disse undersøgelser er sammenholdt med følgende målte logs: Gammastråling, neutron og lydhastighed. Disse er alle indtegnet på det medfølgende boreprofil (fig. 24, side 148).

\section{LITHOLOGISK BESKRIVELSE}

(Alle dybder er angivet i m under kelly bushing)

3423-3485 m: Stensalt, gråligt til klart og med enkelte rødlige typer i toppen af afsnittet. Anhydrit findes spredt dels som mindre finkornede klumper og slirer og dels som fri krystaller, der er max. $2 \mathrm{~mm}$ lange og findes indesluttet $\mathrm{i}$ stensaltet. Der er ikke set spor efter $\mathrm{K}-\mathrm{og} \mathrm{Mg}$ mineraler, ligesom de målte logs ikke tyder på, at sådanne er til stede. De på fig. 24 indtegnede gammastråling, neutron og lydhastigheds-logs viser desuden, at saltet er homogent med kun små mængder urenheder.

3485-3501 m: Anhydrit, grålig til hvid, finkornet og med enkelte tynde lerslirer. I anhydriten, der er karakteriseret af lave gammastråleværdier og høje lydhastighedsværdier, findes et lerlag ved 3490-3492 m, hvor de modsatte forhold gør sig galdende. Leret er gråsort, siltholdigt og med et lille indhold af finkornet dolomit. 
3501-3524 m: Dolomit, gråbrune, brune og lysebrune typer findes. De gråbrune og brune typer findes $\mathrm{i}$ hovedparten af afsnittet, medens de lysebrune findes $\mathrm{i}$ den nedre del hvor gammastrålingskurven viser en aftagen. Alle dolomittyperne er tætte og består af 10-30 $\mu$ store uregelmæssigt begrænsede dolomitkrystaller. Bjergarterne indeholder desuden en varierende mængde ler og spredte kvartskorn af siltstørrelse. De nederste 1,6 $\mathrm{m}$ af afsnittet er kærnet og er beskrevet nedenfor.

3524-3534 m: Anhydrit-dolomit-bjergart. Anhydriten er finkornet, hvid til lys blålig og dolomiten tæt, gråbrun til brun, dog ret lys. Hele afsnittet er kærnet, og en mere detailleret beskrivelse findes nedenfor.

\section{Karnebeskrivelse}

Beskrivelse af afsnittet $0-13,7 \mathrm{~m}\left(0-45^{\prime}\right)$ af kærne 1: 11555'-11613' (3522,0$3539,6 \mathrm{~m})$. Kærnens sande dybde er, efter korrektion $\mathrm{i}$ forhold til de målte Schlumberger logs, $11550^{\prime}-11608^{\prime}$.

0-1,6 m: Dolomit, lys gråbrun til brun, tæt, stedvis lysere i uregelmæssige partier. Styloliter findes spredt i hele afsnittet med varierende retning og hældning. Bjergarten består af max. $50 \mu$-almindeligvis 10-30 $\mu$-store dolomitkrystaller med uregelmæssig overflade. Spredt findes sub-euhedrale anhydritkrystaller. Leret, der findes i styloliterne er sortbrunt og findes sammen med enkelte kvartssiltkorn og noget organisk materiale.

1,6-2,0 m: Anhydrit-dolomit-bjergart. Grænsen mod den overliggende dolomit er en stylolit med sortbrunt ler, medens den nedefter er mere gradvis. Anhydriten danner ofte cumulusagtige strukturer mellem hvilke dolomiten findes. Dolomiten er af samme type som ovenfor og anhydriten som den underliggende type.

2,0-4,3 m: Anhydrit, hvid til blålighvid, mellemkornet (1-4 mm store krystaller) med 0-2 cm mægtige uregelmæssige dolomitiske gråbrune til brune lag. Dolomiten findes desuden som uregelmæssige, ofte diffuse, slirer. Indholdet af dolomit er ca. $10 \%$ i afsnittet.

4,3-9,1 m: Anhydrit-dolomit-bjergart, uregelmæssigt lagdelt af blålighvid til hvid mellemkornet anhydrit og af gråbrun til brun tæt dolomit ofte dannende diffuse lag. Sammen med dolomiten træffes ofte 1-5 mm mægtige sortbrune lerlag med organisk materiale og kvartssiltkorn. Dolomitindholdet er ca. $25 \%$. 9,1-13,4 m: Anhydrit-dolomit-bjergart med en diffus uregelmæssig lagdeling, hældende ca. $30-40^{\circ}$ og med spredte tynde brunsorte lerlag. Ved ca. 9,9-10,2 m relativt mere anhydrit, ellers ca. $40 \%$ dolomit. Dolomiten bliver nedefter gradvis mørkere fra gråbrun til mørk gråbrun, forårsaget af et stigende indhold af ler og organisk materiale. Anhydriten bliver også noget mere mørkfarvet.

13,4-13,7 m: Dolomit, mørk gråbrun, tæt, nederst udviklet som konglomerat. De enkelte knolde består af samme type dolomit som udgør mellemmassen. 


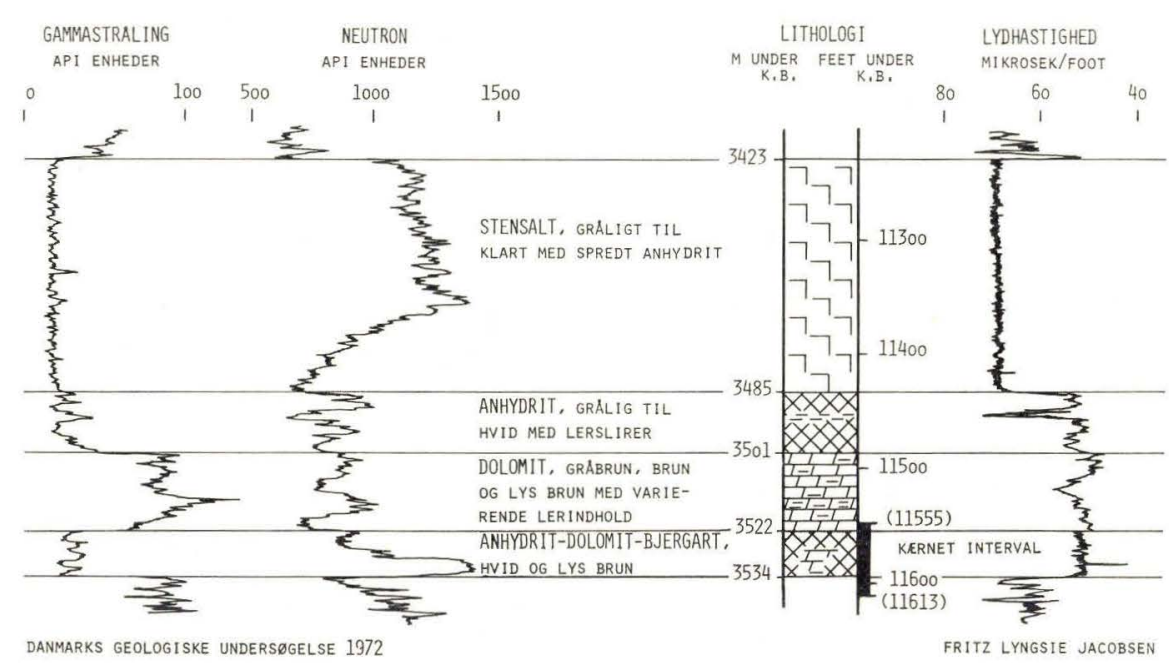

Fig. 24. Profil af zechstein-afsnittet med gammastråling-, neutron- og lydhastighedslog indtegnet. På venstre side af profilsøjlen er dybden af de enkelte bjergartsafsnit angivet og på højre side findes dybdeangivelse $\mathrm{i}$ fod ligesom det kærnede interval er indtegnet. Alle dybder er angivet fra Kelly Bushing.

\section{SAMMENFATNING}

De i denne boring trufne anhydriter og dolomiter har alle tydelig karakter af at være randfacies bjergarter (RICHTER-BERNBURG 1955 og BRAITSCH 1962) og er alle aflejret i den samme cyklus. Dette er også i overensstemmelse med seismiske data (BAARTMAN, side 34), hvor det vises, at bjergarterne tynder ud mod S. Samme forhold træffes også $\mathrm{S}$ for Ringkøbing-Fyn højderyggen i boringen Arnum nr. 1, hvor anhydriterne og dolomiten er henført til C4, C3 og D4 (SORGENFREI og BUCH 1964) og hvor C antages at svare til den tyske Stassfurtcyklus.

Anhydriterne og dolomiten i Nøvlingboringen synes at udgøre en enhed, selvom der findes et mindre lerlag ved 3590-3592 m. Den type bjergart træffes dog også i anhydrit-dolomit-serien, som adskiller de ældste og de ældre salte i det nordjyske sænkningsområde, og kan ikke anvendes som et kriterium på en adskillelse i forskellige cykler. Alle de gennemborede zechsteinaflejringer anses for at høre til den ældre cyklus, som afsluttes med Veggerby kalizone (JACOBSEN 1971). Dette begrundes med manglen på de sorte bituminøse skifre og de dolomitiske kalksten der er truffet i Røndeboringen og med ligheden der er mellem dele af anhydrit-dolomit-serien og de i denne boring fundne anhydriter og dolomiter. 
ENGLISH SUMMARY

\section{ZECHSTEIN IN NØVLING NO. 1}

The description is based on a semi-quantitative cuttings analysis and a cored part of the well, both of which have been compared with the Schlumberger logs (fig. 24, p. 148).

Lithologic profile of the evaporites in the Zechstein:

3423-3485 m: Rock salt, greyish to clear with some reddish salt at top. All types of salt contain anhydrite, disseminated and as aggregates.

3485-3501 m: Anhydrite, greyish to white, fine-grained and with thin streaks of clay.

3501-3522 m: Dolomite, greyish brown, brown to light brown, dense. Stylolites common in the cored part (the profile is cored from $3520 \mathrm{~m}$ to bottom).

3522-3534 m: Anhydrite-dolomite-rock. The anhydrite (about $75 \%$ of the total) is bluish to white, fine-grained. The dolomite is light greyish brown to light brown, dense. The lowermost $0.3 \mathrm{~m}$ is a conglomerate of dolomite, dark greyish brown.

It is found possible to correlate the whole evaporite section in this well with the older cycle which in the central part of the evaporite area ends with the Veggerby Potassium Zone.

\section{LITTERATUR}

BRAITSCH, O., 1962. Entstehung und Stoffbestand der Salzlagerstätten. - Springer-Verlag. JACobsen, F. L., 1971. Zechstein i Rønde nr. 1. - Danm. geol. Unders. III Rk., Nr. 39. Richter-Bernburg, G., 1955. Über salinare Sedimentation. - Z. deutsch. geol. Ges. Band 105,4 , Teil.

Sorgenfrei, T. \& Buch, A., 1964. Deep Tests in Denmark 1935-59. - Danm. geol. Unders. III Rk., Nr. 36. 


\section{RØNDE OG NØVLING FORMATIONERNE (SILUR) I NØVLING NR. 1 \\ (3534-3762 M) \\ af}

\section{Ole Bruun Christensen}

Hertil tavle 6-7

INDLEDNING

En række lithologiske og palæontologiske træk af præ-zechstein aflejringerne fra boringen Nøvling nr. 1 er tidligere blevet beskrevet (BRUUN CHRISTENSEN 1971 a). Desuden er aflejringer ved anden lejlighed blevet inddelt lithostratigrafisk i en øvre Nøvling formation og en nedre Rønde formation (BRUUN Christensen $1971 \mathrm{~b}$ ).

I det efterfølgende opsummerer forfatteren ovennævnte beskrivelser og supplerer disse med enkelte nyere iagttagelser foretaget ved senere vurderinger af materialet. En række tektoniske data fra borehullet er frembragt og sammenstillet af SVEND E. HeNRiksen (side 54). De vulkanske bjergarter er især blevet studeret af FRITZ LYNGSIE JACOBSEN (side 162), og forfatteren har sammen med denne sammenstillet fig. 25 på basis af prøvebeskrivelser og Schlumberger målinger. Forfatteren har på tavlerne 6-7 forsøgt ved fotografier at demonstrere de forskelligartede sedimentstrukturer, som især Nøvling formationen er rig på.

\section{NØVLING FORMATIONEN}

Denne formation er defineret ved et profil i boringen Nøvling nr. 1 fra 11599' til 12200' (3534-3719 m) umiddelbart over Rønde formationen. Formationen er ca. 160 meter tyk og består af vekslende lag af basalter og grå til rødbrune lersten og finsandsten med indslag af kalksten. Foruden skylleprøver er der fra boreintervallet frembragt tre borekærner og femten intakte prøver fra borehullets sider (BRUUN CHRISTENSEN 1971 a).

I modsætning til den underliggende Rønde formation består Nøvling formationen af hårde vekslende aflejringer, der er aflejret $\mathrm{i}$ et miljø med højt energi niveau. Talrige strukturer i sedimenterne viser urolige bundforhold i aflejringstidsrummet. De forskellige sedimenter veksellejrer hyppigt eller findes som indeslutninger i hinanden. Fra de tre kærner i intervallet har forfatteren søgt at illustrere disse træk med tavlerne 6-7.

I boringen Nøvling nr. 1 viser en sandsynlig svag vinkeldiskordans i den 


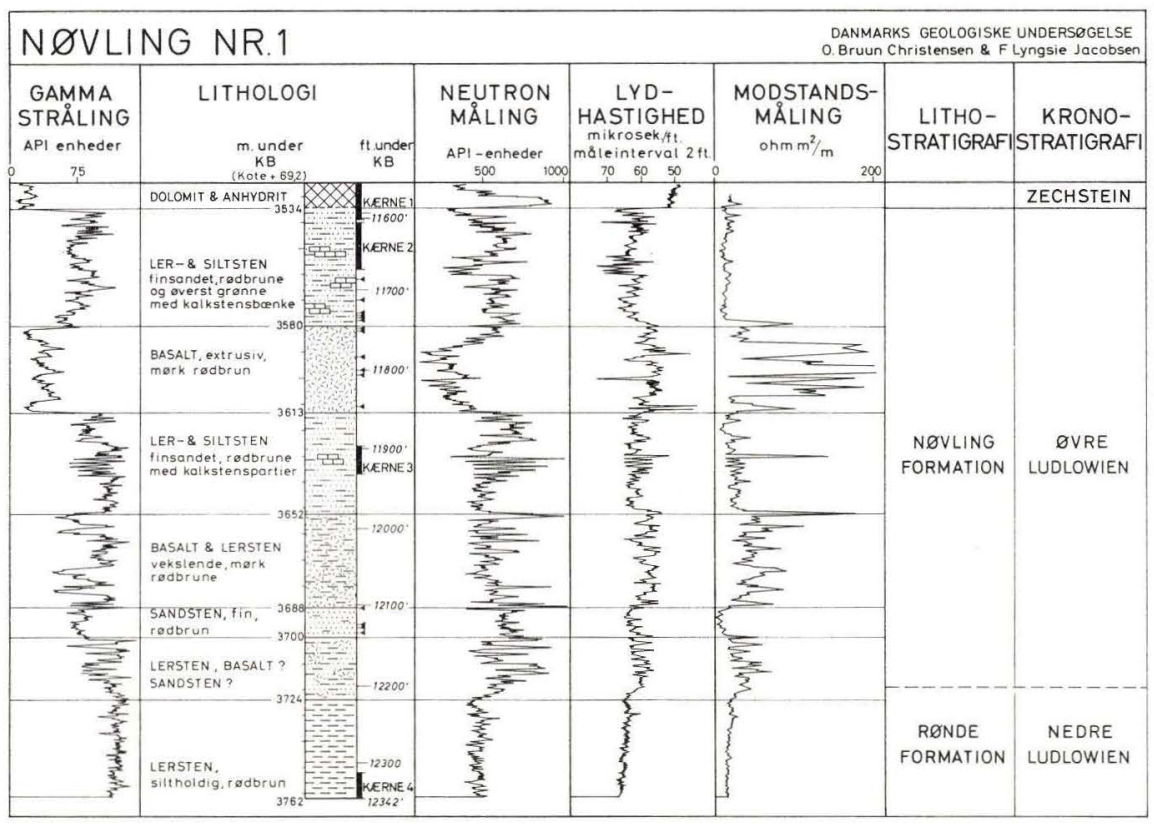

Fig. 25

nederste del af Nøvling formationen sig ved, at borehullets retning begynder at skifte ved dybden 3700 meter (cf. HenriKsEn side 54 og fig. 10). Aflejringerne umiddelbart under denne sandsynlige vinkeldiskordans i Nøvling nr. 1 kan ligesom i Rønde nr. 1 vanskeligt interpreteres på basis af Schlumberger kurver og skylleprøvematerialet. Dette boreafsnit (3700-3724 meter) har tidligere været beskrevet som bestående af vulkanitter under den foreløbige tolkning af Schlumberger kurverne og på grund af det næsten monotypiske indhold af basalt i skylleprøverne (BRUUN CHRISTENSEN 1971 a). Der er imidlertid næppe tvivl om forekomster af lermaterialer i dette boreinterval. Desuden viser kurverne (fig. 25) hårde partier med lave gammastrålingsværdier og stor elektrisk modstand. Det store indhold af basaltisk materiale i skylleprøverne og mangel på andre hårde bjergartsfragmenter, ud over meget lidt finsandsten, synes at antyde tilstedeværelse af basalt og måske finsandsten i nogle lag. Disse bjergarter kunne eventuelt være af detrital oprindelse. Imidlertid har det ikke været muligt i dette aflejringsled at iagttage andre retningsforandringer af borehullet end den fastlagte (Henriksen, side 54) ved 3700 meter. Grænsen mellem Rønde formationen og Nøvling formationen findes i denne aflejring.

En vurdering af aflejringernes hældning er tilvejebragt ved studier af borekærnerne, ved beregninger af borehullets skiftende retninger og ved sammenligninger med de hældningsmålinger, der blev foretaget direkte i borehullet (HENRIKSEN, side 54). Det fremgår heraf, at der umiddelbart over den tilsyneladende svage vinkeldiskordans mod Rønde formationen i Nøvling formationen 
findes laghældninger på ca. $35^{\circ} \bmod \varnothing \mathrm{N} \varnothing$ og som op gennem formationen tilsyneladende jævnt ændres til laghældninger på ca. $32^{\circ} \bmod N \varnothing$. Drejning af hældningsretningen er bemærkelsesværdig derved, at hældning og hældningsretning efter aflejringen af Nøvling formationen bliver meget nær den, hvori Rønde formationen befinder sig i Nøvling nr. 1. Meget afvigende måleresultater i nogle lag skyldes sandsynligvis målinger af primære og sekundære sprækkedannelsers retninger.

\section{Afgrcensning og lejringsforhold}

Den øvre afgrænsning af formationen med en tydelig vinkeldiskordans og konklomeratiske dannelser mod zechstein dolomit fremtræder tydeligt i borekærnematerialet. Den nedre grænse for formationen er vanskeligere at fastlægge på basis af bjergartsmaterialet fra borehullet, skønt disse viser en tydelig forskel mellem den ensartede og relativt bløde Rønde formation og de uensartede og relativt hårde aflejringer i Nøvling formationen.

En diskordans, som med stor sandsynlighed synes at være tilstede ved toppen af Rønde formationen i Rønde nr. 1 synes med nogen usikkerhed at kunne overføres på aflejringerne i Nøvling nr. 1. Overgangen mellem Rønde og Nøvling formationerne i de to boringer synes at have nogen lighed, skønt en sikker lithologisk tolkning af dette afsnit endnu ikke er tilvejebragt (LyNGSIE JACOBSEN 1971, side 118, fig. 15).

I boringen Rønde nr. 1 synes der at være lokaliseret en diskordans mellem Rønde og Nøvling formationerne ved basis af et boreinterval med basaltaflejringer. Den øverste del af Rønde formationen umiddelbart under denne diskordans synes ifølge Schlumbergerkurverne at være af en noget andet sammensætning end den nedre del, hvori en borekærne er udtaget (LYNGSIE JACOBSEN 1971 fig. 15).

Radiometriske aldersmålinger af de øverste basalter i Nøvling formationen har vist alderen $276 \pm 12$ millioner år (LARSEN 1972). Denne alder svare til perm perioden og er for lav. En lang række målinger på palæozoiske aflejringer fra danske dybdeboringer viser for lave aldre og antyder, at aflejringerne sandsynligvis gennem tektoniske påvirkninger er svagt omdannede.

Den regionale udbredelse af de vulkanske bjergarter i Nøvling formationen bør ligeledes sammenholdes med tyngdekortene for området (f.eks. i SoRGENFREI \& BUCH 1964). Et dybtliggende legeme af vulkansk oprindelse og basisk eller ultrabasisk sammensætning kan forklare udbredelsen af det ekstremt høje tyngdemaksima fra området ved Nøvling og ud under Århus Bugten. Den østsydøstlige retning svarer nøje til udbredelsen af vulkanitterne og til retningen af det øvre siluriske Sydbaltiske Bassin i øvrigt. Over dette store midtjydske magma- eller vulkanområde måles et tyngdemaksima med højere værdier, end der er lokaliseret over den højtbeliggende Ringkøbing-Fyn Højderyg syd derfor, og som geologisk er mere markant, men består af væsentlig lettere materialer. 


\section{Lithostratigrafisk underdeling}

Over den sandsynlige diskordans ved 3700 meter kan formationen underdeles i seks led. Mindst tre led indeholder basalter og lejlighedsvis lersten. Over og mellem disse led findes led af ler- og finsandsten, hvoraf de øverste især indeholder mere eller mindre veludviklede kalkstenslag, der ofte er dolomitiserede. Disse veksellejrede led dominerer formationen og har næsten samme tykkelser. I nederste led over den mulige vinkeldiskordans ved 3700 meter, hvor borehullet begynder at skifte retning, findes et ca. 10 meter svagt leret finsandstenslag.

Nøvling formationens øverste led (3534-3580 m) er ca. 40 meter tyk og består af vekslende lag af oftest finsandede og skifrede lersten og finsandsten i grålige og rødbrune - øverst grønne - farver. Mindre kalkstensbænke og dolomitiske partier er almindelige. Den øverste del af leddet kendes gennem borekærnerne 1 og 2. Den nederste del af leddet lokaliseres foruden på Schlumberger kurver tillige ved skylleprøver og intakte prøver fra borehullets sider (side-wall samples) udtaget efter boringens udførelse.

Næstøverste led i Nøvling formationen (3580-3613 m) udgøres af basaltbænke med en samlet tykkelse på ca. 30 meter. Den lithologiske beskrivelse og tolkning af disse iøvrigt ekstrusive og noget forvitrede basalter foretages af LYNGSIE JACOBSEN (side 162). En række intakte prøver fra borehullets sider er udtaget i dette led.

Det tredieøverste led, beliggende mellem basalter i den mellemste del af Nøvling formationen, omfatter en lagrække af rødbrune finsandede lersten og finsandsten (3613-3652 m) med en tykkelse på ca. 35 meter. Leddet synes noget mere finsandet end det øverste led i formationen, ligesom kalkstenspartierne i dette led ikke er så almindelige. Borekærne 3 er udtaget midt i dette led.

Et led, sandsynligvis bestående af vekslende lag af basalt og lersten, kan lokaliseres i den nedre del af formationen (3652-3688 m) med en tykkelse på ca. 30 meter. Leddet kan kun interpreteres på basis af Schlumberger kurver og skylleprøverne. Disse sidste består næsten udelukkende af basaltfragmenter i det pågældende boreafsnit. De hårde lag i leddet kan derfor næppe være andet end basalt, mens bløde aflejringer med høje gammastrålingsværdier kan tolkes som lersten. Bjergartsfragmenterne i skylleprøverne afviger ikke fra tilsvarende bjergartsfragmenter i højere boreafsnit.

Næstnederst $\mathrm{i}$ formationen findes et led (3688-3700 m), på ca. 10 meters tykkelse, bestående af sandsten og finsandsten med rødbrune farver og med et svagt lerindhold. En række intakte prøver fra borehullets sider supplerer skylleprøvematerialet. Målinger har vist, at borehullet udvidedes ret kraftigt på dette sted med ret kraftig nedfald af finsandsten til følge.

Det nederste led i Nøvling formationen (3700-3724 m) er vanskelig at identificere og beskrive lithologisk. Det synes at være af en heterogen sammensætning indeholdende lersten sandsynligvis med basalt og sandsten. Leddet danner 
overgang mellem Rønde formationen og Nøvling formationen og synes at indeholde de svage vinkeldiskordanser. Dette overgangsled kan være tilstede i boringen Rønde nr. 1 delvis som toppen af Rønde formationen.

\section{Palcontologiske forhold}

I formationens tre borekærner (fig. 25) er der fundet mange fossiler (BRUUN Christensen 1971 a). Disse kunne bestemmes til at være af øvre ludlovien alder og synes facielt at kunne tilhøre et skaldyrs-miljø i modsætning til Rønde formationen, der facielt synes at tilhøre et graptolit-miljø. Disse er begge velkendte silurisk miljøer. Graptolit-miljøet var udviklet i et dybere og roligere havområde end skaldyrs-miljøet.

Bevaringstilstanden af fossilerne i Nøvling formationen er ret forskellig i de forskellige sedimenter. Skalmaterialet er oftest omkrystalliseret. I finsandstenene kan skalmaterialet være opløst og replaceret af hæmatit.

Molluskerne er repræsenteret ved orthoceratiter og enkelte, sandsynligvis tykskallede gastropoder. Crinoider og trilobitfragmenter er ligeledes repræsenteret ved enkelte fund, mens tentaculiter synes ret almindelige gennem fund af slægten Tentaculites med flere arter.

Af coelenterater er der fundet en del rester efter rugose koraller og en velbevaret conularie, der sandsynligvis kan henføres til slægten Paraconularia.

Brachiopoder udgør den største del af fossilerne. Disse er alle articulate og repræsenteres at orthide, strophomenide og rhynchonellide typer. Arten Chamarotoechia nucula (Sowerby) synes i nogle afsnit at være meget almindelig.

Af de fossiler, der har størst betydning for biostratigrafiske inddelinger af palæozoiske aflejringer, kan nævnes conodonter. Disse er for Nøvling formationens vedkommende blevet undersøgt af TORBEN JuUl Hansen, hvis undersøgelser er anført side 158.

Ostracoder er en anden gruppe fossiler, der har stor stratigrafisk betydning. Disse er fundet $\mathrm{i}$ alle tre borekærner fra formationen og viser, at formationen tilhører øvre ludlovien. Følgende former kan nævnes: Neobeyrichia sp. sp., Nodibeyrichia sp., Juviella sp., Beyrichia sp., Calcaribeyrichia aff. C. bicalcarata MARTINSON 1962 og muligvis Hoburgiella sp.

\section{RØNDE FORMATIONEN}

Den originale lithostratigrafiske definition til profil i boringen Rønde nr. 1 (BRUUn Christensen 1971 b):

»Overvejende rødbrune lersten med en tilsyneladende mægtighed på 73 meter og omfatter sandsynligvis tillige de underliggende basaltaflejringer, hvori boringen er standset. Formationens nedre grænse er dog ikke mulig at fastlægge. Såfremt basalt og lersten fortsætter veksellejrende, må formatio- 
nens nedre grænse søges under boringens slutdybde. Formationens øvre grænse findes ved basis af de overliggende basaltaflejringer, hvori der i Rønde nr. 1 muligvis findes en vinkeldiskordans. «

I Rønde nr. 1 blev der udtaget en borekærne fra dette interval med en svag siltholdig, svag skifret, rødbrun og lejlighedsvis grønliggrå lersten. Kærne nr. 4 i Nøvling nr. 1 svarer i lithologisk henseende helt til materialet fra Rønde nr. 1, så vidt det kan ses ved en umiddelbar sammenligning af kærnestykker.

\section{Lithostratigrafiske afgransninger}

Fra 3724 meter til borehullets bund ved 3762 meter fremviser Schlumberger kurverne et så ensartet forløb, at aflejringerne ingen steder i denne målte del af Rønde formationen afviger væsentlig fra borekærnen i lithologisk henseende. Formationens nedre begrænsning er dog ikke kendt. I Rønde nr. 1 dannes den nedre grænse enten af en basaltbænk, eller også er der indlejret basaltaflejringer i formationen. Er Rønde formationen tilstede i Slagelse nr. 1, er den her uden indslag af basaltiske materialer. I Nøvling nr. 1 er Rønde formationen uden basaltbænke i de øverste ca. 35 meter, der er kendt i boringen.

Undersøgelserne af borekærnens hældninger, borehullets retning og hældningsmålinger i Nøvling nr. 1 af HENRIKSEN (side 54) viser laghældninger af Rønde formationen på ca. $30^{\circ} \mathrm{i}$ en $ø$ stlig retning. Kalkspatfyldte sprækkedannelser i borekærnen har en næsten lodret retning.

\section{Biostratigrafi}

Fund af Monograptus colonus (BARRANDE) i den øvre del af borekærne 4 tillader korrelation med nilssoni-scanicus zonen i nedre ludlovien. Desuden viser såvel fossilet som sedimentet, at sedimentationen har fundet sted i et betydeligt roligere miljø end det, hvori Nøvling formationen blev dannet. Formationen indeholder kun meget små mængder kalk udenfor de kalkspatfyldte sprækker. Fossiler, som kun er fundet i den aller øverste del af borekærnen, findes næsten udelukkende som aftryk. Foruden pelecypoder er der fundet et eksemplar af Tentaculites sp. og enkelte eksemplarer af ostracoder (BRUUn CHRISTEnSEN 1971 a).

\section{KONKLUSION}

Rønde formationen, som er defineret i boringen Rønde nr. 1 (BRUUN CHRISTENSEN 1971 b), er dannet som svagt skifrede og svagt finsandede lersten i et relativt roligt miljø. Formationen udgør de nederste 40 meter af boringen Nøvling nr. 1. Fund af Monograptus colonus angiver alderen nedre ludlovien.

Nøvling formationen er defineret i boringen Nøvling nr. 1 (BRUUN CHRI- 
STENSEN 1971 b) umiddelbart over Rønde formationen. Overgangen mellem de to formationer er vanskelig at udrede i detailler, idet grovklastiske aflejringer synes at være tilstede såvel over som under en sandsynlig vinkeldiskordans mellem formationerne.

Nøvling formationen er aflejret i miljøer med højt energi niveau. Aflejringerne er ca. 160 meter mægtige. Over diskordansen følger et mindre led af lerede finsandsten. Den øvrige del af formationen kan underdeles i fire næsten lige tykke led af extrusive basalter veksellejrende med grå til rødbrune lersten og finsandsten med indslag af kalksten. En meget varierende fauna fra skaldyrmiljøer henfører formationen til øvre ludlovien.

ENGLISH SUMMARY

THE RøNDE AND NØVLING FORMATIONS (SILURIAN) IN NØVLING NO. 1

The Rønde Formation has been established in the boring Rønde No. 1 (BRUUN CHrISTENSEN 1971 b). It is throughout a shaly and slightly silty claystone deposit from a relatively quiet environment. The lowermost 40 metres of the boring Nøvling No. 1 are in this Formation. Monograptus colonus from the upper beds indicates a Lower Ludlovian Age.

The Nøvling Formation has been established in the boring Nøvling No. 1 (BRUUN Christensen 1971 b) above the Rønde Formation. The boundary between the two formations is difficult to fix more closely (fig. 25). Clastic materials are present mostly above a probably disconformity between the two formations. A member closely connected with the disconformity probably includes clay, basalt and sandstones.

The Nøvling Formation is deposited in a high energy environment. It is about 160 metres thick. Above the disconformity there is a rather thin member consisting of clayish siltstone. The remaining part of the Formation has been subdivided into four members of nearly equal thickness. These members consist of extensive basalt beds alternating with greyish to reddish brown claystones and siltstones with a few beds of limestone. A rich shelly fauna classifies the formation in the Upper Ludlovien.

The regional extent of the volcanic rocks of the Nøvling Formation may explain the presence of a very high gravity anomaly situated in the deepest part of the South Baltic Basin, extending from the Nøvling area to the Ârhus Bay. A deep body of heavy material, perhaps in the deeper bedrock, may be the source to the volcanic rocks found in the borings Rønde No. 1 and Nøvling No. 1. The anomaly may be explained as well by an assumption of enormous extrusives in the Upper Silurian beds, centering in central Jylland. High values of gravity have been measured farther to the south, too, over the Ringkøbing-Fyn High, but the high Pre-Zechstein non-sedimentary bedrocks there consist of rather light material, and relatively smaller gravity values have been measured.

\section{LITTERATUR}

Christensen, O. BruUn, 1971 a: Øvre silur i dybdeboringen Nøvling nr. 1. (English Summary). - Danmarks Geologiske Undersøgelse, Rapport nr. 7, pp. 24. - København. Christensen, O. BRUUn, $1971 \mathrm{~b}$ : Den stratigrafiske inddeling af præ-zechstein aflejringerne i Rønde nr. 1. (English Summary). - Danmarks Geologiske Undersøgelse, III. række nr. 39, pp. 119-123. - København. 
Jacobsen, F. Lyngsie, 1971: De dybeste lag i Rønde nr. 1 (4873-5300 m). Lithologisk beskrivelse og inddeling. (English Summary). - Danmarks Geologiske Undersøgelse, III. række nr. 39, pp. 114-118. - København.

LARSEN, O., 1972: Kalium/Argon datering af prøver fra danske dybdeboringer. - Dansk geol. Foren., Årsskrift for 1971, pp. 91-94. - København.

Sorgenfrei, Th. \& Buch, A., 1964: Deep Tests in Denmark 1935-1959. - Danmarks Geologiske Undersøgelse, III. række nr. 36. - København. 


\section{CONODONTER FRA DE SILURISKE LAG \\ I NØVLING NR. 1}

af

\section{Torben Juul Hansen}

Hertil tavle 8

Der er undersøgt fire prøver fra Nøvling nr. 1; men kun en prøve fra kærne nr. 1, 52' under dens top havde så stort et kalkindhold, at en delvis nedbrydning bl.a. i kogende $\mathrm{CH}_{3} \mathrm{COOH}$ var mulig.

De tre øvrige prøver blev uden resultat overfladeundersøgt efter knusning. Det drejer sig om følgende rødbrune lerstensprøver:

Kærne nr. 4

FAUNA

Hindeodella BASSLER 1925.

Hindeodella equidentata RHODES 1953. $\frac{1}{2}^{\prime}$ under toppen

$17^{\prime}-18^{\prime}-\quad-$

$27^{\prime}-\quad-$

1953: Hindeodella equidentata n. sp. - RhODEs, s. 303.

1957: $\quad$ - $\quad$ RHODES - WALliser, s. 34.

1958: $\quad$ - $\quad$ RHODES - KOCKEL, s. 258.

1960: $\quad$ - RHODES - ZIEGLER, s. 182.

1960: Hindeodella cf. H. equidentata RHODES - WALLISER, s. 30.

1962: Hindeodella equidentata RHODES - ETHINGTON + FURNISH, s. 1267.

1962: - $\quad$ RHODES - WALliSER, s. 282.

1964: - - RHODES - WALLISER, s. 36.

Antal: 1 (3?).

Bemarkninger: Selvom den forreste proces næsten mangler fuldstændig, anses bestemmelsen for sikker, da arten er meget konstant og karakteristisk ved på den bageste proces at have frie dentikler, der bagud bliver stadig større, forhold der tydeligt ses på det fundne eksemplar.

To andre fragmenter hører sandsynligvis til denne art, der indenfor slægten Hindeodella regnes for primitiv, dels på grund af den veludviklede basalkavitet, og dels på grund af den manglende alternation og/eller sammensmeltning af dentikler på den bageste proces, der karakteriserer de fleste postsilure repræsentanter. 
Geografisk udbredelse: England, Tyskland, Böhmen, Østrig, Karniske alper, Bulgarien, Algeriet, Marokko, Spanien og Canada.
? Lonchodina BASSLER 1925.
M. silur - ø. perm.
Lonchodina ? greilingi WALLISER 1957.
M. silur. - n. devon.

1957: Lonchodina greilingi n. sp. - WALLISER, s. 38.

1958: Lonchodina greilingi WALLISER - KOCKEL, s. 258, 259.

1960: - - WALLISER - WALLiser, s. 31.

1960: - WALLISER - ZIEGLER, s. 188.

1962: - - WALLiser - Ethington og Furnish, s. 1274.

1962: - WALLISER - WALLISER, s. 283.

1964: - - WALLISER - WALLISER, S. 44.

Antal: 2 (3?)

Bemarkninger: De to symmetriske eksemplarer er ufuldstændigt bevarede, men viser begge den i artsbeskrivelsen omtalte karakteristiske modsatte krumning af processerne i det vandrette plan. At der alligevel må tages forbehold i slægtsbestemmelsen skyldes artens store variation i forbindelse med placeringen som overgangsform til Trichonocella inconstans (WALLISER 1957), Synprioniodina silurica (WALLISER 1964) og forløbere for slægten Plectospathodus (BRANSON og Mehl 1933). Et tredie fragment hører mest sandsynlig til denne samme art, men mangler den ene proces og kan ikke bestemmes med sikkerhed.

Geografisk udbredelse: Tyskland, Spanien, Karniske alper, Marokko, Algeriet og Canada.

Lonchodina aff. walliseri ZIEGLER $1960 . \quad$ N. ludlow - n. devon.

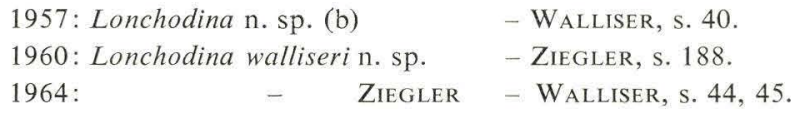

Antal: 1 .

Bemarkninger: Det fundne eksemplar har karaktertræk, for eksempel en skarp for- og bagkant på hovedtanden, der udelukker andre beskrevne arter i denne slægt, men mangler tilsyneladende på den anden side den længdeløbende fortykkelse på indersiden af den bageste proces, der som oftest ses afbildet. Et par fragmenter har præg af det samme tilhørsforhold. Der er muligvis tale om en ny art.

Geografisk udbredelse: L. walliseri er fundet i Tyskland, Böhmen, Karniske alper og Spanien.

Ozarcodina Branson og Mehl $1933 . \quad$ M. ord. - m. trias.

Ozarcodina sp.

Antal: 1 . 
Bemarkninger: På grund af den ufuldstændige bevaringstilstand kan fragmentet ikke artsbestemmes.

Geografisk udbredelse: Slægten er kosmopolitisk.

Plectospathodus Branson og MehL, $1933 . \quad$ N. silur. - n. devon.

Plectospathodus extensus RHOdes $1953 . \quad$ N. ludlow - n. devon.

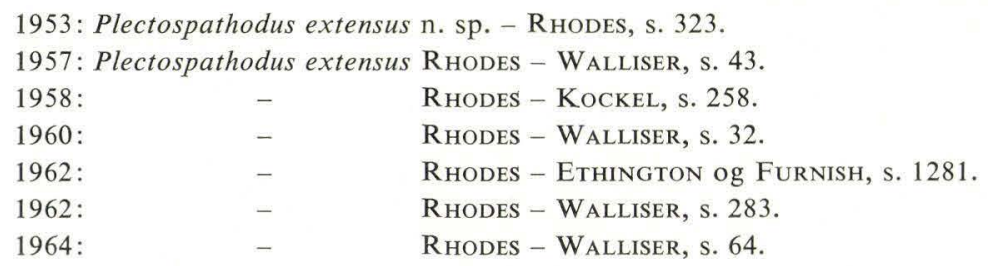

Antal: 1.

Bemarkninger: Det fundne eksemplar er velbevaret, og bestemmelsen regnes for sikker, selvom arten har mange variable karaktertræk f.eks. med hensyn til basalgrubens udformning og processernes relative krumning.

Geografisk udbredelse: England, Tyskland, Østrig, Böhmen, Karniske alper, Serbien, Spanien, Marokko, Algeriet og Canada.

? Spathognathodus Branson og MeHL 1941. M. ord. - m. trias.

? Spathognathodus sp.

Antal: 1.

Bemæerkninger: Det fundne fragment består af 10 dentikler anbragt vinkelret på en høj, sammentrykt proces. Da det ikke med sikkerhed kan afgøres, om der har existeret en hovedtand, kan slægten Ozarcodina ikke udelukkes i bestemmelsen.

Geografisk udbredelse: Slægten Spathognathodus er kosmopolitisk.

\section{STRATIGRAFISK PLACERING}

Den stratigrafiske alder kan ikke sættes mere nøjagtig end til tidsrummet imellem n. ludlow - gedinnian, idet egentlige ledefossiler mangler. Det skal nævnes at BISCHOFF og SANNEMANN i 1958 omtaler arterne Hindeodella equidentata og Plectospathodus cf. extensus fra en transgressionshorisont over m. ludlow kalksten, Frankenwald. Alderen angives at være ? siegennian, men senere forfattere har anset disse former som værende udtryk for en afsætning på sekundært leje.

Resultatet af den her foreliggende undersøgelse bekræfter og ligger i forlængelse af de konklusioner OLE BRUUN CHRISTENSEN på grundlag af andre fossilfund er nået frem til (se side 150-157). 
ENGLISH SUMMARY

\section{CONODONTS FROM THE SILURIAN OF NøVLING NO. 1}

Four samples from the Nøvling boring were examined for conodonts. Only one of these samples proved to be calcareous enough to be decomposed by boiling in $\mathrm{CH}_{3} \mathrm{COOH}$. This sample was taken from core No. $1,52^{\prime}$ below its top.

A total of 6 more or less identifiable species of conodonts were found: Hindeodella equidentata RHODES, ? Lonchodina greilingi WALLISER, Lonchodina aff. walliseri ZIEGLER, Ozarcodina sp., Plectospathodus extensus RHodes, and? Spathognathodus sp. They are all pictured in plate 8 .

The two conodonts which could be determined to species are previously known from the time interval Ludlovian to Lower Devonian. The other species mentioned are found within the time span Ordovician to Triassic. They are all known from the Ludlovian, and this fact corresponds with the conclusion made by OLE BRUUN CHRISTENSEN in his article pp. $150-157$, that the most probable age of the beds in core No. 1 is Upper Silurian.

\section{LITTERATUR}

Bischoff, G. \& SANnemann, D., 1958. Unterdevonische Conodonten aus dem Frankenwald. - Notizbl. hess. L.-Amt Bodenforsch., V86, pp. 87-110.

Branson, E. B. \& Mehl, M. G., 1933. Conodont studies No. 1 og 2. - Univ. Missouri Studies, V8, pp. 168-259.

Ethington, R. L. \& Furnish, W. M., 1962. Silurian and Devonian conodonts from Spanish Sahara. - Journ. Pal. V. 36, pp. 1253-1290.

Kockel, F., 1958. Conodonten aus dem Paläozoikum von Málaga (Spanien). - N. Vb. Geol. Paläont., Mh., 1958, pp. 255-262.

Rhodes, F. H. T., 1953. Some British Lower Palaeozoic conodont faunas. - Phil. Trans. Roy. Soc. London. V. 237, pp. 261-334.

Walliser, O. H., 1957. Conodonten aus dem oberen Gotlandium Deutschlands und der Karnischen Alpen. - Notizbl. hess. L.-Amt Bodenforsch., V85, pp. 28-52.

- 1960. Scolecodonts, Conodonts and Vertebrates, in: Boucut, A. J. and others: A late Silurian fauna from the Southerland River formation, Devon Island, Canadian Arctic, Archipelago. - Bull. V. 65. Geol. Surv. Canada X, 51 pp.

- 1962. Conodontenchronologie des Silurs (= Gotlandiums) und des tieferen Devons mit besonderer Berücksichtigung der Formationsgrenze. - Symposiumsband z. internat. Arbeitstagung Silur-Devon Bonn-Bruxelles 1960, pp. 281-287.

Ziegler, W., 1960. Conodonten aus dem Rheinischen Unterdevon (Gedinnium) des Remscheider Sattels (Rheinisches Schiefergebirge). - Paläont. Z., V34, pp. 169-201. 


\title{
VULKANITERNE I DE PRÆ-PERMISKE LAG I NØVLING NR. 1
}

\author{
af
}

\section{Fritz Lyngsie Jacobsen}

I de præ-zechsteine bjergarter, som er beskrevet af OLE BRUUN CHRISTENSEN (p. 150), indgår dels afsnit, der med sikkerhed kan identificeres som basalt og dels afsnit hvor en sådan identifikation er mere tvivlsom, men hvor det anses for sandsynligt, at der indgår basalt. Fastlæggelsen af de enkelte basaltafsnits grænser er baseret på et studium af følgende målte logs: Gammastråling, neutron, modstandsmåling og lydhastighedsmåling (fig. 25, p. 151). Den petrografiske undersøgelse er udført på materiale, der dels er opboret som cuttings (1-2 mm store) og dels optaget som »junk basket«-prøve.

Afsnittet 3580-3613 m består af en mørk rødbrun extrusiv finkornet porfyritisk basalt, der er kraftigt opsprækket i varierende retninger. At basalten er kraftigt opsprækket ses af neutron- og modstandsmålingerne, hvor den store variation i de målte værdier viser, at der findes varierende vandmængder i bjergarten. HenriKSEN (p. 54) har desuden vist, at der er stor variation i de målte hældninger i dette afsnit.

I afsnittet 3652-3688 $\mathrm{m}$ træffes som ovenfor mørk-rødbrun extrusiv finkornet porfyritisk basalt. Opsprækningen er mindre i dette afsnit og der findes desuden spredte lerlag som tydeligt afslører sig på gammastrålingloggen, hvor der er lag med en højere gammaintensitet.

Afsnittet $3700-3724 \mathrm{~m}$ viser stor variation og består sandsynligvis af en heterogen aflejring af basalt, lersten, sandsten og/eller tuf-bjergarter. Disse to sidste vil give næsten samme udslag på de målte logs. Alle bjergarterne er rødbrune, de finkornede mørke, de lidt grovere kornede lidt lysere.

De mikroskoperede basalter er alle kraftigt forvitret, og grundmassen er omdannet til et mørkt næsten opakt aggregat, hvor det ikke er muligt at se strukturer (fig. 26, p. 163). Plagioklasen viser kun nogen omdannelse til et sericitlignende mineral. Texturen er porfyritisk, ofitisk med porfyroblaster, der er 2-7 mm store. Plagioklasen i den ofitiske grundmasse er 0,1-0,4 $\mathrm{mm}$ lange og ca. $1 / 5$ så brede. Porfyroblasterne har et anorthitindhold på $60-65 \%$ og med en ca. $25 \mu$ mægtig randzone med et An-indhold på ca. $50 \%$. Samme forhold gør sig gældende for plagioglas-listerne hvor de ligeledes centralt har 60-65\% An og i en ca. $25 \mu$ randzone har ca. $50 \%$ An. Der er yderligere fundet små mængder ikke bestemmelig pyroxen og som accessorisk mineral apatit. 


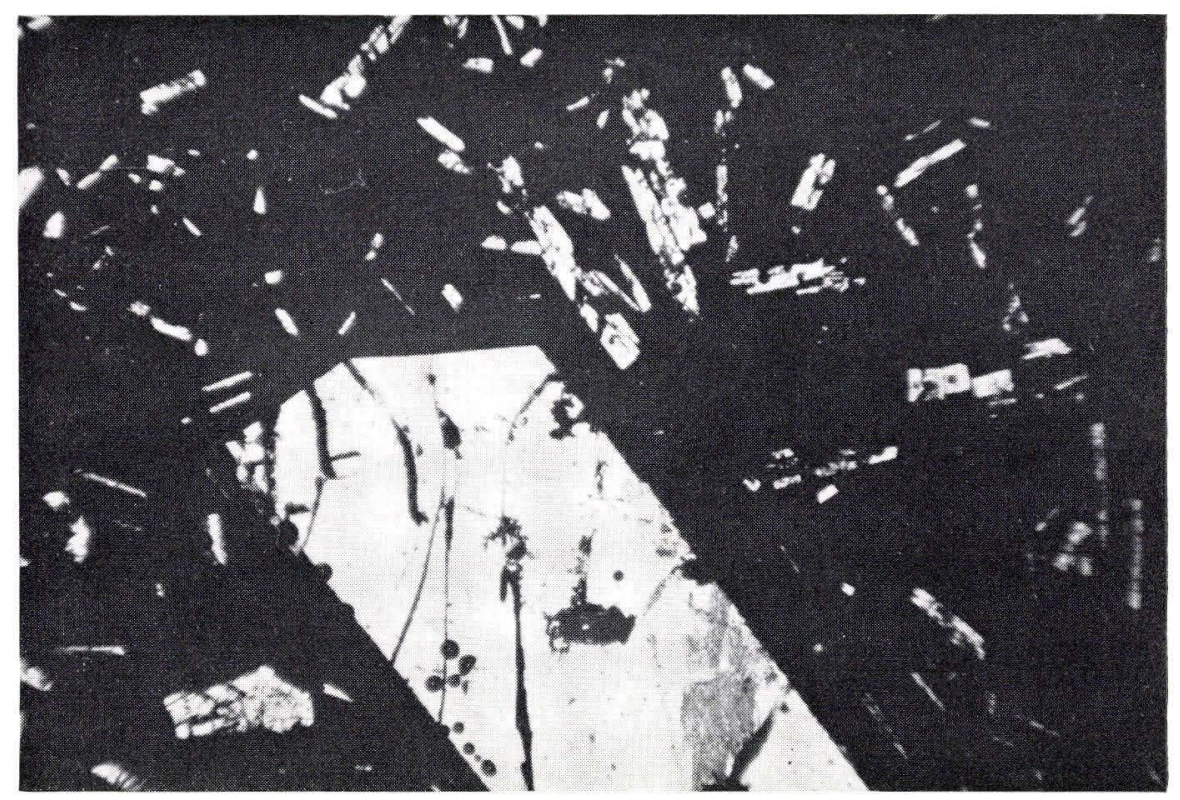

Fig. 26. Basalt fra junk basket prøve $11.745^{\prime}-11.749^{\prime}(3579,9-3581,1 \mathrm{~m}) 7$ ox. 1 nicol. I den centrale del af billedet ses en plagioklasporfyroblast med et seritiseret parti. De mindre plagioklaslister ses indesluttet i den næsten opake grundmasse.

Det fremgår klart af mikroskoperingsresultaterne, at basalten er extrusiv på grund af den hurtige afkøling, men det er ikke muligt at afgøre om det er egentlige flow's eller tuffer. På grund af den kraftige forvitring må bjergarterne have været udsat for påvirkning af iltholdigt vand.

Alderen af basalterne er bestemt dels ved en Kalium/Argon undersøgelse og giver en alder på $276 \pm 12$ mill. år (OLE LARSEN 1971), og den palæontologiske alder der er øvre ludlowien (Ole BRUUn Christensen p. 150). Ole Larsen anser som det sandsynligste, at der har været en mindre regional opvarmning i perm, som har forårsaget den lavere alder af det undersøgte materiale.

ENGLISH SUMMARY

\section{THE VOLCANITES IN THE PRE-PERMIAN BEDS OF NOVLING NO. 1}

In the depth-intervals: $3580-3613 \mathrm{~m}, 3652-3688 \mathrm{~m}$ and $3700-3724 \mathrm{~m}$ (fig. 25 , p. 151) the boring passes through basalts which are extrusive, dark reddish brown, porphyritic and ophitic, and have an An-content of $60-65 \%$ in the plagioclase. All of the plagioclase grains have a $25 \mu \mathrm{rim}$ with an An-content of about $50 \%$. The groundmass is nearly opaque (fig. 26, p. 163). In the section 3652-3688 $\mathrm{m}$ there are a few beds of claystone and in the section 3700-3724 m several beds of claystone are observed. A kalium/argon age-determina- 
tion gives $276 \pm 12$ million years (OLE LARSEN 1971), and a palaeontological determination gives Upper Ludlowien (Ole BruUn Christensen, p. 150). Ole Larsen believes the lower age to be caused by a smaller regional rise of the temperature during the Permian.

\section{LITTERATUR}

LARSEN, OLE, 1971. K/Ar datering af prøver fra danske dybdeboringer. Dansk geol. Foren. Årsskrift 1971. 
TAVLER

PLATES 


\section{TAVLE 1}

Gamborg-fauna, selandien (paleocæn), Nøvling nr. 1.

Fig. 1 a-b: Globigerina danica BANG, nr. 715201, interval 1710'-1740' (532-540 m)

Fig. 1 a: Dorsalsiden, $\times 200$.

Fig. 1 b: Detalje af sidste kammer, $\times 665$.

Fig. 2a-d: Subbotina triloculinoides (Plummer), nr. 572501, interval 1650'-1680 (503$512 \mathrm{~m})$.

Fig. 2a: Dorsalsiden, $\times 200$.

Fig. $2 \mathrm{~b}$ : Detalje, $\times 665$.

Fig. 2c: Detalje af sidste kammer, $\times 665$.

Fig. 2d: Detalje af sidste kammer, $\times 2000$.

\section{PLATE 1}

Gamborg-fauna, Selandian (Paleocene), Nøvling No. 1.

Figs. $1 \mathrm{a}-\mathrm{b}$ : Globigerina danica BANG, No. 715201, interval 1710'-1740' (532-540 m).

Fig. 1 a: Dorsal view, $\times 200$.

Fig. $1 \mathrm{~b}$ : Detail of last chamber, $\times 665$.

Figs. 2a-d: Subbotina triloculinoides (Plummer), No. 572501, interval 1650'-1680' (503$512 \mathrm{~m})$.

Fig. 2a: Dorsal view, $\times 200$.

Fig. 2 b: Detail, $\times 665$.

Fig. 2c: Detail of last chamber, $\times 665$.

Fig. 2d: Detail of last chamber, $\times 2000$.

Mikrofotografierne på tavle 1-5 er udført på et Jeolco JSM-S1 scanning electronmikroskop. Fotoarbejdet er udført af O. NeERGaArd RASMusSen.

The scanning electron micrographs (pl. 1-5) have been taken by a Jeol JSM-S1.

The darkroom work is done by O. NEERGAARD RASMUSSEN. 

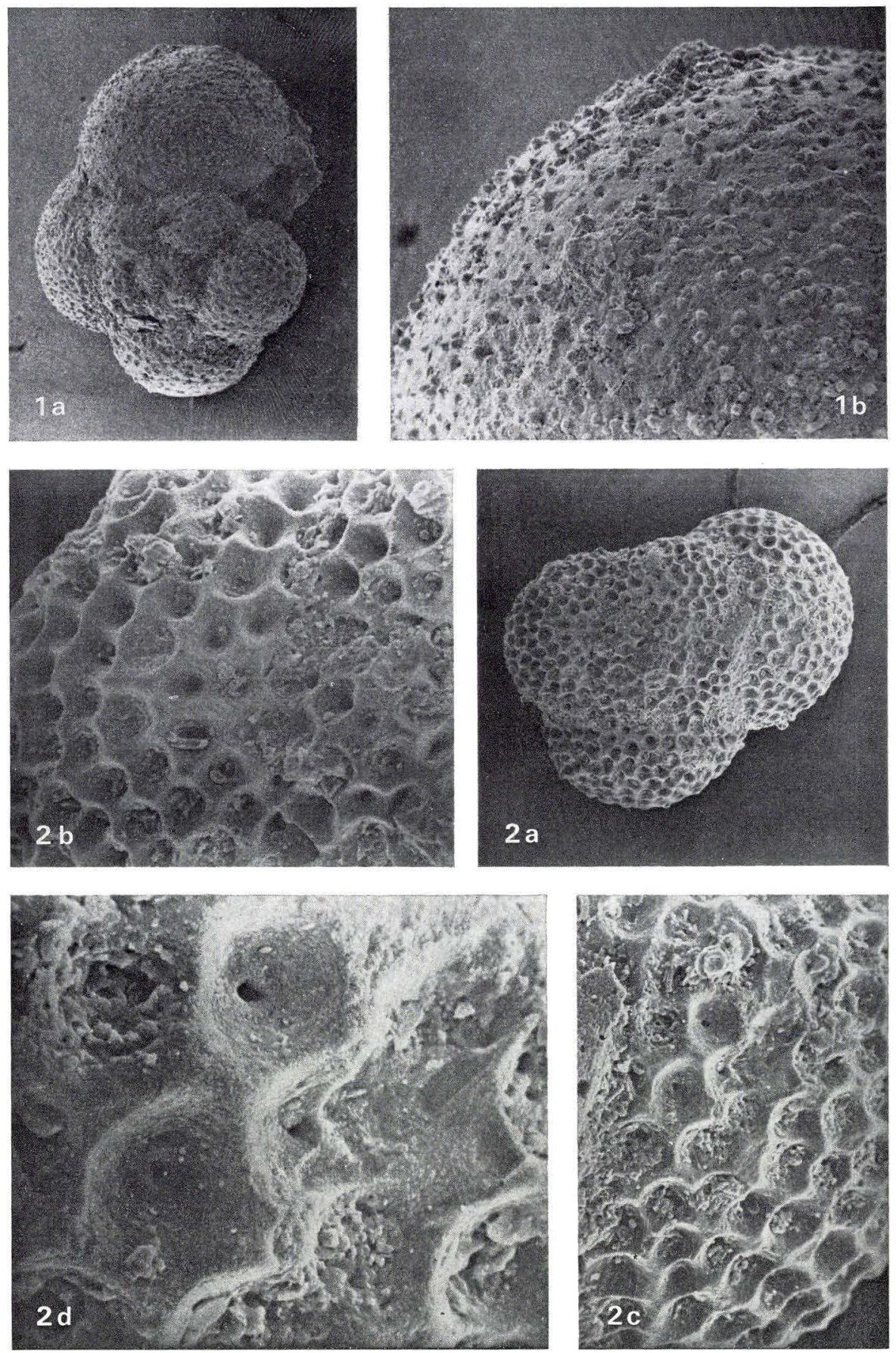
TAVLE 2

Gamborg-fauna, selandien (paleocæn), Nøvling nr. 1.

Fig. 3a-b: Globigerina danica BANG, nr. 572804, interval 1650'-1680' (503-512 m).

Fig. 3a: Set dorsalt - lateralt, $\times 200$.

Fig. 3b: Detalje af aperturregionen med en radiolar.

Fig. 4: Globigerina danica BANG, nr. 572806, interval 1650'-1680' (503-512 m), × 265 .

Fig. 5a-c: Globigerina danica BANG, nr. 715102, interval 1710'-1740' $(521-530 \mathrm{~m})$.

Fig. 5a: Set dorsalt, $\times 265$.

Fig. 5 b: Detalje af skaloverfladen på sidste kammer, $\times 800$.

Fig. 5c: Detalje af skaloverfladen på sidste kammer, med en coccolith, $\times 1333$.

\section{PLATE 2}

Gamborg-fauna, Selandian (Paleocene), Nøvling No. 1.

Figs. 3 a-b: Globigerina danica BANG, No. 572804, interval 1650'-1680' (503-512 m).

Fig. 3 a: Dorsally - laterally view, $\times 200$.

Fig. 3 b: Detail of the aperture-region with a radiolarian.

Fig. 4: Globigerina danica BANG, No. 572806, interval 1650'-1680' (503-512 m), ×265

Figs. 5a-c: Globigerina danica BANG, No. 715102, interval 1710'-1740' (521-530 m).

Fig. 5a: Dorsally view, $\times 265$.

Fig. 5 b: Detail of the external surface of last chamber, $\times 800$.

Fig. 5c: Detail of the external surface of last chamber, with a coccolith, $\times 1333$. 

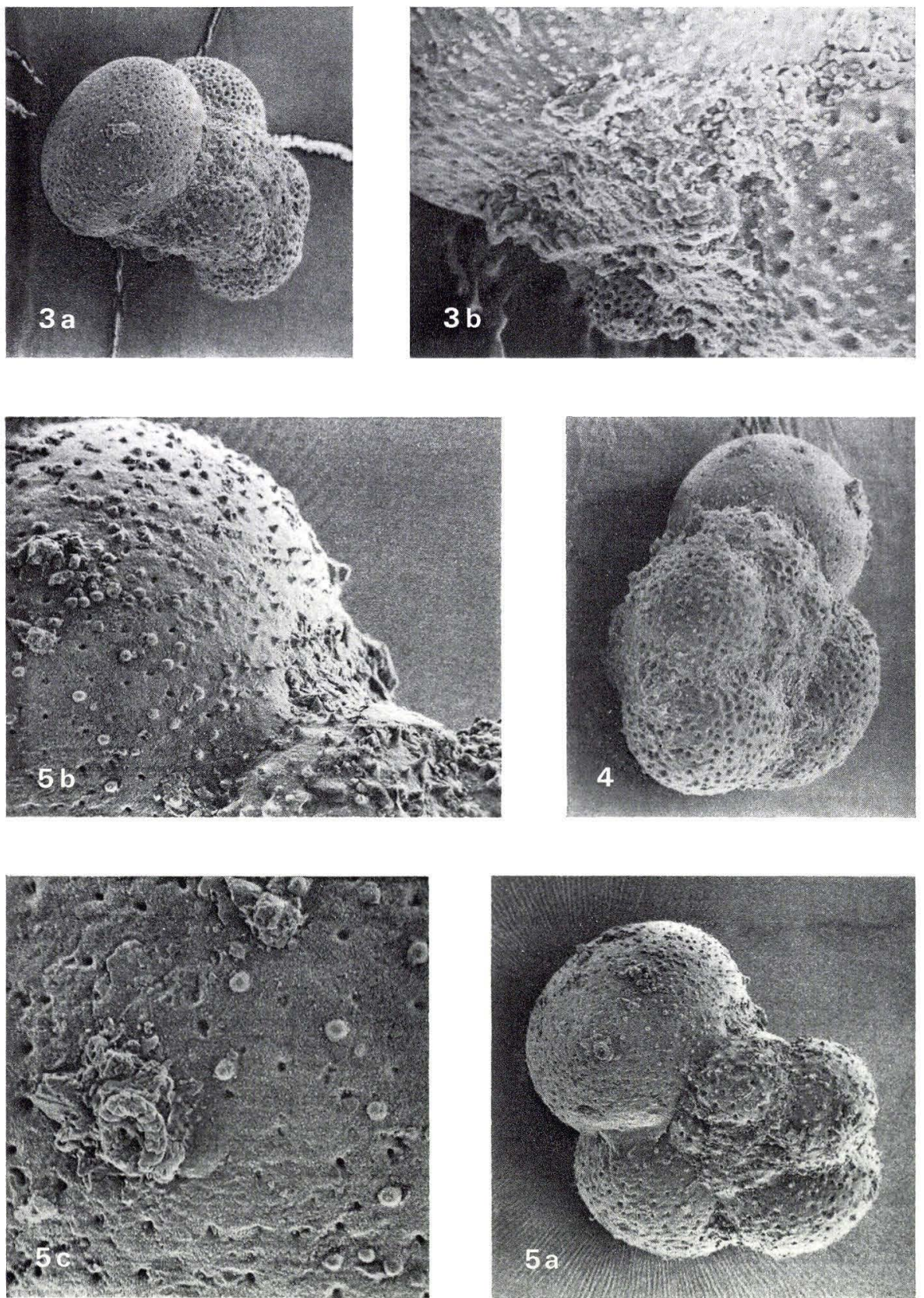
Øvre jura, Nøvling nr. 1.

Fig. 1 a-b: Lenticulina sp. ex 110-gruppen, nr. 796403 interval, 5010'-5040'. Fig. 1 a: $\times 200$.

Fig. 1b: Detalje af apertur, $\times 665$.

Fig. 2a-b: Planularia mariae KuzNETSOvA, nr. 776807, interval 4920'-4950'.

Fig. 2a: $\times 135$.

Fig. 2b: Detalje af apertur, $\times 665$.

Fig. 3: Reinholdella sp., nr. 684303, interval 5090'-5120', ventralsiden, $\times 135$.

Fig. 4: Lenticulina sp. 110, nr. 634311, interval 5690'-5705', × 135 .

Fig. 5: Saracenaria sp. 3, nr. 776805, interval 4920'-4950', set fra aperturet, $\times 100$.

\section{PLATE 3}

Upper Jurassic, Nøvling No. 1.

Figs. $1 \mathrm{a}-\mathrm{b}$ : Lenticulina sp. ex 110-group, No. 796403, interval 5010'-5040'.

Fig. $1 \mathrm{a}: \times 200$.

Fig. 2b: Detail of aperture, $\times 665$,

Figs. 2 a-b: Planularia mariae Kuznetsova, No. 776807, interval 4920'-4950'.

Fig. 2a: $\times 135$.

Fig. 2 b: Detail of aperture, $\times 665$.

Fig. 3: Reinholdella sp., No. 684303, interval 5090' $-5120^{\prime}$, ventral view, $\times 135$.

Fig. 4: Lenticulina sp. 110, No. 634311, interval 5690' $-5705^{\prime}, \times 135$.

Fig. 5: Saracenaria sp. 3, No. 776805, interval 4920'-4950', apertural view, $\times 100$. 

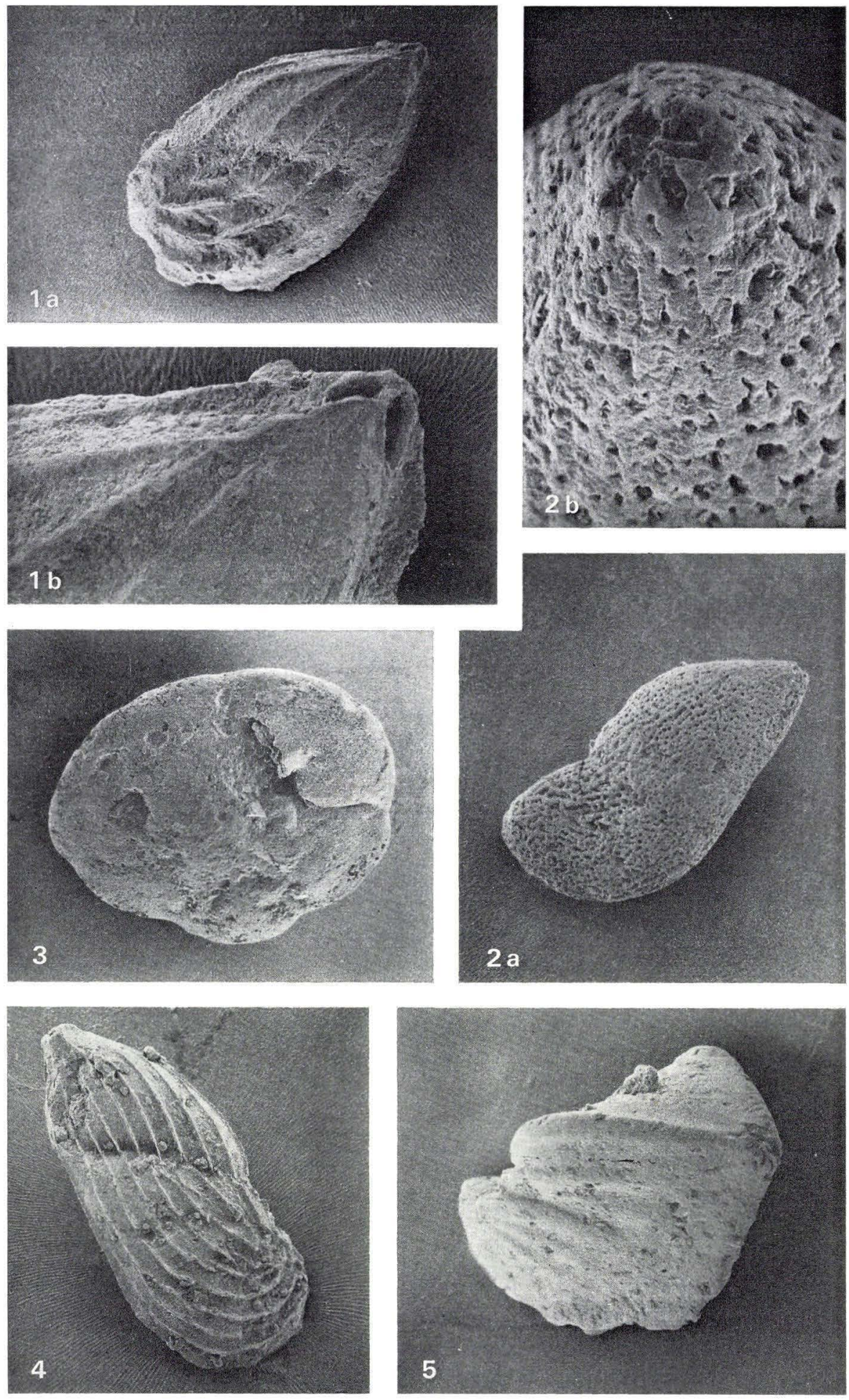


\section{TAVLE 4}

Pliensbachien og øvre sinemurien, Nøvling nr. 1.

Fig. 6: "Bolivina" liasica (TerQ.) form E, nr. 653505, interval 5540'-5570', $\times 200$.

Fig. 7: Geinitzinita pupa (TerQ.), nr. 767110, interval 5510'-5520', × 135.

Fig. 8: G. pupa (Terq.), nr. 796302, interval 5010'-5040', × 135.

Fig. 9: Astacolus speciosus (Terq.), nr. 653608, interval 5540'-5570', $\times 135$.

Fig. 10: Marginulina spinata TerQ., nr. 664701, interval 5570'-5600'.

Fig. 11: Annulina metensis Terq., nr. 705407, interval 5330'-5360', $\times 140$.

Fig. 12: Geinitzinita pupoides (NøRVANG), nr. 666909, interval 5570'-5600', $\times 200$.

Fig. 13: Dentalina varians TerQ., nr. 705412, interval 5330'-5360', $\times 135$.

Fig. 14: D. varians TerQ., nr. 746611, interval 5360'-5390', $\times 200$.

Fig. 15: Geinitzinita subprismatica (FRANKE), nr. 705409, interval 5330'-5390', × 265.

\section{PLATE 4}

Pliensbachian and Upper Sinemurian, Nøvling No. 1.

Fig. 6: "Bolivina" liasica (TERQ.) form E, No. 653505, interval 5540'-5570', ×200.

Fig. 7: Geinitzinita pupa (TERQ.), No. 767110, interval 5510'-5520', ×135.

Fig. 8: G. pupa (TerQ.), No. 796302, interval 5010'-5040', ×135.

Fig. 9: Astacolus speciosus (TerQ.), No. 653608, interval 5540'-5570', $\times 135$.

Fig. 10: Marginulina spinata TerQ., No. 664701, interval 5570'-5600'.

Fig. 11: Annulina mentensis TERQ., No. 705407, interval 5330'-5360', $\times 140$.

Fig. 12: Geinitzinita pupoides (NøRVANG), No. 666909, interval 5570'-5600', $\times 200$.

Fig. 13: Dentalina varians Terq., No. 705412, interval 5330' $-5360^{\prime}, \times 135$.

Fig. 14: D. varians TerQ., No. 746611, interval 5360'-5390', $\times 200$.

Fig. 15: Geinitzinita subprismatica (FRANKE), No. 705409, interval 5330' $-5390^{\prime}, \times 265$. 


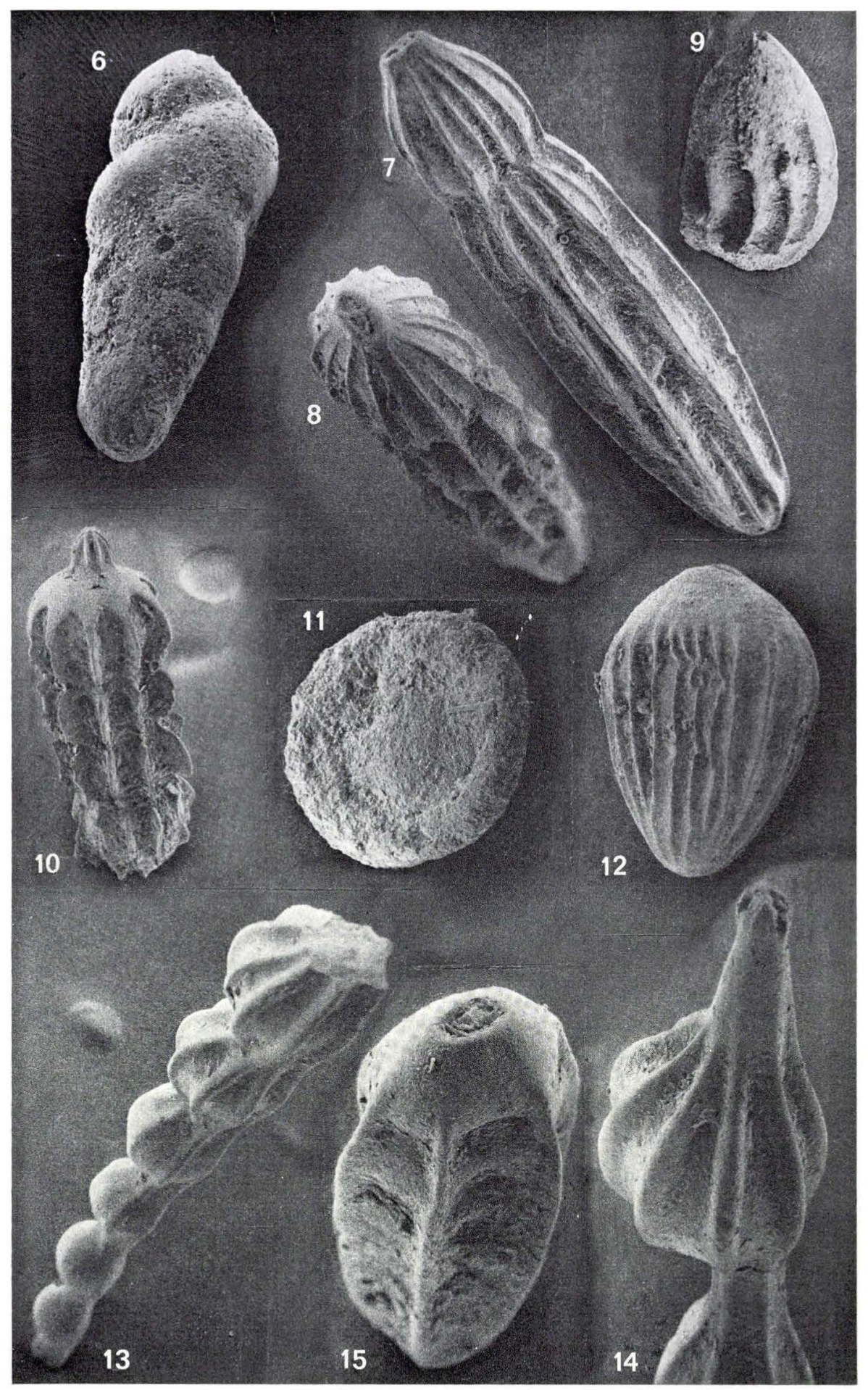




\section{TAVLE 5}

Sinemurien og hettangien, Nøvling nr. 1.

Fig. 16a-b: Lenticulina sp. 26, nr. 623101, interval 5705'-5720'.

Fig. 16a: $\times 135$.

Fig. 16b: Detalje af apertur, $\times 465$.

Fig. 17: Lenticulina sp. 26, nr. 644111, interval 5810'-5840', $\times 135$.

Fig. 18: Astacolus quadricosta (Terquem), nr. 644103, interval 5810'-5840', $\times 135$.

Fig. 19: Geinitzinita substriata (NøRVANG), nr. 644108, interval 5810'-5840', $\times 50$.

Fig. 20: Trochammina nana (BRADY) form A BARTENSTEIN \& BRAND, nr. 634304, interval $5690^{\prime}-5705^{\prime}, \times 135$.

Fig. 21: “Involutina” liassica (JoNes), nr. 566306, interval 5960'-5990', $\times 135$.

Fig. 22: Planularia inaequistriata (Terquem), nr. 566111, interval 5960'-5990', × 125.

\section{PLATE 5}

Sinemurian and Hettangian, Nøvling No. 1.

Figs. 16a-b: Lenticulina sp. 26, No. 623101, interval 5705'-5720'.

Fig. 16a: $\times 135$.

Fig. $16 b$ : Detail of aperture, $\times 465$.

Fig. 17: Lenticulina sp. 26, No. 644111, interval 5810'-5840' $\times 135$.

Fig. 18: Astacolus quadricosta (Terquem), No. 644103, interval 5810' $-5840^{\prime}, \times 135$.

Fig. 19: Geinitzinita substriata (NøRVANG), No. 644108, interval 5810' $-5840^{\prime}, \times 50$.

Fig. 20: Trochammina nana (BRADY) form A BARTENSTEIN \& BRAND, No. 634304, interval $5690^{\prime}-5705^{\prime}, \times 135$.

Fig. 21: "Involutina" liassica (Jones), No. 566306, interval 5960'-5990', 135 .

Fig. 22: Planularia inaequistriata (TERQUem), No. 566111, interval 5960'-5990', ×125. 
D.G.U. III. Række. Nr. 40. I. BANG
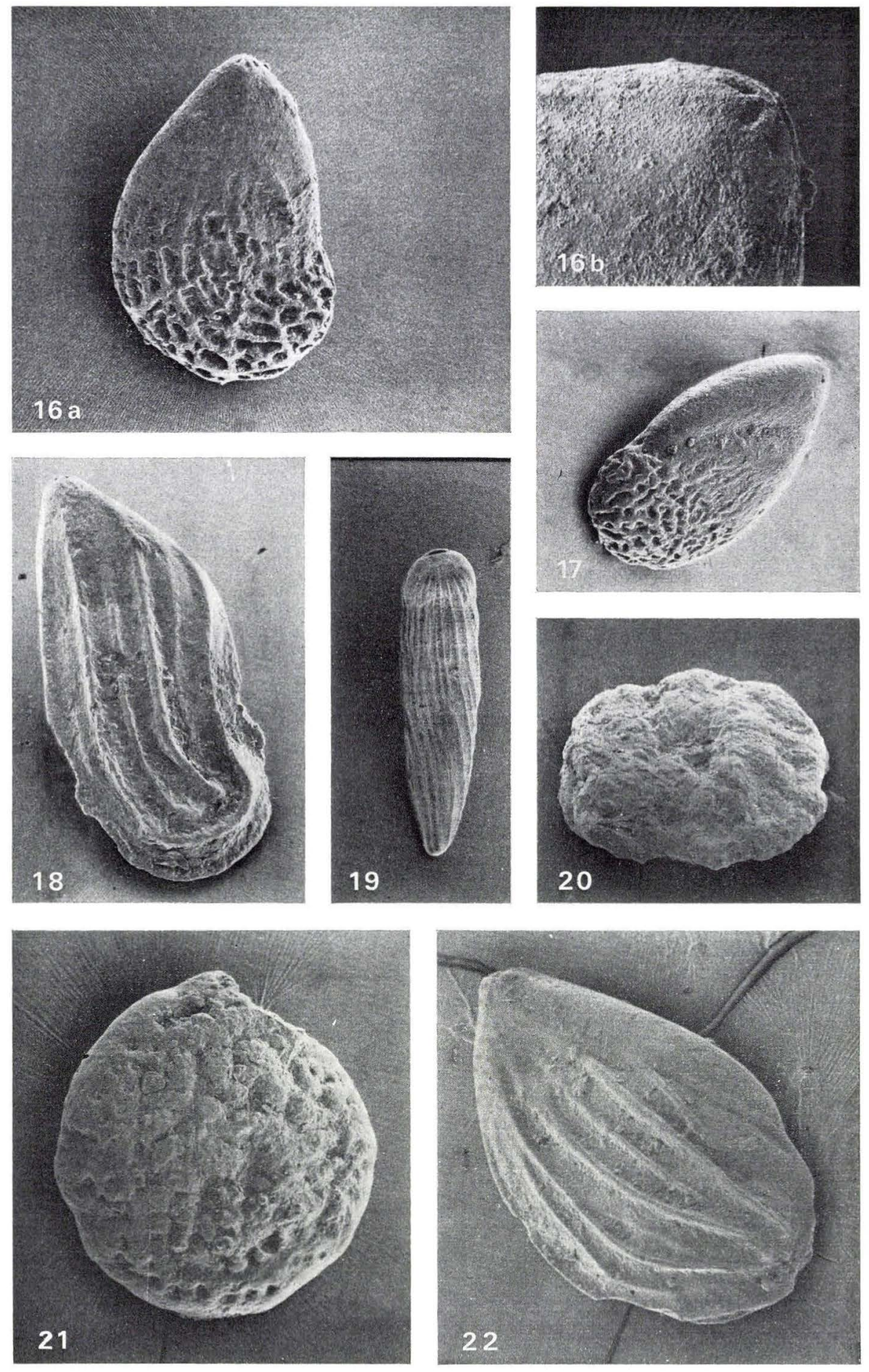
Siluriske bjergarter, Nøvling nr. 1

Fig. 1-2: 14' under toppen af borekærne $3\left(11896^{\prime}-11932^{\prime}\right)$.

Strukturer i starkt lerede siltsten.

$\frac{2}{5}$ naturlig størrelse.

Fig. 3: 20' under toppen af borekærne $3\left(11896^{\prime}-11932^{\prime}\right)$.

Kalksten med indhold af lerstenslegemer og fossiler. $\frac{3}{5}$ naturlig størrelse.

Foto: O. NeErgaArd Rasmussen.

\section{PLATE 6}

Silurian rocks, Nøvling No. 1

Figs. 1-2: 14' below the top of core No. 3 (11896'-11932').

Structures in highly clayey siltstone.

$\frac{2}{5}$ natural size.

Fig. 3: $20^{\prime}$ below the top of core No. $3\left(11896^{\prime}-11932^{\prime}\right)$.

Limestone with claystone-inclusions and fossils.

$\frac{3}{5}$ natural size.

Phot. O. Neergatad Rasmussen. 
D.G.U. III. Række. Nr. 40. O. BRUUN CHRISTENSEN

Tavle 6
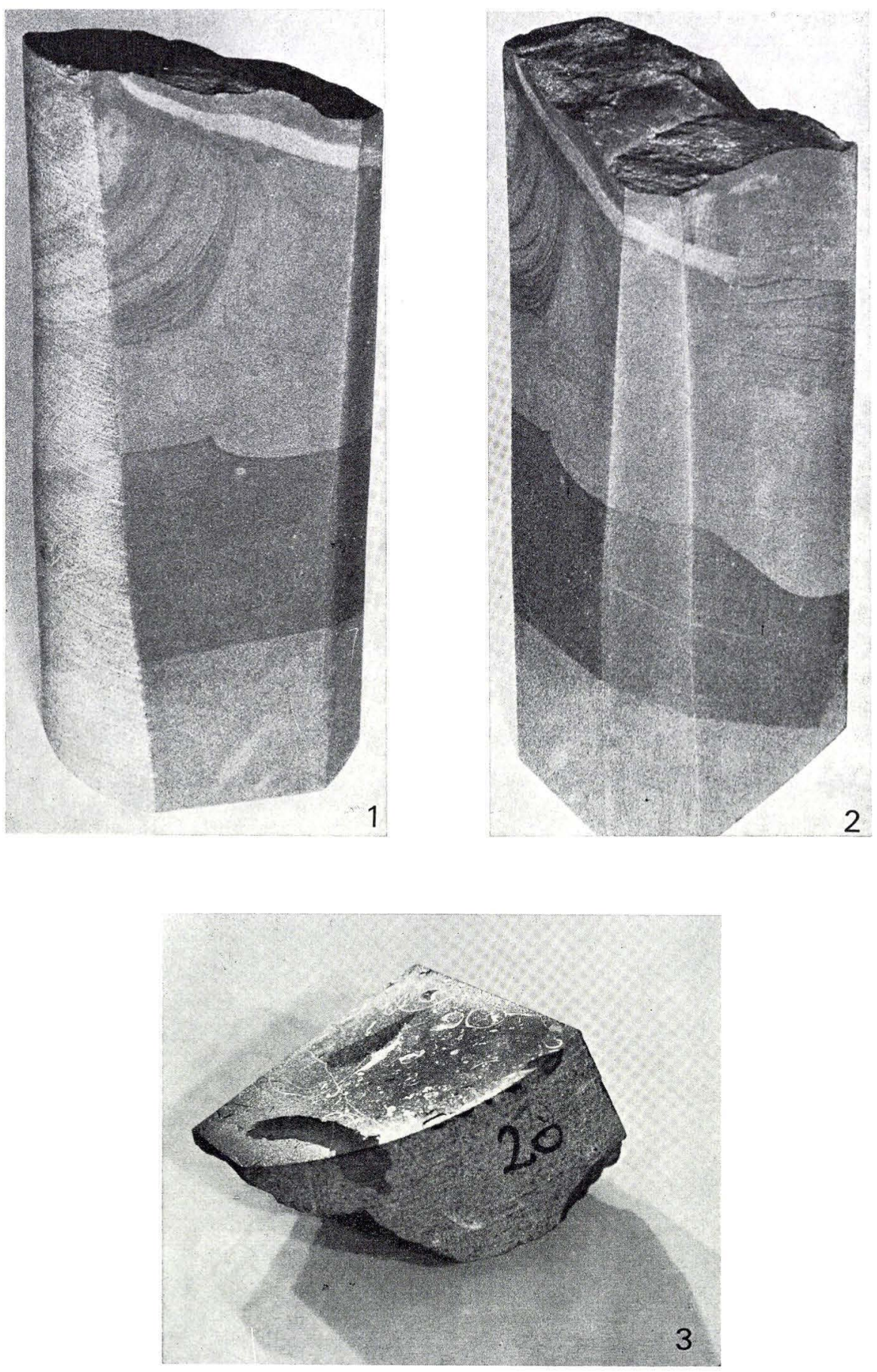
Siluriske bjergarter, Nøvling nr. 1

Fig. 1: 46' under toppen af borekærne $1\left(11555^{\prime}-11612^{\prime}\right)$.

Strukturer i grålige og olivengrønne, stærk kalkholdige lersten. Naturlig størrelse.

Fig. 2: 22' under toppen af borekærne $3\left(11896^{\prime}-11932^{\prime}\right)$.

Strukturer i lersten med kalkstensslirer. Svag ætset overflade. Næsten naturlig størrelse.

Foto: O. NeErgaArd Rasmussen.

\section{PLATE 7}

Silurian rocks, Nøvling No. 1

Fig. 1: 46' below the top of core No. $1\left(11555^{\prime}-11612^{\prime}\right)$.

Structures in greyish and olive-green, highly calcareous claystone.

Natural size.

Fig. 2: 22' below the top of core No. 3 (11896'-11932').

Structures in claystone with limestone schlieren. Slightly etched surface.

Almost natural size.

Phot. O. Neergaard Rasmussen. 

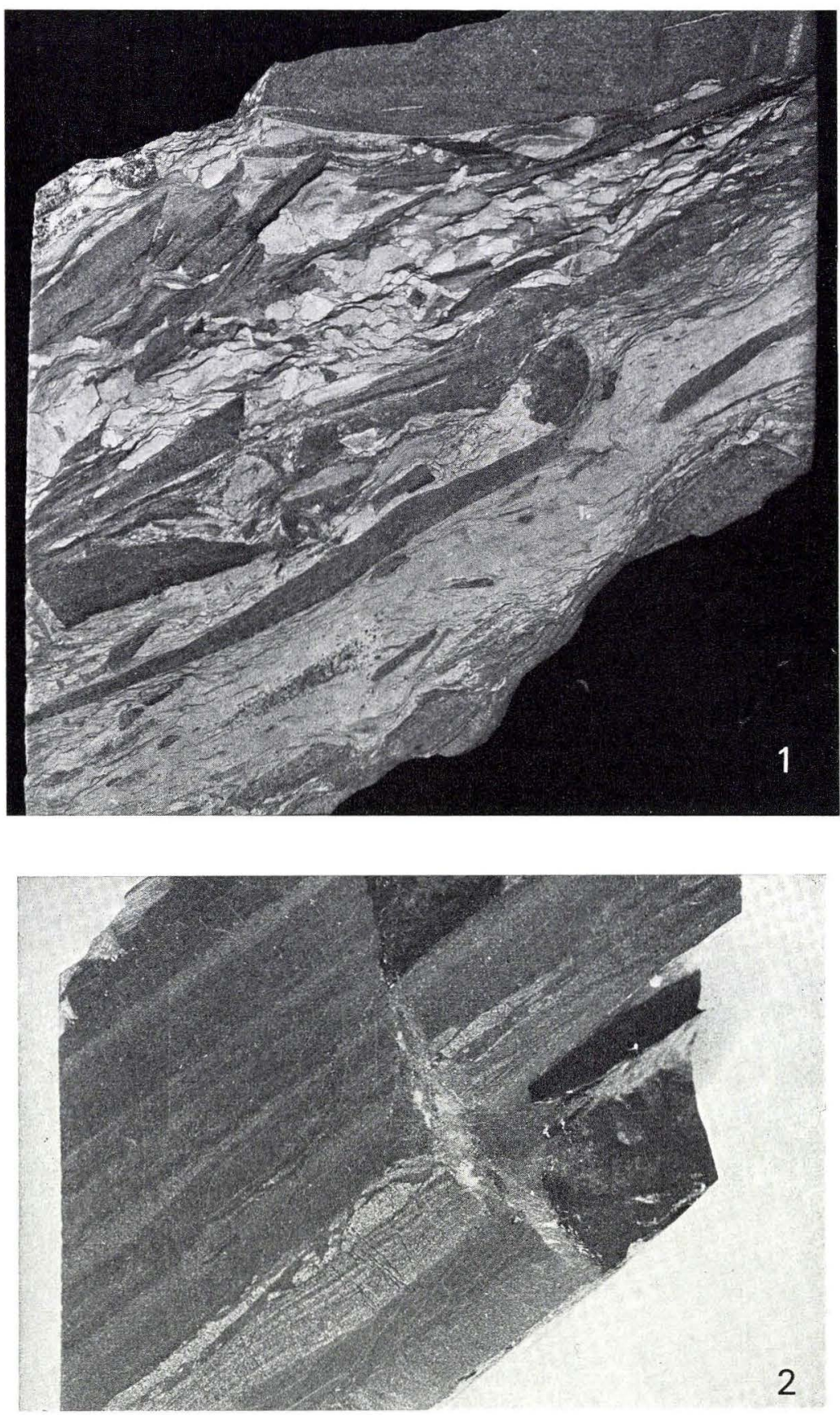
TAVLE 8

$\times 50$

Siluriske conodonter, Nøvling nr. 1

D.G.U.

Fig. 1: Plectospathodus extensus R HODEs 1953

Katalog nr.

Fig. 2, 4: Hindeodella equidentata RHodes $1953 \ldots \ldots \ldots \ldots \ldots \ldots$

1972-TJH-1

Fig. 3: Spathognathodus?sp...

1972-TJH-2

Fig. 5: Lonchodina? greilingi WALLISER 1957

1972-TJH-3

Fig. 6

Ozarcodina sp.

1972-TJH-4

Fig. 7: Distomodus?sp.

1972-TJH-5

Fig. 8: Lonchodina aff. walliseri ZIEGLER 1960.

Foto: Chr. WestergaARD

\section{PLATE 8}

$\times 50$

D.G.U

Silurian conodonts, Nøvling No. 1

Catalogue No.

Fig. 1: Plectospathodus extensus RHOdEs 1953

Figs. 2, 4: Hindeodella equidentata RHODEs 1953

Fig. 3: Spathognathodus? sp...

1972-TJH-3

Fig. 5: Lonchodina ? greilingi WALLISER 1957

Fig. 6: Ozarcodina $s p$

Fig. 7

Fig. 8: Lonchodina aff. walliseri ZIEGLER 1960

1972-TJH-7

Phot. Chr. WestergaArd. 

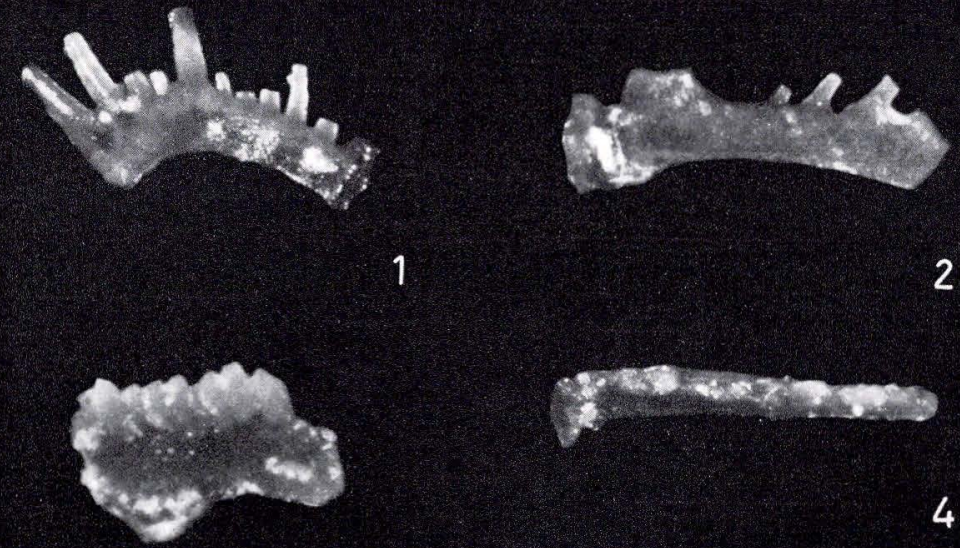

3
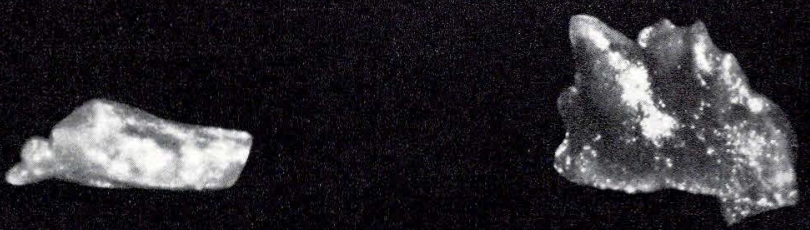

5
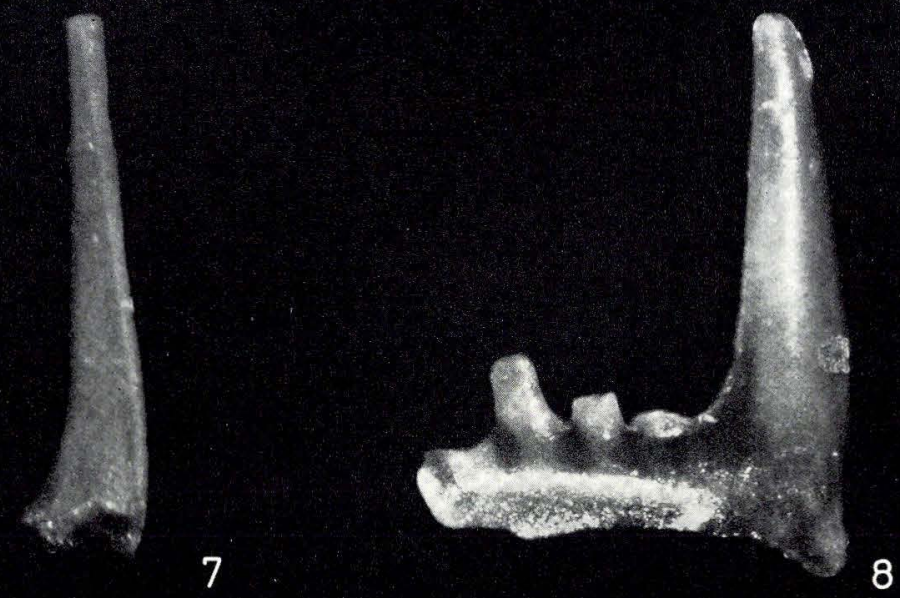
Bilag til D. G. U. III. Række . Nr. 40

NøVLING NR. 1

UDFØRT AF DANSK UNDERGRUNDS CONSORTIUM 1966 D. G. U. ARKIV NR. 84.1777

\begin{tabular}{|c|c|c|c|c|c|c|}
\hline \multicolumn{2}{|c|}{$\begin{array}{l}\text { DYBDER I METER } \\
\text { Depths in metres } \\
\end{array}$} & \multirow{2}{*}{\multicolumn{2}{|c|}{ 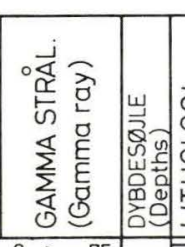 }} & \multirow{2}{*}{ 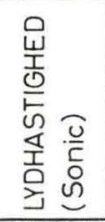 } & \multirow{2}{*}{ 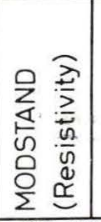 } & \multirow{2}{*}{$\begin{array}{l}\text { CHRONOSTRATIGR } \\
\text { Chronostratigraph }\end{array}$} \\
\hline $\begin{array}{l}\text { KOTER } \\
\text { (Belou } \\
\text { sea } \\
\text { level) }\end{array}$ & \begin{tabular}{|l} 
UNDER KB \\
(Below \\
Kelly \\
Bushing \\
Busting
\end{tabular} & & 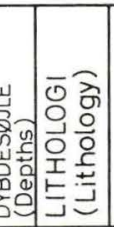 & & & \\
\hline
\end{tabular}

$+51-18-0$ - ${ }^{5}-$ KVARTER OG TERTIER (OUAT.\& TERT)

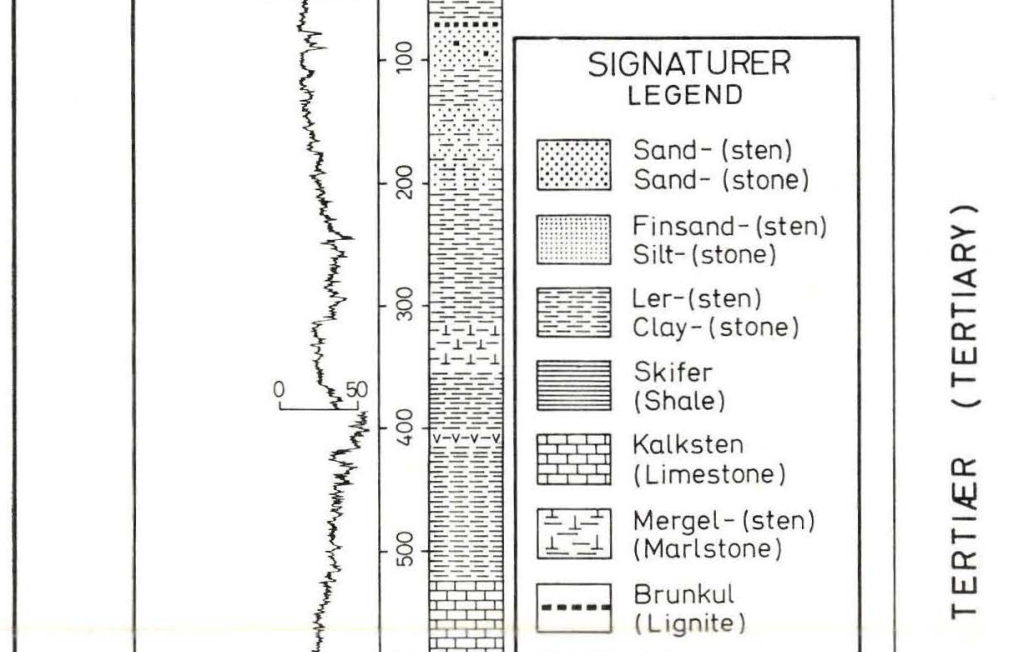

-571 640 D
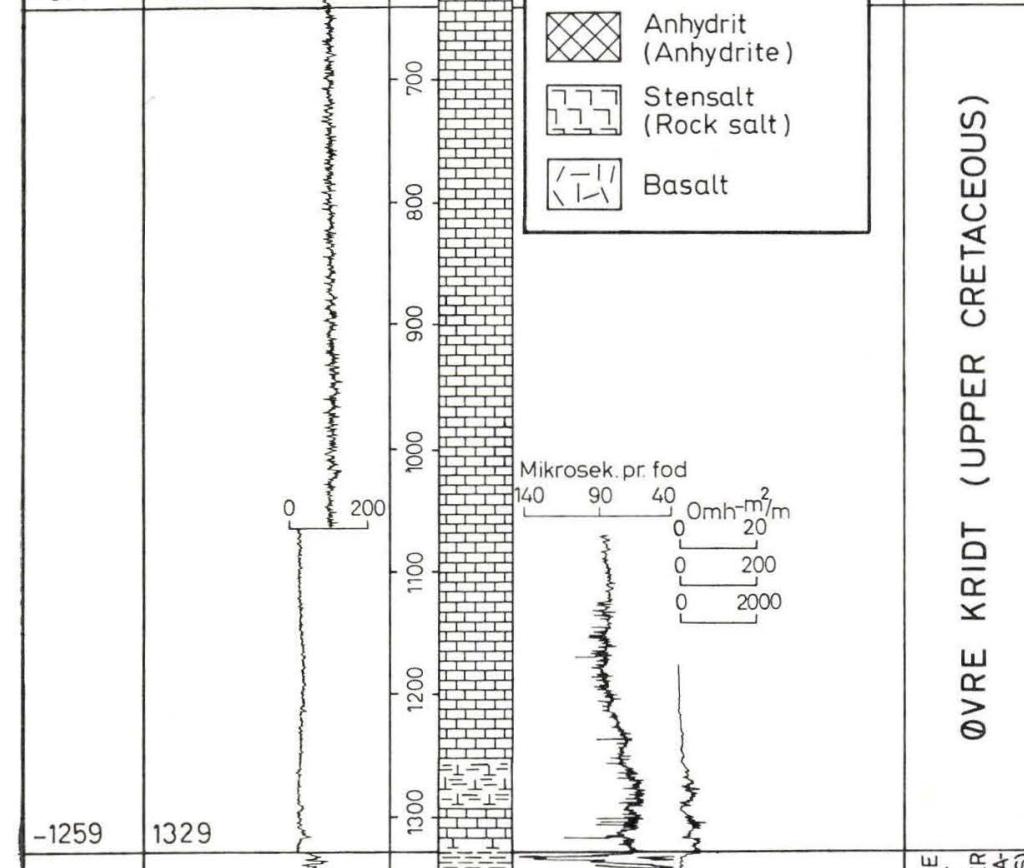

\begin{tabular}{l|l|l}
-1324 & 1394 \\
\hline
\end{tabular}

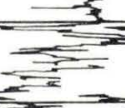

$-1398 \quad 1468$

$\frac{3}{3}$

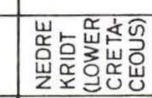

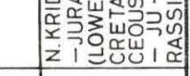
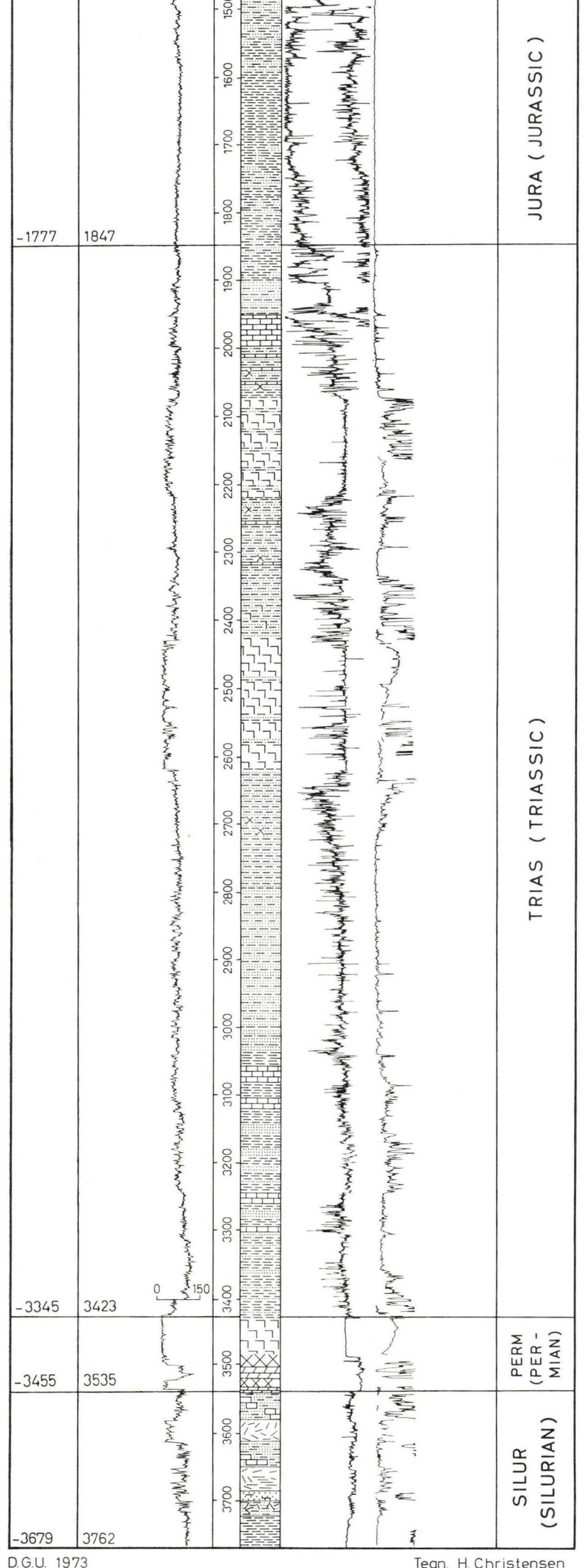